\title{
BIOLOGICAL CONTROL OF Marmara gulosa GUILLÉN AND DAVIS IN THE SAN JOAQUIN VALLEY
}

\author{
A Thesis \\ Presented to the Faculty of \\ California Polytechnic State University \\ San Luis Obispo
}

In Partial Fulfillment

of the Requirements for the Degree of

Master of Science in Agriculture, with Specialization in Crop Science

by

Crystal Allina Kirkland

February 2009 
(C) 2009

Crystal Allina Kirkland ALL RIGHTS RESERVED 


\section{COMMITTEE MEMBERSHIP}

TITLE:

Biological control of Marmara gulosa Guillén and Davis in the San Joaquin Valley

AUTHOR:

Crystal Allina Kirkland

DATE SUBMITTED:

February 2009

COMMITTEE CHAIR:

Dr. David H. Headrick, Ph.D.

COMMITTEE MEMBER: Dr. Michael Costello, Ph.D.

COMMITTEE MEMBER: $\quad$ Dr. Lauren C. Garner, Ph.D. 


\begin{abstract}
Biological control of Marmara gulosa Guillén and Davis in the San Joaquin Valley
\end{abstract}

Crystal Allina Kirkland

Peelminer, Marmara gulosa Davis and Guillén, has been reported as a sporadic pest in California and Arizona since 1998. Marmara gulosa has been a persistent pest in the San Joaquin Valley of California (USA) since 1998. Prior to 2000 the only reports of high populations of citrus peelminer were in the Coachella Valley. The larval stages of M. gulosa create serpentine mines scarring the upper epidermal layers of citrus rind, rendering it unacceptable for fresh market sale.

Chemicals have failed to provide adequate control of M. gulosa; thus, the use of natural enemies is considered the best long-term option. Cirrospilus coachellae Gates (Eulophidae: Eulophinae) is an effective gregarious parasite of peelminer in the Coachella Valley; however, attempts to establish this species in the San Joaquin Valley have so far been unsuccessful. Other natural enemies may be necessary to control peelminer in this region. The discovery of populations of the tetrastichine eulophid Hadrotrichodes waukheon LaSalle parasitizing M. gulosa in the San JoaquinValley indicates a possible option for biological control of this pest.

Hadrotrichodes waukheon (Hymenoptera: Eulophidae: Tetrastichinae) is a parasite of M. gulosa. Newly discovered morphological variations within the species are reported, including the first description of the male. New biological information including preferred life stage of host for parasitism, clutch sizes, male to female ratios and meconial positioning are included. Field studies demonstrated that one to four adult $H$. waukheon could emerge from a single M. gulosa larva, and later instar M. gulosa larvae were preferred. Hadrotrichodes waukheon is a gregarious, primary parasitoid and may be a candidate agent for biological control of $M$. gulosa. 


\section{ACKNOWLEDGMENTS}

Thank you to the Citrus Research Board for partial funding of this project. I would like to extend a very special thank you to everyone who helped me through completion of this thesis. 


\section{TABLE OF CONTENTS}

List of Tables $\quad$ vii

List of Figures viii

Introduction $\quad 1$

Materials and Methods $\quad 17$

$\begin{array}{ll}\text { Results } & 26\end{array}$

$\begin{array}{ll}\text { Discussion } & 48\end{array}$

$\begin{array}{ll}\text { Conclusions } & 71\end{array}$

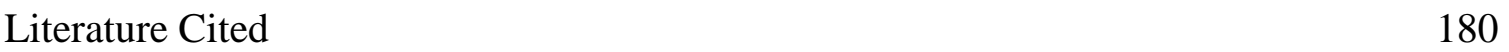


Table

\section{LIST OF TABLES}

1. Parasitoid collection data compared to rearing data: Parasitoid collection data includes collection date, emergence date, sex of the parasitoid found and clutches from BFE associated with parasitoid information from the growth and development survey conducted at BFE in 2004 including collection date, bush number sampled, the larval stage parasitized and the number of larvae on each branch.

Page

2. Total number of parasitoids found and total number of M. gulosa larvae found on each bush on all the combined sample dates during the growth and development survey at BFE in 2004.

3. Parasitoids reared from Stewart's associated with parasitoids found in the survey conducted at Stewart's in 2004: Parasitoid collection data includes collection date, emergence date, sex of the parasitoid found and clutches from the Stewart's Residence associated with parasitoid information from the growth and development survey conducted at the Stewart's in 2004 including collection date, the bush number sampled, the larval stage parasitized and the number of larvae on each branch.

4. Clutch sizes and sexes within clutches of Hadrotrichodes waukheon at BFE and Stewart's on oleander in 2004.

5. Total number of male and female Hadrotrichodes waukheon and quantity in each specific clutch size from BFE and Stewart's oleander in 2004.

6. Eulophids genera occurring in California

10. The genus of parasitoids with mining hosts in addition to Lepidoptera, the hosts they are found on, and the number of species within each genus. lepidopteran hosts. 
Figure

\section{List of Figures}

1. Valley Locations in CA 1

2. Marmara gulosa damage on citrus fruit and shoots. $\quad 8$

3. Marmara gulosa adult 10

4. Cirrospilus coachellae Gates 19

5. Glass vial taped to a branch for the release of Cirrospilus coachellae 20

6. Hadrotrichodes waukheon male $\quad 27$

7. Growth and development of M. gulosa on BFE oleander in 2004.

8. Stages of M. gulosa parasitized on BFE oleander in 2004.

9. Percent parasitism of $M$. gulosa by $H$. waukheon by collection date at 31 BFE in 2004

10. Growth and development of M. gulosa on Stewart's oleander in 2004

11. Stages of M. gulosa parasitized on BFE oleander in 2004.

12. Percent parasitism of $M$. gulosa by $H$. waukheon by collection date at 34 Stewart's oleander in 2004

13. Quantities of male and female Hadrotrichodes waukheon reared from oleander by emergence date at BFE in 2004.

14. Quantities of male and female Hadrotrichodes waukheon reared from oleander by collection date at BFE in 2004.

15. Quantities of male and female Hadrotrichodes waukheon reared from oleander by emergence date at Stewart's in 2004.

16. Quantities of male and female Hadrotrichodes waukheon reared from oleander by collection date at Stewart's in 2004.

17. Hadrotrichodes waukheon meconial pellet arrangement

18. Average high temperatures from March through December for 2003, 2004 and 2005 at the Lindcove Field Station. 


\section{Introduction}

\section{$\underline{\text { Importance of Marmara gulosa as a Pest }}$}

Peelminer, Marmara gulosa Davis and Guillén, (Lepidoptera: Gracillariidae) was first reported on citrus in California in 1917 (Vinal 1917) and has been reported as a sporadic pest in California and Arizona in 1933 (Lockwood), 1948 (Wolgum), 1955 (Atkins 1961), 1960 (Anonymous), and 1969-70 (Atkins 1971). In 1999 peelminer was found in the southern San Joaquin Valley, Kern Co., CA (Fig. 1) (Jutzi 1998) and reached high population levels in 2000 (Neff 2002). Infestations were reported as far north as Fresno Co., CA (Kris Godfrey, entomologist, CDFA, pers. comm. 2002). Prior to 2000 the only reports of high populations of citrus peelminer were in the Coachella Valley (Fig. 1) in 1984-85 and 1994-95 (Guillén et al. 2001and Reeves 1995).

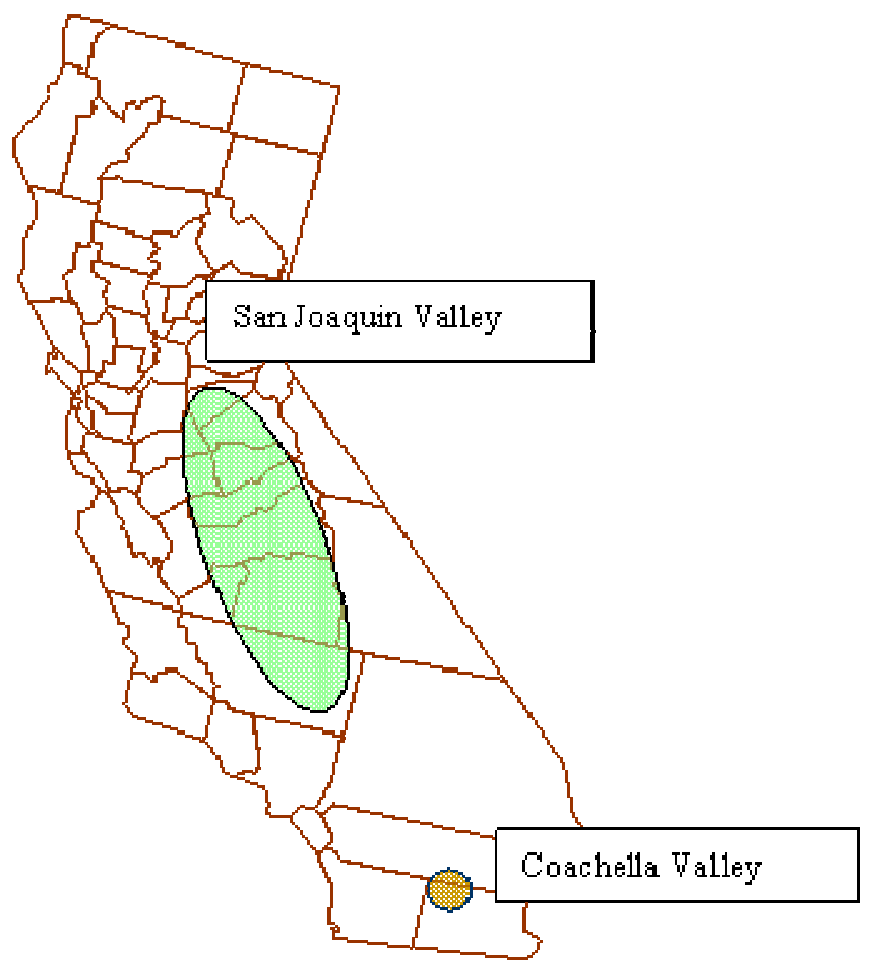

Figure 1. Valley locations in California 
Peelminer damage has resulted in considerable economic losses to growers. Two or more mines render the fruit unacceptable for fresh market sale (Grafton-Cardwell, UCKAC, pers. comm. 2002; K. Godfrey, entomologist, CDFA, pers. comm. 2002; J. Stewart, Pest Management \& Associates, pers. comm. 2002; J. Stewart-Leslie, Pest Management \& Associates, pers. comm. 2002). Another commodity of concern is grapes. Mining damage on the fruit of grape vines can lead to secondary infections such as bunch rot, Botrytis cineria (James Stewart, Pest Management Associates, Exeter, Ca. pers. comm. 2001). Excessive mining on new vegetative growth can form open wounds leading to sap secretion and possibly secondary infection at the site of injury (Dennis Haines 2001 pers. comm.). Prior to 2001 it was thought that Marmara salictella Clemens was the species causing damage to citrus, but in 2001 the pest populations on citrus were identified and described as a new species, Marmara gulosa (Guillén 1999 and Guillén et al. 2001). Since 2001 verification that $M$. gulosa is the species of Marmara causing damage in California, Arizona, and Mexico has been confirmed (Guillén et al. 2001; GraftonCardwell, pers. comm. 2002; Headrick and Finch, unpublished data).

The species name gulosa stems from the Latin word for glutton, which is appropriate since M. gulosa has a host list of over twenty-eight different families of plants (Grafton-Cardwell, pers. comm. 2002; Neff 2002; Spiedel 2004). Some host plant species include: grapefruit (Citrus paradis Macfadyen), lemon (Citrus limon Burmann), tangerine (Citrus reticulata Blanco), lime (Citrus aurantifolia Tanaka), orange (Citrus sinensis Osbeck), nectarine (Prunus persica var. nucipersica L.), grape (Vitis vinifera L.), olive (Olea europaea L.), walnut (Juglans spp. L.), cotton (Gossypium hirsutum L.), oleander (Nerium spp. L.), willow (Salix spp. L.), avocado (Persea americana Mill), 
some squash (Family Cucurbitaceae Juss), and some peppers (Capsicum annum L.)

(Atkins 1961; Atkins 1971; Guillén 1999; Guillén et al. 2001; Grafton-Cardwell, pers. comm. 2002; Neff 2002). Many citrus varieties have been observed to be hosts for $M$. gulosa, but $M$. gulosa is especially active on pummelos, grapefruit, and certain varieties of navels (Reeves 1995; Guillén 1999; Guillén et al. 2001; Grafton-Cardwell pers. comm. 2002). Navel varieties that appear preferred by M. gulosa include Fukumoto, Thompson Improved, Powell, Atwood, Barnfield, and Lane Late (Grafton-Cardwell pers. comm. 2002).

\section{$\underline{\text { Taxonomy and Pest History of Marmara gulosa }}$}

Marmara salictella was described by J. B. Clemens in 1863. Clemens (1863) found the miner feeding on new growth of yellow willow (Salix lutea Nuttall) in the eastern United States. The first record of mining by a similar species to M. salictella on citrus in southern California was reported by Vinal (1917). From 1917 to the present, peelminer, assumed to be M. gulosa, has been recorded on citrus (Vinal 1917; Lockwood 1933; Wolgum 1948; Anonymous 1960; Atkins 1961, 1971; Reeves 1995; Gibson et al. 1997). The miner in these reports was listed as M. salictella and is currently believed to be misidentified following Guillén's findings in 1999. Guillén (2001) found that external features between Marmara salictella and the newly described species were relatively similar; however, inspection of the male genitalia provided characteristics for separation of M. gulosa from M. salictella.

Historical accounts consider M. gulosa damage to be extensive in many citrus groves in southern California and Arizona. In 1960, a $0.2 \mathrm{~km}^{2}$ grove of grapefruit in Indio had 20-36\% of trees with M. gulosa damage on the fruit (Atkins 1961 and 
Anonymous 1960). Grapefruit groves totaling $0.4 \mathrm{~km}^{2}$ in the Coachella Valley had $M$. gulosa damage on the fruit in 1960. Ruby Red grapefruit (Citrus paradis Macfayden) trees sustained the worst infestations, but also had a 4.6-7.6 m oleander hedge on both sides of the grove. Oleander serves as an alternate host for M. gulosa. Even with high infestations of M. gulosa on grapefruit, the Cooperative Economic Insect Report determined M. salictella, probably M. gulosa, actually preferred oleander to grapefruit as a host plant (Atkins 1961 and Anonymous 1960). In Blythe, Riverside Co., CA 1.2 km² of Marsh grapefruit, $0.1 \mathrm{~km}^{2}$ of Valencia oranges, $0.1 \mathrm{~km}^{2}$ of tangerines, and a few newly planted lemons had heavy mining in 1969 and 1970. These lemons had peelminer damage on the new shoots, and the other citrus varieties had mining on the fruit and the shoots (Atkins 1971). In 1969 and 1970 Imperial Co. had reports of peelminer on lemon shoots and fruit as well as on cotton bolls. The Coachella Valley had $0.8 \mathrm{~km}^{2}$ of Ruby Red grapefruit infested with peelminer on the fruit and the shoots in 1969 and 1970 (Atkins 1971). Yuma and Phoenix, AZ had over $4.1 \mathrm{~km}^{2}$ of reported infestations in 1969 and 1970 (Atkins 1971).

The only report of parasitism was by Atkins (1961), who observed a single primary parasite and a single hyperparasite attacking a Marmara larva in Indio, Riverside Co., CA. The primary parasite, found in the fall, was determined to be an ectoparasite and a member of the superfamily Chalcidoidea (Hymenoptera). From the single observation, Atkins (1961) determined that primary parasites parasitized fifth instar larvae. The hyperparasite was reported as parasitizing the pupae of the primary parasite. The identity of the two parasites was not determined. 


\section{Marmara gulosa in the San Joaquin Valley (SJV) 1999 to present}

In 1998, M. gulosa was discovered attacking citrus in Kern Co., CA (Jutzi 1998)

and Tulare Co., CA (D. Haines 2002 personal communication) of the San Joaquin Valley and has since been consistently aggressive in feeding on citrus and other commodities in these areas (Godfrey et al. 2003). During the 2000 field season, citrus peelminer was found on all citrus varieties throughout the San Joaquin Valley and some orchards had infestations as high as $70 \%$ of the fruit (Grafton-Cardwell et al. 2003). This thesis is not engaging the causes associated with the change in $M$. gulosa pest status in the San Joaquin Valley in 1999/2000; some ideas regarding the causes included a series of events related to the CA freeze event of 1998 (Gudgel 1999). In response to a fruit shortage, shipments of citrus fruit were brought from two locations in northern Mexico, La Ciudad de Constitucion, Baja, Mexico (MX) and Hermosillo, Sonora, MX, into Tulare Co. and perhaps Kern Co., CA packinghouses to maintain processing. The following year $M$. gulosa infestations in nearby citrus were noted in a Pest Damage Report (PDR) logged for Tulare Co., Dec 1999 oranges. There is no definitive cause and effect, but the correlation was readily accepted by both the research and grower communities.

Marmara gulosa infestations were clearly documented as appearing to spread rapidly in the San Joaquin Valley, being reported as far as Fresno Co. by the end of 2000 (D. Haines 2002 personal communication). An increase in the number of host plants used for development by citrus peelminer also was noted (Godfrey et al. 2003). In the fall of 2000, citrus peelminer was found on walnut husks, Juglans spp. (Juglandaceae). In the spring of 2001, it was observed on table grapes (Vitis vinifera L., 'Thomson 
seedless' and 'Flame'), mining the berries, petioles and canes, and occasionally in dark, firm plums, Prunus domestica L., (Rosaceae) (D. Haines 2002 personal communication).

Attributing pesticide upset, especially the use of insect growth regulators, as the cause of recent, sustained, economically damaging levels of M. gulosa in the San Joaquin Valley has been shown to be unlikely (Grafton-Cardwell et al. 2006). The differential reduction in natural enemy activity that could lead to increases in pest species densities was demonstrated with Rodolia cardinalis (Mulsant) (Coleoptera: Coccinellidae), the predator of cottony cushion scale, Icerya purchasi Maskell (Homoptera: Margarodidae), but not with parasitoid wasps of other pest species in citrus (Ishaaya et al. 1992, Mendel et al. 1994, Grafton-Cardwell et al. 2003, Grafton-Cardwell et al. 2006). There remains no clear evidence however, to pinpoint a cause for the change in pest status of M. gulosa thoughout its recorded history in southern California and the San Joaquin Valley.

\section{$\underline{\text { Management Research }}$}

Chemical. - Pesticide trials have been conducted in California and Arizona for chemical control of Marmara populations in citrus. Pesticide trials were conducted in 1969 and 1970 by Atkins in two blocks of grapefruit in Blythe, Riverside Co., CA (Atkins 1971). "Block B" was sprayed 30 days after "Block A," and both were sprayed with the same organophosphate. The grapefruit inspected in Block A had $15.4 \%$ of the fruit with Marmara damage and block B had $37.5 \%$ of the fruit with M. salictella, probably $M$. gulosa, damage. The results were interpreted as indicating early season spraying to be more effective. The same two blocks of grapefruit were used for pesticide trials in 1970. Trials using several organophosphates and carbamates were conducted. 
All treatments had no significant difference although the early treatments were interpreted as being more effective than the late treatments (Atkins 1971).

Pesticide efficacy trials were conducted between 2001 and 2007 in the San Joaquin Valley. Registered and experimental-use toxins were used, including organophosphates, neonicotinoids, pyrethroids, insect growth regulators, and other insecticides (Grafton-Cardwell and Reagan 2001, 2004, 2006, Grafton-Cardwell et al. 2003, Grafton-Cardwell 2005, Grafton-Cardwell et al. 2007). Most insecticide classes provided good larval control in the laboratory. However, control was much less effective in field trials; poor application coverage was deemed a likely factor as most M. gulosa were mining on the trunk-side of fruit, inside the canopy low to the ground (GraftonCardwell et al. 2003).

Field trials using diflubenzuron, a chitinase inhibitor that sterilizes insect eggs (Amalin et al. 2004), in the Micromite 80WG formulation, in 2005 indicated that multiple applications reduced the overall percentage of mined fruit (Grafton-Cardwell et al. 2005). Reduction in mining was correlated with an increased number of applications.

Biological Control Program. - Marmara gulosa is considered native to the southwestern United States (Guillén et al. 2001), but the original species description did not include Mexico in its distribution. A biological control program was initiated for $M$. gulosa in the San Joaquin Valley with the intention of moving candidate natural enemy species from southern CA and while simultaneously prospecting in Sonora, MX for natural enemies. Sonora was chosen for foreign exploration due to the purported importation of infested fruit from that area. 


\section{Biology}

Marmara gulosa larvae feed in the upper epidermal layers of the rinds of citrus fruit and sucker growth causing silvery white serpentine surface mines (Fig. 2) (Atkins 1961; Atkins 1971; Guillén 1999; Guillén et al. 2001).

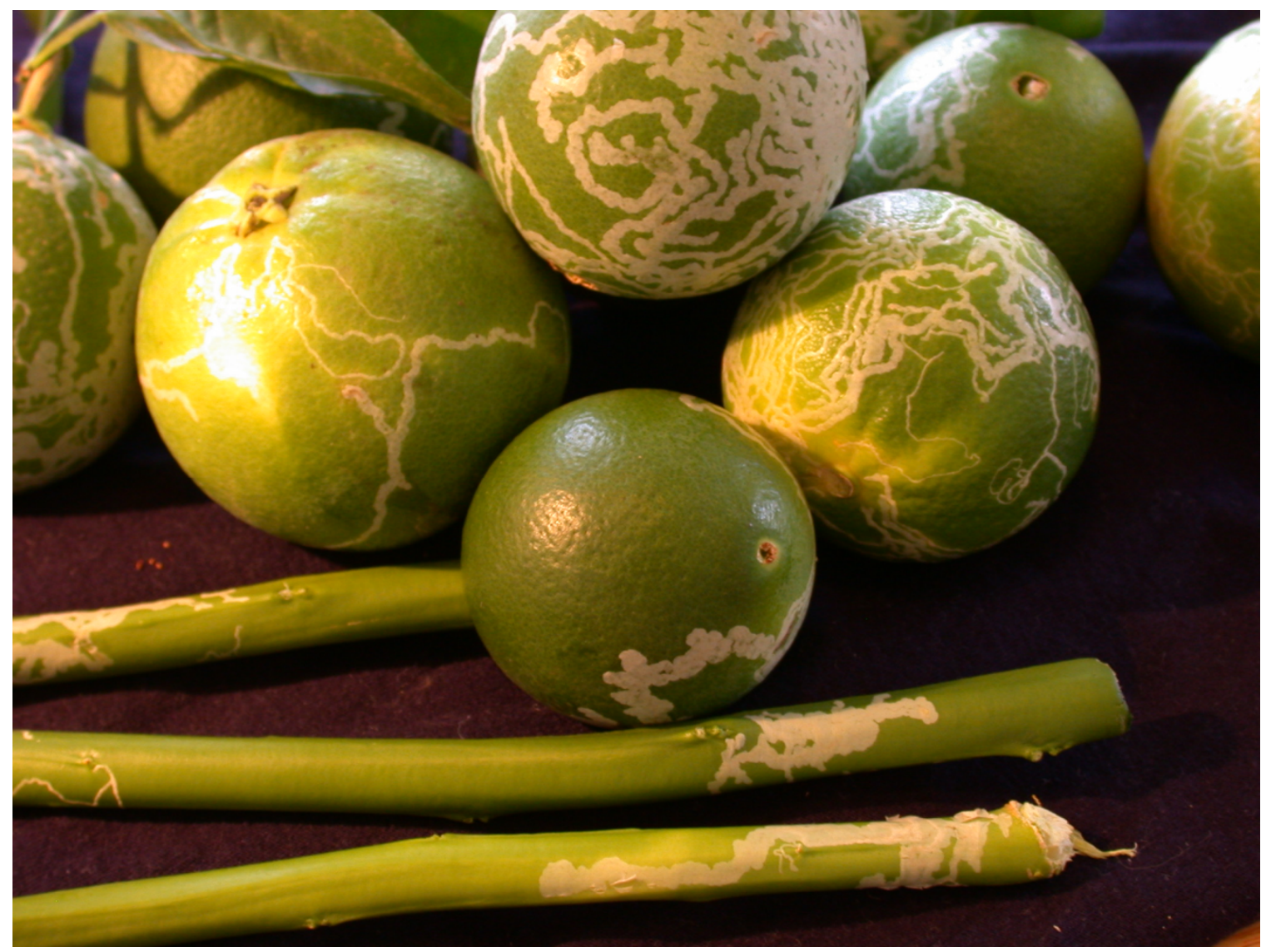

Figure 2. Marmara gulosa damage on citrus fruit and shoots.

The damage is purely aesthetic, but two or more mines will usually render the fruit unacceptable for fresh market (Guillén 1999). Since fresh market fruit usually attains a higher market price, this damage represents a significant economic loss to the grower. Mining creates a thin layer of epidermis that provides a protective barrier for the developing larva. Feeding on suckers of citrus trees has no known economic impact (Atkins 1971; Guillén 1999; Guillén et al. 2001). 
Marmara gulosa produces five to seven generations per year (Guillén 1999 and Guillén et al. 2001). A female lays one to eight eggs on the fruit surface, and a single female can lay ten to fifty eggs in her lifetime (Guillén 1999 and Guillén et al. 2001). Larvae emerge from the egg, burrow into the fruit's epidermis, and feed under the protection of the epidermis. Growth and development trials in the laboratory show one larva can go through five to seven instars, and the development time from egg to adult is about two to four weeks depending on temperature (Guillén 1999; Guillén et al. 2001; Neff 2002). In the penultimate instar, the larva ceases feeding. The larval integument becomes pink and the feeding mouthparts are shed. The feeding mouthparts are replaced by mouthparts used for spinning silk (Guillén 1999 and Guillén et al. 2001). The larva then finds a protected area on the fruit, in the fold of a leaf, or in the soil, and spins a cocoon for pupation (Guillén 1999 and Guillén et al. 2001). The larva additionally creates small silken balls, cuts a small hole in the cocoon, pushes the balls out, attaching them to the outside, and closes up the hole (Guillén 1999 and Guillén et al. 2001). The larva will attach ten to eighteen balls in this fashion (Grafton-Cardwell et al. 2008). The reason for attachment of the silk balls is unknown (Grafton-Cardwell et al. 2008). The adult moth is approximately two millimeters long (Guillén 1999 and Guillén et al. 2001). M. gulosa adults are dark gray in color with a few light gray bands running across the wings (Fig. 3) (Guillén 1999 and Guillén et al. 2001). 


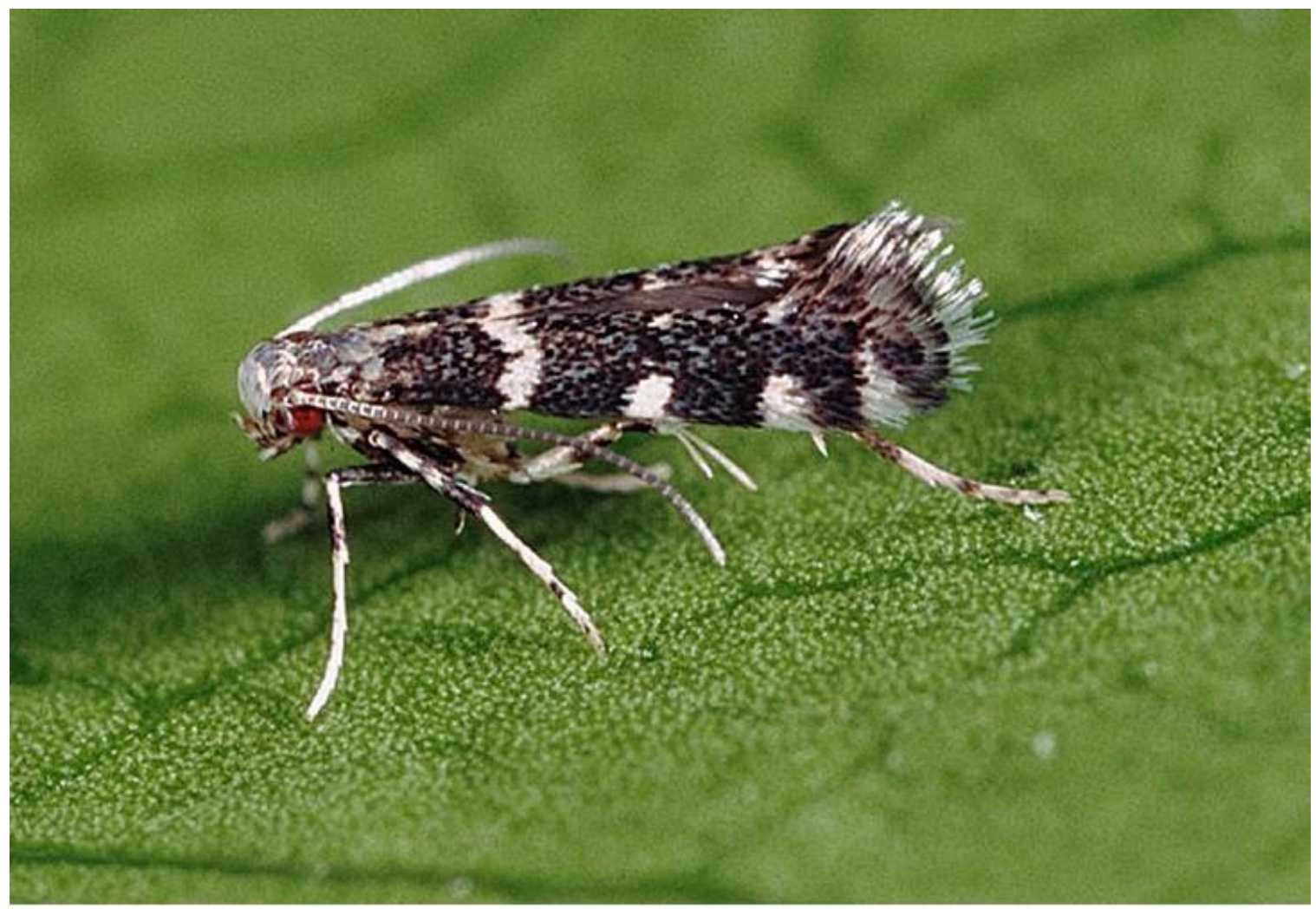

Figure 3. Marmara gulosa adult (photo courtesy of Dr. Beth Grafton-Cardwell)

\section{$\underline{\text { Distribution }}$}

The genus Marmara is endemic to the New World (Guillen et al. 2001).

Marmara gulosa and 21 other Marmara species have been described, seventeen of which are found in North America (Clemens 1860, 1863; Chambers 1875; Busck 1906, 1909; Braun 1909; Vinal 1917; Forbes 1923; DeGryse 1943; Fitzgerald 1973, 1975; Davis 1983; Guillen et al. 2001).

\section{$\underline{\text { Host Plants }}$}

Marmara gulosa has a host plant list of 69 species in 31 families (Godfrey et al. 2003; Grafton-Cardwell et al. 2008). Some common crop plant species attacked include: 
grapefruit (Citrus paradis Macfadyen), lemon (Citrus limon Burmann), tangerine (Citrus reticulata Blanco), lime (Citrus aurantifolia Tanaka), orange (Citrus sinensis Osbeck), nectarine (Prunus persica var. nucipersica L.), grape (Vitis vinifera L.), olive (Olea europaea L.), walnut (Juglans spp. L.), cotton (Gossypium hirsutum L.), oleander (Nerium spp. L.), willow (Salix spp. L.), avocado (Persea americana Mill), some squash (Family Cucurbitaceae Juss), and some peppers (Capsicum annum L.) (Atkins 1961; Atkins 1971; Guillén 1999; Guillén et al. 2001; Godfrey et al. 2003, Grafton-Cardwell et al. 2008). Many citrus varieties have been observed to be hosts for M. gulosa, but M. gulosa is especially active on pummelos, grapefruit, and certain varieties of navels (Reeves 1995; Guillén 1999; Guillén et al. 2001; Grafton-Cardwell et al. 2008). Navel varieties that appear preferred by M. gulosa include Fukumoto, Thompson Improved, Powell, Atwood, Barnfield, and Lane Late (Grafton-Cardwell et al. 2008).

The diverse and expanding host plant list of M. gulosa is not usual among insects because most phytophagous insects exhibit some degree of specialization on their host plants and only include novel host plants that are chemically and taxonomically similar to the original host plants (Jaenike 1990 and Vanbergen et al. 2003). The host list for $M$. gulosa has been expanding to taxonomically and chemically different host plants in the San Joaquin Valley since 1999 (Neff 2002). Host range expansion onto plants from many taxonomically and chemically different families is associated with insects that 1) have a larger body size 2) have silk assisted feeding or have exposed larval feeding 3) overwinter as eggs 4) usually feed on woody shrubs or trees 5) and usually occur in grasslands or upland habitats (Fraser et al. 1994 and Vanbergen et al. 2003). Marmara gulosa does not have a large body size, does not have silk assisted feeding or exposed 
larval feeding, is not known to overwinter as ova nor do they occur in grasslands.

However, M. gulosa does feed on woody shrubs and trees. Insects that incorporate novel host plants will also usually move onto host plants chemically similar to the original host (Jaenike 1990). This also is not the case with M. gulosa.

There are two factors that are recognized as important influences on polyphagous feeding. First is the production of chemical defenses by the plant, and second is the availability of the plant as a predictable food source (Cates et al. 1975; Feeny 1976; Rhoades et al. 1976; Cates et al. 1977; Cates 1980). Resources preferred by polyphagous herbivores that are predictable food sources, such as abundant woody perennials, mature leaves, and plants with bark, contain defenses that reduce digestibility (Cates 1980). Resources preferred by monophagous and oligophagous herbivores that are not always predictable food sources, such as rare annual plants, leaves that are rapidly flushing, and flowering plants, contain defenses that disrupt herbivore digestion (Cates 1980).

Oligophagous and monophagous herbivores are specialized on one or few plants and have resistance to the toxins that disrupt digestion, whereas polyphagous feeders do not have this adaptation (Feeny 1976; Rhoades et al. 1976; Cates et al. 1977; Scriber et al. 1979; Cates 1980). The mature plant tissue is harder to digest but lower in toxins than young tissue and flowers (Cates 1980); for this reason it is believed polyphagous feeders prefer mature tissue. Based on leaf tissue preferences of 35 Lepidoptera and Coleoptera, on 46 different plant species, nine of eleven polyphagous lepidopteran species preferred mature leaves on the herbaceous and woody perennials (Cates 1980). The polyphagous species that do prefer younger tissues all feed upon rare unpredictable annual and herbaceous perennial plant species (Cates 1980). Cates (1980) believes the rare plants 
escape herbivory in space and time rather than by chemical toxins. Based on oviposition observations $M$. gulosa seems to prefer host plants with rapidly expanding tissue, such as young growing leaves, suckers, or expanding fruit with a lot of moisture. The chemical composition of the new host plant does not seem to influence $M$. gulosa except when on citrus. Marmara gulosa larvae on citrus have exhibited mortality particularly on Fukumoto navels. The reason for the mortality in larvae ranging from second to fourth instars is unknown. Samples of deceased larvae were sent to Dr. Brian Federici at the University of California, Riverside, but no conclusive results were determined. Dr. Kris Godfrey from the CDFA collected deceased larvae from the San Joaquin Valley and sent them to pathologist Michael McGuire USDA, ARS, Shafter, CA. Michael McGuire also had no conclusive results as well. Mortality could be due to the lack of adaptation on citrus.

Studies of Microlepidoptera show a variety of host range expansions onto different host plants within any given moth family (Thompson et al. 1991). Thompson et al. (1991) and Powell (1980) found microlepidopteran families Gelechiidae, Gracillariidae, and Tortricidae to have some species expand onto over 70 new families of plants. Polyphagous feeding is not well documented because the herbivores are generally studied when they are at epidemic levels when their original host plants are under some environmental stress (Cates 1980). M. gulosa populations have increased since 1999 and the host range has expanded (Neff 2002). Cates' (1980) theory regarding environmental stresses on original host plants may be applicable to M. gulosa host plant species.

Host range expansion is more likely to occur when the insect performs as well on the new host plant as it does on the ancestral host plant, willow in the case of M. gulosa 
(Powell 1993 and Pilson 1999). New host plants may allow the insect to escape from predators, parasites, and pathogens providing even more incentive to switch onto novel host plants (Powell 1993 and Pilson 1999). Several steps must occur before a novel host plant can be included in the diet of a phytophagous insect. The five steps hypothesized to occur are: 1) a female must be able to find the host plant, 2) a female must accept the host plant as a suitable place to oviposit, 3) the larvae must accept the host plant as suitable, 4) the larvae must be able to find and recognize the host plant, and 5) the larvae must be able to grow and survive on the host plant (Rauscher 1982, 1983; Thomas et al. 1987; Thompson 1988; Bowers et al. 1992). According to the definition above, M. gulosa has incorporated novel host plants with verified rearings on avocado, citrus, cotton, grapes, oleander, peppers, tree tobacco, walnuts, and zucchini (Neff 2002 \& Finch 2003).

\section{$\underline{\text { Sex Ratios of Parasitic Hymenoptera }}$}

Parasitic Hymenoptera have a form of reproduction called haplodiploidy. Variable and unpredictable sex ratios are typically characteristic of parasitic Hymenoptera exhibiting haplodiploidy (Doutt 1964). Haplodiploidy indicates the number of chromosomes the organism has following embryogenesis (Wrensch et al. 1993). Organisms exhibiting haplodiploid reproduction reproduce parthenogenetically

and sexually (Daly et al. 1998). A fertilized egg is diploid and female. An unfertilized egg is haploid and male. The female has the ability to control offspring gender by allowing fertilization or not. Ratios of male to female in these populations vary depending upon environmental stimuli (Wrensch et al. 1993). Typically, there are more females than males in these populations, but many exceptions exist due to the diversity of organisms exhibiting haplodiploidy. 
Haplodiploid reproduction can be beneficial when a new population is being established. At first, an unfertilized foundress of a colony or population can only produce male offspring (Otto et al. 2001). There is a biological process that does not allow the female's egg to be fertilized even if gamete exchange has occurred (Wrensch et al. 1993). An example of this is with the solitary ichneumonid parasitoid Diadromus pulchellus (Kalmès et al. 2001). A mated female $D$. pulchellus only layed fertilized eggs half of the time she oviposited (Kalmès et al. 2001). This is beneficial because a female can produce all sons that she can mate with at a later time, if she survives long enough. As time progresses, the number of females increases and grows significantly larger than the number of males in a stable environment. The evolutionary reasoning for producing a population with a large number of females and a smaller proportion of males is to produce more progeny in the long run. The overproduction of males is biologically wasteful if the purpose of reproduction is to pass on genes from an individual. If a male dies without mating, the energy costs to produce him are lost and his genes will not be passed on. A larger proportion of females in a population allows for a greater number of offspring because population growth rates are determined by the number of females per female, also known as the intrinsic rate of natural increase $\left(R_{o}\right)$ (Varley et al. 1973).

Populations that occur in areas where conditions are atypical or resources are changing, the number of males increases to the proportion of females (Wrensch et al. 1993). This is thought to occur because males provide greater genetic diversity. In a study of haplodiploid mites, their sex ratios changed with different conditions (Wrensch et al. 1993). The original population of mites was maintained for five years at a temperature of $22^{\circ} \mathrm{C}$ and had more females than males. The mites were then subjected to 
a $32^{\circ} \mathrm{C}$ environment. Under the new temperature condition more males were produced. The reproductive strategy of the mites switched from maximizing $R_{0}$ to survival by attempting to increase genetic variation.

Looking at sex ratios of parasitic Hymenoptera may allow us to determine if a colony is new, changing, or established. If more females than males are present in the population, the population may be established and have existed long enough to reach this ratio. If there are more males than females present in the population the population may be new and just starting to establish or there has been a change in the environment that requires genotypic plasticity to cope with the stress. If there are an equal number of females to males then there are two possible explanations. One, the population could be in the middle of the process of establishing so the reproductive strategy has switched from male producing to female producing. Two, there has recently been an environmental change that requires genotypic plasticity and the reproductive strategy has switched from female producing to male producing. 


\section{Materials and Methods}

\section{Pre-release Surveys}

Pre-release surveys for M. gulosa activity on host plants and parasitoid activity on M. gulosa were conducted by Dr. Beth Grafton-Cardwell, UCCE and her staff, Dr. Kris Godfrey, CDFA, Pest Management Associates Inc., and Dr. David Headrick and his graduate students Dan Neff and Keith Speidel. Plants on which M. gulosa were feeding were noted. Any parasitoids found on M. gulosa were recorded and noted as being solitary or gregarious based on the presence of single or multiple emergence holes.

\section{Field Site Locations}

1. The Peterson Ranch- Located in Exeter, Tulare Co., CA on Road 180 just south of Ave 264 (Appendix A Map1). The east side of Road 180 just south of Ave 264 has a $0.081 \mathrm{~km}^{2}$ block of Fukumoto navel oranges and to the south a vacant field. The west side of Road 180 across from the Fukumotos has a block of oranges with a residence on the northern end, a farm shop with pink and white flowering oleander bushes surrounding the south eastern end, and grapes south of the oleander.

2. The Stutsman Ranch - Located in Exeter, Tulare Co., CA at Road 212, just north of Ave 256 (Appendix A Map2). This is a $0.02 \mathrm{~km}^{2}$ block of grapefruit inter planted with navel orange trees. This block is surrounded by several other citrus varieties.

3. $\mathrm{BFE}$ in Exeter, $\mathrm{CA}$ is on Avenue 288 or east Marinette 1.21 kilometers east of Highway 65 (Appendix A Map 3). BFE has oleander bushes in a row flanking the sides of a brick path. The pathway is surrounded by Washington navel oranges. 
4. Stewart's Residence in Exeter, CA is on the western most end of Ave 277 or Chestnut Street, 0.2 kilometers north on the gravel road (Appendix A Map 4). Stewart's Residence has two white flowering oleander bushes approximately 13 feet in diameter close to a residence that had been pruned within the last year. A residential garden including plants such as Mellow Gold grapefruit trees, nonwatered oleander, roses, and figs are in the immediate vicinity of the oleander bushes used for sampling. There are plum orchards east and west of the oleander site. Ten branches on ten different bushes were inspected each week.

5. The Kaweah River site is located in Woodlake, Tulare Co., CA (Appendix A Map 5) at the intersection of highway 245 and Cottage P.O. The citrus planting is comprised of navel trees to the south of the intersection, willow along the western side of highway 245 , cotton just north of the citrus, and a river north of the cotton.

6. The Quezada orchard is located at Ave 188, Rd. 212 Lindsay, Tulare Co., CA (Appendix A Map 6). This is a $0.02 \mathrm{~km}^{2}$ block that consists of navel orange trees with Oro Blanco grapefruit trees in row 1 at tree 5, row 1 tree 10, and row 10 tree 8. There is a residence to the north and a navel orange orchard to the south. Navel oranges also serve as borders to the west and east.

7. The Lewis Creek site is located in Lindsay, Tulare Co., CA at the south western intersection of Ave 220 and $\operatorname{Rd} 258$ on $\mathrm{Rd} 258$ along the creek.

8. The Muller walnut site is located in Visalia, Tulare Co., CA at the south east of the intersection of Caldwell Ave and Santa Fe Road (Appendix A Map 7). 


\section{Cirrospilus coachellae Releases}

A gregarious, non-hyperparasitic parasitoid, Cirrospilus coachella Gates (Fig. 4), was found providing population regulation of M. gulosa in the Coachella Valley (Guillén et al. 2001).

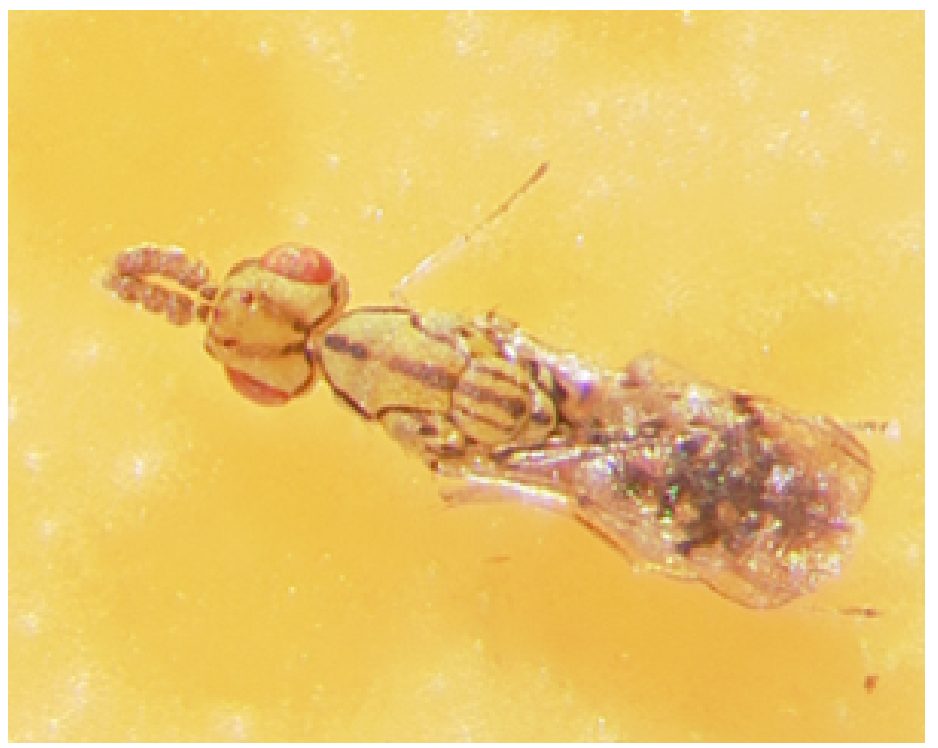

Figure 4. Cirrospilus coachellae Gates.

Cirrospilus coachellae was not observed in pre-release studies in the San Joaquin Valley, therefore it was chosen as the best candidate for introduction. Cirrospilus coachella releases were performed in the attempt to provide more biological control of M. gulosa in the San Joaquin Valley beginning 2001.

\section{Free releases: Summer of 2002}

The Peterson Ranch and the Stutsman Ranch were locations where free releases were conducted. Cirrospilus coachellae was released into Peterson's oranges on September 19, 2002. All specimens were field collected by Neil Smart in Riverside, Riverside Co., CA and put into a four dram glass vials. The vials were sent via overnight delivery in a cooler with ice packs from UC Riverside to California Polytechnic State 
University, San Luis Obispo. The day the package arrived the glass vials were immediately put into a refrigerator where they remained until the following day. The vials containing the parasitoids were then transported in a cooler with an ice pack to the release location. The glass vials were removed from the cooler, parasitoids were counted but not sexed, and the vials were taped to selected branches and opened (Fig. 5).

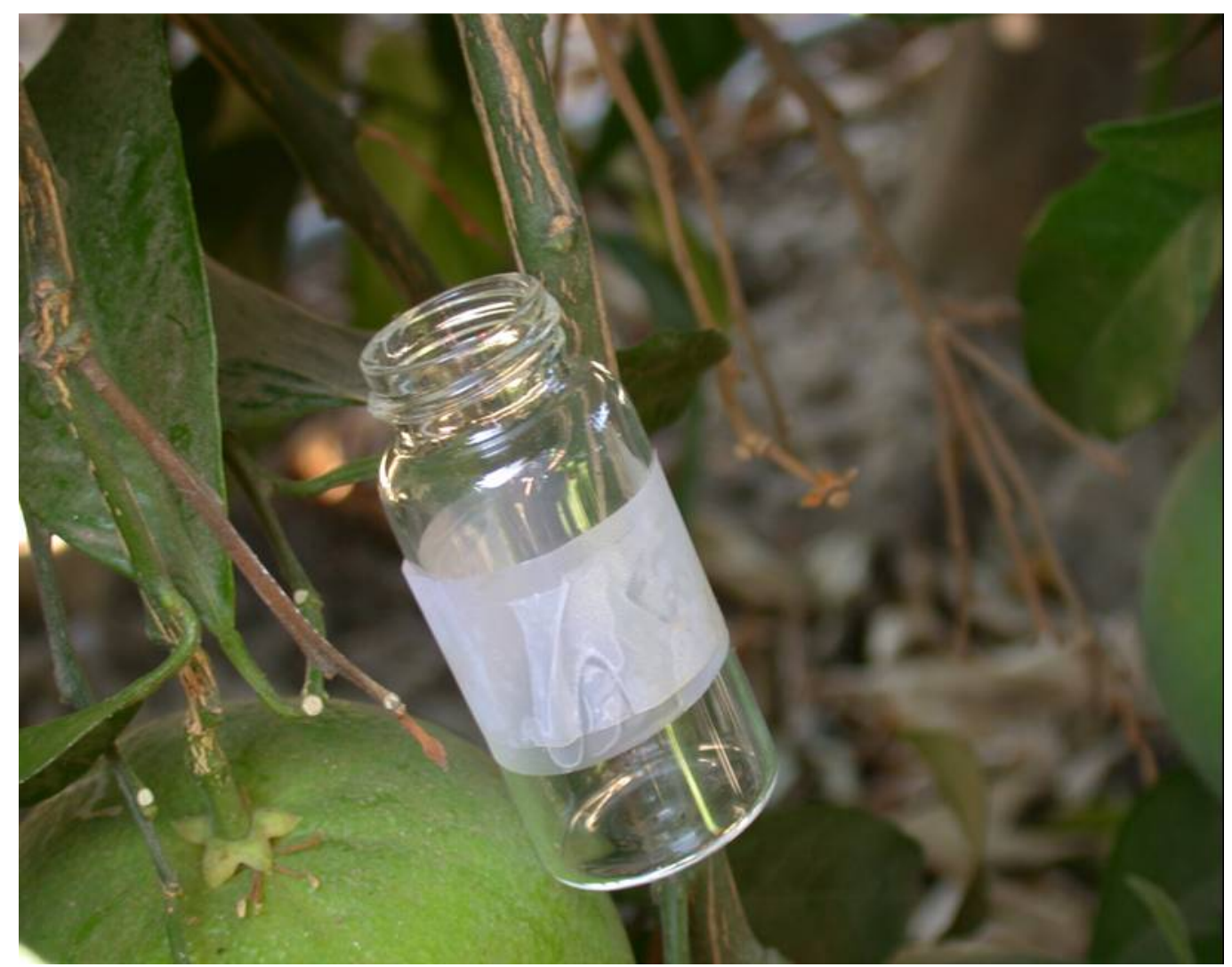

Figure 5. Glass vial taped to a branch for the release of Cirrospilus coachellae.

Rows were counted successively from one starting in the southern end of the block going to the northern end, and trees were counted successively from one starting in the west moving east. Twenty-three parasitoids were released in row 14 tree 9 . Twenty-two parasitoids were released in row 25 tree 9 . Nineteen parasitoids were released in row 20 tree number 20. All the releases were made in areas where there were high concentrations of live M. gulosa. The areas of high concentration were on the 
northeastern side of the trees from ground level up. A second release of 20 parasitoids in row 14 tree number 9 was made into Peterson's oranges on September 27, 2002 as described above.

Cirrospilus coachellae releases were made into Stutsman's grapefruits on September 19, 2002; all releases were conducted as above. Rows were counted successively from one beginning at the southern end of the block moving to the northern end, and trees were counted successively from one beginning at the west moving eastward. Twenty parasitoids were released in row number 15 tree number 8 , and 16 parasitoids were released in row number 20 tree number 18 . A second release of 14 parasitoids in row 15 tree number 8 was made into Stutsman's grapefruits on September $27,2002$.

\section{Oleander, Nerium spp, studies}

Weekly inspections of oleander, Nerium spp, were made at the Peterson Ranch in Exeter, Tulare Co., CA. The Peterson Ranch was monitored weekly from 8/6/03 through $12 / 9 / 03$. The end date of the oleander inspection was due to removal of the shrubs by the owner. Ten branches from ten different plants were inspected on a weekly basis from $8 / 6 / 03$ through $12 / 9 / 03$. Twenty-one bushes were included in the survey. Life status and life stage of $M$. gulosa, the number of old mines present, and parasitism, if present, were all recorded.

Weekly inspections of oleander, Nerium spp, were made at Badger Farming Exeter (BFE) and the Stewart Residence in Tulare Co. At BFE ten branches from ten different oleander bushes were inspected weekly from 3/31/04-7/21/04. A total of fifteen oleander bushes were included in this study. The bush number, life stage and life status 
of M. gulosa, occurrence of old mining on the branch, and parasitism, if present, were recorded weekly. Branches with parasitized $M$. gulosa were cut to fit into 0.1 liter plastic soufflé cups. Individual branches were put in the soufflé cups with a strip of paper towel and a clear plastic lid was placed on top. Cups were labeled with the location and the date collected. All cups were placed in a growth chamber with a photoperiod 14:10 (1:d) at $30^{\circ} \mathrm{C}$ until emergence. Each newly emerged parasitoid was then placed in 95 to $100 \%$ EtOH for storage.

At the Stewart Residence 25 branches on two different bushes were inspected each week. The branch number, life stage and life status of the M. gulosa, occurrence of old mining on the branch, and parasitism were recorded weekly from 5/5/04 through 7/21/04. Branches with parasitized M. gulosa were treated as described above.

September 8, 2005 BFE and the Stewart Residence were checked for evidence of parasitism. BFE oleander was inspected for one hour by two people. The oleander at the Stewart Residence was inspected by two people for ca. 20 minutes.

\section{$\underline{\text { Monitoring Citrus }}$}

Citrus was monitored at the Kaweah River site (Appendix A Map 5), the Stutsman Ranch (Appendix A Map 2), Bert Quezada's Ranch (Appendix A Map 6), and the Peterson Ranch (Appendix A Map 1). The Kaweah River site was monitored weekly from April through December from 2002 through 2004. The Stutsman Ranch was monitored weekly from April through December from 2002 through 2003 and once a month from April through December in 2004. The Bert Quezada Ranch was monitored weekly from April through December from 2002 through 2003 and once every two months in 2004. The Peterson Ranch was monitored weekly from May to December from 
2002 through 2003 and twice in 2004. When found at any of the above locations, parasitized M. gulosa larvae were collected. The fruit was brought to the laboratory and placed into Bugdorms ${ }^{\circledR}$. Bugdorms ${ }^{\circledR}$ are collapsible $300 \mathrm{~cm}$ cube plastic cages. The top and bottom of the Bugdorm ${ }^{\circledR}$ are composed of nearly transparent plastic, three sides are composed of $0.4 \times 0.6 \mathrm{~m}$ plastic mesh screen, and the fourth side provides access through a $0.2 \mathrm{~m}$ diameter opening with a nylon sleeve. Bugdorms ${ }^{\circledR}$ were placed into a growth chamber at $30^{\circ} \mathrm{C}$ with a photoperiod of $14: 10$ (1:d). Relative humidity was maintained at approximately 75\% using a $\mathrm{NaCl}$ and water solution (Winston and Bates 1960). Insects were checked daily for emergence.

Reared adults were put into 95 to $100 \%$ EtOH in individual two dram glass screw cap vials. After at least 24 hours in $100 \%$ EtOH insects were curated, see methods below.

$\underline{\text { Search for natural enemies on host plants other than citrus and oleander }}$ Inspection for evidence of parasitism of M. gulosa was conducted on the following peelminer host plants: Juglans sp. (walnuts), Gossypium sp. (cotton), Salix sp. (willow), or Nicotiana glauca (tree tobacco). Walnuts were examined for approximately 15 minutes by two to three people each week or bimonthly from March to June from 2002 through 2004. Cotton was monitored at the Kaweah River site. Cotton was examined for approximately 15 minutes on a weekly basis from time of emergence to plow down from 2002 through 2004. Willow was examined for approximately 30 minutes by two to three people, weekly, from February through November from 2002 through 2004 at the Kaweah River site. Willow was examined for approximately 30 minutes by two to three people twice a year from 2002 through 2004 at the Lewis Creek 
site. Tree tobacco was monitored at the Kaweah River site. Tree tobacco was examined for approximately 15 minutes by two to three people on a monthly basis from February through November from 2002 through 2004. Willow was checked at the Kaweah River site and the Lewis Creek site. Tree tobacco and cotton were checked at the Kaweah River site.

\section{$\underline{\text { Curation of Natural Enemies }}$}

Adult parasitoids were killed and stored in $100 \% \mathrm{EtOH}$ for at least 24 hours after they were recovered from individual containers in growth chambers. Fine woven copper mesh was cut into $2 \mathrm{~cm}$ diameter circles and molded to fit in a $4 \mathrm{~cm}$ diameter glass dish. The insects were placed individually onto the mesh circles in the glass plates that were then placed under a fume hood where several drops of hexamethyldisilazane ([(CH3)3Si]2NH), HMDS, were placed into the dish on top of the insect. The HMDS was allowed to evaporate off under the fume hood and the process was repeated until the insect was clean. Insects were mounted using a dissecting microscope with water-diluted white glue onto cardboard mounting cards. Insects were then identified using the Annotated Keys to the Nearctic Chalcidoidea (Hymenoptera) by G. Gibson, J. Huber, and J. Woolley.

$\underline{\text { Sex ratios, clutch sizes, and frequency of parasitism on oleander }}$

Branches with parasitized $M$. gulosa were cut to fit into individual $0.1 \mathrm{~L}$ plastic soufflé cups. Individual branches were put in the soufflé cups with a strip of paper towel and fitted with a clear, plastic lid. Cups were labeled with the location and collection date, and treated as above until emergence. Clutch sizes were recorded in each plastic soufflé cup. After the parasitoids were mounted on cards (see details in Curation of 
Natural Enemies) a dissecting microscope was used to determine the sex of each

parasitoid reared from oleander at BFE and the Stewart Residence. All information was entered into an Excel ${ }^{\mathrm{TM}}$ spreadsheet and put in chronological order with the oldest dates listed first. 


\section{Results}

\section{Pre-release survey}

Parasitic Hymenoptera were recorded attacking M. gulosa in the San Joaquin Valley on citrus and other host plants, but currently do not provide sufficient control in commercial citrus plantings (Godfrey and Mayhew, Grafton-Cardwell, Headrick, unpublished data). Five different genera of eulophids have been identified attacking $M$. gulosa in the San Joaquin Valley: Pnigalio, Closterocerus, Baryscapus, Nechrysocharoides, and Hemiptarsenus.

\section{Cirrospilus coachellae releases}

Successful establishment has not yet been observed in the San Joaquin Valley following annual releases from 2001 to 2004 . Recoveries have been made in the same season, but there have been no recoveries of adults following the previous season's releases. Releases may become more effective when large quantities of $C$. coachellae can be released reliably throughout the year.

\section{Oleander, Nerium spp, Monitoring}

Seventy-one parasitoids were reared from peelminer infested oleander branches in 2004. All of the parasitoids collected from oleander at the Stewart Residence and BFE were determined to be Hadrotrichodes waukheon La Salle (Fig. 6). 


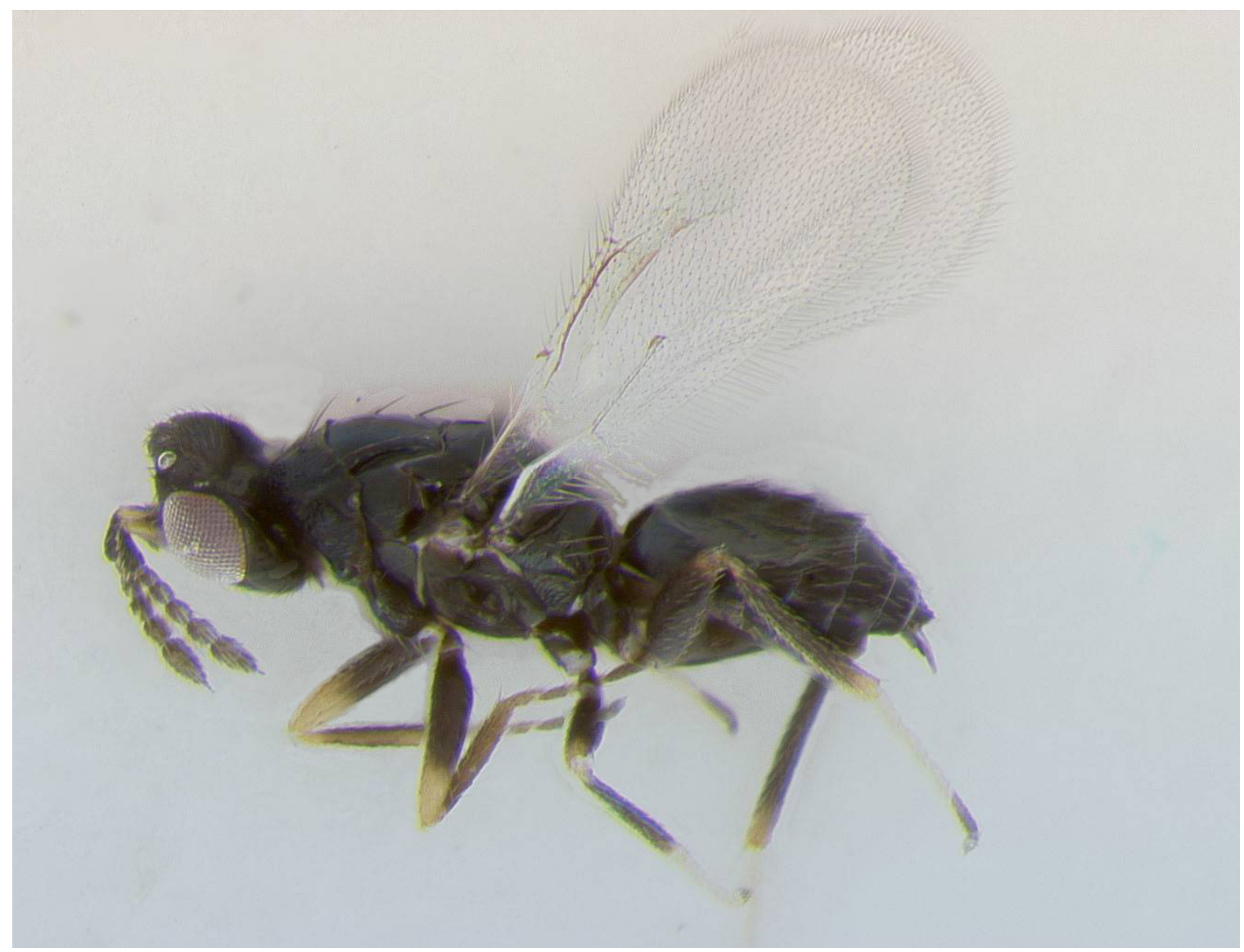

Figure 6. Hadrotrichodes waukheon male

All identifications were verified by Dr. John Heraty and Mr. Roger Burks, UC Riverside.

No H. waukheon were observed at BFE or the Stewart Residence in 2005 and

only one H. waukheon was found at the Stewart Residence in 2006. Active and old mines of M. gulosa were present, but only one parasitoid was found at the Stewart Residence. 


\section{$\underline{\text { Parasitism on Oleander }}$}

Of the 538 live M. gulosa larvae examined on Nerium sp. (oleander) from 3/31/2004 through 7/21/2004, 36 (6.65\%) were parasitized at BFE (Fig. 7 and Fig. 8).

Percent parasitism was calculated by collection date at BFE. Parasitism ranged from $5.1 \%$ to $18.2 \%$ (Fig. 9). Of the 242 M. gulosa larvae examined at Jim Stewart's residence from 5/5/2004 through 7/21/2004, 27 (11.16\%) were parasitized (Fig. 10 and Fig. 11). Percent parasitism was calculated by collection date at the Stewart's residence. Parasitism ranged from $9.1 \%$ to $45 \%$ (Fig. 12). 


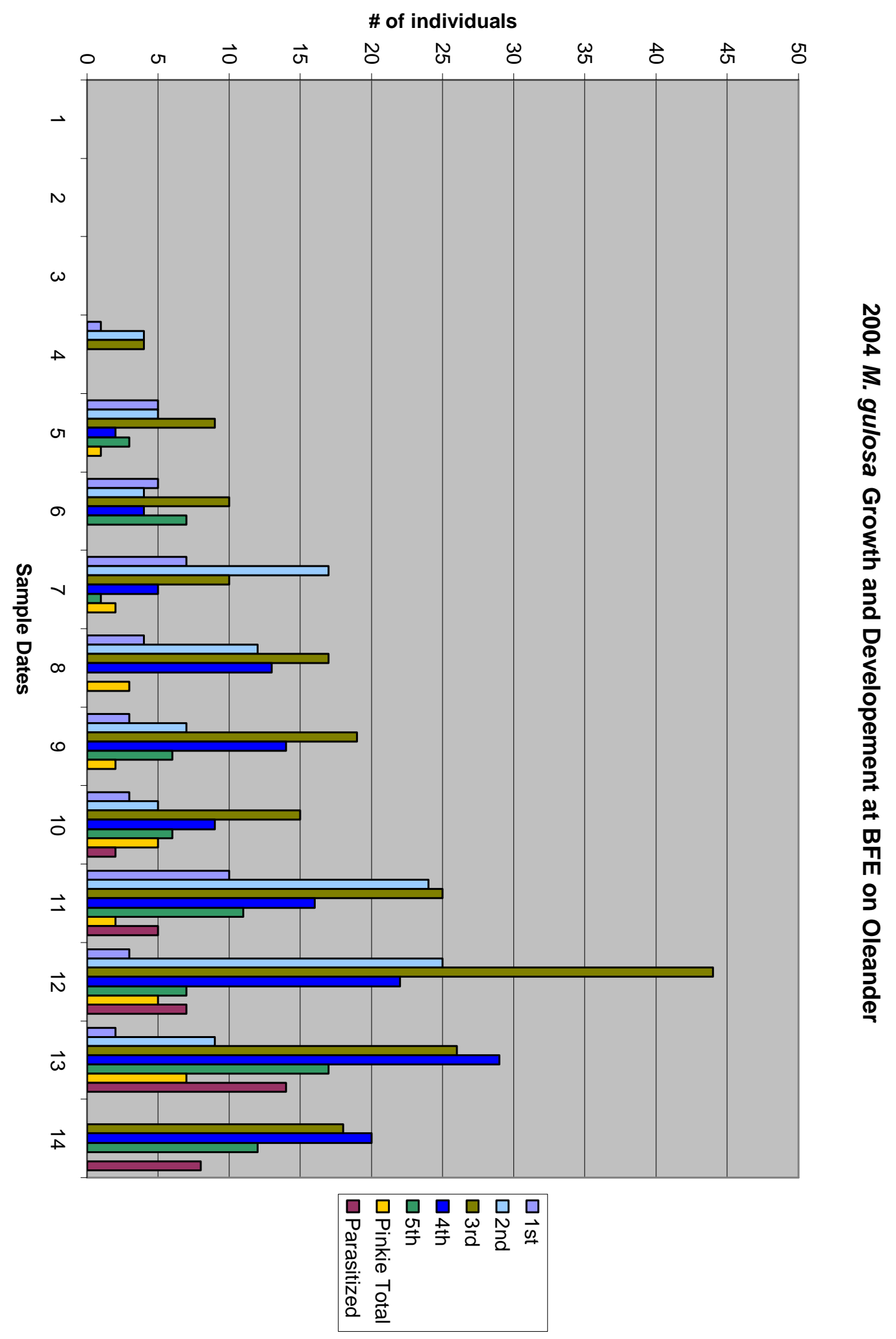

Figure 7. Growth and development of M. gulosa on BFE oleander in 2004. 
M. gulosa Stages Parasitized at BFE 2004

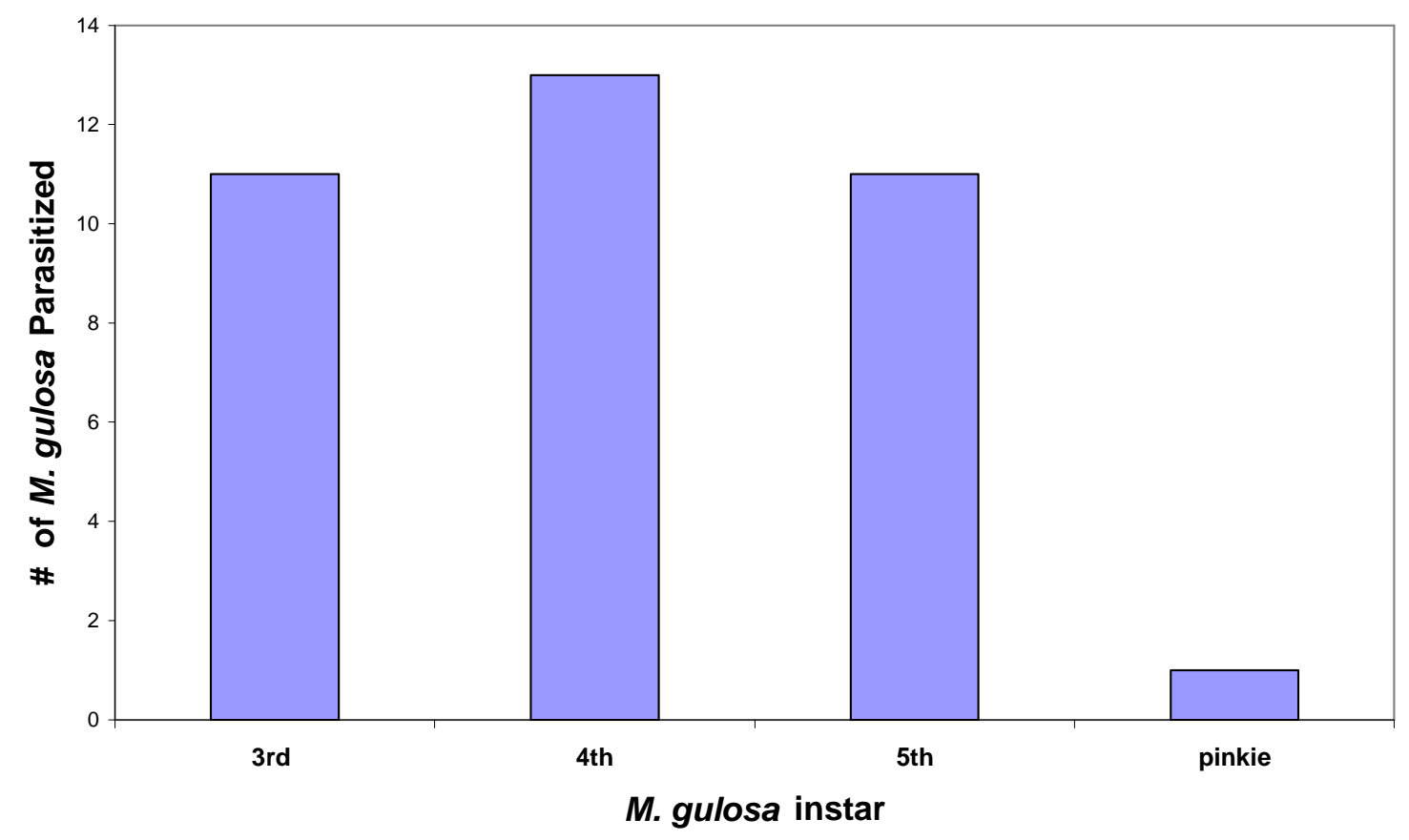

Figure 8. Stages of M. gulosa parasitized on BFE oleander in 2004. 
\% of M. gulosa Parasitzed by H. waukheon at BFE in 2004 by collection date

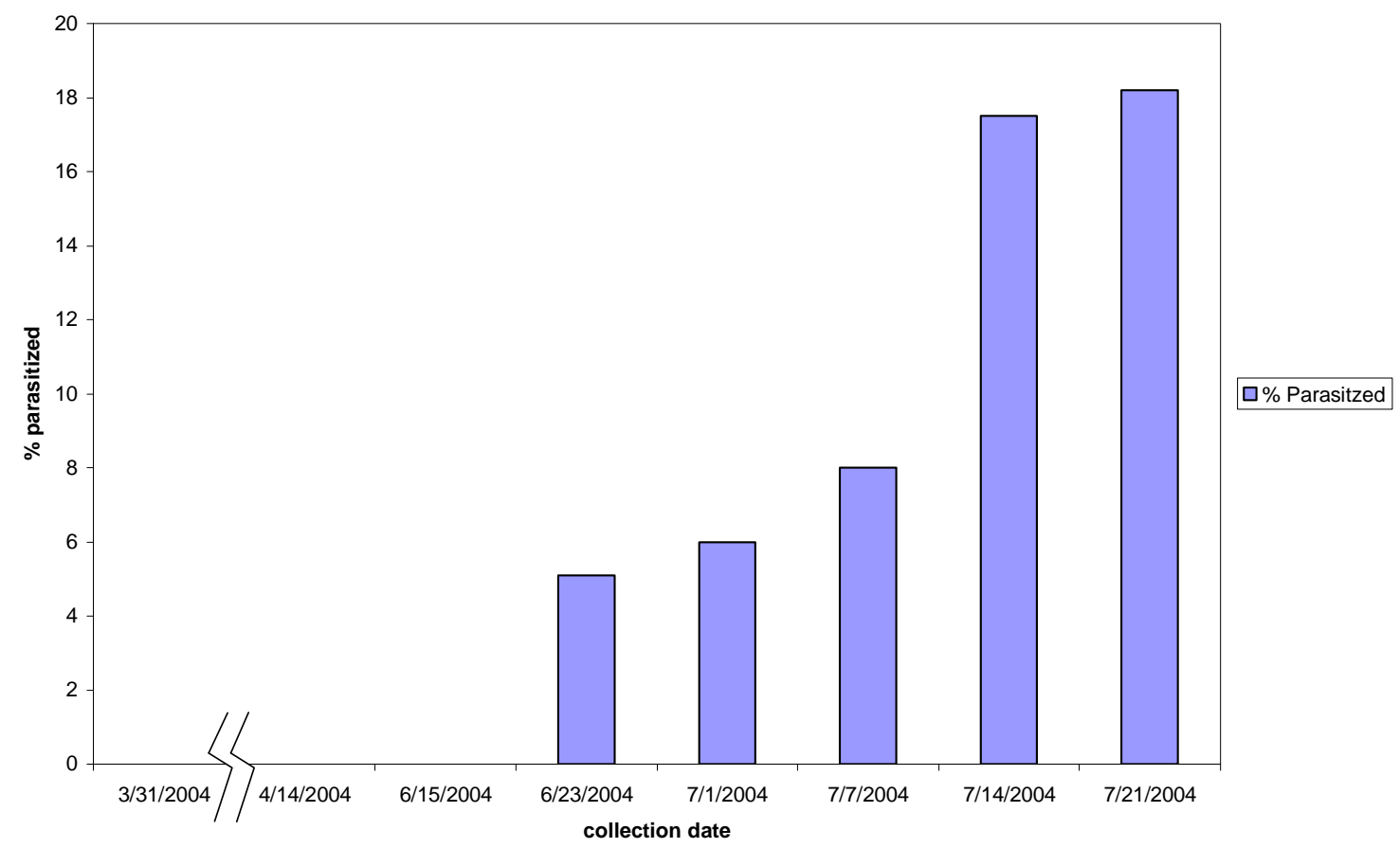

Figure 9. Percent parasitism of $M$. gulosa by $\mathrm{H}$. waukheon by collection date at BFE in 2004. 


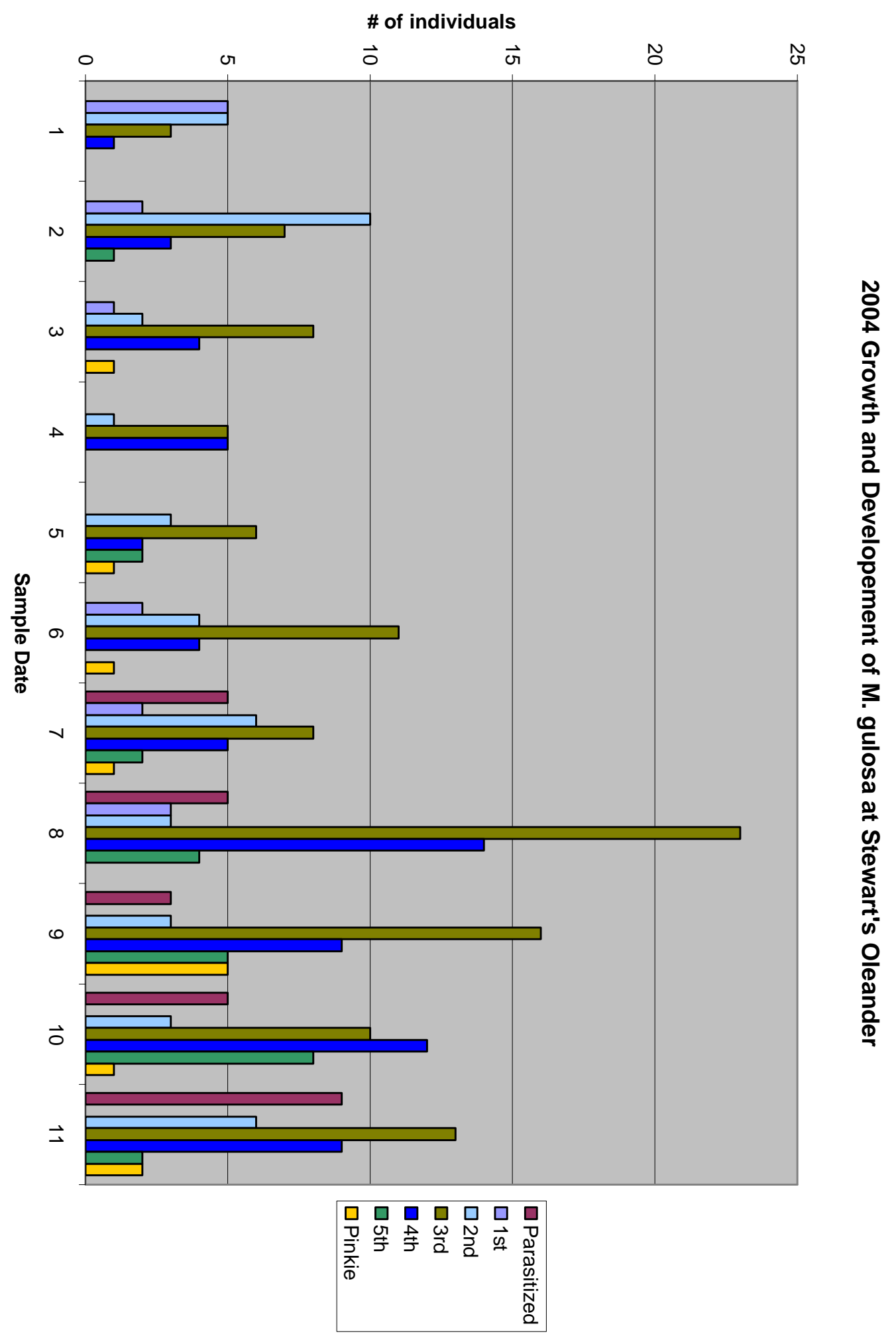

Figure 10. Growth and development of M. gulosa on Stewart's oleander in 2004. 
M. gulosa Stages Parasitized at Stewart's Oleander 2004

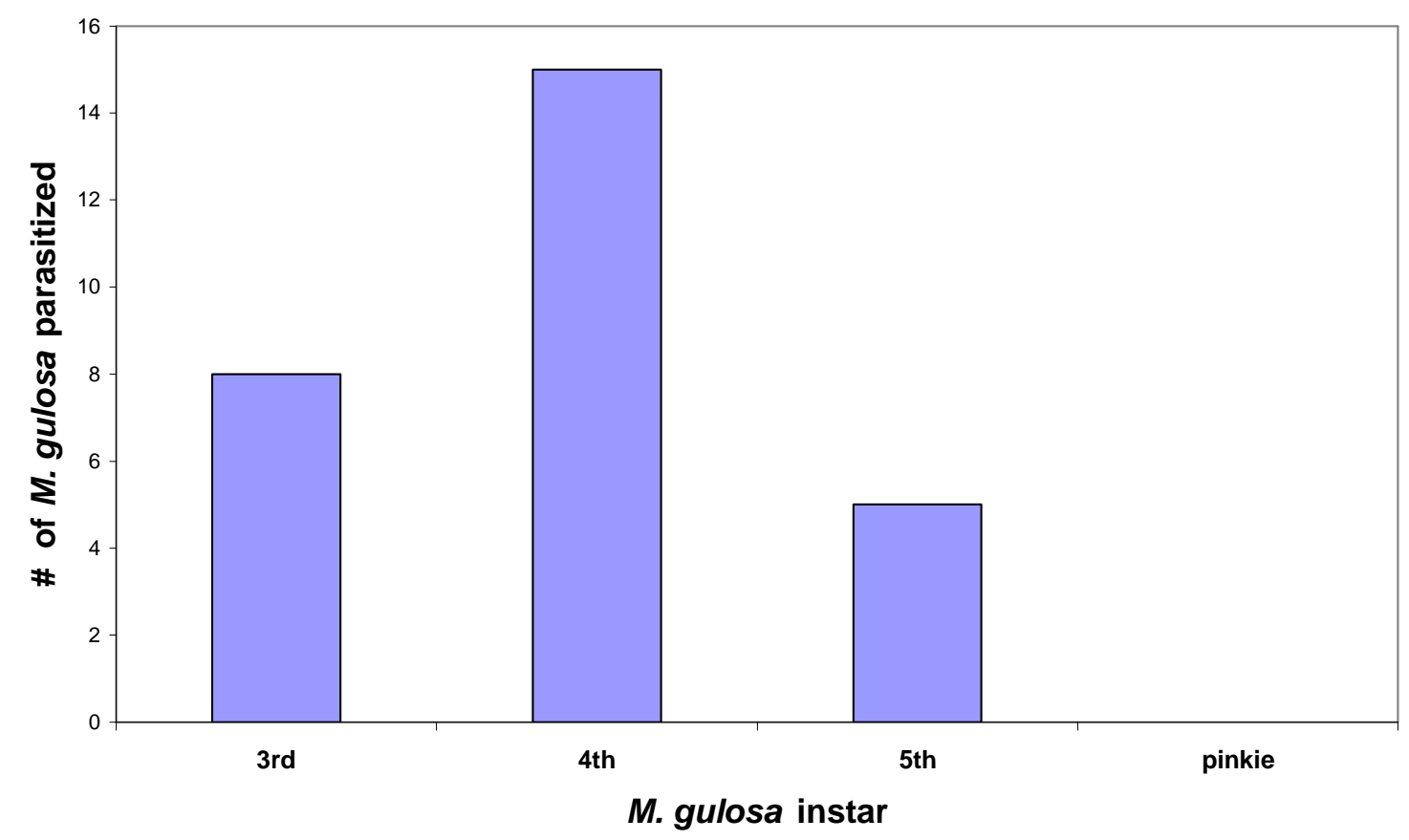

Figure 11. Stages of M. gulosa parasitized on Stewart's oleander in 2004. 
\% Parasitism of M. gulosa by H. waukheon at Stewart's Oleander in 2004

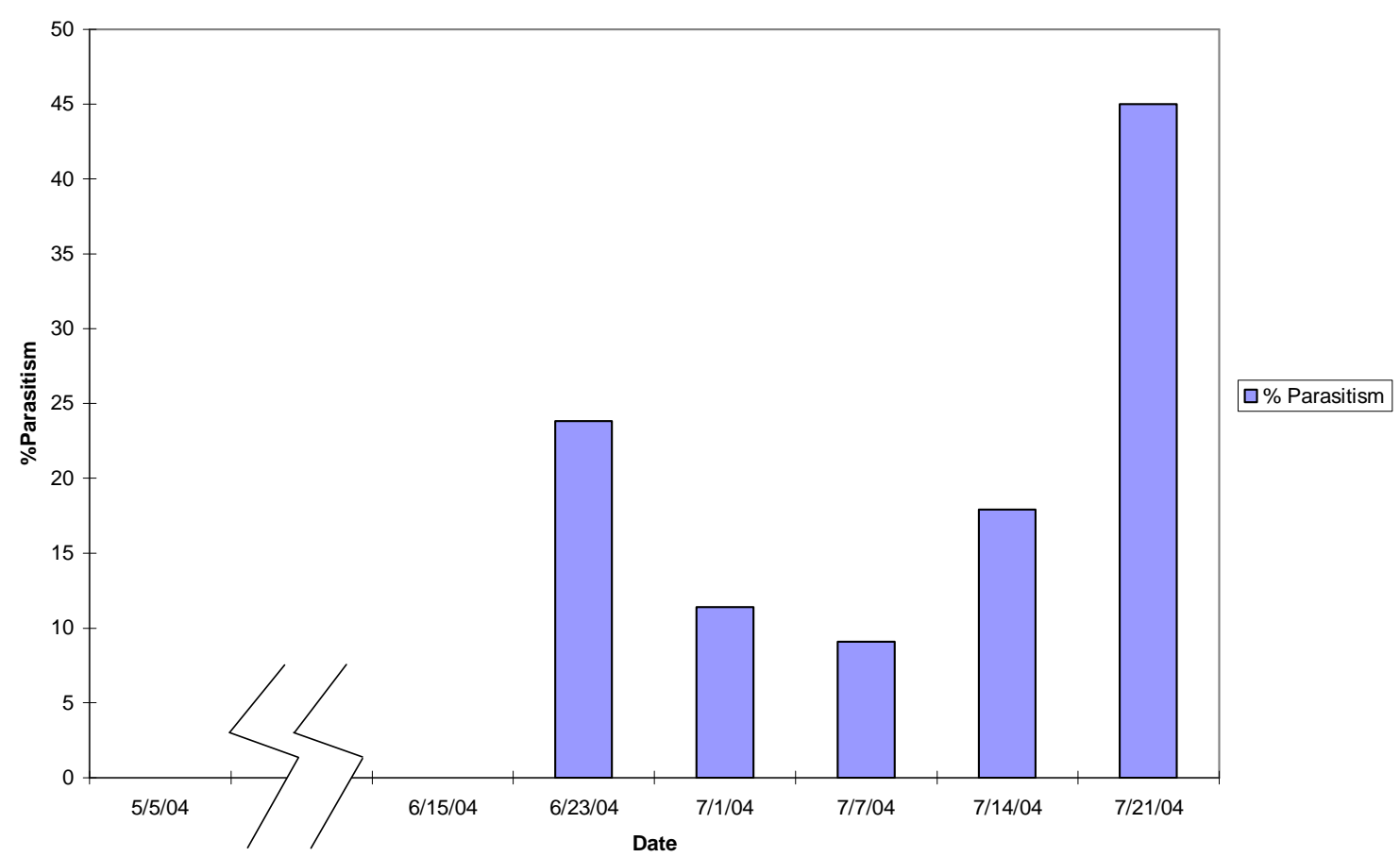

Fig. 12. Percent parasitism of $M$. gulosa by $\mathrm{H}$. waukheon by collection date at Stewart's oleander in 2004. 


\section{$\underline{\text { Monitoring Citrus }}$}

Collection of parasitized M. gulosa larvae from 2002 to 2004 from monitoring at

the Kaweah River site, the Stutsman Ranch, the Peterson Ranch, the Quezada Ranch, and specimens collected by Yuling Ouyang in Parlier yielded a total of 15 parasitoids reared from citrus. Eight parasitoids were reared from navel oranges and seven were reared from grapefruit. Of the eight reared from navels, seven were reared from the Quezada Ranch while one was reared from the Kaweah River site. Of the seven reared from grapefruit, four were reared from the Stutsman ranch and three were reared from Parlier. Those reared from navels at the Quezada Ranch were identified as follows: four Closterocerus diastatae Westwood, one Closterocerus utahensis Crawford and two Hemiptarsenus sp. Westwood. The parasite from the Kaweah River site reared from a navel was identified as Pnigalio coloni Shrank. Those reared from grapefruit at the Stutsman Ranch were identified to be from the family Encyrtidae and in the genus Comperiella Howard. Those reared from grapefruit at Parlier were identified to be Closterocerus sp.

$\underline{\text { Search for Natural Enemies on Host Plants Other Than Citrus and Oleander }}$ One parasitoid larva was found on a cotton stem at the Kaweah River site. The parasitoid was not visible under the epidermis. Only because $M$. gulosa larvae were being dissected from cotton for genetic studies was the parasitoid discovered. The parasitoid was unfortunately destroyed upon dissection and could not be identified. No other host plants inspected, except cotton, citrus and oleander, had evidence of M. gulosa parasitism. 


\section{$\underline{\text { Curation }}$}

Dead, dried parasitoid specimens did not regain their external structural shape by treating them with HMDS. Specimens remained collapsed and dirty. A different method was obtained from Dr. John Heraty, UC Riverside, see Improved Methods for Rearing and Curation below.

\section{$\underline{\text { Sex Ratios, Clutch Sizes, and Frequency of Parasitism on Oleander }}$}

The following tables associate the parasitoids found in the surveys conducted in 2004 at Badger Farming Exeter (BFE) and the Stewart Residence to the parasitoids reared from oleander plants at these locations. This analysis was conducted to determine if there were any observable patterns in sex ratios, clutch sizes, or preferences in host locations. Sex ratios may provide a measure of the establishment process for these natural enemies as demonstrated by Wrensch et al. (1993) and Otto et al. (2001).

At BFE no sex ratio pattern (Fig. 13 and Fig. 14), clutch size pattern, or apparent host location preferences were identified (Table 1). The ratio of females to males, respectively, was 29:25 as shown in Tables 1 and 2. Parasitoids were found on the new growth of the oleander where there was a higher concentration of $M$. gulosa larvae. The oleander bushes had more parasitism on the south to southwest sides between $0.3 \mathrm{~m}$ from the ground to $1.2 \mathrm{~m}$ from the ground. The number of $M$. gulosa larvae parasitized on each bush was counted at BFE. All the bushes surveyed with the exception of bush 2 had parasitism. Between 0 and 5 larvae were parasitized on each bush and between 7 and 60 M. gulosa larvae were found on each bush throughout the survey (Table 2).

In the data from the Stewart Residence a pattern in the ratio of males to females was apparent (Fig. 13, Fig. 14, and Table 3). 
Male and Female Hadrotrichodes waukheon on BFE Oleander 2004 by Emergence Date

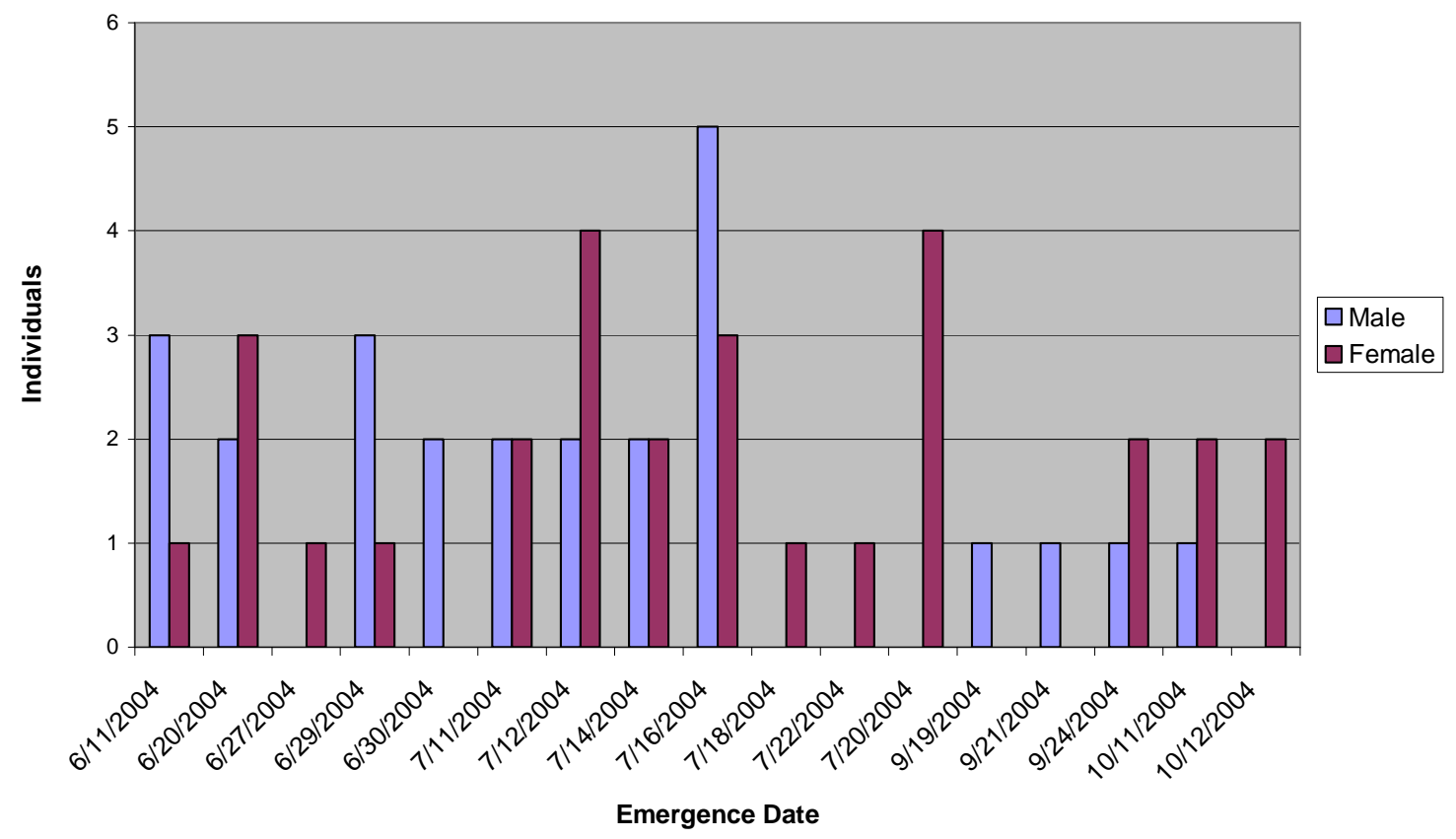

Figure 13. Quantities of male and female Hadrotrichodes waukheon reared from oleander by emergence date at BFE in 2004. 
Male and Female Hadrotrichodes waukheon on BFE Oleander 2004 by Collection Date

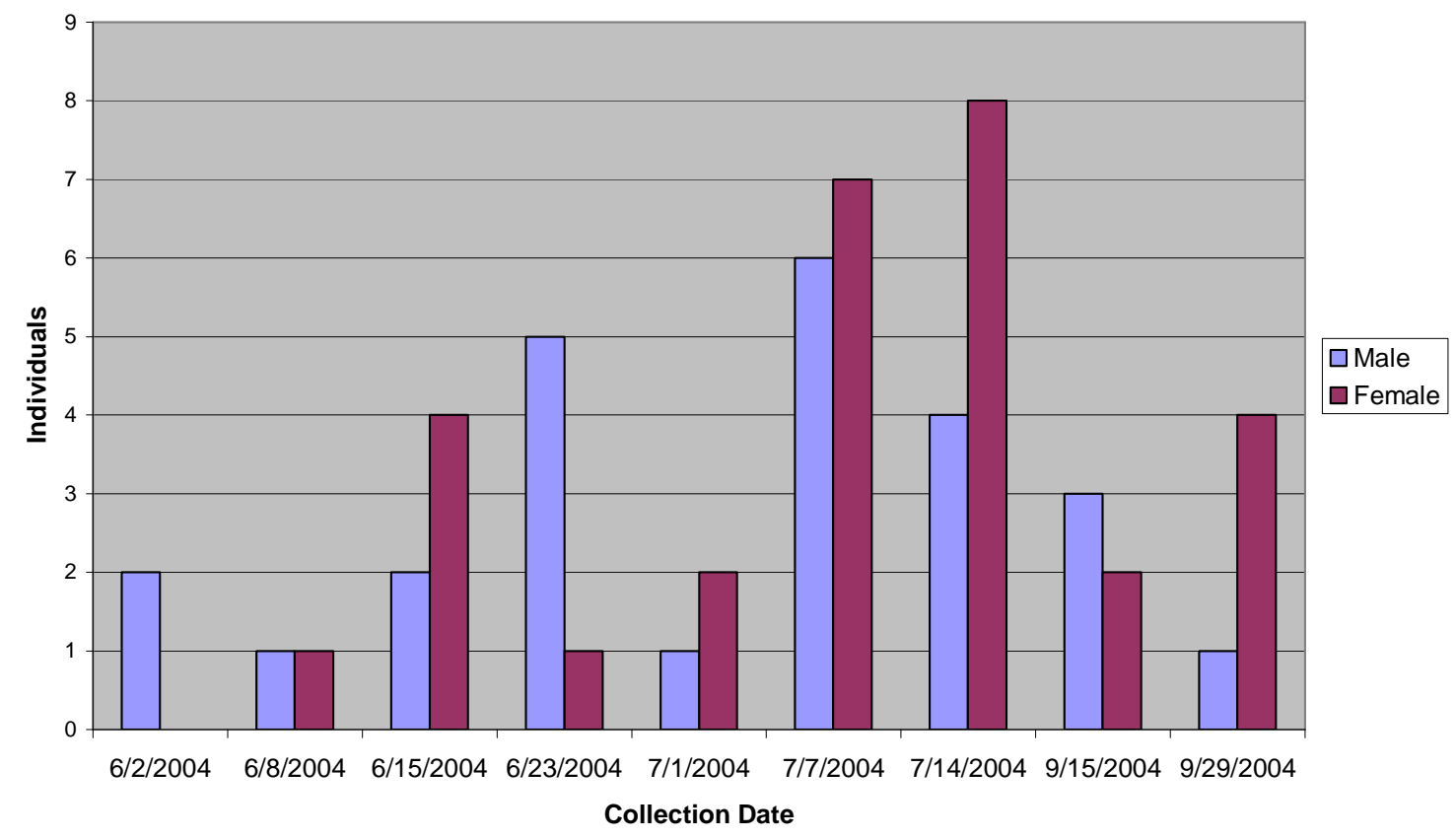

Figure 14. Quantities of male and female Hadrotrichodes waukheon reared from oleander by collection date at BFE in 2004. 


\begin{tabular}{|c|c|c|c|c|c|c|c|}
\hline \multicolumn{4}{|c|}{ Parasitoid collection data BFE 2004} & \multicolumn{4}{|c|}{ Growth and development data BFE 2004} \\
\hline Date Collected & Date Emerged & Sex & Clutch & Date & Bush \# & $\begin{array}{c}\text { Instar } \\
\text { Parisitized }\end{array}$ & $\begin{array}{l}\text { \# of Larvae } \\
\text { per Branch }\end{array}$ \\
\hline $6 / 2 / 2004$ & $6 / 11 / 2004$ & $\mathrm{M}$ & & & & & \\
\hline $6 / 2 / 2004$ & $6 / 11 / 2004$ & $\mathrm{M}$ & & & & & \\
\hline $6 / 8 / 2004$ & $6 / 11 / 2004$ & $\mathrm{M}$ & A & & & & \\
\hline $6 / 8 / 2004$ & $6 / 11 / 2004$ & $\mathrm{~F}$ & A & & & & \\
\hline $6 / 15 / 2004$ & $6 / 20 / 2004$ & $\mathrm{~F}$ & & & & & \\
\hline $6 / 15 / 2004$ & $6 / 20 / 2004$ & $\mathrm{~F}$ & B & & & & \\
\hline $6 / 15 / 2004$ & $6 / 20 / 2004$ & $\mathrm{M}$ & $\mathrm{B}$ & & & & \\
\hline $6 / 15 / 2004$ & $6 / 27 / 2004$ & $\mathrm{~F}$ & & & & & \\
\hline $6 / 15 / 2004$ & $6 / 20 / 2004$ & $\mathrm{M}$ & $\mathrm{C}$ & & & & \\
\hline $6 / 15 / 2004$ & $6 / 20 / 2004$ & $\mathrm{~F}$ & $\mathrm{C}$ & & & & \\
\hline $6 / 23 / 2004$ & $6 / 29 / 2004$ & $\mathrm{~F}$ & $\mathrm{D}$ & $6 / 23 / 2004$ & 3 & 3rd & 1 \\
\hline $6 / 23 / 2004$ & $6 / 29 / 2004$ & $\mathrm{M}$ & $\mathrm{D}$ & & & & \\
\hline $6 / 23 / 2004$ & $6 / 29 / 2004$ & $M$ & D & & & & \\
\hline $6 / 23 / 2004$ & $6 / 29 / 2004$ & $M$ & & $6 / 23 / 2004$ & 11 & $3 r d$ & 1 \\
\hline $6 / 23 / 2004$ & $6 / 30 / 2004$ & $\mathrm{M}$ & E & & & & \\
\hline $6 / 23 / 2004$ & $6 / 30 / 2004$ & $\mathrm{M}$ & $E$ & & & & \\
\hline $7 / 1 / 2004$ & $7 / 12 / 2004$ & $M$ & $\mathrm{~F}$ & $7 / 1 / 2004$ & 4 & pinkie & 1 \\
\hline 7/1/2004 & $7 / 12 / 2004$ & $\mathrm{~F}$ & $\mathrm{~F}$ & & & & \\
\hline $7 / 1 / 2004$ & $7 / 12 / 2004$ & $\mathrm{~F}$ & & $7 / 1 / 2004$ & 5 & 4th & 1 \\
\hline & & & & $7 / 1 / 2004$ & 8 & 4th & 1 \\
\hline & & & & $7 / 1 / 2004$ & 10 & 4th & 1 \\
\hline & & & & $7 / 1 / 2004$ & 14 & 5th & 1 \\
\hline $7 / 7 / 2004$ & $7 / 11 / 2004$ & $M$ & G & 7/7/2004 & 3 & 4th & 1 \\
\hline $7 / 7 / 2004$ & $7 / 11 / 2004$ & $\mathrm{~F}$ & $\mathrm{G}$ & & & & \\
\hline 7/7/2004 & $7 / 11 / 2004$ & $\mathrm{~F}$ & $\mathrm{G}$ & & & & \\
\hline $7 / 7 / 2004$ & $7 / 11 / 2004$ & $M$ & $G$ & & & & \\
\hline 7/7/2004 & $7 / 12 / 2004$ & $\mathrm{~F}$ & $\mathrm{H}$ & $7 / 7 / 2004$ & 6 & 5th & 1 \\
\hline 7/7/2004 & $7 / 12 / 2004$ & $\mathrm{~F}$ & $\mathrm{H}$ & & & & \\
\hline 7/7/2004 & $7 / 12 / 2004$ & $\mathrm{M}$ & $\mathrm{H}$ & & & & \\
\hline 7/7/2004 & $7 / 14 / 2004$ & $\mathrm{M}$ & 1 & $7 / 7 / 2004$ & 8 & $3 r d$ & 1 \\
\hline 7/7/2004 & $7 / 14 / 2004$ & $\mathrm{~F}$ & 1 & & & & \\
\hline $7 / 7 / 2004$ & $7 / 14 / 2004$ & $\mathrm{~F}$ & 1 & & & & \\
\hline 7/7/2004 & $7 / 14 / 2004$ & $\mathrm{M}$ & 1 & & & & \\
\hline 7/7/2004 & $7 / 16 / 2004$ & $\mathrm{M}$ & $\mathrm{J}$ & $7 / 7 / 2004$ & 9 & 4th & 1 \\
\hline 7/7/2004 & $7 / 16 / 2004$ & $\mathrm{~F}$ & $\mathrm{~J}$ & & & & \\
\hline 7/7/2004 & $7 / 16 / 2004$ & $\mathrm{~F}$ & $\mathrm{~J}$ & & & & \\
\hline & & & & 7/7/2004 & 15 & $3 r d$ & 3 \\
\hline $7 / 14 / 2004$ & $7 / 16 / 2004$ & $\mathrm{M}$ & $\mathrm{K}$ & $7 / 14 / 2004$ & 3 & $3 \mathrm{rd}$ & 1 \\
\hline $7 / 14 / 2004$ & 7/16/2004 & $\mathrm{F}$ & K & & & & \\
\hline $7 / 14 / 2004$ & $7 / 16 / 2004$ & $\mathrm{~F}$ & $\mathrm{~K}$ & & & & \\
\hline $7 / 14 / 2004$ & 7/18/2004 & $\mathrm{F}$ & & $7 / 14 / 2004$ & 7 & $3 \mathrm{rd}$ & 1 \\
\hline $7 / 14 / 2004$ & 7/20/2004 & $\mathrm{F}$ & & $7 / 14 / 2004$ & 7 & 4th & 1 \\
\hline $7 / 14 / 2004$ & 7/22/2004 & $\mathrm{F}$ & & $7 / 14 / 2004$ & 8 & 4th & 1 \\
\hline $7 / 14 / 2004$ & $7 / 16 / 2004$ & $\mathrm{M}$ & $L$ & $7 / 14 / 2004$ & 8 & 5th & 1 \\
\hline $7 / 14 / 2004$ & $7 / 16 / 2004$ & $\mathrm{M}$ & $\mathrm{L}$ & & & & \\
\hline $7 / 14 / 2004$ & $7 / 16 / 2004$ & $M$ & $L$ & & & & \\
\hline
\end{tabular}




\begin{tabular}{|c|c|c|c|c|c|c|c|}
\hline \multicolumn{4}{|c|}{ Parasitoid collection data at BFE 2004} & \multicolumn{4}{|c|}{ Growth and development data BFE 2004} \\
\hline Date Collected & Date Emerged & Sex & Clutch & Date & Bush \# & $\begin{array}{c}\text { Instar } \\
\text { Parisitized }\end{array}$ & $\begin{array}{l}\text { \# of Larvae } \\
\text { per Branch }\end{array}$ \\
\hline $7 / 14 / 2004$ & 7/20/2004 & $\mathrm{F}$ & M & 7/14/2004 & 9 & 5th & 1 \\
\hline $7 / 14 / 2004$ & $7 / 20 / 2004$ & $\mathrm{~F}$ & M & & & & \\
\hline $7 / 14 / 2004$ & $7 / 20 / 2004$ & $\mathrm{~F}$ & $\mathrm{M}$ & & & & \\
\hline & & & & $7 / 14 / 2004$ & 10 & 4th & 1 \\
\hline & & & & $7 / 14 / 2004$ & 12 & 4th & 1 \\
\hline & & & & $7 / 14 / 2004$ & 13 & 4th & 1 \\
\hline & & & & $7 / 14 / 2004$ & 13 & $3 r d$ & 1 \\
\hline & & & & $7 / 14 / 2004$ & 14 & 5th & 1 \\
\hline & & & & $7 / 14 / 2004$ & 14 & 5 th & 2 \\
\hline & & & & $7 / 14 / 2004$ & 14 & 4th & 1 \\
\hline & & & & $7 / 21 / 2004^{*}$ & 1 & 4th & 1 \\
\hline & & & & $7 / 21 / 2004^{*}$ & 3 & 5 th & 1 \\
\hline & & & & $7 / 21 / 2004^{*}$ & 5 & 3rd & 1 \\
\hline & & & & $7 / 21 / 2004^{*}$ & 15 & 5 th & 1 \\
\hline $9 / 15 / 2004$ & 9/19/2004 & $\mathrm{M}$ & & & & & \\
\hline $9 / 15 / 2004$ & $9 / 21 / 2004$ & $M$ & & & & & \\
\hline $9 / 15 / 2004$ & 9/24/2004 & $\mathrm{F}$ & $\mathrm{N}$ & & & & \\
\hline $9 / 15 / 2004$ & 9/24/2004 & $\mathrm{F}$ & $\mathrm{N}$ & & & & \\
\hline $9 / 15 / 2004$ & 9/24/2004 & $\mathrm{M}$ & $\mathrm{N}$ & & & & \\
\hline $9 / 29 / 2004$ & $10 / 11 / 2004$ & $\mathrm{M}$ & $\mathrm{O}$ & & & & \\
\hline $9 / 29 / 2004$ & $10 / 11 / 2004$ & $F$ & 0 & & & & \\
\hline $9 / 29 / 2004$ & $10 / 12 / 2004$ & $\mathrm{~F}$ & $\mathrm{P}$ & & & & \\
\hline $9 / 29 / 2004$ & $10 / 12 / 2004$ & $\mathrm{~F}$ & $\mathrm{P}$ & & & & \\
\hline 9/29/2004 & $10 / 11 / 2004$ & $F$ & & & & & \\
\hline
\end{tabular}

* half the number of samples taken from each bush

Table 1. Parasitoid collection data compared to rearing data: Parasitoid collection data includes collection date, emergence date, sex of the parasitoid found and clutches from BFE associated with parasitoid information from the growth and development survey conducted at BFE in 2004 including collection date, bush number sampled, the larval stage parasitized and the number of larvae on each branch. 


\begin{tabular}{|c|c|c|}
\hline Bush \# & \# Parasitized & \# of M. gulosa larvae on each bush \\
\hline 1 & 1 & 33 \\
\hline 2 & 0 & 25 \\
\hline 3 & 4 & 32 \\
\hline 4 & 1 & 60 \\
\hline 5 & 2 & 42 \\
\hline 6 & 1 & 33 \\
\hline 7 & 2 & 44 \\
\hline 8 & 4 & 47 \\
\hline 9 & 2 & 49 \\
\hline 10 & 2 & 47 \\
\hline 11 & 1 & 38 \\
\hline 12 & 1 & 35 \\
\hline 13 & 2 & 33 \\
\hline 14 & 5 & 34 \\
\hline 15 & 4 & 7 \\
\hline
\end{tabular}

Table 2. Total number of parasitoids found and total number of $M$. gulosa larvae found on each bush on all the combined sample dates during the growth and development survey at BFE in 2004. 
Male and Female Hadrotrichodes waukheon on Stewart's Oleander 2004 by Emergence Date

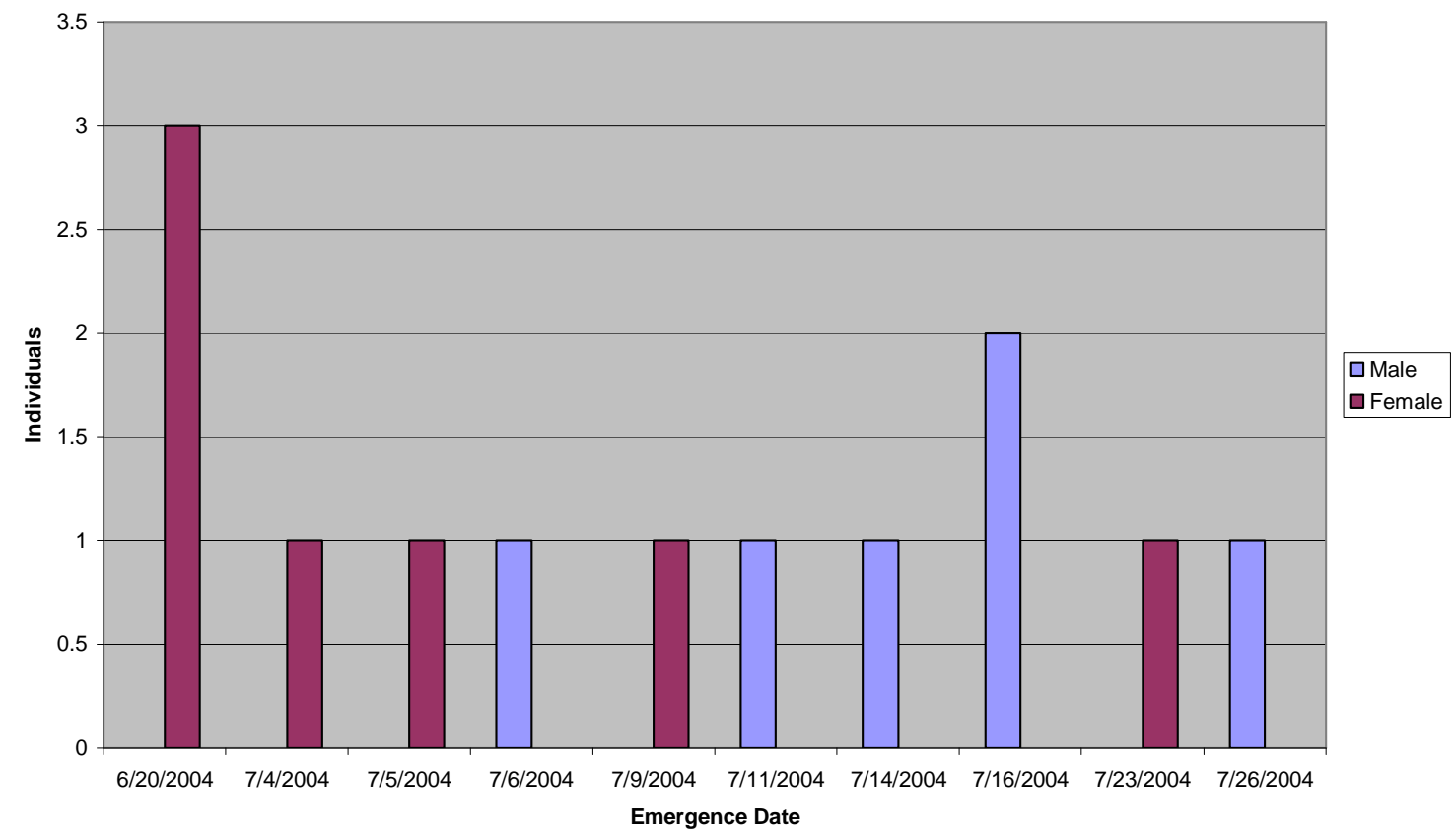

Figure 15. Quantities of male and female Hadrotrichodes waukheon reared from oleander by emergence date at Stewart's in 2004. 
Male and Female Hadrotrichodes waukheon on Stewart's Oleander 2004 by Collection Date

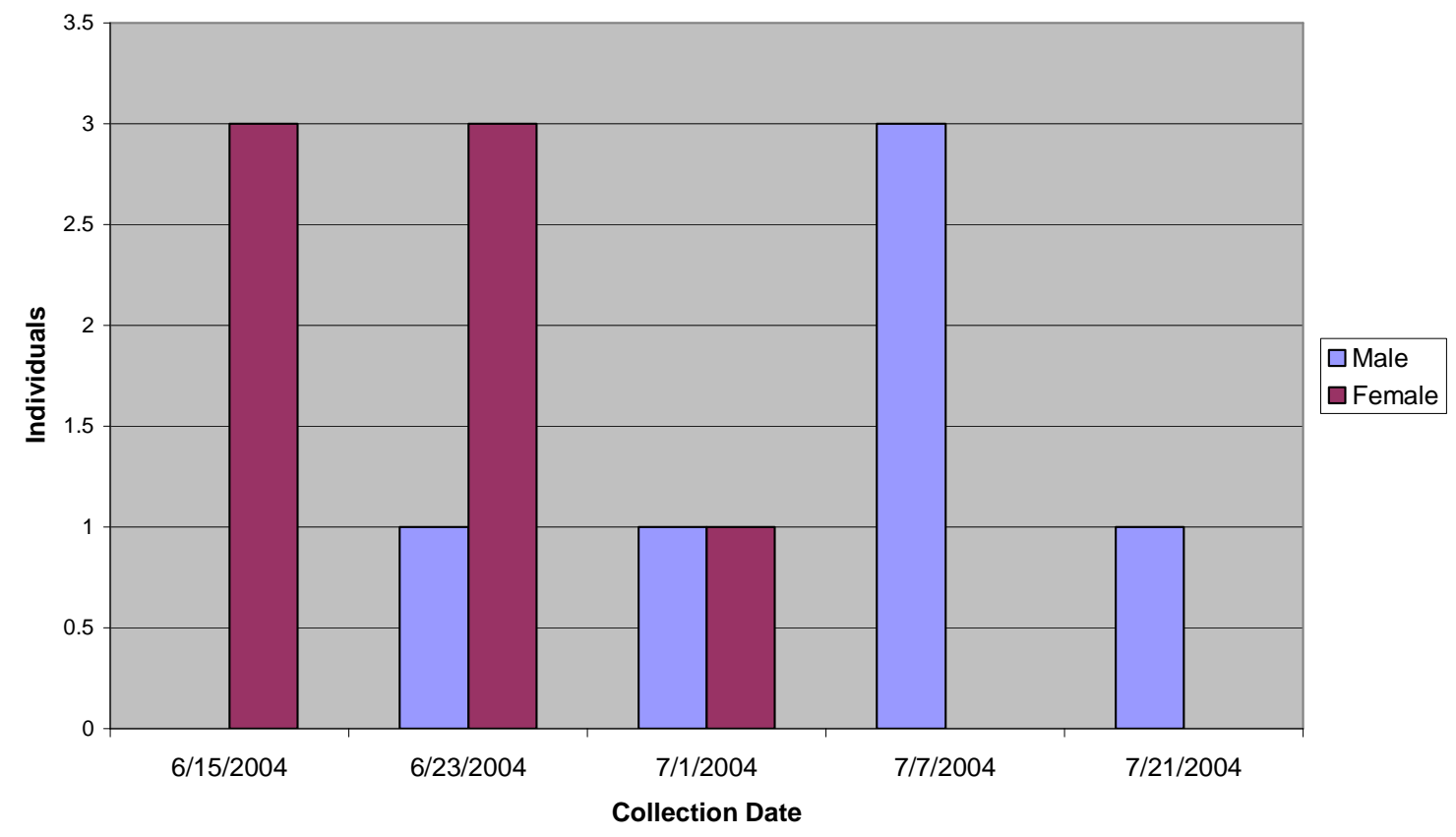

Figure 16. Quantities of male and female Hadrotrichodes waukheon reared from oleander by collection date at Stewart's in 2004. 
A change in sex ratio patterns was observed over time at the Stewart's Residence. Six out of seven parasitoids were female in the first eight sample days that parasitoids were collected. Five of six parasitoids were male in the following 21 days. Thus, females were predominant the first eight sample days and in the remaining 21 sample days more males were produced. The ratio of females to males for the entire season, respectively, was 1:0.86. The growth and development survey began before parasitism was observed, so sample dates show the first week of $H$. waukheon activity on M. gulosa on oleander, but sampling was terminated before all evidence of $H$. waukheon had disappeared. A decline in H. waukheon populations was occuring. See Discussion for more information on the sex ratio patterns. 
Parastoid collection data at Stewart's in 2004

Growth and development study at Stewart's 2004

\begin{tabular}{|c|c|c|c|c|c|c|}
\hline Date Collected & Date Emerged & Sex & Clutch & Date & Bush \# & Instar parasitized \\
\hline $6 / 15 / 2004$ & $6 / 20 / 2004$ & $\mathrm{~F}$ & $\overline{\mathrm{Q}}$ & & & \\
\hline $6 / 15 / 2004$ & $6 / 20 / 2004$ & $\mathrm{~F}$ & $Q$ & & & \\
\hline $6 / 15 / 2004$ & $6 / 20 / 2004$ & $\mathrm{~F}$ & Q & & & \\
\hline $6 / 23 / 2004$ & $7 / 23 / 2004$ & $F$ & & $6 / 23 / 2004$ & 1 & 3rd \\
\hline $6 / 23 / 2004$ & $7 / 4 / 2004$ & $F$ & & $6 / 23 / 2004$ & 2 & 4th \\
\hline $6 / 23 / 2004$ & $7 / 5 / 2004$ & $\mathrm{~F}$ & & $6 / 23 / 2004$ & 2 & 3rd \\
\hline \multirow[t]{2}{*}{$6 / 23 / 2004$} & $7 / 11 / 2004$ & $M$ & & $6 / 23 / 2004$ & 2 & 4th \\
\hline & & & & $6 / 23 / 2004$ & 2 & 5th \\
\hline $7 / 1 / 2004$ & $7 / 4 / 2004$ & $?$ & $\mathrm{R}$ & $7 / 1 / 2004$ & 1 & $3 r d$ \\
\hline $7 / 1 / 2004$ & $7 / 4 / 2004$ & $?$ & $\bar{R}$ & & & \\
\hline $7 / 1 / 2004$ & $7 / 6 / 2004$ & $M$ & & $7 / 1 / 2004$ & 1 & 4th \\
\hline \multirow[t]{3}{*}{$7 / 1 / 2004$} & $7 / 9 / 2004$ & $\mathrm{~F}$ & & $7 / 1 / 2004$ & 2 & 4th \\
\hline & & & & $7 / 1 / 2004$ & 2 & 5th \\
\hline & & & & $7 / 1 / 2004$ & 2 & 4th \\
\hline $7 / 7 / 2004$ & $7 / 14 / 2004$ & $\mathrm{M}$ & & $7 / 7 / 2004$ & 1 & $3 r d$ \\
\hline $7 / 7 / 2004$ & 7/16/2004 & $M$ & & 7/7/2004 & 2 & 4th \\
\hline \multirow[t]{6}{*}{$7 / 7 / 2004$} & 7/16/2004 & $M$ & & 7/7/2004 & 2 & 3rd \\
\hline & & & & $7 / 14 / 2004$ & 1 & 5th \\
\hline & & & & $7 / 14 / 2004$ & 1 & 4th \\
\hline & & & & $7 / 14 / 2004$ & 1 & 5th \\
\hline & & & & $7 / 14 / 2004$ & 2 & 4th \\
\hline & & & & $7 / 14 / 2004$ & 2 & 5 th \\
\hline \multirow[t]{8}{*}{$7 / 21 / 2004$} & $7 / 26 / 2004$ & $\mathrm{M}$ & & $7 / 21 / 2004$ & 1 & 4th \\
\hline & & & & $7 / 21 / 2004$ & 1 & 4th \\
\hline & & & & $7 / 21 / 2004$ & 1 & $3 r d$ \\
\hline & & & & |7/21/2004 & 2 & 4th \\
\hline & & & & $7 / 21 / 2004$ & 2 & 3rd \\
\hline & & & & $7 / 21 / 2004$ & 2 & 4th \\
\hline & & & & $7 / 21 / 2004$ & 2 & 4th \\
\hline & & & & $7 / 21 / 2004$ & 2 & 4th \\
\hline
\end{tabular}

Table 3. Parasitoids reared from Stewart's associated with parasitoids found in the survey conducted at Stewart's in 2004: Parasitoid collection data includes collection date, emergence date, sex of the parasitoid found and clutches from the Stewart's Residence associated with parasitoid information from the growth and development survey conducted at the Stewart's in 2004 including collection date, the bush number sampled, the larval stage parasitized and the number of larvae on each branch. 
Sex ratios within clutches were examined at BFE and the Stewart Residence. No apparent sex ratio patterns or changes over time were observed in the clutches (Table 4). The total number of reared females and males of Hadrotrichodes waukheon from BFE and the Stewart Residence and the total number of parasitoids emerging singly or gregariously are summarized in Table 5. Predominantly, a single $H$. waukheon adult emerged from one M. gulosa host larva. Hadrotrichodes waukheon can have up to four parasitoids emerge from one M. gulosa larva. 


\begin{tabular}{|c|c|c|c|c|c|c|c|}
\hline Branch & Location & $\begin{array}{c}\text { Host } \\
\text { Plant }\end{array}$ & Clutch Size & $\begin{array}{c}\text { Date } \\
\text { Collected }\end{array}$ & $\begin{array}{c}\text { Date } \\
\text { Emerged }\end{array}$ & F & M \\
\hline 2 & B.F.E. & oleander & Double & $6 / 8 / 2004$ & $6 / 20 / 2004$ & 1 & 1 \\
\hline 3 & B.F.E. & oleander & Double & $6 / 15 / 2004$ & $6 / 20 / 2004$ & 1 & 1 \\
\hline 4 & B.F.E. & oleander & Double & $6 / 15 / 2004$ & $6 / 20 / 2004$ & 1 & 1 \\
\hline 14 & J. Stewart & oleander & Triple & $6 / 15 / 2004$ & $6 / 20 / 2004$ & 3 & 0 \\
\hline 5 & B.F.E. & oleander & Double & $6 / 23 / 2004$ & $6 / 30 / 2004$ & 0 & 2 \\
\hline 1 & B.F.E. & oleander & Triple & $6 / 23 / 2004$ & $6 / 29 / 2004$ & 1 & 2 \\
\hline 6 & B.F.E. & oleander & Double & $7 / 1 / 2004$ & $7 / 12 / 2004$ & 1 & 1 \\
\hline 7 & B.F.E. & oleander & Quadruple & $7 / 7 / 2004$ & $7 / 11 / 2004$ & 2 & 2 \\
\hline 8 & B.F.E. & oleander & Triple & $7 / 7 / 2004$ & $7 / 12 / 2004$ & 2 & 1 \\
\hline 9 & B.F.E. & oleander & Quadruple & $7 / 7 / 2004$ & $7 / 14 / 2004$ & 2 & 2 \\
\hline 10 & B.F.E. & oleander & Triple & $7 / 7 / 2004$ & $7 / 16 / 2004$ & 2 & 1 \\
\hline 11 & B.F.E. & oleander & Triple & $7 / 14 / 2004$ & $7 / 16 / 2004$ & 2 & 1 \\
\hline 12 & B.F.E. & oleander & Triple & $7 / 14 / 2004$ & $7 / 16 / 2004$ & 0 & 3 \\
\hline 13 & B.F.E. & oleander & Triple & $7 / 14 / 2004$ & $7 / 20 / 2004$ & 3 & 0 \\
\hline 19 & B.F.E. & oleander & Triple & $9 / 15 / 2004$ & $9 / 24 / 2004$ & 2 & 1 \\
\hline Totals & \multicolumn{1}{|l|}{} & 42 & & 23 & 19 \\
\hline
\end{tabular}

Table 4. Clutch sizes and sexes within clutches of Hadrotrichodes waukheon at BFE and Stewart's on oleander in 2004.

Total number of Hadrotrichodes waukheon

71 specimens total

\begin{tabular}{|c|c|c|c|c|c|}
\hline $\begin{array}{c}\# \\
\text { Females }\end{array}$ & $\begin{array}{c}\# \\
\text { Males }\end{array}$ & $\begin{array}{c}\# \\
\text { Singles }\end{array}$ & $\begin{array}{c}\# \\
\text { Doubles }\end{array}$ & $\begin{array}{c}\# \\
\text { Triples }\end{array}$ & $\begin{array}{c}\# \\
\text { Quadruples }\end{array}$ \\
\hline 39 & 32 & 29 & 5 & 8 & 2 \\
\hline
\end{tabular}

Table 5. Total number of male and female Hadrotrichodes waukheon and quantity in each specific clutch size from BFE and Stewart's oleander in 2004. 


\section{Discussion \\ Pre-release survey}

The seven parasitoids found in the six genera of Eulophidae, Pnigalio, Closterocerus, Baryscapus, Nechrysocharoides, Hemiptarsenus and Hadrotrichodes, and one genera of Encyrtidae, Comperiella, have not provided sufficient control of M. gulosa to date; however, they can give us insights into which biological control agents may work effectively in the system. All of the parasitoids, except one, are in the family Eulophidae making it essential to investigate this family for other possible natural enemies.

A taxonomic database of the family Eulophidae was searched to find other potential natural enemies or see patterns of host use within the family. A digital catalog titled Taxapad (Noyes 2002) was used to compile genera and subfamily names of potential natural enemies. Taxapad (Noyes 2002) contains 20 different families in the hymenopteran superfamily Chalcidoidea with a total of 21,502 species. A total of 4,288 species are in the family Eulophidae. Each species of eulophid was checked to determine if it had leafminers or peelminers recorded as hosts. This list was compiled to determine potential M. gulosa and Phyllocnistis citrella Stainton natural enemies. Phyllocnistis citrella, citrus leafminer, is a microlepidoptera with similar feeding habits to M. gulosa. Phyllocnistis citrella was first detected in the United States in 1993 in Florida (Heppner 1993; Knapp et al. 1995; Gates et al. 2002) and later detected in the Imperial Valley in 2000 (Guillén et al. 2001). A survey of native parasitoids attacking $P$. citrella in the United States conducted by Gates et al. completed in 2002 showed native parasitoids to be comprised predominantly of eulophids. Since chalcidoid parasitoids of leafmining insects are often generalists, (Askew et al. 1974 and Gates et al. 2002) the parasitoids for P. citrella are likely to be similar to the natural enemies for M. gulosa. Marmara gulosa 
has no natural enemies in the San Joaquin Valley that provide population regulation in agroecosystems, making it likely for a new natural enemy to be introduced. This list (Appendix B) of parasitoids shows known host associations, and where these natural enemies might be found. The list is organized according to subfamily and location of the natural enemy. The genus name of the parasitoid is italicized and in bold. Under each genus are the scientific names of the host insect(s), followed by, if possible, its order and family and common name, see Appendix B for complete list.

Several tables have been formed to determine if there are any host use patterns using a hierarchical analysis of the taxonomic data. Eulophids were grouped according to location and host preferences. The eulophids found in California were grouped (Table 6). The biological control agents found native in California may be more adapted to climates such as those in the San Joaquin Valley. Environmental matching is an important consideration in natural enemy releases (Van den Bosch et al. 1973).

The eulophids found in states other than California were grouped (Table 7). Seventeen of the 22 described Marmara species are found in the United States (Clemens 1860, 1863; Chambers 1875; Busck 1906, 1909; Bruan 1909; Vinal 1917; Forbes 1923; DeGryse 1943; Fitzgerald 1973, 1975; Davis 1983; Guillén et al. 2001). Other than California, Marmara gulosa has only been reported in Arizona (Vinal 1917; Lockwood 1933; Wolgum 1948; Atkins 1961; Atkins 1971; Reeves 1995; Guillén 1999). All of the above factors can be included when considering releases of a new biological control agent. 


\begin{tabular}{|l|l|l|l|}
\hline Achrysocharella & Cirrospilus & Elachertus & Neochrysocharis \\
\hline Achrysocharis & Closterocerus & Euderus & Pnigalio \\
\hline Astichus & Diaulinopsis & Hadrotrichodes & Sympiesis \\
\hline Aulogymnus & Diglyphus & Hyssopus & Zagrammosoma \\
\hline Chrysocharis & \multicolumn{3}{|l}{}
\end{tabular}

Table 6. Eulophid genera occurring in California.

\begin{tabular}{|l|l|l|}
\hline Achrysocharoides & Chryptastichus & Hemiptarsenus \\
\hline Apleurotropis & Citrostichus & Minotetrastichus \\
\hline Ascotolinx & Colpoclypeus & \multicolumn{1}{|c}{} \\
\cline { 1 - 2 } & &
\end{tabular}

Table 7. Eulophids found in states other than California. 
Eulophids that only have lepidopteran leafminers and M. gulosa as hosts were grouped in Table 8 . The eulophids in Table 8 are only known to parasitize leafmining Lepidoptera. Since M. gulosa and P. citrella are leafmining Lepidoptera, the eulophids in Table 8 may be better adapted to use the two miners as hosts.

Eulophids that have additional hosts to lepidopteran leafminers and M. gulosa larvae were grouped (Table 9). The parasitoids in Table 9 are not specialized on $M$. gulosa; the lack of specialization should be considered before releases into new environments are made as the parasitoids may not focus on M. gulosa as a host and provide population regulation. Marmara gulosa is not found on certain host plant species during certain times of the year. Parasitoids that can use alternate insect hosts and host plants may be able to keep parasitoid populations high enough until M. gulosa is available, but using this characteristic alone may not be a good approach.

Table 10 includes the genera of leafmining or peelmining parasitoids, the order of their host(s), and how many different species are in each genus. Table 10 can be used to determine if there are multiple species within a genus that are potential parasitoids of $M$. gulosa, what other hosts may be used, and which genera may parasitize M. gulosa or $P$. citrella.

A study of native parasitoid establishment, in Spain, on newly invaded citrus leafminer, Phyllocnistis citrella, Vercher et al. (2005) stated all leafminers found on herbaceous plants are dipteran leafminers and all miners found on woody perennials are lepidopteran leafminers. Vercher et al. (2005) says that the majority of parasitoids of $P$. citrella came from leafminers on woody perennials whereas the parasitoids of leafminers from herbaceous plants did not transfer to $P$. citrella. Marmara gulosa has hosts of both 
woody perennial and herbaceous plant species. The Taxapad database was examined to find which parasitoid species had both lepidopteran and dipteran hosts (Table 11). Parasitoids that have both lepidopteran and dipteran hosts may be looked at further to see if they can be used as biological control agents of M. gulosa.

Several genera of eulophids were chosen for more careful examination to determine if they contain potential biological control agents for use in the San Joaquin Valley. Hadrotrichodes is one genus that warrants further research as it is already present in the San Joaquin Valley and is known to attack low density populations of $M$. gulosa. One problem with Hadrotrichodes is its apparently sporadic occurrence; following the 2004 observation only one specimen was found in 2006 . The next most desirable genera include the following: Achrysocharella, Achrysocharis, Chrysocharis, Cirrospilus, Closterocerus, Diaulinopsis, Elachertus, Hyssopus, Pnigalio, Sympiesis, and Zagrammosoma. The aforementioned genera are known to be in California and are known to use leaf mining Lepidoptera as hosts. Genera that are already in California may be better adapted to the San Joaquin Valley and increase the possibility the insect will survive as a biological control agent. Parasitoids that are already known to use leaf mining Lepidoptera as hosts may be more adapted to the life habits of M. gulosa and therefore be more effective biological control agents. The third most desireable group of genera includes Mestocharella and Proacrias. These two genera are known to parasitize leaf mining Lepidoptera in the United States in states other than California.

One species in the genus Citrostichus Boucek is being considered as a biological control agent for importation from Spain to California. This genus contains only two species. The host list for this genus includes Phyllocnistis citrella and Trioza obsolete 
(Hemiptera, Triozidae: Jumping plantlice). The distribution is in areas of Asia, India, the Afrotropics, and the Middle East. Citrostichus phyllocnistoides Narayanan has been introduced as a biological control agent into Australia, Greece, India, Spain and Florida in 1995, 1997, 1996, 1996 and 1994 respectively (La Salle et al. 1997; Noyes 2002; Vercher et al. 2005). 


\begin{tabular}{|l|l|l|}
\hline Genus & Host(s) & $\begin{array}{l}\text { \# of } \\
\text { parasitoid } \\
\text { species }\end{array}$ \\
\hline Ascotolinx & Phyllocnistis citrella (Lepidoptera:Gracillariidae) & 2 \\
\hline Cryptastichus & Phyllocnistis citrella (Lepidoptera:Gracillariidae) & 1 \\
\hline Hadrotrichodes & Marmara gulosa (Lepidoptera: Gracillariidae) & 1 \\
\hline Mohaniella & Lepidopteran leaf miner & 1 \\
\hline Ryhonos & $\begin{array}{l}\text { Acrocercops chionosema and Phyllonorycter messaniella } \\
\text { (leaf mining Gracillariidae) }\end{array}$ & 1 \\
\hline Sarasvatia & Stigmella ipomoella (Lepidopidoptera:Nepticulidae) & 1 \\
\hline Semielacher & Phyllocnistis citrella (Lepidoptera:Gracillariidae) & 2 \\
\hline Zaommomentedon & Phyllocnistis citrella (Lepidoptera:Gracillariidae) & 3 \\
\hline
\end{tabular}

Table 8. Eulophids with only Lepidopteran leafminers as a host.

\begin{tabular}{|l|l|l|l|l|}
\hline Achrysocharella & Citrostichus & Elachertus & Mestocharella & Quadrastichus \\
\hline Achrysocharis & Closterocerus & Elasmus & Minotetrastichus & Ratzeburgiola \\
\hline Achrysocharoides & Colpoclypeus & Galeopsomyia & Neochrysocharis & Shardiella \\
\hline Apleurotropis & Demmockia & Hemiptarsenus & Proacrias & Stenomesius \\
\hline Astichus & Diaulinopsis & Horismenus & Omphale & Sympiesis \\
\hline Aulogymnus & Diglyphus & Hyssopus & Pediobus & Tetrastichomyia \\
\hline Chrysocharis & Dicladocerus & Kraytoysma & Pleurotroppopis & Tetrastichus \\
\hline Cirrospilus & Euderus & Meruana & Pnigalio & Trisecodes \\
\hline
\end{tabular}

Table 9. Eulophids with additional hosts to Lepidopteran leafminers. 


\begin{tabular}{|l|l|l|}
\hline Genus & Host(s) & \# of parasitoid species \\
\hline Achrysocharella & $\begin{array}{l}\text { leaf mining Coleoptera, Diptera, Lepidoptera, \& } \\
\text { Hymenoptera }\end{array}$ & 45 \\
\hline Achrysocharis & leaf mining Coleoptera, Diptera, and Lepidoptera & 63 \\
\hline Achrysocharoides & $\begin{array}{l}\text { larva of Lepidoptera in concealed situations and a } \\
\text { Diptera (Tachinidae) }\end{array}$ & 59 \\
\hline Chrysocharis & leaf mining Diptera, Lepidoptera, \& Hymenoptera & 63 \\
\hline Cirrospilus & hosts hidden in plant tissue (miners, rollers, and galls) & 24 \\
\hline Closterocerus & leaf mining Diptera, Lepidoptera, \& Hymenoptera & 125 \\
\hline Diaulinopsis & leaf mining Diptera and Lepidoptera & 5 \\
\hline Diglyphus & leaf mining Diptera & 52 \\
\hline Elachertus & larva of Lepidoptera in concealed situations & 186 \\
\hline Hemiptarsenus & leafminers, mostly Diptera & 67 \\
\hline Hyssopus & larva of Lepidoptera in concealed situations & 18 \\
\hline Meruana & leaf mining Diptera & 4 \\
\hline Mestocharella & leaf mining Coleoptera, Diptera, and Lepidoptera & 11 \\
\hline Minotetrastichus & leaf mining Coleoptera and Hymenoptera & 16 \\
\hline Pnigalio & leaf mining Coleoptera, Diptera, and Lepidoptera & 99 \\
\hline Proacrias & leaf mining Coleoptera, Diptera, and Lepidoptera & 7 \\
\hline Shardiella & Agromyzid miners & 1 \\
\hline Sympiesis & leaf mining Coleoptera and Lepidoptera & 195 \\
\hline Zagrammosoma & leaf mining Diptera and Lepidoptera & 26 \\
\hline
\end{tabular}

Table 10. The genus of parasitoids with mining hosts in addition to Lepidoptera, the hosts they are found on, and the number of species within each genus.

\begin{tabular}{|l|l|l|}
\hline Pnigalio flavipes & Sympiesis sericeicornis & Closterocerous lyonetiae \\
\hline Pnigalio maculipes & Sympiesis xanthostoma & Closterocerous tekensis \\
\hline Pnigalio minio & Hemiptarsenus ornatus & Closterocerous trifasciatus \\
\hline Pnigalio crassinervis & Hemiptarsenus unguicellus & Closterocerous utahensis \\
\cline { 1 - 2 } Diglyphus isaea & Hemiptarsenus zilahisebessi & Closterocerous violaceus \\
\cline { 1 - 2 } Diglyphus minoeus & Closterocerous cinctipennis & \multirow{2}{|}{} \\
\cline { 1 - 2 } Sympiesis acalle & Closterocerous germanicus & \\
\cline { 1 - 2 } & \multicolumn{2}{|l}{} \\
\cline { 1 - 2 } &
\end{tabular}

Table 11. The genus and species of parasitoids with both dipteran and lepidopteran hosts. 


\section{Cirrospilus coachellae releases}

Cirrospilus coachellae appears to be an excellent disperser, as all recoveries have been observed away from release points (Speidel 2004). The larger the release group of C. coachellae, the more likely there will be observable parasitism (Speidel 2004). Efforts to conduct releases of $C$. coachellae have been hindered by M. gulosa colony problems and the limited numbers of $C$. coachellae produced for releases. Marmara gulosa has been difficult to rear on citrus fruit due to the lack of suitable fruit for oviposition throughout the year as well as citrus fruit becoming desiccated to the point where $M$. gulosa cannot survive (B. Grafton-Cardwell and Y. Ouyang, pers. comm. 2004). Marmara gulosa has been successfully reared on zucchini throughout the year, but $C$. coachellae only does well for two generations and then the number of parasitoids drops significantly until the colony dies out (B. Grafton-Cardwell and Y. Ouyang, pers. comm. 2005). The reason for the decline in C. coachellae numbers is unknown. Due to the lack of parasitoids being reared, release numbers were small and have not been as wide spread as was hoped for the past five field seasons. There is a possibility that other species from the family Eulophidae were in the vials of field collected parasitoids from Neil Smart. The other species released was most likely Closterocerus utahensis Crawford.

Cirrospilus coachellae may not be able to establish in the San Joaquin Valley due to its relatively high lower developmental threshold. Guillén et al. (2003) showed the lower developmental threshold for C. coachellae to be at $14.1^{\circ} \mathrm{C}$ and the upper developmental threshold to be at $36.7^{\circ} \mathrm{C}$. The average high during summer in the San Joaquin Valley is $35.9^{\circ} \mathrm{C}$ while the average low for the winter is $2^{\circ} \mathrm{C}$. After two field seasons of monitoring, 2002-2004, there have been no recoveries of $C$. coachellae after 
the winter season. The average low in the San Joaquin Valley is lower than the lower developmental threshold of $C$. coachellae and may be why the parasitioid has not been able to establish. Cirrospilus coachellae however; may be a good parasitoid for augmentative biological control.

A pheromone lure for M. gulosa has been developed by Dr. Jocelyn Millar at the University of California, Riverside. Pheromone lures have been field tested in the San Joaquin Valley by Beth Grafton-Cardwell and her staff as well as by David Headrick and his graduate students from the end of 2003 to the present. Effective pheromone trapping of M. gulosa will allow growers and PCA's to know when adult flights occur and therefore make releases of $C$. coachellae more effective.

\section{Oleander, Nerium spp, Monitoring}

The oleander studies conducted at BFE and the Stewart Residence show larval development relative to parasitism and general population dynamics of $M$. gulosa. The growth and development graph from BFE oleander (Fig. 7) shows the first instar larvae increasing from week four until a decline began at week eight, extending to week ten. On July 1, 2004 (week 11) the numbers of first instar larvae increased for a second time. The second increase of first instar larvae on July 1, 2004 may indicate a second flight generation. Marmara gulosa is multivoltine, meaning it produces more than one generation in a year. Each generation requires a certain amount of accumulated degree days to complete a lifecycle from egg to adult. A second flight would indicate a second generation of $M$. gulosa larvae becoming adults that are able to reproduce and lay eggs. The third instar larvae showed a relatively large increase in number on July 7, 2004 (week 12). However, the oleander branches were heavily mined at this point in time 
making distinction between mines and mine sizes difficult. Thus, the number of third instar larvae may be high due to lumping with fourth instar larvae. On July 1, 2004 the first observation of parasitoid pupae was recorded. The increase in the number of individual parasitoid pupae correlated with the increase of the number of individual fourth instar M. gulosa larvae. Hadrotrichodes waukheon adults parasitized fourth instar M. gulosa larvae most frequently (Fig.8), and the way the population curves of $H$. waukheon and M. gulosa relate to each other supports this evidence.

At the Stewart's Residence (Fig. 10) trends in larval development were observed. The first week, May 5, 2004, the number of first instar larvae was at the highest level during the study and decreased gradually to zero by week five, June 2, 2004. On June 15, 2004, week six, the number of individual first instar larvae increased from zero to two. The small number of samples prevents making any definitive conclusions, but may indicate another generation as the timing is similar to BFE. Parasitoid pupae were first observed on June 23, 2004, week seven. An increase in third instar larvae occurred on July 1, 2004, week eight. Oleander branches were heavily mined at this time making it difficult to distinguish between individual mines and mine size, which is used to estimate the larval instar. Thus, some third and fourth instars may have inadvertently been lumped together. The results indicated that the number of individual parasitoid pupae closely followed the number of individual fourth instar M. gulosa larvae observed (Fig. 8 \& 11).

According to Guillén et al. (2003) the preliminary lower developmental threshold for M. gulosa is $14.1^{\circ} \mathrm{C}$. Based on the lower developemental threshold and the 30 year historical averages for temperature, a degree day model was developed to predict adult flights and therefore generations. The adult flights occur at 580, 1160, 1740, 2320, 2900, 
and 3480 degree days calculated in Fahrenheit degrees (B. Grafton-Cardwell 2005). A single sine degree day calculator in Fahrenheit was set up by Greg Montez, UCKAC, using $58^{\circ} \mathrm{F}$ for the lower developmental threshold with no upper developmental limit. Weather data was used from the Lindcove field station for 2004. According to the degree day information, parasitism occurred between the second and third M. gulosa flights in 2004. Parasitism activity between the second and third $M$. gulosa flights is logical for two reasons. First, because there is a greater abundance of late instar M. gulosa larvae. Secondly, it takes time for the parasitoids to find their hosts and build up numbers. Asynchronicity of pest/parasitoid complexes are common in SJV, for example California red scale and Aphytis melinus. Hadrotrichodes waukheon are idiobiont parasitoids, meaning they permanently paralyze or kill their host once the host has been parasitized. Personal observation of the host while rearing the parasitoids showed the M. gulosa larvae do not move once parasitized. The stage the larva is in when parasitized is the same stage when sampled.

\section{$\underline{\text { Parasitism on Oleander }}$}

The gregarious parasitoid, Hadrotrichodes waukheon, was reared from M. gulosa larvae on oleander and on Melogold grapefruit. Curated $H$. waukheon specimens at UC Riverside were reared from M. gulosa larvae on grapefruit by Marta Guillén in 2003. In our studies, one to four adult $H$. waukheon were observed to emerge from one $M$. gulosa larva on oleander. The quantity of $H$. waukheon that emerged from $M$. gulosa larvae on grapefruit was not noted by Guillén. Hadrotrichodes waukheon can be distinguished from other parasitoid pupae by meconial position (Fig. 17). Meconial deposits are 
formed into two, oval-shaped pellets, one on either side of the base of the pupa.

Hadrotrichodes waukheon appears to be an ectoparasite of M. gulosa larva. From our samples $H$. waukheon parasitized third through fifth instar peelminer larvae with fourth instar larvae being the most predominantly parasitized (Fig. 8 and Fig. 11). The possibility that $H$. waukheon, already present in the San Joaquin Valley, could be used as a biological control agent makes a complete description of this eulophid essential. 


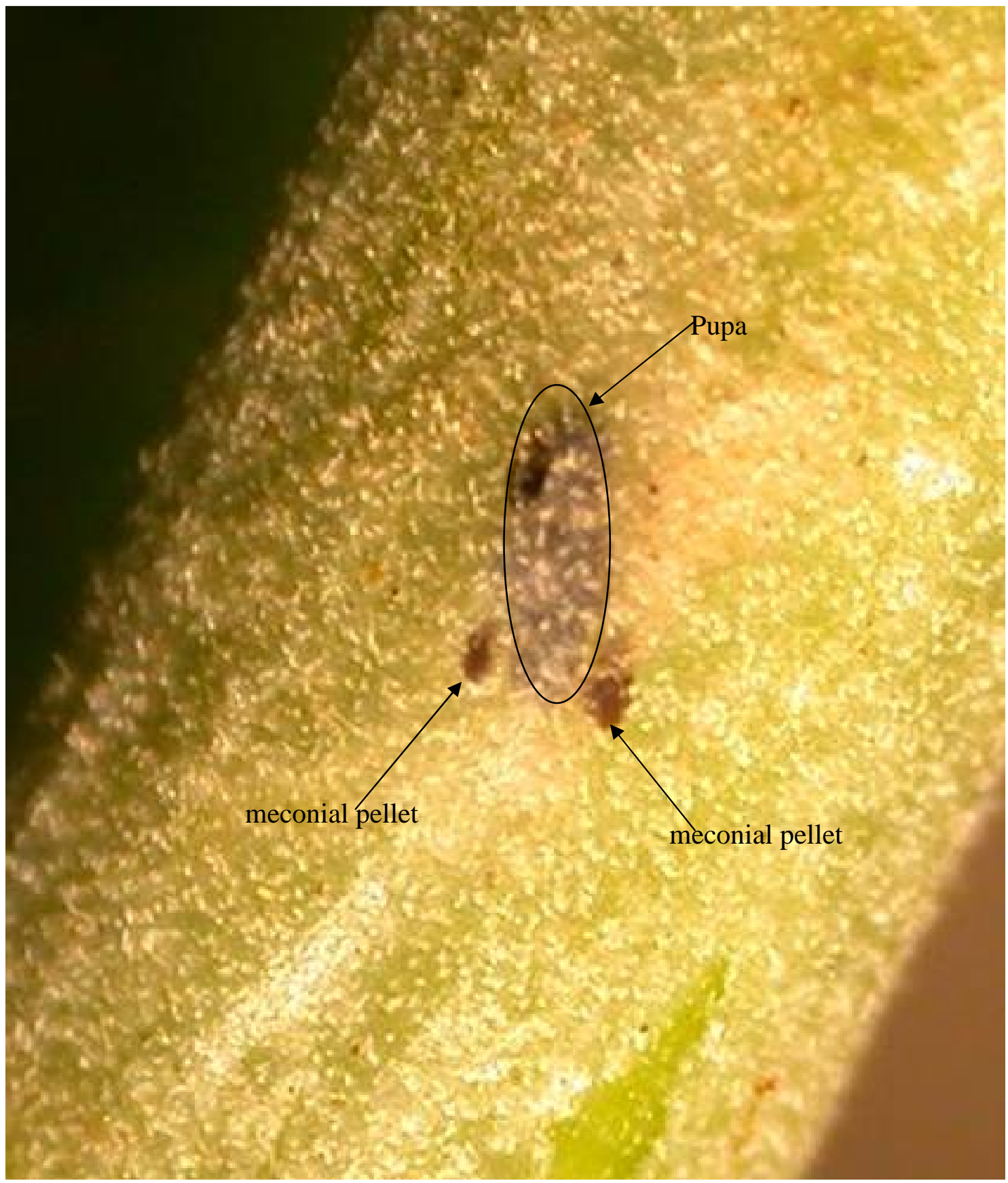

Figure 17. Hadrotrichodes waukheon meconial pellet arrangement. 
There was an average of $6.65 \%$ parasitism of M. gulosa at BFE and an average of $12 \%$ parasitism of M. gulosa at the Stewart's residence in 2004. Percent parasitism in 2004 at BFE calculated weekly ranged from 5.1 to $18.2 \%$. Parasitism began on June 26, 2004 and gradually increased until the end of the study. Parasitism levels steadily increased as the most desireable $M$. gulosa stages increased, third through fifth instars (Figs. 7 \& 9). Percent parasitism calculated weekly at Stewart's Residence in 2004 ranged from 9.1 to $45 \%$. Parasitism levels directly followed the M. gulosa population levels (Figs. $10 \& 12$ ) once parasitism began. Previous to 2004 no parasitoids had been recorded attacking M.gulosa on oleander. Possible reasons why H. waukheon was found parasitizing M. gulosa on oleander in 2004 include the following: Hadrotrichodes waukheon may be a generalist parasitoid in the San Joaquin Valley that found M. gulosa to be a suitable host in 2004. Members of the superfamily Chalcidoidea that parasitize leafminers are usually generalists with respect to the hosts they are associated with (Askew et al. 1974 and Gates et al. 2002). Parasitoids that permanently paralize or kill their host during attack, idiobionts, are usually generalists as well (Askew and Shaw 1974 and Gates et al. 2002). Hadrotrichodes waukheon exhibits both these generalist traits. In 2005 there was a rapid and sustained temperature increase in the the San Joaquin Valley during the second flight of M. gulosa moths. The high temperatures resulted in larval mortality of M. gulosa (Melissa O'Neal, pers. comm. 2005). The lack of suitable hosts for $H$. waukheon may have contributed to its localized disapearance. The September 8, 2005 search by two people for H. waukheon on oleander for ca. 20 mintues at both BFE and the Stewart Residence yielded no observations of $H$. waukheon. The reason for this may be due to high temperatures killing the larvae of M. gulosa when 
H. waukheon may have begun to establish (Figure 18). According to the growth and development studies conducted on oleander in 2004 (Figs. 7 \& 10), H. waukheon parasitized M. gulosa between the second and third flights of adult $M$. gulosa moths when many third and fourth instar larvae were present in 2004.

7 Day Average High Temperatures for Falls 2003 to 2005

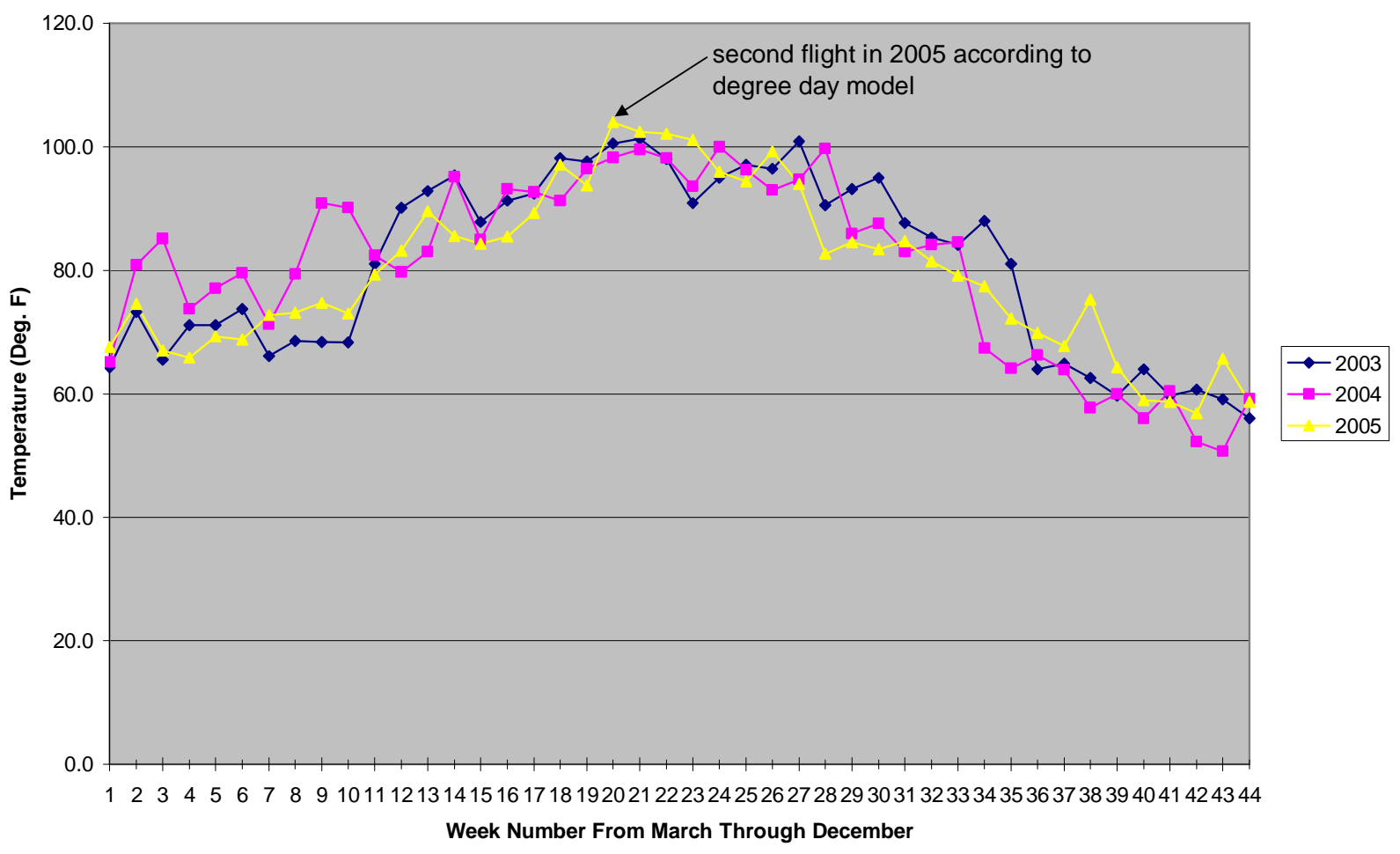

Figure 18. Average high temperatures from March through December for 2003, 2004 and 2005 at the Lindcove Field Station. 


\section{The Origin of Marmara gulosa}

According to a literature review by Cornell and Hawkins (1993), parasitism is usually lower on introduced insect herbivores than native insect herbivores. Native parasitoids species can parasitize introduced herbivores, but the diversity of parasitoids is always greater in the native area of the introduced herbivore (Cornell et al. 1993 and Schönrogge et al. 1995). An example of parasitoid diversity being lower in areas not native to an insect herbivore is with Phyllocnistis citrella Stainton (Lepidoptera: Gracillariidae). Phyllocnistis citrella is a widespread herbivorous pest from southeast Asia (Heppner 1993 and La Salle et al. 1997) that has spread to areas of the Mediterraean, South and Central America and the United States (Cornell et al. 1993 and Schönrogge et al. 1995). None of the areas where $P$. citrella has been introduced has a greater diversity of parasitoids than its area of origin in Asia. However, the parasitoid information from Cornell et al. (1993) and Schönrogge et al. (1995) do not fit with the origin hypothesis of $M$. gulosa being aggressive on citrus in California. If the origin of M. gulosa, aggressive on citrus, is from Mexico, the parasitoid complex should be more diverse in Mexico than in the San Joaquin Valley. Dr. Headrick, Sage Finch, and Paul Semet have yet to observe this in four separate visits to Mexico over three years. When Dr. Headrick, Sage Finch, and Paul Semet went to Mexico, there was little evidence of parasitism and M. gulosa was hard to find on citrus. In November of 2002 a research trip inspecting 13 field sites in Mexico showed little M. gulosa damage in a Ruby Red grapefruit orchard, two citrus orchards, and a willow grove near an orchard. No mining damage was observed on tree tobacco and only a few parasitoids were found. In September of 2003 nine field sites were observed in Mexico. Overall M. gulosa damage 
was low. One person observed four infested fruit in one hour at one orchard, and in two orchards with one person searching observed eight infested fruit in an hour. An empty solitary parasite pupa in an old $M$. gulosa larva was observed on grapefruit. On November 3, 2004 a Rio Red grapefruit orchard was examined in Mazocoba, Mexico. Only one in ten trees had mining activity on one to three fruit with no parasitism observed. On November 4, 2004 near La Ciudad de Obregon approximately $70 M$. gulosa larvae were collected on oleander with no observations of parasitism. From observations in Mexico and the San Joaquin Valley, parasitoid complexes are greater in the San Joaquin Valley. Observations by graduate students and staff at UC Riverside show parasitoid complexes to be greater in the Coachella Valley (Guillén 2003, K. Godfrey and P. Semet, pers. comm. 2004) than the San Joaquin Valley. Based on parasitoid diversity alone the suggested center of origin for M. gulosa is in the Coachella Valley; however, additional information including genetic studies, will be necessary to fully determine the area of origin of M. gulosa.

Beth Grafton-Cardwell, her staff, Dr. Headrick, and his graduate students, and students and staff at UC Riverside collected M. gulosa from Mexico, the San Joaquin Valley, and the Coachella Valley on oleander, pepper, willow, grapefruit, cotton, Amaranthus, red globe grape, Fukumoto navels, Powell oranges, wisteria, and zucchini for genetic studies. The cytochrome oxidase (COI) ribosomal gene region codes for proteins and is highly conserved. For this reason it is used to discern differences in insects at the species level (D. Vickerman, unpublished data). According to the genetic studies conducted by Vickerman and Van Nort the COI gene region shows samples of $M$. 
gulosa from Mexico and the San Joaquin Valley to be the same, but different from $M$. gulosa in the Coachella Valley.

Oleander is a host plant in the San Joaquin Valley and evidence of mining on the thick woody growth indicates mining activity was present for at least ten years if not longer based on scars observed on trunks 10.2-15.2 centimeters thick. Two PCA's, Jim Stewart and Jim Gorden (pers. comm. 2002) reported that M. gulosa has been in the San Joaquin Valley for a long time and has been an occasional sporadic pest. Genetic studies showed M. gulosa on oleander with old scarring to be identical to M. gulosa on navels, grapes, peppers, and grapefruit (D. Vickerman, unpublished data 2005). The expectation is that there should be some distinction between strains of $M$. gulos $a$ on oleander and willow and the new host plants, like citrus or bell pepper, if M. gulosa, aggressive on citrus, is truly an introduced pest population. Current genetic studies showed M. gulosa to be identical on all host plants from the San Joaquin Valley and Mexico but different from M. gulosa in the Coachella Valley (D. Vickerman, unpublished data 2006). A possible reason for M. gulosa in the San Joaquin Valley to be the same as found in Mexico is the citrus aggressive M. gulosa may have been able to out compete M. gulosa populations native to the San Joaquin Valley. The lack of parasitoid diversity in Mexico confounds the idea that M. gulosa aggressive on citrus was imported from Mexico. A greater degree of testing will be required to determine if the San Joaquin Valley $M$. gulosa is a "native invasive," an insect native to the system that expands its host range and becomes a pest or an invasive strain from Mexico whose ultimate origin may be unknown. Powell (1980) did find that Microlepidoptera, including Gracillariidae, have expanded their host range onto at least 70 different plant families. Oviposition mistakes, 
escape from natural enemies, and/or unsuitable conditions or locations of original host plants could lead to the host range expansion (Jaenike 1990; Thompson et al. 1991; Pilson 1999). Pilson (1999) says that if a novel host plant allows escape from parasitism, and the benefit of escaping parasitism outweighs any physiological difficulty, the insect may adapt to the novel host plant, then the escape from natural enemies will encourage host range expansion. Marmara gulosa has incorporated many new and chemically diverse host plants into its diet. Thus far M. gulosa has escaped a level of parasitism which has decreased population levels. Jaenike (1990) argues that there is little evidence which supports the theory that escape from natural enemies has an effect on increased diet breadth. While it seems M. gulosa has escaped natural enemies that are able to decrease their populatins in the San Joaquin Valley, there is no conclusive evidence that escape from natural enemies is the reason $M$. gulosa expanded it's host range.

\section{Improved Methods for Rearing and Curation}

A total of 14 parasitoids, other than $H$. waukheon, were reared from citrus. Approximately 40 parasitoids were collected, but many did not emerge or were lost. A better way to rear parasitoids from citrus would be to dissect the parasitoid out of the rind and put it into a small glass vial (Guillén 1999 and Speidel 2004). The vial should be closed with a piece of cotton and have a small line of honey put on the side of the vial as a food source (Guillén 1999 and Speidel 2004).

The reason for the poor preservation of the $H$. waukheon specimens from oleander was due to improper killing methods and improper use of HMDS. Parasitoids need to be killed in 70-80\% EtOH (J. Heraty et al. 1998). Specimens then need to be dehydrated to $100 \% \mathrm{EtOH}$ by transferring them into increasing concentrations of $\mathrm{EtOH}$ in $10 \%$ 
increments for $1 \frac{1}{2}$ hour each (D. Headrick, pers. comm. 2005). Once the specimens are dehydrated to $100 \% \mathrm{EtOH}$, the EtOH needs to be replaced by HMDS and soaked twice for $1 / 2$ hour each time in a covered glass vial or dish (Heraty et al. 1998). After the second soak, the remaining HMDS is poured off and the specimen needs to be put under a fume hood until thoroughly dried (Heraty et al. 1998). A brass screen can be placed over the vial or dish to keep the specimen(s) in the container (Heraty et al. 1998). Safety precautions using HMDS should be followed according to the label. Specimens then need to be card mounted using diluted white glue or shellac gel (J. Heraty, pers. comm. 2004 and R. Burkes, pers. comm. 2004).

\section{$\underline{\text { Search for Natural Enemies on Host Plants Other Than Citrus and Oleander }}$}

The single parasitoid collected from cotton was not externally visible; this may mean that there are other parasitoids in the system that have gone unnoticed. This discovery warrants further investigation of parasitoids on host plants other than oleander and citrus. A possible way to obtain parasitoids not visible externally is to carefully open mines of M. gulosa larvae on host plants and look for parasitoid pupae or collect plant material and wait for parasitoid emergence.

\section{$\underline{\text { Sex Ratios, Clutch Sizes, and Frequency of Parasitism on Oleander }}$}

Sex ratios are extremely variable among insects exhibiting haplodiploidy (Doutt 1964). At the Stewart Residence the occurrence of more females than males at the beginning of the season followed later in the season by more males than females may be indicative of a pattern. Sex ratios may provide insight into how well established the natural enemies are in an area or if there is some sort of environmental change being 
reflected in sex ratios (Wrensch et al. 1993 and Otto et al. 2001). In laboratory studies Guillén et al. (2003) found C. coachellae to be female biased for 23 days and then male biased after that time. No explanation was provided as to why this occurred; there were no obvious environmental changes. Sex ratios of $H$. waukheon were unknown previous to 2004. Hadrotrichodes waukheon populations that are first observed to exploit a new host may start by producing predominantly females and switch to producing more males. The progression of the field season (changes in day length) could trigger a response in females to produce more males. Also, size and qualiy of the host may influence the number of males produced.

\section{$\underline{\text { Cultural Control Methods }}$}

Cultural control methods may help, but probably can not control populations of M. gulosa alone. Since we know M. gulosa is attracted to certain varieties of navels, grapefruit, and pummelos, these susceptible citrus varieties should be avoided when planting a new grove. M. gulosa has many host plants (Guillén 1999; Guillén et al. 2001; Speidel 2002). A grower may be able to decrease M. gulosa populations by removing host plants around the area (Reeves 1995). Ornamental oleander bushes are a host for $M$. gulosa, but have just recently been discovered as a source for natural enemies. Removing oleander bushes may take away possible sources of infestations of M. gulosa, but may also remove an important source for natural enemies, like H. waukheon.

Marmara gulosa may overwinter or pupate on leaf litter in citrus. Removing the leaf litter underneath trees will take away a possible place for the M. gulosa to overwinter and/or pupate. Sucker growth on citrus trees provides a continuous resource upon which M. gulosa will feed. Removing all suckers on the tree would take away another resource 
for M. gulosa to consume. Removing all fruit upon harvest is also a good way to prevent overwintering sites (Grafton-Cardwell, pers. comm. 2003). 


\section{Conclusions}

Knowledge about the biology of a pest is essential to create an effective biological control plan. Lack of knowledge about generation times, host shifting, and migration make it very difficult to formulate an effective plan to control M. gulosa. The degree day models, currently being worked on by Melissa O'Neal, effective pheromone lures for trapping, and predictions on when and which host plants will be targeted will help formulate an integrated management plan. When flight times are determined with the use of pheromone lures, parasitoids such as $C$. coachellae can be augmentatively released. Knowledge of host plant preferences of $M$. gulosa throughout the season would allow parasitoids to be released into areas where they are most effective.

Natural enemies remain a viable option for control of $M$. gulosa populations. Cirrospilus coachellae has not been observed to overwinter in the San Joaquin Valley, but may be used in an augmentative biological control program. Hadrotrichodes waukheon may be a viable biological control agent for control of M. gulosa populations. Hadrotrichodes waukheon may be able to be reared on M. gulosa laboratory colonies and be released onto citrus. The lack of appearance of $H$. waukheon in 2005 prevented rearing efforts. Since $H$. waukheon may be a generalist parasitoid it might have problems in an augmentative biological control program. In a study of generalist parasitoids versus specialized parasitoids of the cassava mealybug, a generalist parasitoid was able to disperse and better search for the cassava mealy bug than a specialized parasitoid (Bertschy et al. 2001). A generalist parasitoid used in an augmentative biological control program is Aphytis melinus (Hymenoptera: Aphelinidae) (Flint et al. 1998). Aphytis melinus parasitizes several species of armored scales (Flint et al. 1998). Aphytis melinus 
is used in commercial settings to control California Red Scale, Aonidiella aurantii (Maskell), (Homoptera: Diaspididae) (Flint et al. 1998). Despite the fact that A. melinus is a generalist, it is still an effective biological control agent against specific pests. A generalist can find different food sources throughout the year keeping population numbers up, and may provide control of other insect pests. The only way to determine the efficacy of $H$. waukheon would be to perform host specificity tests.

The study by Vercher et al. (2005) on the recruitment of native natural enemies from woody perennials for $P$. citrella concludes that the parasitoids from hosts on the woody perennials did not provide sufficient control of the newly invaded pest. Even though ten different native parasitoids were observed parasitizing $P$. citrella (Vercher et al. 2005), there was not sufficient control and a classical biological control program was thus implemented. In a contrasting study, La Salle et al. (1997) stated that areas in the New World invaded by $P$. citrella were controlled the same or better with native parasitoids than with the introduced parasitoid, Ageniaspis citricola Logvinovskyay (Hymenoptera: Encyrtidae). There have been ca. 80 parasitoid species that have been reared from P.citrella world wide and many of them have moved onto $P$. citrella as it has dispersed into new areas (Schauff et al. 1998). New parasitoids of $P$. citrella may transfer to M. gulosa since they are both gracillariid moths, share some of the same host plants and chalcidoid parasitoids of leafming insects are often generalists (Askew et al. 1974 and Gates et al. 2002). 
Appendix A. Maps of field locations in the San Joaquin Valley. 


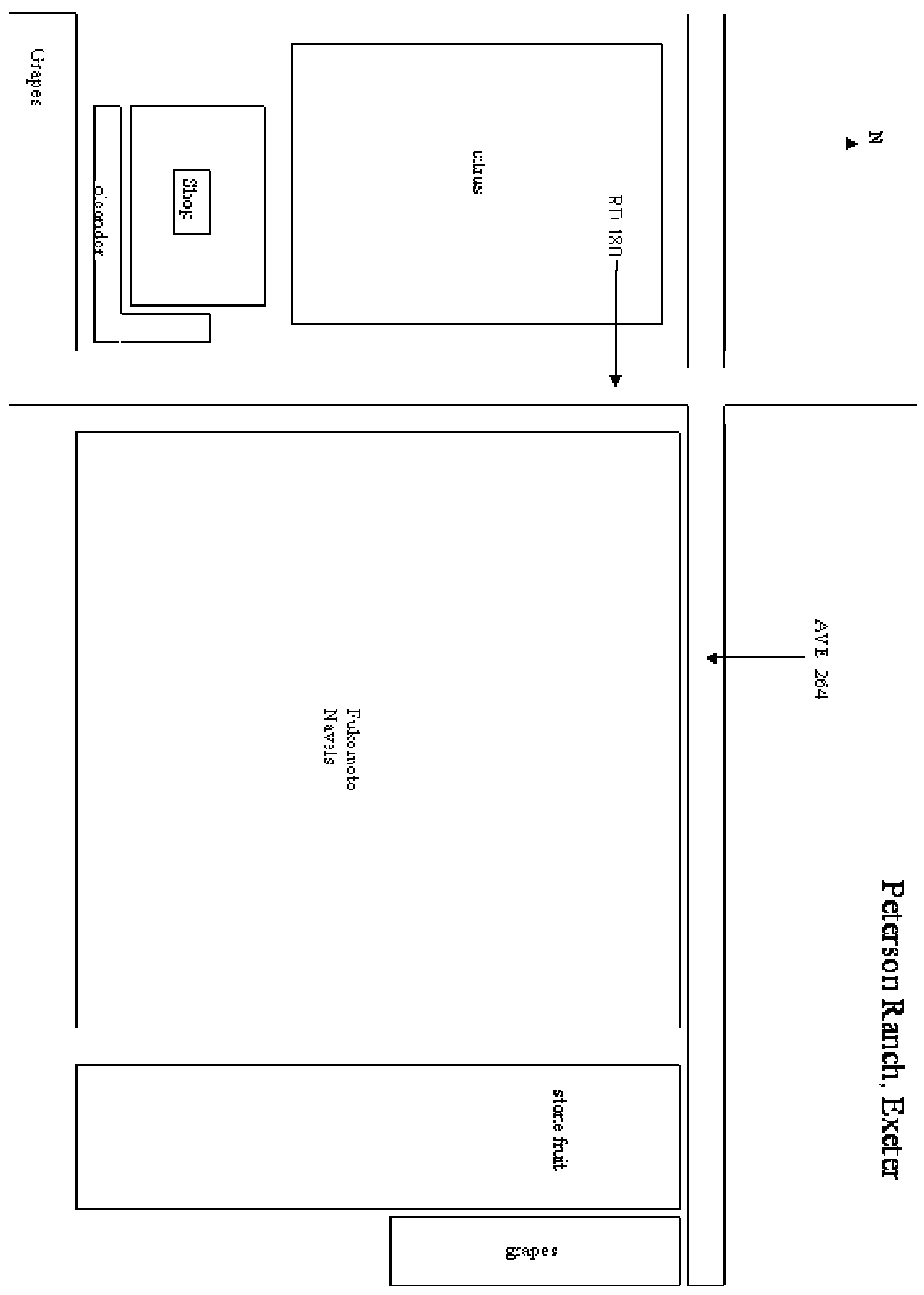

Map 1. Peterson Ranch 


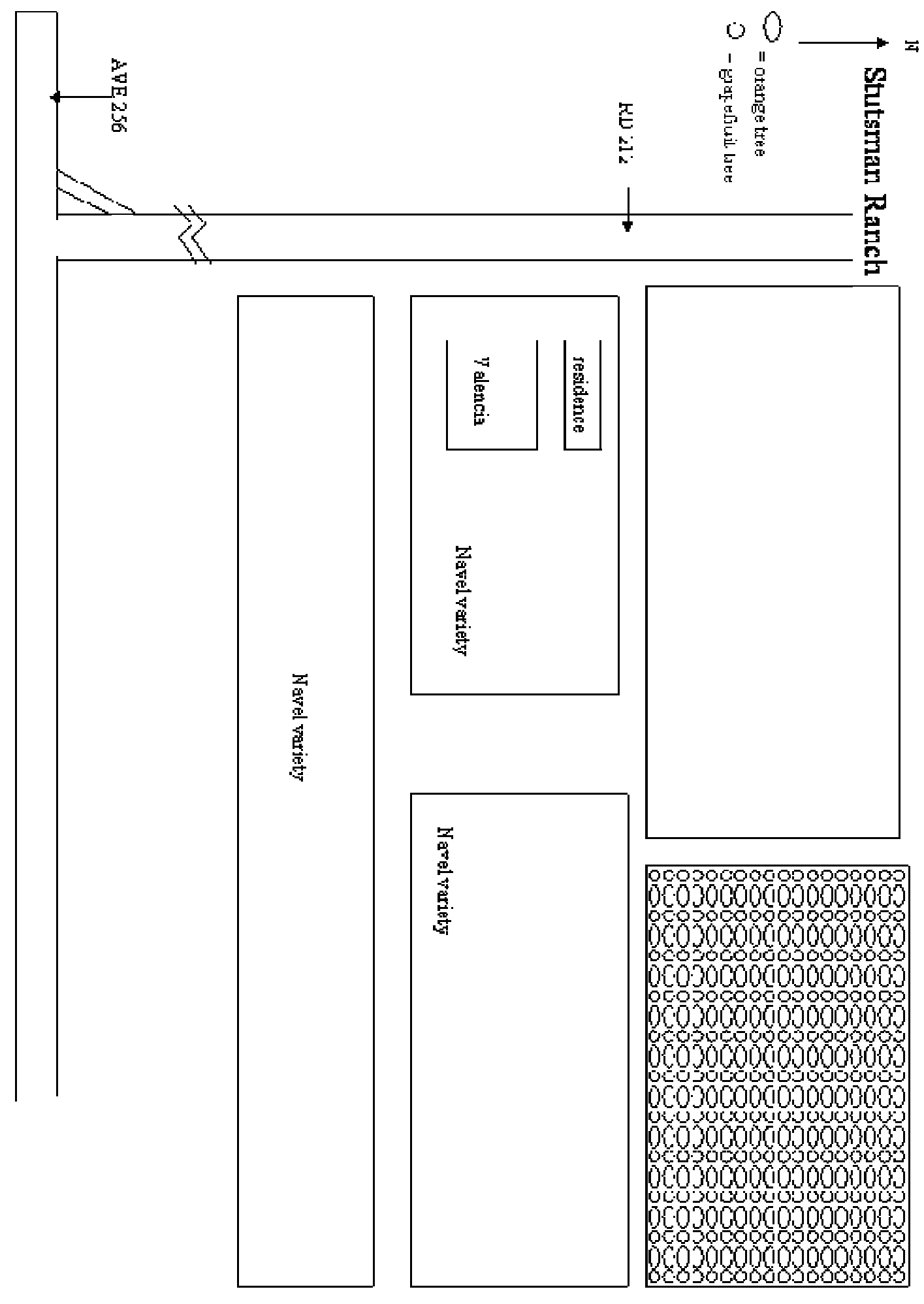

Map 2. Stutsman Ranch 


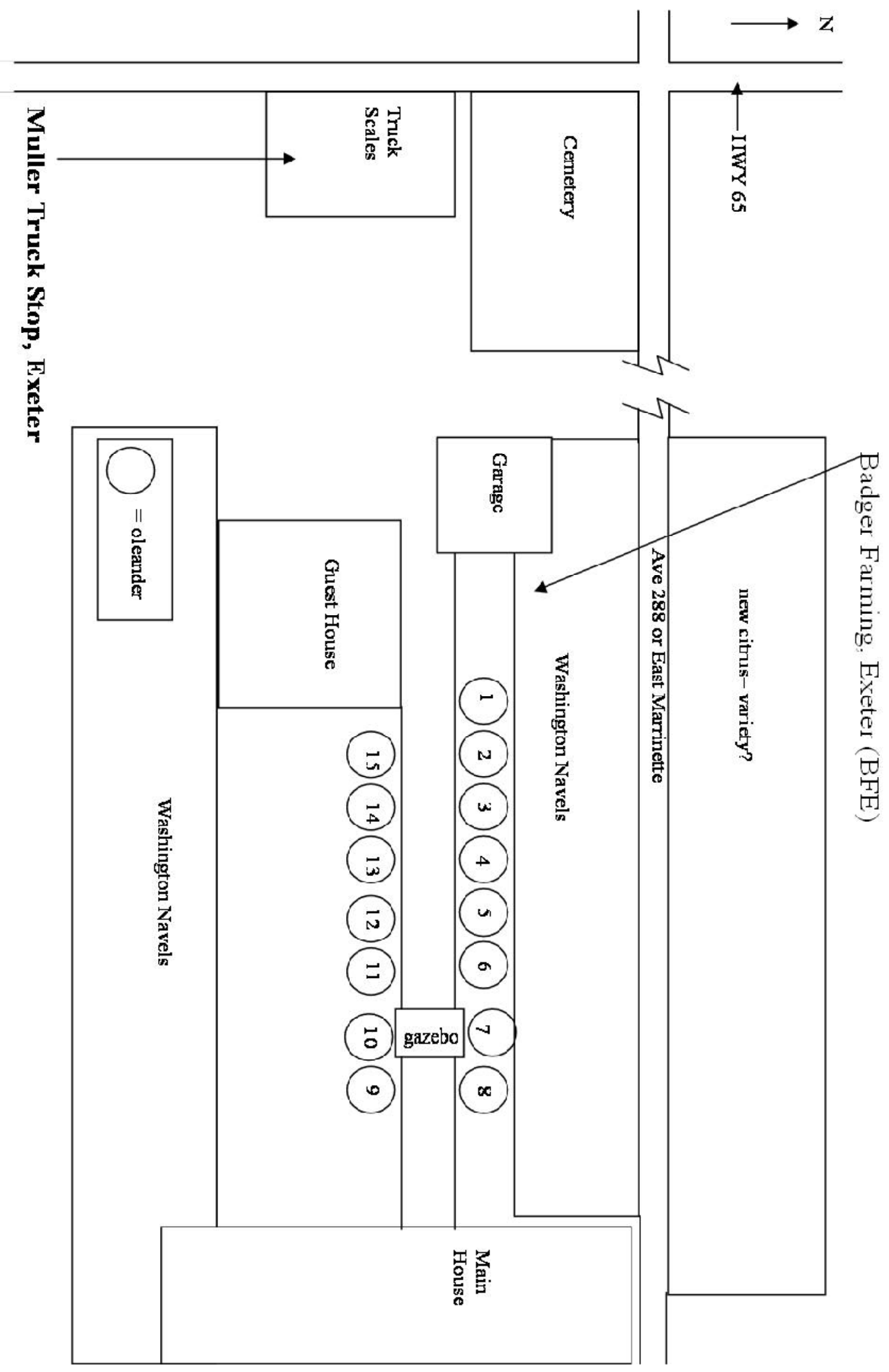

Map3. Badger Farming Exeter (BFE) and Muller truck stop 


\section{Map 4. Stewart Residence}

Jim Stewart's residence

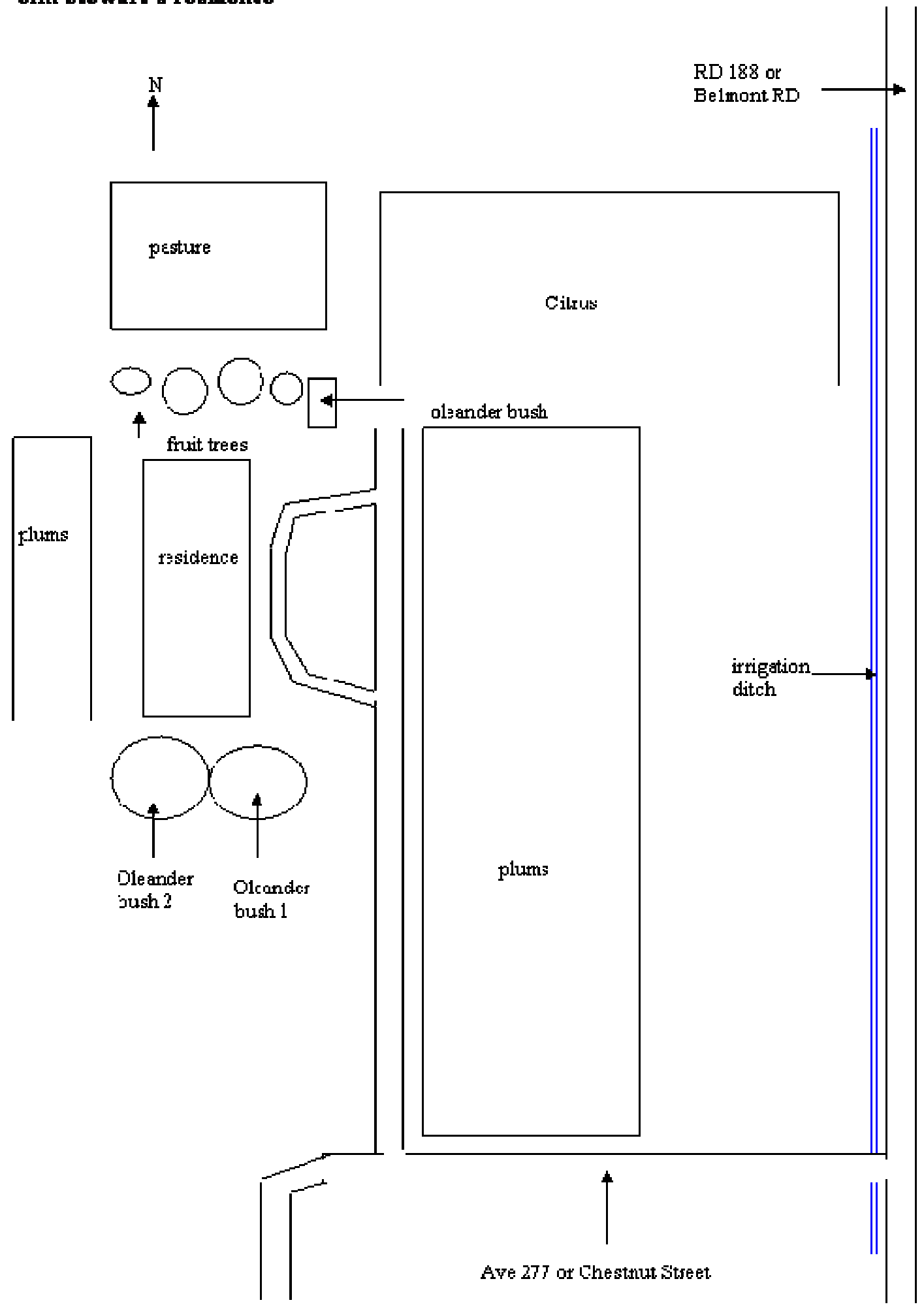




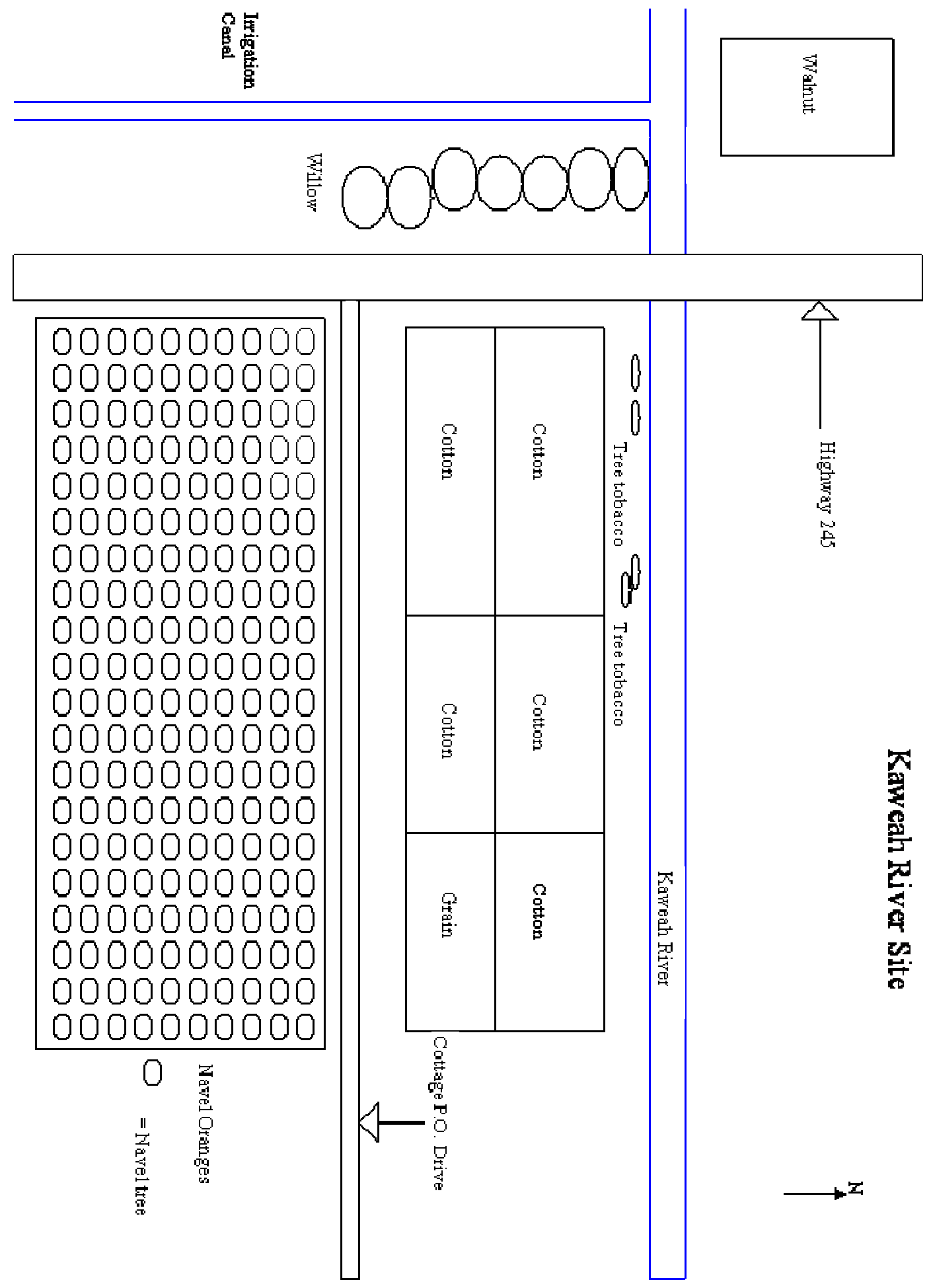

Map 5. Kaweah River site 
Map 6. Burt Quezada Ranch

\section{Burt Quesada Ranch}

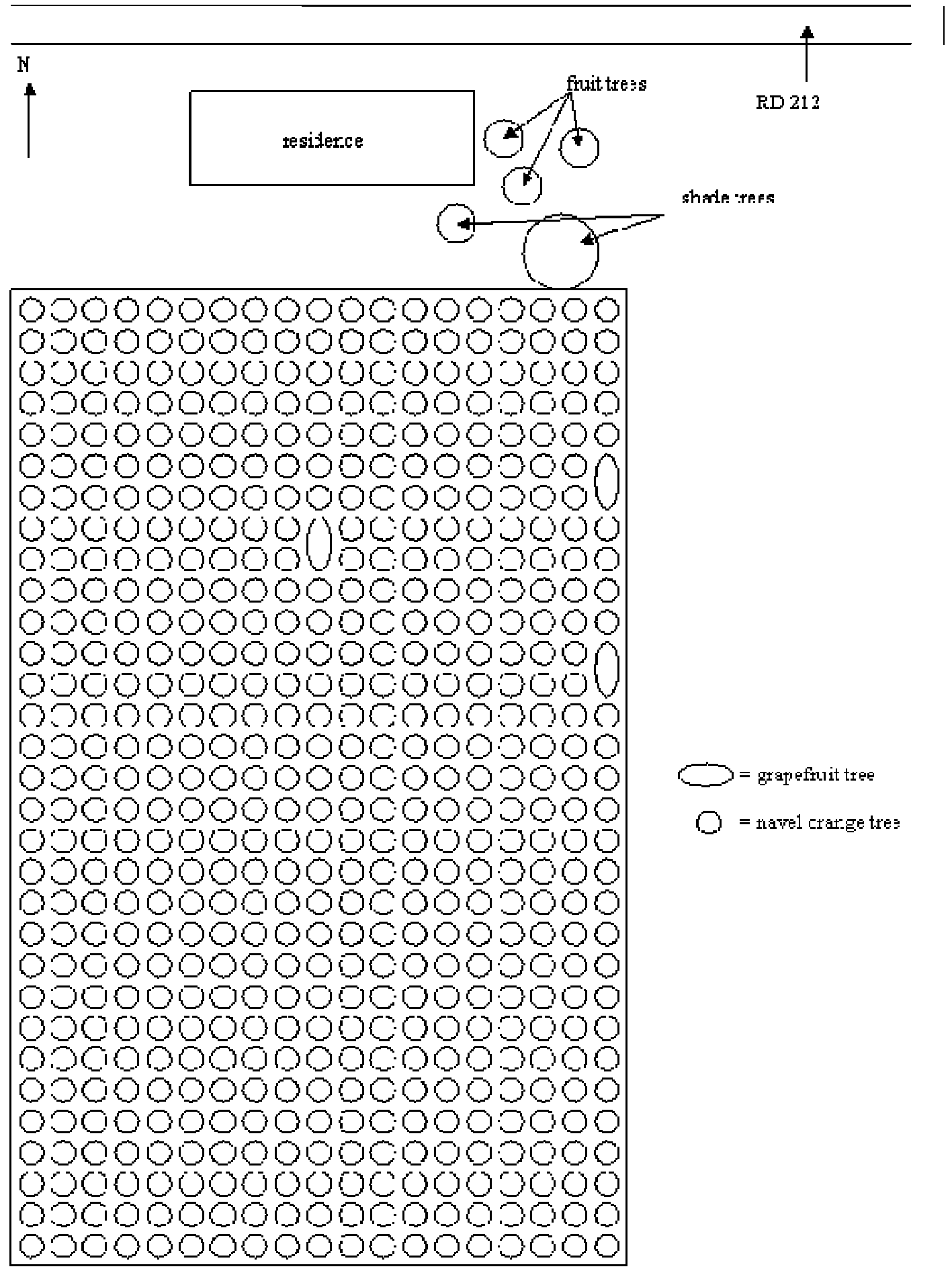


Map 7. Muller Walnut Ranch

Muller Walnuts, Visalia

$\mathrm{N}$

1

vacant field as of 2004

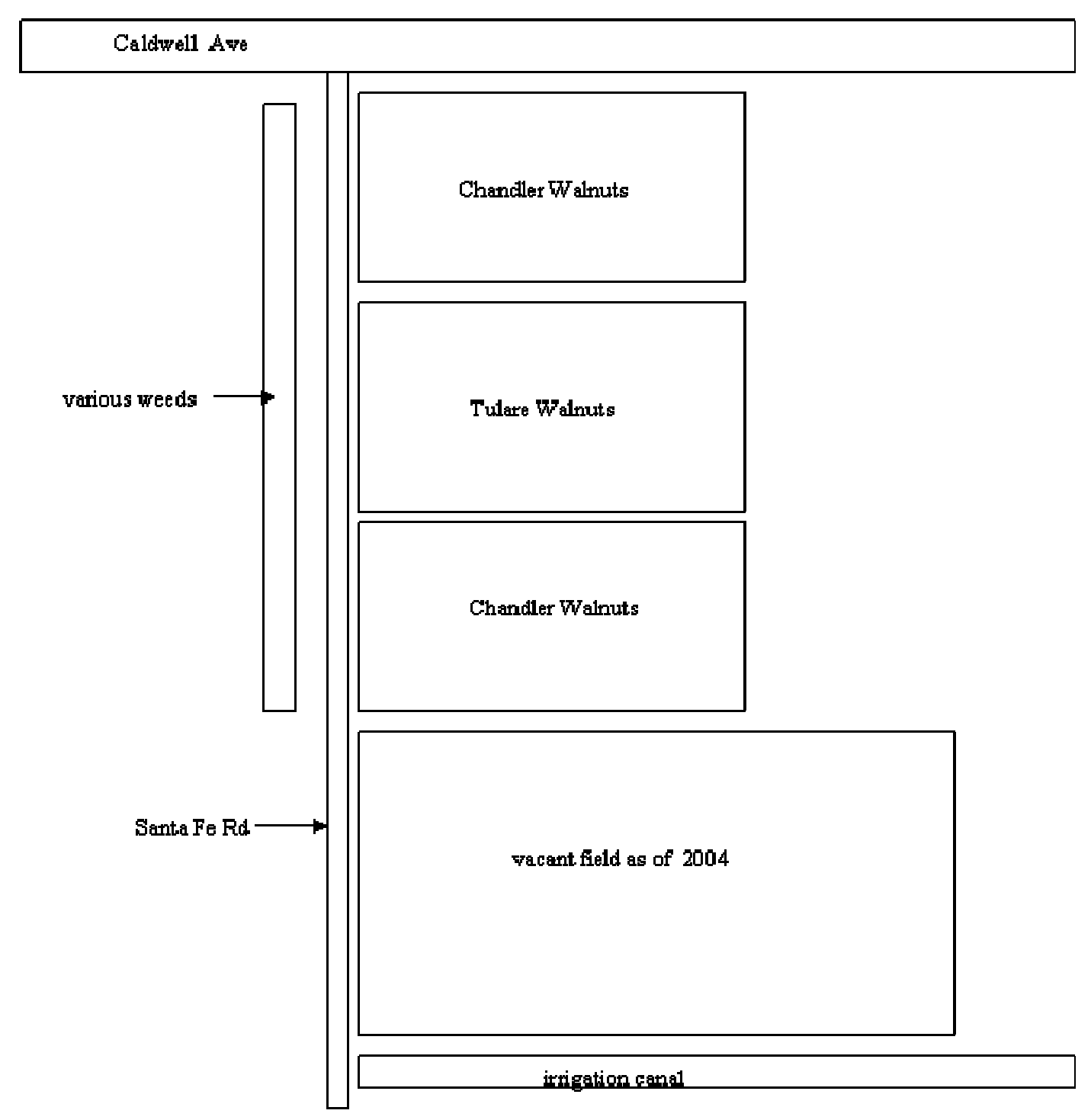


Appendix B. Compiled List of Natural Enemies 


\section{Subfamily Eulophinae in CA}

\section{Cirrospilus}

Compared with: Aulogymnus; Diaulinopsis; Diglyphus; Zagrammosoma

Hosts:

Achrysocharoides splendens - Hymenoptera, Eulophidae

Acrocercops bifasciatus - Lepidoptera, Gracillariidae

Ageniaspis citricola - Hymenoptera, Encyrtidae

Agromyza albipennis - Diptera, Agromyzidae

Agromyza alnivora - Diptera, Agromyzidae

Agromyza demeijerei - Diptera, Agromyzidae

Agromyza frontella - Diptera, Agromyzidae: Alfalfa blotch leafminer

Agromyza nana - Diptera, Agromyzidae

Agromyza parvicornis - Diptera, Agromyzidae: Corn blotch leafminer

Argyresthia freyella - Lepidoptera, Argyresthiidae: Arborvitae leafminer

Argyresthia thuiella - Lepidoptera, Argyresthiidae: Arborvitae leafminer

Aleiodes pallidator - Hymenoptera, Braconidae

Amauromyza populicola - Diptera, Agromyzidae

Andricus nudus - Hymenoptera, Cynipidae: Malpighi's gall causer

Aprostocetus leucopterae - Hymenoptera, Eulophidae

Archips argyrospila - Lepidoptera, Tortricidae: Fruittree leafroller

Archips semiferanus - Lepidoptera, Tortricidae: Oak leafroller

Arge berberidis - Hymenoptera, Argidae: Barberry sawfly

Arge pectoralis - Hymenoptera, Argidae: Birch sawfly

Arge similes - Hymenoptera, Argidae

Aspilapteryx limosella - Lepidoptera, Gracillariidae

Aulagromyza hendeliana - Diptera, Agromyzidae

Aulagromyza populi - Diptera, Agromyzidae

Aulagromyza populicola - Diptera, Agromyzidae

Aylax papaveris - Hymenoptera, Cynipidae

Aylax rhoeadis - Hymenoptera, Cynipidae

Bactrocera oleae - Diptera, Tephritidae: Olive fruit fly

Bedellia somnulentella - Lepidoptera, Lyonetiidae: Sweet potato leaf miner

Bucculatrix ainsliella - Lepidoptera, Bucculatrigidae: Oak skeletonizer

Bucculatrix canadensisella - Lepidoptera, Bucculatrigidae: Birch skeletonizer

Bucculatrix cantabricella - Lepidoptera, Bucculatrigidae

Bucculatrix crataegi - Lepidoptera, Bucculatrigidae

Bucculatrix pomifoliella - Lepidoptera, Bucculatrigidae: Ribbed cocoon maker

Bucculatrix thurberiella - Lepidoptera, Bucculatrigidae: Cotton leaf perforator

Caliroa cerasi - Hymenoptera, Tenthredinidae: Pear sawfly

Callisto denticulella - Lepidoptera, Gracillariidae

Caloptilia elongella - Lepidoptera, Gracillariidae

Caloptilia mongolicae - Lepidoptera,Gracillariidae

Calycomyza humeralis - Diptera, Agromyzidae: Aster leafminer

Cameraria cincinnatiella - Lepidoptera, Gracillariidae: Gregarious oak leafminer

Cedestis subfasciella - Lepidoptera, Yponomeutidae

Cephaloglypta murinanae - Hymenoptera, Ichneumonidae 
Cerodontha dorsalis - Diptera, Agromyzidae: Grass sheathminer

Cerodontha fulvipes - Diptera, Agromyzidae

Ceutorhynchus contractus - Coleoptera, Curculionidae: Cabbage leaf weevil

Choristoneura fumiferana - Lepidoptera, Tortricidae: Spruce budworm

Choristoneura pinus - Lepidoptera, Tortricidae: Pitch pine budworm or Jack pine budworm

Chromatomyia fuscula - Diptera, Agromyzidae

Chromatomyia horticola - Diptera, Agromyzidae: Pea leafminer or garden pea leafminer

Chromatomyia lonicerae - Diptera, Agromyzidae

Chromatomyia milii - Diptera, Agromyzidae

Chromatomyia periclymeni - Diptera, Agromyzidae

Chromatomyia syngenesiae - Diptera, Agromyzidae: Chrysanthemum leafminer

Chrysocharis nautia - Hymenoptea, Eulophidae

Chrysoesthia bosae - Lepidoptera, Gelechiidae

Chrysoesthia sexguttella - Lepidoptera, Gelechiidae

Coccidiphaga scitula - Lepidoptera, Noctuidae

Coleophora binderella - Lepidoptera, Coleophoridae

Coleophora ibipennella - Lepidoptera, Coleophoridae

Coleophora laricella - Lepidoptera, Coleophoridae: Larch casebearer or larch leaf miner

Coleophora malivorella - Lepidoptera, Coleophoridae: Pistol case bearer

Coleophora pruniella - Lepidoptera, Coleophoridae

Coleophora serratella-Lepidoptera, Coleophoridae: Birch casebearer or cigar casebearer

Coleotechnites milleri - Lepidoptera, Gelechiidae: Lodgepole needleminer

Coleotechnites starki - Lepidoptera, Gelechiidae: Northern lodgepole needleminer

Copidosoma deceptor - Hymenoptera, Encyrtidae

Coptodisca splendoriferella - Lepidoptera, Heliozelidae

Cosmopterix attenuatella - Lepidoptera, Cosmopterigidae

Cosmopterix pulchrimella - Lepidoptera, Cosmopterigidae

Cotesia euchaetis - Hymenoptera, Braconidae

Cotesia glomerata - Hymenoptera, Braconidae: Cabbage white butterfly parasite

Cotesia melanoscela - Hymenoptera, Braconidae

Dolichogenidea californica - Hymenoptera, Braconidae

Ectoedemia albifasciella - Lepidoptera, Nepticulidae

Ectoedemia heringella - Lepidoptera, Nepticulidae

Ectoedemia occultella - Lepidoptera, Nepticulidae

Elachista argentella - Lepidoptera, Elachistidae

Elachista cerusella - Lepidoptera, Elachistidae

Emmetia angusticolella - Lepidoptera, Tischeriidae

Eriocrania sparrmannella - Lepidoptera, Eriocraniidae

Eriophyes caulobius - Acari, Eriophyidae

Euleia heraclei - Diptera, Tephritidae: Celery fly

Euproctis phaeorrhoea - Lepidoptera, Lymantriidae: Browntail or brown-tail moth

Exoteleia dodecella - Lepidoptera, Gelechiidae

Exoteleia pinifoliella - Lepidoptera, Gelechiidae: Pine needle miner

Fenusa pusilla - Hymenoptera, Tenthredinidae: Birch leafminer

Fenusa ulmi - Hymenoptera, Tenthredinidae: Elm leafminer 
Gambrus extrematis - Hymenoptera, Ichneumonidae Glyptapanteles liparidis - Hymenoptera, Braconidae Gonipterus scutellatus - Coleoptera, Curculionidae: Eucalptus weevil

Gracillaria limosella - Lepidoptera, Gracillariidae

Gracillaria syringella - Lepidoptera, Gracillariidae: Lilac leafminer

Gregopimpla kuwanae - Hymenoptera, Ichneumonidae

Heterarthrus aceris - Hymenoptera, Tenthredinidae

Heterarthrus nemoratus - Hymenoptera, Tenthredinidae: Late birch edgeminer

Holocacista rivillei - Lepidoptera, Heliozelidae

Hyalophora cecropia - Lepidoptera, Saturniidae: Cecropia moth

Laothoe populi - Lepidoptera, Sphingidae: Poplar hawk-moth

Leucoptera caffeina - Lepidoptera, Lyonetiidae: Coffee leafminer

Leucoptera coffeella - Lepidoptera, Lyonetiidae: Coffee leafminer

Leucoptera coronillae - Lepidoptera, Lyonetiidae

Leucoptera laburnella - Lepidoptera, Lyonetiidae: Laburnum leaf miner

Leucoptera malifoliella - Lepidoptera, Lyonetiidae: Pear leaf blister moth or pear leaf miner

Leucoptera meyricki - Lepidoptera, Lyonetiidae: Coffee leafminer

Leucoptera sinuella - Lepidoptera, Lyonetiidae

Leucoptera spartifoliella - Lepidoptera, Lyonetiidae: Broom twimoth or twig-mining moth

Liriomyza pseudopygmina - Diptera, Agromyzidae

Liriomyza pusilla - Diptera, Agromyzidae: Serpentine leafminer

Liriomyza sativae - Diptera, Agromyzidae: Vegetable leafminer

Liriomyza trifolii - Diptera, Agromyzidae: American serpentine leafminer

Lymantria dispar - Lepidoptera, Lymantriidae: Gypsy moth

Lyonetia clerkella - Lepidoptera, Lyonetiidae: Apple leaf miner

Lyonetia prunifoliella - Lepidoptera, Lyonetiidae

Marmara gulosa - Lepidoptera, Gracillariidae: Citrus peelminer

Massalongia betulifolia - Diptera, Cecidomyiidae

Messa hortulana - Hymenoptera, Tenthredinidae

Metallus gei - Hymenoptera: Tenthredinidae

Meteorus versicolor - Hymenoptera, Braconidae

Metopomyza scutellata - Diptera, Agromyzidae

Metriochroa inferior - Lepidoptera, Gracillariidae

Metriochroa latifoliella - Lepidoptera, Gracillariidae: Small olive leafminer

Metriochroa neglecta - Lepidoptera, Gracillariidae

Misumenops tricuspidatus - Aranea, Thmisidae: Crab spider

Napomyza xylostei - Diptera, Agromyzidae

Nematus desantisi - Hymenoptera, Tenthredinidae

Nematus salicis - Hymenoptera, Tenthredinidae: Large willow sawfly or willow sawfly

Neuroterus numismalis - Hymenoptera, Cynipidae

Neuroterus quercusbaccaru - Hymenoptera, Cynipidae

Ocnerostoma friesei - Lepidoptera, Yponomeutidae

Ocnerostoma piniariellum - Lepidoptera, Yponomeutidae: Ermine moth

Onchocephala montivaga - Coleoptera, Chrysomelidae 
Parafomoria helianthemella - Lepidoptera, Nepticulidae

Parornix anguliferella - Lepidoptera, Gracillariidae

Parornix devoniella - Lepidoptera, Gracillariidae

Parornix geminatella - Lepidoptera, Gracillariidae: Unspotted tentiform leafminer

Parornix persicella - Lepidoptera, Gracillariidae

Parornix petiolella - Lepidoptera, Gracillariidae

Pectinophora gossypiella - Lepidoptera, Gelechiidae: Pink bollworm

Pholetesor circumscriptus - Hymenoptera, Braconidae

Phylacteophaga eucalypti froggatti - Hymenoptera, Pergidae: Leafblister sawfly, leaf-

blister sawfly, or eucalyptus leafmining sawfly

Phyllocnistis citrella - Lepidoptera, Gracillariidae: citrus leafminer

Phyllocnistis populiella - Lepidoptera, Gracillariidae: Aspen serpentine leafminer or

Aspen leafminer

Phyllocnistis tremulella - Lepidoptera, Gracillariidae

Phyllocnistis unipunctella - Lepidoptera, Gracillariidae: Poplar leafminer

Phyllonorycter abrasella - Lepidoptera, Gracillariidae

Phyllonorycter acerifoliella - Lepidoptera, Gracillariidae

Phyllonorycter agilella - Lepidoptera, Gracillariidae

Phyllonorycter anderidae - Lepidoptera, Gracillariidae

Phyllonorycter bicinctella - Lepidoptera, Gracillariidae

Phyllonorycter blancardella - Lepidoptera, Gracillariidae: Spotted tentiform leafminer

Phyllonorycter cavella - Lepidoptera, Gracillariidae

Phyllonorycter comparella - Lepidoptera, Gracillariidae

Phyllonorycter connexella - Lepidoptera, Gracillariidae

Phyllonorycter coryli - Lepidoptera, Gracillariidae: Nut leaf blister moth

Phyllonorycter corylifoliella - Lepidoptera, Gracillariidae: Hawthorn red midget moth

Phyllonorycter crataegella- Lepidoptera Gracillariidae: Apple blotch leafminer

Phyllonorycter cytisella - Lepidoptera, Gracillariidae

Phyllonorycter cytisifoliae - Lepidoptera, Gracillariidae

Phyllonorycter delitella - Lepidoptera, Gracillariidae

Phyllonorycter distentella - Lepidoptera, Gracillariidae

Phyllonorycter dubitella - Lepidoptera, Gracillariidae

Phyllonorycter fagifolia - Lepidoptera, Gracillariidae

Phyllonorycter hancola - Lepidoptera, Gracillariidae

Phyllonorycter helianthemella - Lepidoptera, Gracillariidae

Phyllonorycter kleemannella - Lepidoptera, Gracillariidae

Phyllonorycter lantanella - Lepidoptera, Gracillariidae

Phyllonorycter leucocorona - Lepidoptera, Gracillariidae

Phyllonorycter longispinata - Lepidoptera, Gracillariidae

Phyllonorycter maestingella - Lepidoptera, Gracillariidae

Phyllonorycter malella - Lepidoptera, Gracillariidae: Apple tentiform leafminer or

spotted tentiform leafminer

Phyllonorycter manni - Lepidoptera, Gracillariidae

Phyllonorycter messaniella - Lepidoptera, Gracillariidae: Zellar's midget

Phyllonorycter millierella - Lepidoptera, Gracillariidae

Phyllonorycter nicellii - Lepidoptera, Gracillariidae 
Phyllonorycter oxyacanthae - Lepidoptera, Gracillariidae

Phyllonorycter pastorella - Lepidoptera, Gracillariidae

Phyllonorycter platani - Lepidoptera, Gracillariidae

Phyllonorycter platanoidella - Lepidoptera, Gracillariidae

Phyllonorycter pomifoliella - Lepidoptera, Gracillariidae

Phyllonorycter populifoliella - Lepidoptera, Gracillariidae

Phyllonorycter propinquinella- Lepidoptera, Gracillariidae: Cherry blotchminer

Phyllonorycter pyrifoliella - Lepidoptera, Gracillariidae

Phyllonorycter quercifoliella - Lepidoptera, Gracillariidae

Phyllonorycter rajella - Lepidoptera, Gracillariidae

Phyllonorycter ringoniella - Lepidoptera, Gracillariidae: Apple leafminer

Phyllonorycter roboris - Lepidoptera, Gracillariidae

Phyllonorycter sagitella - Lepidoptera, Gracillariidae

Phyllonorycter salicifoliella - Lepidoptera, Gracillariidae: Aspen blotch leaf miner

Phyllonorycter saliciphaga - Lepidoptera, Gracillariidae

Phyllonorycter salictella - Lepidoptera, Gracillariidae

Phyllonorycter saportella - Lepidoptera, Gracillariidae

Phyllonorycter schreberella - Lepidoptera, Gracillariidae

Phyllonorycter similis - Lepidoptera, Gracillariidae

Phyllonorycter sorbi - Lepidoptera, Gracillariidae

Phyllonorycter sorbicola - Lepidoptera, Gracillariidae

Phyllonorycter spinicolella - Lepidoptera, Gracillariidae

Phyllonorycter spinolella - Lepidoptera, Gracillariidae

Phyllonorycter strigulatella - Lepidoptera, Gracillariidae

Phyllonorycter tenerella - Lepidoptera, Gracillariidae

Phyllonorycter tremulae - Lepidoptera, Gracillariidae

Phyllonorycter tremuloidiella - Lepidoptera, Gracillariidae: Aspen blotchminer

Phyllonorycter tristrigella - Lepidoptera, Gracillariidae

Phyllonorycter turanica - Lepidoptera, Gracillariidae

Phyllonorycter ulmifoliella - Lepidoptera, Gracillariidae

Phytoliriomyza jacarandae - Diptera, Agromyzidae: Jacaranda leafminer

Phytoliriomyza variegate - Diptera, Agromyzidae

Phytomyza angelicae - Diptera, Agromyzidae

Phytomyza artemisivora - Diptera, Agromyzidae

Phytomyza chaerophylli - Diptera, Agromyzidae

Phytomyza citisi - Diptera, Agromyzidae

Phytomyza heringiana - Diptera, Agromyzidae

Phytomyza obscurella - Diptera, Agromyzidae

Phytomyza orobanchia - Diptera, Agromyzidae

Phytomyza ranunculi - Diptera, Agromyzidae

Pnigalio soemius - Hymenoptera, Eulophidae

Poecilocapsus lineatus - Hemiptera, Miridae: Yellow or orange leaf bug

Polyconia spinicornis - Coleoptera, Chrysomelidae

Prays oleae - Lepidoptera, Plutellidae: Olive kernel borer or olive moth

Profenusa pygmaea - Hymenoptera, Tenthredinidae

Psacaphora raschkiella - Lepidoptera, Momphidae 
Recurvaria leucatella - Lepidoptera, Gelechiidae: Lesser budmoth

Rhamphus oxyacanthae - Coleoptera, Curculionidae

Rhamphus pulicarius - Coleoptera, Curculionidae

Rynchaenus alni - Coleoptera, Curculionidae

Rynchaenus fagi - Coleoptera, Curculionidae

Rynchaenus galloisi-Coleoptera, Curculionidae

Rynchaenus japonicus - Coleoptera, Curculionidae

Rynchaenus populi - Coleoptera, Curculionidae

Rynchaenus quercus - Coleoptera, Curculionidae: Oak flea weevil

Rynchaenus rusci - Coleoptera, Curculionidae

Rynchaenus salicis - Coleoptera, Curculionidae

Rynchaenus testaceus - Coleoptera, Curculionidae

Saissetia coffeae - Hemiptera, Coccidae: Hemispherical scale

Scolioneura betuleti - Hymenoptera, Tenthredinidae

Shawiana phyllotomae - Hymenoptera, Braconidae

Silliana hommei - Hymenoptera, Tenthredinidae

Stigmella betulicola - Lepidoptera, Nepticulidae

Stigmella catharticella - Lepidoptera, Nepticulidae

Stigmella centifoliella - Lepidoptera, Nepticulidae

Stigmella floslactella - Lepidoptera, Nepticulidae

Stigmella hemargyrella - Lepidoptera, Nepticulidae

Stigmella hybnerella - Lepidoptera, Nepticulidae

Stigmella incognitella - Lepidoptera, Nepticulidae

Stigmella juglandifoliella - Lepidoptera, Nepticulidae: Pecan serpentine leafminer

Stigmella malella - Lepidoptera, Nepticulidae: Banded apple pigmy

Stigmella mespilicola - Lepidoptera, Nepticulidae

Stigmella microtheriella - Lepidoptera, Nepticulidae

Stigmella myrtillella - Lepidoptera, Nepticulidae

Stigmella oxyacanthella - Lepidoptera, Nepticulidae

Stigmella paradoxa - Lepidoptera, Nepticulidae

Stigmella pyri - Lepidoptera, Nepticulidae

Stigmella roborella - Lepidoptera, Nepticulidae

Stigmella ruficapitella - Lepidoptera, Nepticulidae

Stigmella salicis - Lepidoptera, Nepticulidae

Stigmella samiatella - Lepidoptera, Nepticulidae

Stigmella sorbi - Lepidoptera, Nepticulidae

Stigmella tityrella - Lepidoptera, Nepticulidae

Stigmella trimaculella - Lepidoptera, Nepticulidae

Stigmella ulmivora - Lepidoptera, Nepticulidae

Tischeria dodonaea - Lepidoptera, Tischeriidae

Tischeria ekebladella - Lepidoptera, Tischeriidae

Tischeria malifoliella - Lepidoptera, Tischeriidae: Apple leaf trumpet miner

Vanessa atalanta - Lepidoptera, Nymphalidae: Red admiral

Zeiraphera griseana - Lepidoptera: Tortricidae: Dingy larch bell 


\section{Pnigalio}

host:

Achrysocharoides splendens - Hymenoptera, Eulophidae

Acidia cognata - Diptera, Tephritidae

Agromyza albipennis - Diptera, Agromyzidae

Agromyza alnibetulae - Diptera, Agromyzidae

Agromyza alnivora - Diptera, Agromyzidae

Agromyza aristata - Diptera, Agromyzidae: Elm agromyzid leafminer

Agromyza demeijerei - Diptera, Agromyzidae

Agromyza flaviceps - Diptera, Agromyzidae

Agromyza frontella -Diptera, Agromyzidae: Alfalfa blotch leafminer

Agromyza mobilis - Diptera, Agromyzidae

Agromyza nana - Diptera, Agromyzidae

Agromyza oryzae - Diptera, Agromyzidae: Rice leafminer, Japanese leaf miner, Japanese

rice leafminer

Agromyza parvicornis - Diptera, Agromyzidae: Corn blotch leafminer

Agromyza potentillae - Diptera, Agromyzidae

Ancylis comptana - Lepidoptera, Tortricidae: Strawberry leafroller

Anthonomus morulus - Coleoptera, Curculionidae

Antispila isabella - Lepidoptera, Heliozelidae

Alsophila pometaria - Lepidoptera, Geometridae: Fall cankerworm

Amauromyza morionella - Diptera, Agromyzidae

Amphipyra pyramidoides - Lepidoptera, Noctuidae: American copper underwing or

pyramidal green fruitworm

Anthonomus pomorum - Coleoptera, Curculionidae: Apple blossom weevil

Argyresthia aureoargentella - Lepidoptera, Argyresthiidae: Canadian arborative leafminer

Argyresthia thuiella - Lepidoptera, Argyresthiidae: arborvitae leafminer

Aulagromyza hendeliana - Diptera, Agromyzidae

Aulagromyza populi - Diptera, Agromyzidae

Aulagromyza populicola - Diptera, Agromyzidae

Bactrocera oleae- Diptera, Tephritidae: Olive fruit fly

Baliosus rubber - Coleoptera, Chrysomelidae: Basswood leafminer

Bedellia orchilella - Lepidoptera, Lyonetiidae: Sweetpotato leafminer

Brachys tessellates - Coleoptera, Buprestidae

Bucculatrix ainsliella - Lepidoptera, Bucculatrigidae: Oak skeletonizer

Bucculatrix packardella - Lepidoptera, Bucculatrigidae

Calycomyza artemisiae - Diptera, Agromyzidae

Caliroa cerasi - Hymenoptera, Tenthredinidae: Pear sawfly

Caloptilia hemidactylella - Lepidoptera, Gracillariidae

Calybites auroguttellus - Lepidoptera, Gracillariidae

Cameraria aceriella - Lepidoptera, Gracillariidae: Maple leafblotch miner

Cameraria caryaefoliella - Lepidoptera, Gracillariidae

Cameraria cincinnatiella - Lepidoptera, Gracillariidae: Gregarious oak leafminer

Cameraria hamadryadella - Lepidoptera, Gracillariidae: Solitary oak leafminer 
Cameraria hamameliella - Lepidoptera, Gracillariidae

Cameraria ohridella - Lepidoptera, Gracillariidae: Horse chestnut leafminer

Cameraria picturatella - Lepidoptera, Gracillariidae

Caulocampus acericaulis - Hymenoptera, Tenthredinidae: Maple petiole borer

Cerodontha phragmitidis - Diptera, Agromyzidae

Ceutorhynchus contractus - Coleoptera, Curculionidae: Cabbage leaf weevil

Chalepus suturalis - Coleoptera, Chrysomelidae

Chirosia parvicornis - Diptera, Anthomyiidae

Chromatomyia horticola - Diptera, Agromyzidae: Pea leafminer or garden pea leafminer

Chromatomyia milii - Diptera, Agromyzidae

Chromatomyia periclymeni - Diptera, Agromyzidae

Chromatomyia syngenesiae - Diptera, Agromyzidae: Chrysanthemum leafminer

Chrysaster ostensackenella - Lepidoptera, Gracillariidae

Chrysoesthia sexguttella - Lepidoptera, Gelechiidae

Chrysocharis nautia - Hymenoptea, Eulophidae

Coleophora pruniella - Lepidoptera, Coleophoridae

Coleophora serratella- Lepidoptera, Coleophoridae: Birch casebearer or cigar casebearer

Coptodisca kalmiella - Lepidoptera, Heliozelidae

Coptodisca splendoriferella - Lepidoptera, Heliozelidae

Curculio salicivorus - Coleoptera, Curculionidae

Cydia pomonella - Lepidoptera, Tortricidae: Codling moth

Diacopia nyssaefoliella - Lepidoptera, Heliozelidae

Dyseriocrania subpurpurella - Lepidoptera, Eriocraniidae

Ectoedemia agrimoniae - Lepidoptera, Nepticulidae

Ectoedemia atricollis - Lepidoptera, Nepticulidae

Ectoedemia occultella - Lepidoptera, Nepticulidae

Ectoedemia septembrella - Lepidoptera, Nepticulidae

Elachista cerusella - Lepidoptera, Elachistidae

Elachista humilis - Lepidoptera, Elachistidae

Emmetia heinemanni - Lepidoptera, Tischeriidae

Emmetia angusticolella - Lepidoptera, Tischeriidae

Eriocrania sparrmannella - Lepidoptera, Eriocraniidae

Eupelmus martellii - Hymenoptera, Euplemidae

Eupelmus urozonus - Hymenoptera, Euplemidae

Euura mисronata - Hymenoptera, Tenthredinidae: Willow bud galler

Fenella arenariae - Hymenoptera, Tenthredinidae

Fenusa dohrnii - Hymenoptera, Tenthredinidae: European alder leafminer

Fenusa pusilla - Hymenoptera, Tenthredinidae: Birch leafminer

Fenusa ulmi - Hymenoptera, Tenthredinidae: Elm leafminer

Gracillaria syringella - Lepidoptera, Gracillariidae: Lilac leafminer

Heterarthrus nemoratus - Hymenoptera, Tenthredinidae: Late birch edgeminer

Heterarthrus ochropoda - Hymenoptera, Tenthredinidae

Heterarthrus wuestneii - Hymenoptera, Tenthredinidae

Heterocampa guttivitta - Lepidoptera, Notodontidae: Maple prominent or saddled prominent

Holocacista rivillei - Lepidoptera, Heliozelidae 
Hypera arator - Coleoptera, Curculionidae

Hypurus bertrandi - Coleoptera, Curculionidae: Portulaca leafmining weevil

Kessleria saxifragae - Lepidoptera, Yponomeutidae

Lacanobia oleracea - Lepidoptera, Noctuidae: Bright-line Brown-eye

Liriomyza dopygmina - Diptera, Agromyzidae

Liriomyza eupatorii - Diptera, Agromyzidae

Liriomyza huidobrensis - Diptera, Agromyzidae: Pea leafminer

Liriomyza pseudopygmina - Diptera, Agromyzidae

Leucanthiza amphicarpeaefoliella - Lepidoptera, Gracillariidae

Leucanthiza dircella - Lepidoptera, Gracillariidae

Leucoptera aceris - Lepidoptera, Lyonetiidae

Leucoptera coffeella - Lepidoptera, Lyonetiidae: Coffee leafminer

Leucoptera laburnella - Lepidoptera, Lyonetiidae: Laburnum leaf miner

Leucoptera lotella - Lepidoptera, Lyonetiidae

Leucoptera lustratella - Lepidoptera, Lyonetiidae

Leucoptera malifoliella - Lepidoptera, Lyonetiidae: Pear leaf blister moth or pear leaf miner

Leucoptera sinuella - Lepidoptera, Lyonetiidae

Leucospilapteryx omissella - Lepidoptera, Gracillariidae

Lyonetia clerkella - Lepidoptera, Lyonetiidae: Apple leaf miner

Lyonetia saliciella - Lepidoptera, Lyonetiidae: Birch leafminer

Mamestra brassicae - Lepidoptera, Noctuidae: Cabbage moth

Mantura floridana - Coleoptera; Chrysomelidae

Messa hortulana - Hymenoptera, Tenthredinidae

Messa nana - Hymenoptera, Tenthredinidae: Early birch leaf edgeminer

Metallus gei - Hymenoptera: Tenthredinidae

Metallus rohweri - Hymenoptera, Tenthredinidae

Metriochroa latifoliella - Lepidoptera, Gracillariidae: Small olive leafminer

Metriochroa neglecta - Lepidoptera, Gracillariidae

Microrhopala vittata - Coleoptera, Chrysomelidae

Mompha epilobiella - Lepidoptera, Momphidae

Neuroterus numismalis - Hymenoptera, Cynipidae

Neurobathra strigifinitella - Lepidoptera, Gracillariidae

Nycteola revayana - Lepidoptera, Noctuidae: Oak Nycteoline

Octotoma plicatula - Coleoptera, Chrysomelidae

Odontota dorsalis - Coleoptera, Chrysomelidae: Locust leafminer

Pamphilius stramineipes - Hymenoptera, Pamphiliidae

Paonias excaecata - Lepidoptera, Sphingidae: Blinded sphinx

Paraclemensia acerifoliella - Lepidoptera, Incurvariidae: Maple leafcutter moth

Parectopa robiniella- Lepidoptera, Gracillariidae: Locust digitate leafminer

Parornix geminatella - Lepidoptera, Gracillariidae: Unspotted tentiform leafminer

Parornix kalmiella - Lepidoptera, Gracillariidae

Perittia weberella - Lepidoptera, Elachistidae

Pexicopia malvella - Lepidoptera, Gelechiidae: Hollyhock seed moth

Pholetesor circumscriptus - Hymenoptera, Braconidae

Phyllocnistis citrella- Lepidoptera, Gracillariidae: Citrus leafminer 
Phyllocnistis populiella - Lepidoptera, Gracillariidae: Aspen serpentine leafminer or Aspen leafminer

Phyllocnistis tremulella - Lepidoptera, Gracillariidae

Phyllonorycter acerifoliella - Lepidoptera, Gracillariidae

Phyllonorycter anderidae - Lepidoptera, Gracillariidae

Phyllonorycter blancardella - Lepidoptera, Gracillariidae: Spotted tentiform leafminer

Phyllonorycter cavella - Lepidoptera, Gracillariidae

Phyllonorycter celtisella - Lepidoptera, Gracillariidae

Phyllonorycter comperella - Lepidoptera, Gracillariidae

Phyllonorycter corylifoliella - Lepidoptera, Gracillariidae: Hawthorn red midget moth

Phyllonorycter crataegella - Lepidoptera Gracillariidae: Apple blotch leafminer

Phyllonorycter cydoniella - Lepidoptera Gracillariidae

Phyllonorycter elmaella - Lepidoptera Gracillariidae: Western tentiform leafminer

Phyllonorycter emberizaepennella - Lepidoptera Gracillariidae

Phyllonorycter froelichiella - Lepidoptera Gracillariidae

Phyllonorycter gaultheriella - Lepidoptera Gracillariidae

Phyllonorycter heegeriella - Lepidoptera Gracillariidae

Phyllonorycter junoniella - Lepidoptera Gracillariidae

Phyllonorycter kleemannella - Lepidoptera Gracillariidae

Phyllonorycter maestingella - Lepidoptera Gracillariidae

Phyllonorycter messaniella - Lepidoptera, Gracillariidae: Zellar's midget

Phyllonorycter malimalifoliella - Lepidoptera, Gracillariidae: Spotted tentiform leafminer

Phyllonorycter mespilella - Lepidoptera, Gracillariidae: Tentiform leafminer

Phyllonorycter millierella - Lepidoptera, Gracillariidae

Phyllonorycter nicellii - Lepidoptera, Gracillariidae

Phyllonorycter nigrescentella - Lepidoptera, Gracillariidae

Phyllonorycter ostryaefoliella - Lepidoptera, Gracillariidae

Phyllonorycter oxyacanthae - Lepidoptera, Gracillariidae

Phyllonorycter platani - Lepidoptera, Gracillariidae

Phyllonorycter platanoidella - Lepidoptera, Gracillariidae

Phyllonorycter pomifoliella - Lepidoptera, Gracillariidae

Phyllonorycter populiella - Lepidoptera, Gracillariidae

Phyllonorycter populifoliella - Lepidoptera, Gracillariidae

Phyllonorycter propinquinella- Lepidoptera, Gracillariidae: Cherry blotchminer

Phyllonorycter pyrifoliella - Lepidoptera, Gracillariidae

Phyllonorycter quercifoliella - Lepidoptera, Gracillariidae

Phyllonorycter quinnata - Lepidoptera, Gracillariidae

Phyllonorycter quinqueguttella - Lepidoptera, Gracillariidae

Phyllonorycter rajella - Lepidoptera, Gracillariidae

Phyllonorycter ringoniella - Lepidoptera, Gracillariidae: Apple leafminer

Phyllonorycter roboris - Lepidoptera, Gracillariidae

Phyllonorycter salicifoliella - Lepidoptera, Gracillariidae: Aspen blotch leaf miner

Phyllonorycter saliciphaga - Lepidoptera, Gracillariidae

Phyllonorycter salictella viminiella - Lepidoptera, Gracillariidae

Phyllonorycter schreberella - Lepidoptera, Gracillariidae 
Phyllonorycter sorbi - Lepidoptera, Gracillariidae

Phyllonorycter spinicolella - Lepidoptera, Gracillariidae

Phyllonorycter spinolella - Lepidoptera, Gracillariidae

Phyllonorycter stettinensis - Lepidoptera, Gracillariidae

Phyllonorycter tenerella - Lepidoptera, Gracillariidae

Phyllonorycter tremuloidiella - Lepidoptera, Gracillariidae: Aspen blotchminer

Phyllonorycter tristrigella - Lepidoptera, Gracillariidae

Phyllonorycter ulmifoliella - Lepidoptera, Gracillariidae

Phytoliriomyza melampyga - Diptera, Agromyzidae

Phytoliriomyza variegate - Diptera, Agromyzidae

Phytomyza angelicae - Diptera, Agromyzidae

Phytomyza aquilegiae - Diptera, Agromyzidae

Phytomyza artemisivora - Diptera, Agromyzidae

Phytomyza heringiana - Diptera, Agromyzidae

Phytomyza ilicicola - Diptera, Agromyzidae: Native holly leafminer

Phytomyza ilicis - Diptera, Agromyzidae: Holly leafminer

Phytomyza minuscula - Diptera, Agromyzidae

Phytomyza obscurella - Diptera, Agromyzidae

Phytomyza plantaginis - Diptera, Agromyzidae

Phytomyza pubicornis - Diptera, Agromyzidae

Phytomyza ranunculi - Diptera, Agromyzidae

Phytomyza solidaginis - Diptera, Agromyzidae

Phytomyza spondylii - Diptera, Agromyzidae

Pontania proxima - Hymenoptera, Tenthredinidae

Pontania resinicola - Hymenoptera, Tenthredinidae

Pontania s-desmodioides - Hymenoptera, Tenthredinidae

Pontania triandrae - Hymenoptera, Tenthredinidae

Pontania viminalis - Hymenoptera, Tenthredinidae

Prays oleae - Lepidoptera, Plutellidae: Olive kernel borer or olive moth

Pristiphora alnivora - Hymenoptera, Tenthredinidae: olumbine sawfly

Pristiphora rufipes - Hymenoptera, Tenthredinidae

Profenusa lucifex - Hymenoptera, Tenthredinidae

Profenusa pygmaea - Hymenoptera, Tenthredinidae

Protolithocolletis lathyri - Lepidoptera, Gracillariidae

Pycnoglossa histricina - Diptera, Anthomyiidae

Recurvaria leucatella - Lepidoptera, Gelechiidae: Lesser budmoth

Rhamphus oxyacanthae - Coleoptera, Curculionidae

Rhamphus pulicarius - Coleoptera, Curculionidae

Rhopalomyia ptarmicae - Diptera, Cecidomyiidae

Rynchaenus alni - Coleoptera, Curculionidae

Rynchaenus ermischi - Coleoptera, Curculionidae

Rynchaenus fagi - Coleoptera, Curculionidae

Rynchaenus pallicornis - Coleoptera, Curculionidae

Rynchaenus quercus - Coleoptera, Curculionidae: Oak flea weevil

Rynchaenus rusci - Coleoptera, Curculionidae

Rynchaenus salicis - Coleoptera, Curculionidae 
Rynchaenus testaceus - Coleoptera, Curculionidae

Sharliphora ambigua - Hymenoptera, Tenthredinidae

Sharliphora amphibole - Hymenoptera, Tenthredinidae

Shawiana phyllotomae - Hymenoptera, Braconidae

Scolioneura betuleti - Hymenoptera, Tenthredinidae

Sphaeroderma rubidum - Coleoptera, Chrysomelidae

Stegobium paniceum - Coleoptera, Anobiidae: Drugstore or bisquit beetle

Stigmella aceris - Lepidoptera, Nepticulidae

Stigmella atricapitella - Lepidoptera, Nepticulidae

Stigmella belfragrella - Lepidoptera, Nepticulidae

Stigmella catharticella - Lepidoptera, Nepticulidae

Stigmella crataegella - Lepidoptera, Nepticulidae

Stigmella floslactella - Lepidoptera, Nepticulidae

Stigmella hemargyrella - Lepidoptera, Nepticulidae

Stigmella hybnerella - Lepidoptera, Nepticulidae

Stigmella malella - Lepidoptera, Nepticulidae: Banded apple pigmy

Stigmella myrtillella - Lepidoptera, Nepticulidae

Stigmella nylandriella - Lepidoptera, Nepticulidae

Stigmella oxyacanthella - Lepidoptera, Nepticulidae

Stigmella ruficapitella - Lepidoptera, Nepticulidae

Stigmella salicis - Lepidoptera, Nepticulidae

Stigmella sorbi - Lepidoptera, Nepticulidae

Stigmella tityrella - Lepidoptera, Nepticulidae

Tischeria ambrosiaeella - Lepidoptera, Tischeriidae

Tischeria castaneaeella - Lepidoptera, Tischeriidae

Tischeria deciduas - Lepidoptera, Tischeriidae

Tischeria dodonaea - Lepidoptera, Tischeriidae

Tischeria ekebladella - Lepidoptera, Tischeriidae

Tischeria immaculate - Lepidoptera, Tischeriidae

Tischeria malifoliella - Lepidoptera, Tischeriidae: Apple leaf trumpet miner

Trypeta artemisiae - Diptera, Tephritidae

Urophora stylata - Diptera, Tephritidae: Spear thistle seed fly or bull thistle seed fly

Zeugophora flavicollis - Coleoptera, Megalopodidae

\section{Hyssopus}

Host:

Argyrotaenia citrana - Lepidoptera, Tortricidae: Orange tortrix

Barbara colfaxiana - Lepidoptera, Tortricidae: Douglas-fir cone moth

Cnephasia chrysantheana - Lepidoptera, Tortricidae

Coleophora concolorella - Lepidoptera, Coleophoridae

Coleophora cratipennella - Lepidoptera, Coleophoridae

Coleophora alticolella - Lepidoptera, Coleophoridae

Coleophora glaucicolella - Lepidoptera, Coleophoridae

Coleophora juncicolella - Lepidoptera, Coleophoridae

Coleophora valesianella - Lepidoptera, Coleophoridae

Cydia funebrana - Lepidoptera, Tortricidae: Plum fruit moth 
Cydia injective - Lepidoptera, Tortricidae

Cydia latiferreana - Lepidoptera, Tortricidae: Filbertworm moth

Cydia miscitata - Lepidoptera, Tortricidae

Cydia piperana - Lepidoptera, Tortricidae: Seed worm or Ponderosa pine seed worm

Cydia pomonella - Lepidoptera, Tortricidae: Codling moth

Cydia strobilella - Lepidoptera, Tortricidae: Spruce seed moth

Dioryctria abietella - Lepidoptera, Pyralidae: Spruce coneworm or Fir coneworm

Dioryctria abietivorella - Lepidoptera, Pyralidae: Fir coneworm

Dioryctria amatella - Lepidoptera, Pyralidae: Southern pine coneworm

Dioryctria auranticella - Lepidoptera, Pyralidae: Ponderosa pine coneworm

Dioryctria cambiicola - Lepidoptera, Pyralidae: Douglas-fir pitch moth

Dioryctria pineae - Lepidoptera, Pyralidae

Dioryctria ponderosae - Lepidoptera, Pyralidae: Ponderosa twig moth

Dioryctria splendidella - Lepidoptera, Pyralidae: Pine stem borer or Maritime pine stem borer

Dioryctria sylvestrella - Lepidoptera, Pyralidae

Dioryctria tumicolella - Lepidoptera, Pyralidae: Pine pitch moth or pitch moth

Dioryctria zimmermani - Lepidoptera, Pyralidae: Zimmerman pine moth

Endothenia albolineana - Lepidoptera, Tortricidae: Spruce needleminer

Endothenia montanana - Lepidoptera, Tortricidae

Eupoecilia roseana - Lepidoptera, Tortricidae

Exoteleia dodecella - Lepidoptera, Gelechiidae

Galleria mellonella - Lepidoptera, Pyralidae: Greater wax moth

Grapholita molesta - Lepidoptera, Tortricidae: Oriental fruit moth

Ips bidentatus - Coleoptera, Scolytidae

Limnaecia phragmitella - Lepidoptera, Cosmopterigidae

Metzneria lapella - Lepidoptera, Gelechiidae:

Paranthrene tabaniformis - Lepidoptera, Sesiidae: Dusky clearwing

Parectopa robiniella - Lepidoptera, Gracillariidae: Locust digitate leafminer

Petrova albicapitana - Lepidoptera, Tortricidae: Northern pitch twig moth

Petrova comstockiana - Lepidoptera, Tortricidae: Pitch twig moth

Petrova houseri - Lepidoptera, Tortricidae

Petrova metallica - Lepidoptera, Tortricidae: Ponderosa pine caterpillar

Petrova wenzeli - Lepidoptera, Tortricidae

Pityogenes chalcographus - Coleoptera, Scolytidae: Six-spined spruce bark beetle

Pseudococcyx tessulatana - Lepidoptera, Tortricidae: Cone tortricid

Rhyacionia buoliana - Lepidoptera, Tortricidae: European pine shoot moth

Rhyacionia frustrana - Lepidoptera, Tortricidae: Nantucket pine tip moth

Rhyacionia neomexicana - Lepidoptera, Tortricidae: Southwestern pine tip moth

Rhyacionia resinella - Lepidoptera, Tortricidae

Rhyacionia rigidana - Lepidoptera, Tortricidae: Pitch pine tip moth

Synanthedon exitiosa - Lepidoptera, Aegeriidae: Peachtree borer

Synanthedon pictipes - Lepidoptera, Sesiidae: Lesser peachtree borer

Synanthedon pini - Lepidoptera, Sesiidae

Synanthedon scitula - Lepidoptera, Sesiidae: Dogwood borer 
Thecodiplosis brachyntera - Diptera, Cecidiomyiidae: Needle-shortening pine gall midge Trupanea amoena - Diptera, Tephritidae

\section{Aulogymnus}

Host:

Adleria coriaria - Hymenoptera, Cynipidae

Adleria coronata - Hymenoptera, Cynipidae

Adleria glutinosa - Hymenoptera, Cynipidae

Adleria kollari - Hymenoptera, Marble gall wasp

Andricus aestivalis - Hymenoptera, Cynipidae: oak gall wasp

Andricus albopunctatus - Hymenoptera, Cynipidae

Andricus amenti - Hymenoptera, Cynipidae

Andricus callidoma - Hymenoptera, Cynipidae

Andricus caputmedusae - Hymenoptera, Cynipidae

Andricus clementinae - Hymenoptera, Cynipidae

Andricus coronaries - Hymenoptera, Cynipidae

Andricus crispator - Hymenoptera, Cynipidae

Andricus curvator - Hymenoptera, Cynipidae

Andricus fecundatrix - Hymenoptera, Cynipidae

Andricus gemmeus - Hymenoptera, Cynipidae

Andricus grossulariae - Hymenoptera, Cynipidae

Andricus hungaricus - Hymenoptera, Cynipidae

Andricus inflator - Hymenoptera, Cynipidae

Andricus lignicola - Hymenoptera, Cynipidae

Andricus lucidus - Hymenoptera, Cynipidae

Andricus nudus - Hymenoptera, Cynipidae

Andricus ostreus - Hymenoptera, Cynipidae

Andricus quadrilineatus - Hymenoptera, Cynipidae

Andricus quercuscalicis - Hymenoptera, Cynipidae

Andricus quercusradicis - Hymenoptera, Cynipidae

Andricus quercusramuli - Hymenoptera, Cynipidae

Andricus solitarius - Hymenoptera, Cynipidae

Andricus testaceipes - Hymenoptera, Cynipidae

Biorhiza pallida - Hymenoptera, Cynipidae: Oak apple gall wasp

Callirhytis flora - Hymenoptera, Cynipidae

Callirhytis glandium - Hymenoptera, Cynipidae

Cynips quercusfolii - Hymenoptera, Cynipidae

Hylesinus fraxini - Coleoptera, Scolytidae: bark and ambrosia beetle

Neuroterus albipes - Hymenoptera, Cynipidae: Smooth spangle gall wasp

Neuroterus glandiformis - Hymenoptera, Cynipidae

Neuroterus numismalis - Hymenoptera, Cynipidae

Neuroterus quercusbaccaru - Hymenoptera, Cynipidae

Neuroterus saliens - Hymenoptera, Cynipidae

Pediaspis aceris - Hymenoptera, Cynipidae

Phyllonorycter - Lepidoptera, Gracillariidae

Synergus gallaepomiformis - Hymenoptera, Cynipidae 
Synergus pallicornis - Hymenoptera, Cynipidae

Trigonaspis megaptera - Hymenoptera, Cynipidae

\section{Dicladocerus}

Host:

Agromyza ambigua - Diptera, Agromyzidae

Archips oporana - Lepidoptera, Tortricidae

Argyresthia conjugella - Lepidoptera, Argyresthiidae: Apple fruit moth

Argyresthia franciscella - Lepidoptera, Argyresthiidae

Argyresthia freyella - Lepidoptera, Argyresthiidae: Arborvitae leafminer

Argyresthia thuiella - Lepidoptera, Argyresthiidae: Arborvitae leafminer

Callimorpha dominula - Lepidoptera, Arctiidae: Scarlet tiger moth

Calycomyza humeralis - Diptera, Agromyzidae: Aster leafminer

Carposina scirrhosella - Lepidoptera, Carposinidae

Cedestis gysseleniella -Lepidoptera, Yponomeutidae

Cedestis subfasciella -Lepidoptera, Yponomeutidae

Choristoneura fumiferana - Lepidoptera, Tortricidae: Spruce budworm

Chromatomyia syngenesiae - Diptera, Agromyzidae: Chrysanthemum leafminer

Coleophora caespititiella - Lepidoptera, Coleophoridae

Coleophora comptoniella - Lepidoptera, Coleophoridae

Coleophora dahurica - Lepidoptera, Coleophoridae

Coleophora laricella - Lepidoptera, Coleophoridae: Larch casebearer or larch leaf miner

Coleophora longisignella - Lepidoptera, Coleophoridae

Coleophora obscenella - Lepidoptera, Coleophoridae

Coleophora taeniipennella - Lepidoptera, Coleophoridae

Coleotechnites apicitripunctellus - Lepidoptera, Gelechiidae

Coleotechnites milleri - Lepidoptera, Gelechiidae: Lodgepole needleminer

Coleotechnites piceaella - Lepidoptera, Gelechiidae

Coleotechnites starki - Lepidoptera, Gelechiidae: Northern lodgepole needleminer

Croesia bergmanniana - Lepidoptera, Tortricidae

Cydia tenebrosana - Lepidoptera, Tortricidae

Epinotia transmissana - Lepidoptera, Tortricidae

Exoteleia pinifoliella - Lepidoptera, Gelechiidae: Pine needle miner

Gypsonoma aceriana - Lepidoptera, Tortricidae: Poplar shoot borer

Gypsonoma sociana - Lepidoptera, Tortricidae

Hydrellia griseola - Diptera, Ephydridae

Liriomyza compositella - Diptera, Agromyzidae

Liriomyza flaveola - Diptera, Agromyzidae

Ocnerostoma piniariellum - Lepidoptera, Yponomeutidae: Ermine moth

Phytomyza geniculata - Diptera, Agromyzidae

Prays oleae - Lepidoptera, Plutellidae: Olive kernel borer or olive moth

Psyche casta - Lepidoptera, Psychidae: Bagworm moth

Recurvaria nanella - Lepidoptera, Gelechiidae: Lesser budmoth

Scythris temperatella - Lepidoptera, Scythrididae

Thaumetopoea pityocampa - Lepidoptera, Thaumetopoeidae: Pine procession moth

Tortrix viridana - Lepidoptera, Tortricidae: European oak leafroller 
Tropicomyia vigneae - Diptera, Agromyzidae

Zeiraphera griseana - Lepidoptera: Tortricidae: Dingy larch bell

\section{Elasmus}

Host:

Acanthopsyche atra - Lepidoptera, Psychidae

Acrobasis comptoniella - Lepidoptera, Pyralidae: Sweetfern leaf casebearer

Acrobasis rubrifasciella - Lepidoptera, Pyralidae

Acrocercops helicometra - Lepidoptera, Gracillariidae

Aleiodes hyphantriae - Hymenoptera, Braconidae

Aleiodes stigmator - Hymenoptera, Braconidae

Anania verbascalis - Lepidoptera, Pyralidae

Anarsia lineatella - Lepidoptera, Gelechiidae: Peach twig borer

Anomalococcus indicus - Hemiptera, Coccidae

Anomis flava - Lepidoptera, Noctuidae: Cotton looper

Antigastra catalaunalis - Lepidoptera, Pyralidae: Sesame podborer or sesame webworm Antispila anna - Lepidoptera, Gracillariidae: Jamun leaf miner

Apanteles canarsiae - Hymenoptera, Braconidae

Apanteles diparopsidis - Hymenoptera, Braconidae

Apanteles galleriae - Hymenoptera, Braconidae

Apanteles importunus- Hymenoptera, Braconidae

Apanteles langerburgensis - Hymenoptera, Braconidae

Apanteles leucostigmus - Hymenoptera, Braconidae

Apanteles machaeralis - Hymenoptera, Braconidae

Apanteles malevolus - Hymenoptera, Braconidae

Apanteles pelops - Hymenoptera, Braconidae

Apanteles risbeci - Hymenoptera, Braconidae

Apanteles syleptae - Hymenoptera, Braconidae

Apanteles taragamae - Hymenoptera, Braconidae

Aproaerema modicella - Lepidoptera, Gelechiidae: Groundnut leafminer

Apterona crenulella - Lepidoptera, Psychidae

Archips rosana - Lepidoptera, Tortricidae: European leafroller or rose tortrix moth

Bracon brevicornis - Hymenoptera, Braconidae

Bilobata subsecivella - Lepidoptera, Gelechiidae

Bissetia steniella - Lepidoptera, Pyralidae: Gurdaspur borer

Cameraria guttifinitella - Lepidoptera, Gracillariidae

Canephora hirsuta - Lepidoptera, Psychidae

Ceroplastes rusci-Hemiptera, Coccidae: Fig wax scale

Chilo infuscatellus - Lepidoptera, Pyralidae: Sugarcane stem borer

Chilo phaeosema - Lepidoptera, Pyralidae

Choreutis pariana - Lepidoptera, Choreutidae: Apple leaf skeletonizer

Choristoneura fumiferana - Lepidoptera, Tortricidae: Spruce budworm

Chrysodeixeis eriosoma - Lepidoptera, Noctuidae

Cnaphalocrocis grisealis - Lepidoptera, Pyralidae

Cnaphalocrocis medinalis - Lepidoptera, Pyralidae: Rice leaf roller

Cnaphalocrocis suspicalis - Lepidoptera, Pyralidae 
Cnaphalocrocis trapezalis - Lepidoptera, Pyralidae

Coccidiphaga scitula - Lepidoptera, Noctuidae

Coleophora caespititiella - Lepidoptera, Coleophoridae

Coleophora malivorella - Lepidoptera, Coleophoridae: Pistol casebearer

Coleophora pruniella - Lepidoptera, Coleophoridae

Coleophora serratella- Lepidoptera, Coleophoridae: Birch casebearer or cigar casebearer

Coleophora vibicella - Lepidoptera, Coleophoridae

Coptodisca splendoriferella - Lepidoptera, Heliozelidae

Cotesia americana - Hymenoptera, Braconidae

Cotesia delicate - Hymenoptera, Braconidae

Cotesia glomerata - Hymenoptera, Braconidae: Cabbage white butterfly parasite

Cotesia hyphantriae - Hymenoptera, Braconidae

Cotesia marginiventris - Hymenoptera, Braconidae

Cudonigera houstonana - Lepidoptera, Tortricidae: Juniper budworm

Cydia critica - Lepidoptera, Tortricidae: Leaf webber

Cydia leucostoma - Lepidoptera, Tortricidae: Flushworm

Cydia pomonella - Lepidoptera, Tortricidae: Codling moth

Cydia pseudonectis - Lepidoptera, Tortricidae

Cydia tricentra - Lepidoptera, Tortricidae: Top shoot borer

Deuterohyalina albida - Lepidoptera, Psychidae

Diadegma armillatum - Hymenoptera, Ichneumonidae

Diadegma fenestrale - Hymenoptera, Ichneumonidae

Diaphania indica - Lepidoptera, Pyralidae: Cotton caterpillar, cucumber moth, pumpkin caterpillar, or melon moth

Dichocrocis megillalis - Lepidoptera, Pyralidae

Dioryctria disclusa - Lepidoptera, Pyralidae: Webbing coneworm

Dolichogenidea aethiopica - Hymenoptera, Braconidae

Earias biplaga - Lepidoptera, Noctuidae: Spiny bollworm

Earias cupreoviridis - Lepidoptera, Noctuidae: Diamond bollworm or spiny bollworm

Earias insulana - Lepidoptera, Noctuidae: Spiny bollworm

Earias vittella - Lepidoptera, Noctuidae: Spotted bollworm

Eccopsis wahlbergiana - Lepidoptera, Tortricidae

Elasmus senegalensis - Hymenoptera, Eulophidae

Ephestia kuehniella - Lepidoptera, Pyralidae: Mediterranean Flour or Mill Moth

Epinotia nigricana - Lepidoptera, Tortricidae: Bud-borer tortricid

Erionota thrax - Lepidoptera, Hesperiidae: Banana leafroller, banana skipper, palm redeye

Erionota torus - Lepidoptera, Hesperiidae: Banana skipper

Etiella zinckenella - Lepidoptera, Pyralidae: Lima bean pod borer

Eublemma amabilis - Lepidoptera, Noctuida

Eudarcia abchasicum - Lepidoptera, Tineidae

Eudarcia leopoldella - Lepidoptera, Tineidae

Eupoecilia ambiguella - Lepidoptera, Tortricidae: Eurpean grape berry moth

Euproctis chrysorrhoea - Lepidoptera, Lymantriidae: browntail moth

Exenterus amictorius - Hymenoptera, Ichneumonidae

Exoteleia dodecella - Lepidoptera: Gelechiidae 
Galleria mellonella - Lepidoptera, Pyralidae: Greater wax moth

Geina periscelidactyla - Lepidoptera, Pterophoridae: Plume moth

Glyphodes pyloalis - Lepidoptera, Pyralidae: Mulberry pyralid

Goniozus claripennis - Hymenoptera, Bethylidae

Haritalodes derogata - Lepidoptera, Pyralidae: Cotton leaf roller

Herpetogramma stultale - Lepidoptera, Pyralidae

Holocacista rivillei - Lepidoptera, Heliozelidae

Homadaula anisocentra - Lepidoptera, Plutellidae: Mimosa webworm

Homona coffearia - Lepidoptera, Tortricidae: Coffee tortrix

Hormius moniliatus - Hymenoptera, Braconidae

Hyblaea puera - Lepidoptera, Hyblaeidae: Teak defoliator

Hyphantria cunea - Lepidoptera, Arctiidae: Fall webworm moth

Hyposoter fugitivus - Hymenoptera, Ichneumonidae

Hyposoter rivalis - Hymenoptera, Ichneumonidae

Janus compressus - Hymenoptera, Cephidae: Pear impulse wasp

Laccifer lacca - Hemiptera, Kerriidae: Lac scale

Leucoma salicis - Lepidoptera, Lyonetiidae: Satin Moth

Leucoptera caffeina - Lepidoptera, Lyonetiidae: Coffee leafminer

Leucoptera coffeella - Lepidoptera, Lyonetiidae: Coffee leafminer

Leucoptera coma - Lepidoptera, Lyonetiidae

Leucoptera meyricki - Lepidoptera, Lyonetiidae: Coffee leafminer

Lobesia botrana - Lepidoptera, Tortricidae: Grapevine moth

Lobesia semblidis - Lepidoptera, Tortricidae

Luffia lapidella - Lepidoptera, Psychidae

Lymantria dispar - Lepidoptera, Lymantriidae: Gypsy moth

Macrocentrus linearis - Hymenoptera: Braconidae

Malacosoma americanum - Lepidoptera, Lasiocampidae: Eastern tent caterpillar

Manatha albipes - Lepidoptera, Psychidae: Bag worm

Manduca sexta - Lepidoptera, Sphingidae: Tobacco horn worm

Megalophanes turatii - Lepidoptera, Psychidae

Meteorus hyphantriae - Hymenoptera, Braconidae

Meteorus laphygmae - Hymenoptera, Braconidae

Meteorus rubens - Hymenoptera, Braconidae

Meteorus trachynotus - Hymenoptera, Braconidae

Nausinoe geometralis - Lepidoptera, Pyralidae: Jasmine leaf webworm

Neaspilota alba - Diptera, Tephritidae

Nephantis serinopa - Lepidoptera, Xylorictidae: Coconut leaf-eating caterpillar

Nephopterix rhodobasalis - Lepidoptera, Pyralidae

Noorda moringae - Lepidoptera, Pyralidae

Notarcha obrinusalis - Lepidoptera, Pyralidae

Notarcha quaternalis - Lepidoptera, Pyralidae

Nyereria mlanje - Hymenoptera: Braconidae

Odites artigena - Lepidoptera, Lecithoceridae

Omiodes diemenalis - Lepidoptera, Pyralidae: Bean leafroller

Omiodes indicata - Lepidoptera, Pyralidae

Opisina arenosella - Lepidoptera, Oecophoridae: Coconut black-headed caterpillar 
Oreopsyche tabanivicinella - Lepidoptera, Psychidae

Oreopsyche vesubiella - Lepidoptera, Psychidae

Orgyia leucostigma - Lepidoptera, Lymantriidae: White-marked Tussock moth

Ostrinia nubilalis - Lepidoptera, Pyralidae: European corn borer

Palpita machaeralis - Lepidoptera, Pyralidae: Teak leaf eating caterpillar

Parametriotes theae - Lepidoptera, Agonoxenidae

Paramictoides febretta - Lepidoptera, Psychidae

Parotis marinata - Lepidoptera, Pyralidae

Pectinophora gossypiella - Lepidoptera, Gelechiidae: Pink bollworm

Pelopidas mathias - Lepidoptera, Hesperiidae: Small branded swift

Petrova cristata - Lepidoptera, Tortricidae: Japanese pine shoot borer

Pexicopia malvella - Lepidoptera, Gelechiidae: Hollyhock seed moth

Phalacropterix apiformis - Lepidoptera, Psychidae

Phanerotoma hendecasisella - Hymenoptera, Braconidae

Phlyctaenia coronata - Lepidoptera, Pyralidae: Webworm moth

Phobocampe clisiocampae - Hymenoptera, Ichneumonidae

Phobocampe pallipes - Hymenoptera, Ichneumonidae

Phthorimaea operculella - Lepidoptera: Gelechiidae: Potato tuberworm or potato tuber moth

Phylacteophaga eucalypti froggatti - Hymenoptera, Tenthredinidae: Leafblister sawfly

or eucalyptus leaf mining sawfly

Phyllocnistis citrella - Lepidoptera, Gracillariidae: Citrus leafminer

Phyllonorycter crataegella - Lepidoptera Gracillariidae: Apple blotch leafminer

Phyllonorycter malella - Lepidoptera, Gracillariidae: Apple tentiform leafminer or spotted tentiform leafminer

Polistes canadensis annularis - Hymenoptera, Vespidae

Polistes crinitus - Hymenoptera, Vespidae

Polistes dorsalis - Hymenoptera, Vespidae

Polistes exclamans - Hymenoptera, Vespidae

Polistes fuscatus - Hymenoptera, Vespidae: Golden paper wasp

Polistes gallicus - Hymenoptera, Vespidae

Polistes hebraeus - Hymenoptera, Vespidae

Polistes instabilis - Hymenoptera, Vespidae: Neotropic eusocial wasp

Polistes major - Hymenoptera, Vespidae

Polistes opinabilis - Hymenoptera, Vespidae

Polistes snelleni - Hymenoptera, Vespidae

Porphyrosela desmodiella - Lepidoptera, Gracillariidae

Prays acmonias - Lepidoptera, Plutellidae

Prays citri - Lepidoptera, Plutellidae: Citrus flower moth

Prays oleae - Lepidoptera, Plutellidae: Olive kernel borer or olive moth

Procerata sacchariphaga - Lepidoptera, Brachodidae

Promecotheca reichei - Coleoptera: Chrysomelidae: Coconut leaf mining beatle or palm leaf mining beetle

Pseudohypatopa pulverea - Lepidoptera, Blastobasidae

Psorosina hammondi - Lepidoptera, Pyralidae: Appleleaf skeletonizer

Psyche albipes - Lepidoptera, Psychidae 
Psyche constancella - Lepidoptera, Psychidae

Pyrausta aurata - Lepidoptera, Pyralidae

Rhyacionia frustrana - Lepidoptera, Tortricidae: Nantucket pine tip moth

Saucrobotys futilalis - Lepidoptera, Pyralidae: Panic moth

Schoenobius bipunctifer - Lepidoptera, Pyralidae: Rice stem borer

Scirpophaga exerptalis - Lepidoptera, Pyralidae: Sugarcane top borer

Scirpophaga nivella - Lepidoptera, Pyralidae: White rice borer

Scutellista caerulea - Hymenoptera, Pteromalidae

Scythropia crataegella - Lepidoptera, Yponomeutidae: Hawthorn moth

Sinophorus validus - Hymenoptera, Ichneumonidae

Sparganothis pilleriana - Lepidoptera, Tortricidae: Long palped tortrix

Spodoptera frugiperda - Lepidoptera, Noctuidae: Fall armyworm

Stomphastis thraustica - Lepidoptera, Gracillariidae

Syngamia abruptalis - Lepidoptera, Pyralidae: Leaf webber

Tebenna bjerkandrella - Lepidoptera, Choreutidae

Thyridopteryx ephemeraeformis - Lepidoptera, Psychidae: Bagworm moth

Tirathaba mundella - Lepidoptera, Pyralidae: Oil palm bunch moth

Tischeria malifoliella - Lepidoptera, Tischeriidae: Apple leaf trumpet miner

Tischeria solidagonifoliella - Lepidoptera, Tischeriidae

Tropobracon antennatus - Hymenoptera: Braconidae

Urbanus proteus - Lepidoptera, Hesperiidae: Long-tailed skipper

Yponomeuta malinella - Lepidoptera, Yponomeutidae: Apple ermine moth

Yponomeuta padella - Lepidoptera, Yponomeutidae: Small ermine moth

Zeuzera pyrina - Lepidoptera, Cossidae: Leopard moth

\section{Diglyphus}

Host:

Acidia cognata - Diptera, Tephritidae

Agromyza albipennis - Diptera, Agromyzidae

Agromyza alnivora - Diptera, Agromyzidae

Agromyza demeijerei - Diptera, Agromyzidae

Agromyza frontella - Diptera, Agromyzidae: alfalfa blotch leafminer

Agromyza nana - Diptera, Agromyzidae

Agromyza oryzae - Diptera, Agromyzidae: Rice leafminer, Japanese leaf miner, Japanese rice leafminer

Agromyza parvicornis - Diptera, Agromyzidae: Corn blotch leafminer

Agromyza rufipes - Diptera, Agromyzidae

Agromyza salicifolii - Diptera, Agromyzidae

Aulagromyza hendeliana - Diptera, Agromyzidae

Aulagromyza populi - Diptera, Agromyzidae

Aulagromyza populicola - Diptera, Agromyzidae

Calycomyza artemisiae - Diptera, Agromyzidae

Calycomyza humeralis - Diptera, Agromyzidae: Aster leafminer

Calycomyza jucunda - Diptera, Agromyzidae

Cerodontha dorsalis - Diptera, Agromyzidae: Grass sheathminer

Cerodontha fulvipes - Diptera, Agromyzidae 
Chromatomyia aprilina - Diptera, Agromyzidae

Chromatomyia fuscula - Diptera, Agromyzidae

Chromatomyia horticola - Diptera, Agromyzidae: Pea leafminer or garden pea leafminer

Chromatomyia lonicerae - Diptera, Agromyzidae

Chromatomyia milii - Diptera, Agromyzidae

Chromatomyia periclymeni - Diptera, Agromyzidae

Chromatomyia suikazurae - Diptera, Agromyzidae

Chromatomyia syngenesiae -Diptera, Agromyzidae: Chrysanthemum leafminer

Dizygomyza crucifericola - Diptera, Agromyzidae

Hydrellia griseola - Diptera, Ephydridae

Japanagromyza inaequalis - Diptera, Agromyzidae

Leucoptera sinuella - Lepidoptera, Lyonetiidae

Liriomyza ativae - Diptera, Agromyzidae

Liriomyza bryoniae - Diptera, Agromyzidae: Celery miner

Liriomyza chilensis - Diptera, Agromyzidae

Liriomyza cicerinae - Diptera, Agromyzidae

Liriomyza congesta - Diptera, Agromyzidae: Bean leafminer

Liriomyza flaveola - Diptera, Agromyzidae

Liriomyza helianthi - Diptera, Agromyzidae

Liriomyza huidobrensis- Diptera, Agromyzidae: pea leafminer

Liriomyza pictella - Diptera, Agromyzidae: Melon leafminer

Liriomyza pusilla - Diptera, Agromyzidae: Serpentine leafminer

Liriomyza pusio - Diptera, Agromyzidae

Liriomyza sativae- Diptera, Agromyzidae: Vegetable leafminer

Liriomyza strigata - Diptera, Agromyzidae

Liriomyza taraia - Diptera, Agromyzidae

Liriomyza trifoliearum - Diptera, Agromyzidae

Liriomyza trifolii - Diptera, Agromyzidae: American serpentine leafminer

Lyonetia clerkella - Lepidoptera, Lyonetiidae: Apple leaf miner

Melanagromyza obtuse - Diptera, Agromyzidae

Melanagromyza virens - Diptera, Agromyzidae

Meoneura obscurella - Diptera, Carnidae

Metopomyza scutellata - Diptera, Agromyzidae

Nanophyes niger - Coleoptera, Curculionidae

Napomyza xylostei - Diptera, Agromyzidae

Nemorimyza posticata - Diptera, Agromyzidae

Pedicellina lucens - Diptera, Stratiomyidae

Phyllocnistis citrella - Lepidoptera, Gracillariidae: Citrus leafminer

Phyllonorycter millierella - Lepidoptera, Gracillariidae

Phyllonorycter spinicolella - Lepidoptera, Gracillariidae

Phytagromyza dianthicola - Diptera, Agromyzidae

Phytagromyza jannonei - Diptera, Agromyzidae

Phytoliriomyza jacarandae - Diptera, Agromyzidae: Jacaranda leafminer

Phytoliriomyza melampyga - Diptera, Agromyzidae

Phytoliriomyza variegate - Diptera, Agromyzidae

Phytomyza affinis - Diptera, Agromyzidae 
Phytomyza albiceps - Diptera, Agromyzidae

Phytomyza angelicae - Diptera, Agromyzidae

Phytomyza aquilegiae - Diptera, Agromyzidae

Phytomyza chaerophylli - Diptera, Agromyzidae

Phytomyza citisi - Diptera, Agromyzidae

Phytomyza cytisi - Diptera, Agromyzidae

Phytomyza echinopis - Diptera, Agromyzidae

Phytomyza jucunda - Diptera, Agromyzidae

Phytomyza lanati - Diptera, Agromyzidae

Phytomyza lappina - Diptera, Agromyzidae

Phytomyza marginella - Diptera, Agromyzidae

Phytomyza melana - Diptera, Agromyzidae

Phytomyza minuscule - Diptera, Agromyzidae

Phytomyza mylini - Diptera, Agromyzidae

Phytomyza obscurella - Diptera, Agromyzidae

Phytomyza orobanchia - Diptera, Agromyzidae

Phytomyza paniculatae - Diptera, Agromyzidae

Phytomyza plantaginis - Diptera, Agromyzidae

Phytomyza pubicornis - Diptera, Agromyzidae

Phytomyza ranunculi - Diptera, Agromyzidae

Phytomyza rapunculi caulinaris - Diptera, Agromyzidae

Phytomyza solidaginis - Diptera, Agromyzidae

Phytomyza spondylii - Diptera, Agromyzidae

Phytomyza vitalbae - Diptera, Agromyzidae

Phytomyza vomitoriae - Diptera, Agromyzidae

Poemyza lateralis - Diptera, Agromyzidae

Pseudonapomyza asiatica - Diptera, Agromyzidae

Stigmella juglandifoliella - Lepidoptera, Nepticulidae: Pecan serpentine leafminer

Stigmella malella - Lepidoptera, Nepticulidae: Banded apple pigmy

Trypeta artemisiae - Diptera, Tephritidae

\section{Zagrammosoma}

Host:

Agromyza parvicornis - Diptera, Agromyzidae: Corn blotch leafminer

Bireta goddrica

Brachys tessellates - Coleoptera, Buprestidae

Bucculatrix thurberiella - Lepidoptera, Bucculatrigidae: Cotton leaf perforator

Caloptilia alnivorella - Lepidoptera, Gracillaridae

Cameraria cincinnatiella - Lepidoptera, Gracillariidae: Gregarious oak leafminer

Cameraria hamadryadella - Lepidoptera, Gracillariidae: Solitary oak leafminer

Cameraria mediodorsella - Lepidoptera, Gracillariidae

Cameraria nemoris - Lepidoptera, Gracillariidae

Chrysaster ostensackenella - Lepidoptera, Gracillariidae

Coleophora malivorella - Lepidoptera, Coleophoridae: Pistol case bearer

Coleophora pruniella - Lepidoptera, Coleophoridae

Coleotechnites milleri - Lepidoptera, Gelechiidae: Lodgepole needleminer 
Exoteleia pinifoliella - Lepidoptera, Gelechiidae: Pine needle miner

Keiferia lycopersicella - Lepidoptera, Gelechiidae: Tomato pinworm

Leucoptera coffeella - Lepidoptera, Lyonetiidae: Coffee leafminer

Liriomyza archboldi - Diptera, Agromyzidae

Liriomyza huidobrensis - Diptera, Agromyzidae: Pea leafminer

Liriomyza pictella - Diptera, Agromyzidae: Melon leafminer

Liriomyza pusilla - Diptera, Agromyzidae: Serpentine leafminer

Liriomyza sativae - Diptera, Agromyzidae: Vegetable leafminer

Metopomyza scutellata - Diptera, Agromyzidae

Microrhopala xerene - Coleoptera, Chrysomelidae

Parornix geminatella - Lepidoptera, Gracillariidae: Unspotted tentiform leafminer

Phthorimaea operculella - Lepidoptera: Gelechiidae: Potato tuberworm or potato tuber moth

Phyllocnistis citrella- Lepidoptera, Gracillariidae: Citrus leafminer

Phyllocnistis magnoliella - Lepidoptera, Gracillariidae: Magnolia serpentine leafminer

Phyllonorycter blancardella- Lepidoptera, Gracillariidae: Spotted tentiform leafminer

Phyllonorycter crataegella - Lepidoptera, Gracillariidae: apple blotch leafminer

Phyllonorycter elmaella - Lepidoptera Gracillariidae: Western tentiform leafminer

Phytomyza aquilegiae - Diptera, Agromyzidae

Phytomyza minuscule - Diptera, Agromyzidae

Phytomyza vomitoriae - Diptera, Agromyzidae

Scolioneura betuleti - Hymenoptera, Tenthredinidae

Tischeria malifoliella - Lepidoptera, Tischeriidae: Apple leaf trumpet miner

\section{Diaulinopsis}

Host:

Calycomyza artemisiae - Diptera, Agromyzidae

Calycomyza jucunda - Diptera, Agromyzidae

Cerodontha dorsalis - Diptera, Agromyzidae: Grass sheathminer

Cerodontha fulvipes - Diptera, Agromyzidae

Liriomyza brassicae - Diptera, Agromyzidae: Serpentine leafminer

Liriomyza pictella - Diptera, Agromyzidae: Melon leafminer

Liriomyza pusilla - Diptera, Agromyzidae: Serpentine leafminer

Liriomyza sativae - Diptera, Agromyzidae: Vegetable leafminer

Metopomyza scutellata - Diptera, Agromyzidae

Phyllonorycter ringoniella - Lepidoptera, Gracillariidae: Apple leafminer

\section{Sympiesis}

Host:

Achrysocharoides splendens - Hymenoptera, Eulophidae

Acleris chalybeana - Lepidoptera, Tortricidae: Lesser maple leafroller

Acleris lipsiana - Lepidoptera, Tortricidae

Acleris minuta - Lepidoptera, Tortricidae: Yellowheaded fireworm

Actia pilipennis - Diptera, Tachinidae

Acrobasis caryivorella - Lepidoptera, Pyralidae

Acrobasis indigenella - Lepidoptera, Pyralidae: Leaf crumpler moth 
Acrobasis juglandis - Lepidoptera, Pyralidae: Pecan leaf casebearer Acrocercops brongniardella - Lepidoptera, Gracillariidae Acrocercops syngramma - Lepidoptera, Gracillariidae Adoxophyes orana - Lepidoptera, Tortricidae: Summerfruit tortrix Agonopterix posticella - Lepidoptera, Oecophoridae Agromyza parvicornis - Diptera, Agromyzidae: Corn blotch leafminer Aleiodes gastritor - Hymenoptera, Braconidae Anacampsis populella - Lepidoptera, Gelechiidae Ancylis comptana - Lepidoptera, Tortricidae: Strawberry leafroller Ancylis divisana - Lepidoptera, Tortricidae Ancylis mitterbacheriana - Lepidoptera, Tortricidae Andricus curvator - Hymenoptera, Cynipidae Aproaerema modicella - Lepidoptera, Gelechiidae: Groundnut leafminer Apotomis lutoscana - Lepidoptera, Tortricidae Archips argyrospila - Lepidoptera, Tortricidae: Fruittree leafroller Archips rosana - Lepidoptera, Tortricidae: European leafroller or rose tortrix moth Archips xylosteana - Lepidoptera, Tortricidae: Brown oak tortrix or variegated golden tortrix

Argyrotaenia amatana - Lepidoptera, Tortricidae Argyrotaenia citrana - Lepidoptera, Tortricidae: Orange tortrix

Argyrotaenia velutinana - Lepidoptera, Tortricidae: Red-banded leaf roller Aristotelia zygophylliforella - Lepidoptera, Gelechiidae Aspilapteryx limosella - Lepidoptera, Gracillariidae Bedellia somnulentella -Lepidoptera, Lyonetiidae: Sweet potato leafminer Blastobasis aurantiaca - Lepidoptera, Blastobasidae Blastotere thuiella - Lepidoptera, Agyresthiidae Brachys tessellates - Coleoptera, Buprestidae Callisto multimaculta - Lepdoptera, Gracillariidae Caloptilia alchimiella - Lepidoptera, Gracillariidae Caloptilia alnivorella - Lepidoptera, Gracillariidae Caloptilia azaleella - Lepidoptera, Gracillariidae: Azalea leaf miner Caloptilia betulicola - Lepidoptera, Gracillariidae

Caloptilia cuculipennella - Lepidoptera, Gracillariidae Caloptilia elongella - Lepidoptera, Gracillariidae Caloptilia fidella - Lepidoptera, Gracillariidae Caloptilia fraxinella - Lepidoptera, Gracillariidae: Ash leaf cone roller Caloptilia fribergensis - Lepidoptera, Gracillariidae Caloptilia hemidactylella - Lepidoptera, Gracillariidae Caloptilia monticola - Lepidoptera, Gracillariidae Caloptilia negundella - Lepidoptera, Gracillariidae: Boxelder leafroller Caloptilia perseae - Lepidoptera, Gracillariidae: Avocado leafminer Caloptilia rhombifoliella - Lepidoptera, Gracillariidae Caloptilia roscipennella - Lepidoptera, Gracillariidae Caloptilia sassafrasella - Lepidoptera, Gracillariidae Caloptilia soyella - Lepidoptera, Gracillariidae Caloptilia stigmatella - Lepidoptera, Gracillariidae 
Caloptilia theivora - Lepidoptera, Gracillariidae

Calybites auroguttellus - Lepidoptera, Gracillariidae

Calybites phasianipennellus - Lepidoptera, Gracillariidae

Cameraria affinis - Lepidoptera, Gracillariidae

Cameraria caryaefoliella - Lepidoptera, Gracillariidae

Cameraria cincinnatiella - Lepidoptera, Gracillariidae: Gregarious oak leafminer

Cameraria hamadryadella - Lepidoptera, Gracillariidae: Solitary oak leafminer

Cameraria ostryarella - Lepidoptera, Gracillariidae

Celpha lacunana - Lepidoptera, Tortricidae

Choreutis pariana - Lepidoptera, Choreutidae: Apple leaf skeletonizer

Choristoneura conflictana - Lepidoptera, Tortricidae: Large aspen tortrix

Choristoneura herbenstreitella - Lepidoptera, Tortricidae

Choristoneura rosaceana - Lepidoptera, Tortricidae: Obliquebanded leafroller

Chrysoesthia sexguttella - Lepidoptera, Gelechiidae

Cimbex americana - Hymenoptera, Cimbicidae: Elm sawfly

Clania crameri - Lepidoptera, Psychidae

Cnaphalcrocis medinalis - Lepidoptera, Pyralidae

Cnephasia asseclana - Lepidoptera, Tortricidae: Flax tortrix

Cochylis posterana - Lepidoptera, Tortricidae

Coelaenomenodera elaeidis - Coleoptera, Chrysomelidae: Oil palm leafminer

Coelaenomenodera perrieri - Coleoptera, Chrysomelidae

Coleophora elaeagnisella - Lepidoptera, Coleophoridae: Speckled case-bearer moth

Coleophora filaginella - Lepidoptera, Coleophoridae

Coleophora flavaginella - Lepidoptera, Coleophoridae

Coleophora malivorella - Lepidoptera, Coleophoridae: Pistol case bearer

Coleophora pruniella - Lepidoptera, Coleophoridae

Coleophora santolinella - Lepidoptera, Coleophoridae

Coleotechnites apicitripunctellus - Lepidoptera, Gelechiidae

Coleotechnites gibsonellus - Lepidoptera, Gelechiidae

Coleotechnites milleri - Lepidoptera, Gelechiidae: Lodgepole needleminer

Coleotechnites starki - Lepidoptera, Gelechiidae: Northern lodgepole needleminer

Coleotechnites thujaella - Lepidoptera, Gelechiidae: Brown arborvitae leafminer

Cornicacoecia lafauryana - Lepidoptera, Tortricidae

Cotesia melanoscela - Hymenoptera, Braconidae

Cremastobombycia solidaginis - Lepidoptera, Gracillariidae

Crobylophora daricella - Lepidoptera, Lyonetiidae

Cryptoblabes bistriga - Lepidoptera, Pyralidae

Cydia leucostoma - Lepidoptera, Tortricidae: Flushworm

Cydia pomonella - Lepidoptera, Tortricidae: Codling moth

Desmia funeralis - Lepidoptera, Pyralidae: Grape leaf folder

Dialectica scalariella - Lepidoptera, Gracillariidae

Diadegma fenestrale - Hymenoptera, Ichneumonidae

Dolichogenidea albipennis - Hymenoptera, Braconidae

Dolichogenidea lacteal - Hymenoptera, Braconidae

Dolichogenidea murinanae - Hymenoptera, Braconidae

Ectoedemia argyropeza - Lepidoptera, Nepticulidae 
Ectoedemia septembrella - Lepidoptera, Nepticulidae

Enargia decolor - Lepidoptera, Noctuidae: Aspen twoleaf tier

Epichorista emphanes - Lepidoptera, Tortricidae: Beech leafroller

Epinotia celtisana - Lepidoptera, Tortricidae

Epinotia sordidana - Lepidoptera, Tortricidae

Epinotia thapsiana - Lepidoptera, Tortricidae

Episimus argutanus - Lepidoptera, Tortricidae

Eulophus abdominalis - Hymenoptera, Eulophidae

Euscrobipalpa suasella - Lepidoptera, Gelechiidae

Exoteleia dodecella - Lepidoptera, Gelechiidae

Exoteleia pinifoliella - Lepidoptera, Gelechiidae: Pine needle miner

Fenusa pusilla - Hymenoptera, Tenthredinidae: Birch leafminer

Fenusa ulmi - Hymenoptera, Tenthredinidae: Elm leafminer

Gibbovalva quadrifasciata - Lepidoptera, Gracillariidae

Glyphodes pyloalis - Lepidoptera, Pyralidae: Mulberry pyralid

Gortyna flavago - Lepidoptera, Noctuidae: Frosted orange

Gracillaria limosella - Lepidoptera, Gracillariidae

Gracillaria syringella - Lepidoptera, Gracillariidae: Lilac leafminer

Gynaephora alpherakii - Lepidoptera, Lymantriidae

Haritalodes derogata - Lepidoptera, Pyralidae: Cotton leaf roller

Herpetogramma bipunctale - Lepidoptera, Pyralidae

Heterarthrus aceris - Hymenoptera, Tenthredinidae

Heterarthrus nemoratus - Hymenoptera, Tenthredinidae: Late birch edgeminer

Heterarthrus wuesteneii - Hymenoptera, Tenthredinidae

Hyblaea puera - Lepidoptera, Hyblaeidae: Teak defoliator

Hydrellia griseola - Diptera, Ephydridae

Hydrellia valida - Diptera, Ephydridae

Hydriomena renunciata - Lepidoptera, Geometridae: Renounced hydriomena

Hypera adspersa - Coleoptera, Curculionidae

Keiferia lycopersicella - Lepidoptera, Gelechiidae: Tomato pinworm

Lethata anophthalma - Lepidoptera, Oecophoridae

Leucoma salicis - Lepidoptera, Lyonetiidae: Satin Moth

Leucoptera coffeella - Lepidoptera, Lyonetiidae: Coffee leafminer

Leucoptera malifoliella - Lepidoptera, Lyonetiidae: Pear leaf blister moth or pear leaf miner

Leucoptera meyricki - Lepidoptera, Lyonetiidae: Coffee leafminer

Liriomyza pusilla - Diptera, Agromyzidae: Serpentine leafminer

Lymantria dispar - Lepidoptera, Lymantriidae: Gypsy moth

Lyonetia clerkella - Lepidoptera, Lyonetiidae: Apple leaf miner

Mahasena corbetti - Lepidoptera, Psychidae: Coconut case caterpillar, Coconut

bagworm, or oilpalm bagworm

Metriochroa latifoliella - Lepidoptera, Gracillariidae: Small olive leafminer

Microgaster subcompleta - Hymenoptera, Braconidae

Mirificarma mulinella - Lepidoptera, Gelechiidae

Ocnerostoma piniariellum - Lepidoptera, Yponomeutidae: Ermine moth

Odites artigena - Lepidoptera, Lecithoceridae 
Omiodes indicata - Lepidoptera, Pyralidae

Onchocephala senegalensis - Coleoptera, Chrysomelidae

Ostrinia nubilalis - Lepidoptera, Pyralidae: European corn borer

Ostrinia obumbratalis - Lepidoptera, Pyralidae: Smartweed borer

Ostrinia penitalis - Lepidoptera, Pyralidae: American lotus borer

Oxicesta geographica - Lepidoptera, Noctuidae: Defoliator moth

Pandemis cerasana - Lepidoptera, Tortricidae: Barred fruit tree tortrix

Pandemis corylana - Lepidoptera, Tortricidae: Chequered fruit tree tortrix

Pandemis dumetana - Lepidoptera, Tortricidae

Parapandemis chondrillana - Lepidoptera, Tortricidae

Papaipema nebris - Lepidoptera, Noctuidae: Stalk borer or common stalk borer

Parectopa robiniella- Lepidoptera, Gracillariidae: Locust digitate leafminer

Parornix anguliferella - Lepidoptera, Gracillariidae

Parornix devoniella - Lepidoptera, Gracillariidae

Parornix geminatella - Lepidoptera, Gracillariidae: Unspotted tentiform leafminer

Parornix kalmiella - Lepidoptera, Gracillariidae

Parornix persicella - Lepidoptera, Gracillariidae

Parornix petiolella - Lepidoptera, Gracillariidae

Parornix scoticella - Lepidoptera, Gracillariidae

Parnara guttata - Lepidoptera, Hesperiidae: Common straight swift

Pholetesor bicolor - Hymenoptera, Braconidae

Pholetesor circumscriptus - Hymenoptera, Braconidae

Pholetesor ornigis - Hymenoptera, Braconidae

Phthorimaea operculella - Lepidoptera: Gelechiidae: Potato tuberworm or potato tuber moth

Phyllocnistis citrella- Lepidoptera, Gracillariidae: Citrus leafminer

Phyllocnistis populiella - Lepidoptera, Gracillariidae: Aspen serpentine leafminer or

Aspen leafminer

Phyllocnistis sorghageniella - Lepidoptera, Gracillariidae

Phyllocnistis tremulella - Lepidoptera, Gracillariidae

Phyllocnistis unipunctella - Lepidoptera, Gracillariidae: Poplar leafminer

Phyllonorycter acerifoliella - Lepidoptera Gracillariidae

Phyllonorycter acernella - Lepidoptera Gracillariidae

Phyllonorycter aeriferella - Lepidoptera Gracillariidae

Phyllonorycter agilella - Lepidoptera Gracillariidae

Phyllonorycter albanotella - Lepidoptera Gracillariidae

Phyllonorycter alnicolella - Lepidoptera Gracillariidae

Phyllonorycter alpine - Lepidoptera Gracillariidae

Phyllonorycter anderidae - Lepidoptera Gracillariidae

Phyllonorycter argentifimbriella - Lepidoptera Gracillariidae

Phyllonorycter argentinotella - Lepidoptera Gracillariidae

Phyllonorycter auronitens - Lepidoptera Gracillariidae

Phyllonorycter basistrigella - Lepidoptera Gracillariidae

Phyllonorycter bicinctella - Lepidoptera Gracillariidae

Phyllonorycter blancardella- Lepidoptera, Gracillariidae: Spotted tentiform leafminer

Phyllonorycter cavella - Lepidoptera, Gracillariidae 
Phyllonorycter celtisella - Lepidoptera Gracillariidae

Phyllonorycter comparella - Lepidoptera Gracillariidae

Phyllonorycter comptoniella - Lepidoptera Gracillariidae

Phyllonorycter connexella - Lepidoptera Gracillariidae

Phyllonorycter coryli - Lepidoptera, Gracillariidae: Nut leaf blister moth

Phyllonorycter corylifoliella - Lepidoptera, Gracillariidae: Hawthorn red midget moth

Phyllonorycter crataegella - Lepidoptera Gracillariidae: Apple blotch leafminer

Phyllonorycter cretata - Lepidoptera Gracillariidae

Phyllonorycter cydoniella - Lepidoptera Gracillariidae

Phyllonorycter cytisella - Lepidoptera Gracillariidae

Phyllonorycter diversella - Lepidoptera Gracillariidae

Phyllonorycter dubitella - Lepidoptera Gracillariidae

Phyllonorycter elmaella - Lepidoptera Gracillariidae: Western tentiform leafminer

Phyllonorycter emberizaepennella - Lepidoptera Gracillariidae

Phyllonorycter endryella - Lepidoptera Gracillariidae

Phyllonorycter ermani - Lepidoptera Gracillariidae

Phyllonorycter felinelle - Lepidoptera Gracillariidae

Phyllonorycter fitchella - Lepidoptera Gracillariidae

Phyllonorycter fragilella - Lepidoptera Gracillariidae

Phyllonorycter froelichiella - Lepidoptera Gracillariidae

Phyllonorycter hancola - Lepidoptera Gracillariidae

Phyllonorycter harrisella - Lepidoptera Gracillariidae

Phyllonorycter heegeriella - Lepidoptera Gracillariidae

Phyllonorycter helianthemella - Lepidoptera Gracillariidae

Phyllonorycter insignitella - Lepidoptera Gracillariidae

Phyllonorycter intermixtus - Lepidoptera Gracillariidae

Phyllonorycter issikii - Lepidoptera Gracillariidae

Phyllonorycter juglandis - Lepidoptera Gracillariidae

Phyllonorycter kearfottella - Lepidoptera Gracillariidae

Phyllonorycter kleemannella - Lepidoptera Gracillariidae

Phyllonorycter lantanella - Lepidoptera Gracillariidae

Phyllonorycter linifoliella - Lepidoptera Gracillariidae

Phyllonorycter lucetiella - Lepidoptera Gracillariidae: Basswood squareblotch miner

Phyllonorycter lucidicostella - Lepidoptera Gracillariidae: Lesser maple leafblotch miner

Phyllonorycter maestingella - Lepidoptera Gracillariidae

Phyllonorycter malella - Lepidoptera, Gracillariidae: Apple tentiform leafminer or spotted tentiform leafminer

Phyllonorycter malimalifoliella - Lepidoptera, Gracillariidae: Spotted tentiform leafminer

Phyllonorycter manni - Lepidoptera Gracillariidae

Phyllonorycter mespilella - Lepidoptera, Gracillariidae: Tentiform leafminer

Phyllonorycter messaniella - Lepidoptera, Gracillariidae: Zellar's midget

Phyllonorycter millierella - Lepidoptera Gracillariidae

Phyllonorycter morrisella - Lepidoptera Gracillariidae

Phyllonorycter nicellii - Lepidoptera Gracillariidae

Phyllonorycter nigrescentella - Lepidoptera Gracillariidae 
Phyllonorycter nipponicella - Lepidoptera Gracillariidae

Phyllonorycter obscuricostella - Lepidoptera Gracillariidae

Phyllonorycter oxyacanthae - Lepidoptera Gracillariidae

Phyllonorycter pastorella - Lepidoptera Gracillariidae

Phyllonorycter platani - Lepidoptera Gracillariidae

Phyllonorycter platanoidella - Lepidoptera Gracillariidae

Phyllonorycter pomifoliella - Lepidoptera Gracillariidae

Phyllonorycter populifoliella - Lepidoptera Gracillariidae

Phyllonorycter propinquinella- Lepidoptera, Gracillariidae: cherry blotchminer

Phyllonorycter pseudolautella - Lepidoptera Gracillariidae

Phyllonorycter pygmaea - Lepidoptera Gracillariidae

Phyllonorycter pyrifoliella - Lepidoptera Gracillariidae

Phyllonorycter quercifoliella - Lepidoptera Gracillariidae

Phyllonorycter quinnata - Lepidoptera Gracillariidae

Phyllonorycter quinqueguttella - Lepidoptera Gracillariidae

Phyllonorycter rajella - Lepidoptera Gracillariidae

Phyllonorycter restrictella - Lepidoptera Gracillariidae

Phyllonorycter ringoniella - Lepidoptera, Gracillariidae: Apple leafminer

Phyllonorycter robiniella - Lepidoptera, Gracillariidae: Horse-chesnut leafminer

Phyllonorycter roboris - Lepidoptera Gracillariidae

Phyllonorycter sagitella - Lepidoptera Gracillariidae

Phyllonorycter salicifoliella - Lepidoptera, Gracillariidae: Aspen blotch leaf miner

Phyllonorycter salictella - Lepidoptera Gracillariidae

Phyllonorycter saportella - Lepidoptera Gracillariidae

Phyllonorycter schreberella - Lepidoptera Gracillariidae

Phyllonorycter scitulella - Lepidoptera Gracillariidae

Phyllonorycter scudderella - Lepidoptera Gracillariidae

Phyllonorycter sorbi - Lepidoptera Gracillariidae

Phyllonorycter sorbicola - Lepidoptera Gracillariidae

Phyllonorycter spinicolella - Lepidoptera Gracillariidae

Phyllonorycter spinolella - Lepidoptera Gracillariidae

Phyllonorycter stettinensis - Lepidoptera Gracillariidae

Phyllonorycter strigulatella - Lepidoptera Gracillariidae

Phyllonorycter tangerensis - Lepidoptera Gracillariidae

Phyllonorycter tenerella - Lepidoptera Gracillariidae

Phyllonorycter tiliacella - Lepidoptera Gracillariidae: Basswood roundblotch miner

Phyllonorycter tremulae - Lepidoptera Gracillariidae

Phyllonorycter tremuloidiella - Lepidoptera, Gracillariidae: Aspen blotchminer

Phyllonorycter triacha - Lepidoptera Gracillariidae

Phyllonorycter trifasciella - Lepidoptera Gracillariidae

Phyllonorycter trinotella - Lepidoptera Gracillariidae

Phyllonorycter tristrigella - Lepidoptera Gracillariidae

Phyllonorycter tritaenianella - Lepidoptera Gracillariidae

Phyllonorycter ulmifoliella - Lepidoptera Gracillariidae

Phyllonorycter viminetorum - Lepidoptera Gracillariidae

Phytoliriomyza variegate - Diptera, Agromyzidae 
Platynota rostrana - Lepidoptera, Tortricidae

Pococera robustella - Lepidoptera, Pyralidae: Pine webworm

Polyconia spinicornis - Coleoptera, Chrysomelidae

Polyhymno luteostrigella - Lepidoptera, Gelechiidae

Povolnya leucapennella - Lepidoptera Gracillariidae

Prays acmonias - Lepidoptera, Plutellidae

Promecotheca cumingii - Coleoptera, Chrysomelidae: coconut leafminer

Promecotheca nuciferae - Coleoptera, Chrysomelidae: Coconut leafminer

Psilocorsis quercicella - Lepidoptera, Oechophoridae

Recurvaria leucatella - Lepidoptera, Gelechiidae: Lesser budmoth

Recurvaria syrictis - Lepidoptera, Gelechiidae

Rhopobota myrtillana - Lepidoptera, Tortricidae

Rhopobota naevana - Lepidoptera, Tortricidae: Hollt tortrix

Rhodoneura vitulla - Lepidoptera, Thyrididae

Rhyacionia frustrana - Lepidoptera, Tortricidae: Nantucket pine tip moth

Rondotia menciana - Lepidoptera, Bombycidae: Mulberry white caterpillar

Rynchaenus pallicornis - Coleoptera, Curculionidae

Rynchaenus salicis - Coleoptera, Curculionidae

Scythropia crataegella - Lepidoptera, Yponomeutidae: Hawthorn moth

Sesamia cretica - Lepidoptera, Noctuidae: Durra stem borer

Shawiana phyllotomae - Hymenoptera, Braconidae

Sparganothis sulfureana - Lepidoptera, Tortricidae: Spragnothis fruitworm

Spilonota lariciana - Lepidoptera, Tortricidae

Spilonota ocellana - Lepidoptera, Tortricidae: Eye-spotted budmoth

Stegobium paniceum - Coleoptera, Anobiidae: Drugstore or bisquit beetle

Stigmella belfragrella - Lepidoptera, Nepticulidae

Stigmella incognitella - Lepidoptera, Nepticulidae

Stigmella malella - Lepidoptera, Nepticulidae: Banded apple pigmy

Stomopteryx nerteria - Lepidoptera, Gelechiidae

Syndemis musculana - Lepidoptera, Tortricidae: Autumn leafroller

Tebenna chodjaevi - Lepidoptera, Choreutidae

Tethea or - Lepidoptera, Thyatiridae: Poplar lutestring

Thyridopteryx ephameraeformis - Lepidoptera, Psychidae

Tischeria decidua - Lepidoptera, Tischeriidae

Tischeria dodonaea - Lepidoptera, Tischeriidae

Tischeria ekebladella - Lepidoptera, Tischeriidae

Tischeria malifoliella - Lepidoptera, Tischeriidae: Apple leaf trumpet miner

Tischeria omissa - Lepidoptera, Tischeriidae

Tortrix viridana - Lepidoptera, Tortricidae: European oak leafroller

Trachys dasi - Coleoptera, Buprestidae

Trachys minuta - Coleoptera, Buprestidae

Zeiraphera griseana - Lepidoptera: Tortricidae: Dingy larch bell

Zenillia roseanae - Diptera, Tachinidae 


\section{Subfamily Eulophinae not in CA or AZ}

\section{Elachertus}

Host:

Acleris variana - Lepidoptera, Tortricidae: Blackheaded budworm or Eastern

blackheaded budworm

Acrobasis caryivorella - Lepidoptera, Pyralidae

Acrocercops dives - Lepidoptera, Gracillariidae

Acronicta megacephala - Lepidoptera, Noctuidae: Poplar grey

Adleria glutinosa - Hymenoptera, Cynipidae

Adoxophyes orana - Lepidoptera, Tortricidae: Summerfruit tortrix

Agonoxena argaula- Lepidoptera, Agonoxenidae: Coconut leafminer

Agonopterix heracliana - Lepidoptera, Depressariidae

Agonopterix hypericella - Lepidoptera, Depressariidae

Agonoxena pyrogramma - Lepidoptera, Agonoxenidae: Coconut flat moth

Amorbia cuneana - Lepidoptera, Tortriciade: Western avocado leafroller

Anacampsis populella - Lepidoptera, Gelechiidae

Ancylis comptana - Lepidoptera, Tortricidae: Strawberry leafroller

Ancylis mitterbacheriana - Lepidoptera, Tortricidae

Ancyloxypha numitor - Lepidoptera, Hesperiidae: Least skipper

Antaeotricha leucillana - Lepidoptera, Oecophoridae: Well-marked fruit worm

Antichloris viridis - Lepidoptera, Arctiidae

Archips argyrospila - Lepidoptera, Tortricidae: Fruittree leafroller

Archips crataegana - Lepidoptera, Tortricidae: Brown oak tortrix

Archips rosana - Lepidoptera, Tortricidae: European leafroller or rose tortrix moth

Archips xylosteana - Lepidoptera, Tortricidae: Brown oak tortrix or variegated golden tortrix

Argyresthia oreasella - Lepidoptera, Yponomeutidae

Argyrotaenia pinatubana - Lepidoptera, Tortricidae: Pine tube moth

Argyrotaenia velutinana - Lepidoptera, Tortricidae: Red-banded leaf roller

Asterocampa clyton - Lepidoptera, Nymphalidae: Tawney Emperor

Barbara colfaxiana - Lepidoptera, Tortricidae: Douglas-fir cone moth

Bedellia somnulentella -Lepidoptera, Lyonetiidae: Sweet potato leafminer

Bena prasinana -Lepidoptera, Noctuidae: Scarce silver-lines

Blastobasis glandulella - Lepidoptera, Coleophoridae

Blastodacna atra - Lepidoptera, Cosmopterigidae: Apple pith moth

Byctiscus betulae - Coleoptera, Rhynchititdae

Cacoecimorpha pronubana - Lepidoptera, Tortricidae: Carnation tortrix

Caloptilia cuculipennella - Lepidoptera, Gracillariidae

Caloptilia packardella - Lepidoptera, Gracillariidae

Caloptilia theivora - Lepidoptera, Gracillariidae

Calpodes ethlius - Lepidoptera, Hesperiidae: Brazilian skipper, canna skipper or larger canna leafroller

Calybites auroguttellus - Lepidoptera, Gracillariidae

Chirosia betuleti - Diptera, Anthomyiidae

Choreutis pariana - Lepidoptera, Choreutidae: Apple leaf skeletonizer

Choristoneura fumiferana - Lepidoptera, Tortricidae: Spruce budworm 
Choristoneura murinana - Lepidoptera, Tortricidae: European fir budworm

Choristoneura rosaceana - Lepidoptera, Tortricidae: Obliquebanded leafroller

Clostera curtula - Lepidoptera, Notodontidae: Chocolate-tip

Cnephasia chrysantheana - Lepidoptera, Tortricidae

Coleophora follicularis - Lepidoptera, Coleophoridae

Coleophora laricella - Lepidoptera, Coleophoridae: Larch casebearer or larch leaf miner

Coleophora limosipennella - Lepidoptera, Coleophoridae

Coleophora pruniella - Lepidoptera, Coleophoridae

Cydia caryana - Lepidoptera, Tortricidae: Hickory shuckworm

Cydia latiferreana - Lepidoptera, Tortricidae: Filbertworm moth

Cydia nigricana - Lepidoptera, Tortricidae: Pea moth

Dasychira plagiata - Lepidoptera, Lymantriidae: Pine tussock moth

Dioryctria abietella - Lepidoptera, Pyralidae: Spruce coneworm or Fir coneworm

Dioryctria zimmermani - Lepidoptera, Pyralidae: Zimmerman pine moth

Dolichogenidea tasmanica - Hymenoptera, Braconidae

Epermenia illigerella - Lepidoptera, Epermeniidae

Epinotia celtisana - Lepidoptera, Tortricidae

Epinotia fraternana - Lepidoptera, Tortricidae

Eublemma gayneri - Lepidoptera, Noctuidae

Eucosma recissoriana - Lepidoptera, Tortricidae: Lodgepole pine cone borer

Eulithis diversilineata - Lepidoptera, Geometridae: Lesser grapevine looper

Eulophus orgyiae - Hymenoptera, Eulophidae

Eupithecia spermaphaga - Lepidoptera, Geometridae: Fir cone looper

Eupoecilia ambiguella - Lepidoptera, Tortricidae: Eurpean grape berry moth

Exoteleia dodecella - Lepidoptera, Gelechiidae

Glena bisulca - Lepidoptera, Geometridae

Gracillaria syringella - Lepidoptera, Gracillariidae: Lilac leafminer

Haritalodes derogata - Lepidoptera, Pyralidae: Cotton leaf roller

Harrisina americana - Lepidoptera, Zygaenidae: Grapeleaf skeletonizer

Heterocampa guttivitta - Lepidoptera, Notodontidae: Maple prominent or saddled

prominent

Homoeocerus pallens - Hemiptera, Coreidae

Lathronympha strigana - Lepidoptera, Tortricidae

Lethata anophthalma - Lepidoptera, Oecophoridae

Lerema accius - Lepidoptera, Hesperiidae: Clouded skipper

Leucoptera coffeella - Lepidoptera, Lyonetiidae: Coffee leafminer

Leucoptera laburnella - Lepidoptera, Lyonetiidae: Laburnum leaf miner

Luffia lapidella - Lepidoptera, Psychidae

Lymantria dispar - Lepidoptera, Lymantriidae: Gypsy Moth

Lymantria monacha - Lepidoptera, Lymantriidae: Black arches

Mamestra brassicae - Lepidoptera, Noctuidae: Cabbage moth

Marmara fasciella - Lepidoptera, Gracillariidae: White pine bark miner

Neaspilota alba - Diptera, Tephritidae

Notocelia roborana - Lepidoptera, Tortricidae

Oidaematophorus paleaceus - Lepidoptera, Pterophoridae

Omiodes indicata - Lepidoptera, Pyralidae 
Orgyia definite - Lepidoptera, Lymantriidae: Definite-marked tussock moth Orgyia leucostigma - Lepidoptera, Lymantriidae: White-marked tussock moth Orgyia pseudotsugata - Lepidoptera, Lymantriidae: Douglas-fir tussock moth Palthis angulalis - Lepidoptera, Noctuidae: Dark-spotted palthis or Spruce harlequin Pandemis cinnamomeana - Lepidoptera, Tortricidae Panoquina ethlius - Lepidoptera, Hesperiidae Panoquina nero - Lepidoptera, Hesperiidae Panoquina sylvicola - Lepidoptera, Hesperiidae: Purple-washed skipper Parectopa robiniella- Lepidoptera, Gracillariidae: Locust digitate leafminer Parornix devoniella - Lepidoptera, Gracillariidae

Parornix geminatella - Lepidoptera, Gracillariidae: Unspotted tentiform leafminer

Perichares philetes - Lepidoptera, Hesperiidae: Green-backed ruby-eye

Perittia obscurepunctella-Lepidoptera, Elachistidae

Phthorimaea operculella - Lepidoptera: Gelechiidae: Potato tuberworm or potato tuber moth

Phyllocnistis citrella- Lepidoptera, Gracillariidae: Citrus leafminer

Phyllonorycter acernella - Lepidoptera Gracillariidae

Phyllonorycter anderidae - Lepidoptera, Gracillariidae

Phyllonorycter blancardella- Lepidoptera, Gracillariidae: Spotted tentiform leafminer

Phyllonorycter coryli - Lepidoptera, Gracillariidae: Nut leaf blister moth

Phyllonorycter emberizaepennella - Lepidoptera Gracillariidae

Phyllonorycter messaniella - Lepidoptera, Gracillariidae: Zellar's midget

Phyllonorycter nicellii - Lepidoptera, Gracillariidae

Phyllonorycter nigrescentella - Lepidoptera, Gracillariidae

Phyllonorycter oxyacanthae - Lepidoptera, Gracillariidae

Phyllonorycter platanoidella - Lepidoptera, Gracillariidae

Phyllonorycter pomonella - Lepidoptera, Gracillariidae

Phyllonorycter sorbi - Lepidoptera, Gracillariidae

Phyllonorycter spinicolella - Lepidoptera, Gracillariidae

Phyllonorycter stettinensis - Lepidoptera, Gracillariidae

Phyllonorycter tenerella - Lepidoptera, Gracillariidae

Platynota idaeusalis - Lepidoptera, Tortricidae: Tufted apple budmoth

Platynota rostrana - Lepidoptera, Tortricidae

Platynota stultana - Lepidoptera, Tortricidae: Omnivorous leafroller

Polychrosis botrana - Lepidoptera, Tortricidae: European grape berry moth or European grapevine moth

Polychrosis viteana - Lepidoptera, Tortricidae: Grape berry moth

Prays acmonias - Lepidoptera, Plutellidae

Proteoteras aesculana - Lepidoptera, Tortricidae: Maple twig borer

Rhopobota myrtillana - Lepidoptera, Tortricidae

Rhyacionia buoliana - Lepidoptera, Tortricidae: European pine shoot moth

Rhyacionia duplana - Lepidoptera, Tortricidae: Pine tip moth

Rhyacionia frustrana - Lepidoptera, Tortricidae: Nantucket pine tip moth

Schizura ipomaeae - Lepidoptera, Notodontidae

Schizura unicornis - Lepidoptera, Notodontidae: Unicorn caterpillar or prominent moth caterpillar 
Scobicia pustulata - Coleoptera, Bostrichidae

Sparganothis pettitana - Lepidoptera, Tortricidae

Sparganothis pilleriana - Lepidoptera, Tortricidae: Long palped tortrix

Sparganothis sulfureana - Lepidoptera, Tortricidae: Spragnothis fruitworm

Sphaeroderma rubidium - Coleoptera, Chrysomelidae

Spilonota ocellana - Lepidoptera, Tortricidae: Eye-spotted budmoth

Spilosoma virginicum - Lepidoptera, Arctiidae

Strepsicrates smithiana - Lepidoptera, Tortricidae

Synanthedon pictipes - Lepidoptera, Sesiidae: Lesse peachtree borer

Tortrix viridana - Lepidoptera, Tortricidae: European oak leafroller

Urbanus proteus - Lepidoptera, Hesperiidae: Long-tailed skipper

Utetheisa pulchella - Lepidoptera, Arctiidae: Crimson speckled moth

Zeiraphera griseana - Lepidoptera: Tortricidae: Dingy larch bell

\section{Dimmockia}

Host:

Acrobasis caryae - Lepidoptera, Pyralidae: Hickory shoot borer

Anacampsis innocuella - Lepidoptera, Gelechiidae: Darkheaded aspen leafroller

Caloptilia sapporensis - Lepidoptera, Gracillariidae

Caloptilia stigmatella - Lepidoptera, Gracillariidae

Chirosia betuleti - Diptera, Anthomyiidae

Cortesia clisiocampae

Cortesia congregate

Cortesia melanoscela - Gypsy Moth parasite

Croesia semipurpurana - Lepidoptera, Tortricidae: Oak leaftier

Dolichogenidea lacteicolor - Hymenoptera, Braconidae

Dolichovespula maculate - Hymenoptera, Vespidae: Baldfaced hornet

Elasmus japonicus - Hymenoptera, Elasmidae

Episimus argutanus - Lepidoptera, Tortricidae

Exorista larvarum - Diptera, Tachinidae

Gelis tenellus - Hymenoptera, Ichnuemonidae

Glyptapanteles lipardis - Hymenoptera, Braconidae

Hyalophora cecropia - Lepidoptera, Saturniidae: Cecropia moth

Hyposoter takagii - Hymenoptera, Ichnuemonidae

Itoplectis conquisitor - Hymenoptera, Ichnuemonidae: White-banded pimpline

Lanugo

Lymantria dispar - Lepidoptera, Lymantriidae: Gypsy Moth

Mastrus annulatus - Hymenoptera, Ichnuemonidae

Meteorus trachynotus - Hymeoptera, Brachonidae

Onchocephala montivaga - Coleoptera, Chrysomelidae

Parnara guttata - Lepidoptera, Hesperiidae: Common straight swift

Phyllonorycter - Lepidoptera, Gracillariidae

Pimpla aethiops - Hymenoptera, Ichnuemonidae

Promecotheca cumingii - Coleoptera, Chrysomelidae: Coconut leafminer

Psychophagus omnivorus - Hymenoptera, Pteromalidae

Sparganothis pettitana - Lepidoptera, Tortricidae 
Sphecodina abbotti - Lepidoptera, Sphingidae: Abbot's sphinx moth

Sphecophaga vesparum - Hymenoptera, Ichnuemonidae

Sphecophaga vesparum burra - Hymenoptera, Ichnuemonidae

Winthemia datanae - Diptera, Tachinidae

\section{Hemiptarsenus}

Host:

Agromyza mobilis - Diptera, Agromyzidae

Agromyza oryzae - Diptera, Agromyzidae: Rice leafminer, Japanese leaf miner or

Japanese rice leafminer

Agromyza parvicornis - Diptera, Agromyzidae: Corn blotch leafminer

Bucculatrix cantabricella - Lepidoptera, Bucculatrigidae

Cerodontha angulata - Diptera, Agromyzidae

Cerodontha iraeos - Diptera, Agromyzidae

Cerodontha iridis - Diptera, Agromyzidae

Cerodontha pygmaea - Diptera, Agromyzidae

Ceutorhynchus assimilis - Coleoptera, Curculionidae: Cabbage seed weevil

Chromatomyia fuscula - Diptera, Agromyzidae

Chromatomyia horticola - Diptera, Agromyzidae: Pea leafminer or garden pea leafminer

Chromatomyia milii - Diptera, Agromyzidae

Chromatomyia nigra - Diptera, Agromyzidae

Chromatomyia primulae - Diptera, Agromyzidae

Chromatomyia syngenesiae - Diptera, Agromyzidae: Chrysanthemum leafminer

Ectoedemia agrimoniae - Lepidoptera, Nepticulidae

Elachista cerusella - Lepidoptera, Elachistidae

Elachista megerlella - Lepidoptera, Elachistidae

Elachista poae - Lepidoptera, Elachistidae

Gortyna flavago - Lepidoptera, Noctuidae: Frosted orange

Heterarthrus nemoratus - Hymenoptera, Tenthredinidae: Late birch edgeminer

Hydrellia griseola - Diptera, Ephydridae

Hypurus bertrandi - Coleoptera, Curculionidae: Portulaca leafmining weevil

Leucoptera laburnella - Lepidoptera, Lyonetiidae: Laburnum leaf miner

Levarchama cryptella - Lepidoptera, Nepticulidae

Levarchama eurema - Lepidoptera, Nepticulidae

Liriomyza bryoniae - Diptera, Agromyzidae: Celery miner

Liriomyza congesta - Diptera, Agromyzidae: Bean leafminer

Liriomyza huidobrensis - Diptera, Agromyzidae: Pea leafminer

Liriomyza pusilla - Diptera, Agromyzidae: Serpentine leafminer

Liriomyza sativae - Diptera, Agromyzidae: Vegetable leafminer

Liriomyza strigata - Diptera, Agromyzidae

Liriomyza trifolii - Diptera, Agromyzidae: American serpentine leafminer

Mompha miscella - Lepidoptera, Momphidae

Meromyza americana - Diptera, Chloropidae: Wheat stem maggot

Ophiomyia phaseoli - Diptera, Agromyzidae: Bean fly

Ostrinia nubilalis - Lepidoptera, Pyralidae: European corn borer

Parafomoria helianthemella - Lepidoptera, Nepticulidae 
Phyllonorycter anderidae - Lepidoptera, Gracillariidae

Phyllonorycter fraxinella - Lepidoptera, Gracillariidae

Phyllonorycter helianthemella - Lepidoptera, Gracillariidae

Phyllonorycter insignitella - Lepidoptera Gracillariidae

Phyllonorycter nigrescentella - Lepidoptera, Gracillariidae

Phyllonorycter sorbi - Lepidoptera, Gracillariidae

Phytoliriomyza variegate - Diptera, Agromyzidae

Phytomyza hendeli - Diptera, Agromyzidae

Phytomyza melana - Diptera, Agromyzidae

Phytomyza minuscule - Diptera, Agromyzidae

Phytomyza plantaginis - Diptera, Agromyzidae

Phytomyza ranunculi - Diptera, Agromyzidae

Prays oleae - Lepidoptera, Plutellidae: Olive kernel borer or olive moth

Pseudonapomyza spicata - Diptera, Agromyzidae: Maize leafminer

Rhamphus oxyacanthae - Coleoptera, Curculionidae

Stagmatophora naviella - Lepidoptera, Cosmopterigidae

Stigmella aeneofasciella - Lepidoptera, Nepticulidae

Stigmella betulicola - Lepidoptera, Nepticulidae

Tomicus piniperda - Coleoptera, Curculionidae: Pine shoot beetle

\section{Colpoclypeus}

Host:

Acleris lipsiana - Lepidoptera, Tortricidae

Acleris maccana - Lepidoptera, Tortricidae

Acleris schalleriana - Lepidoptera, Tortricidae

Adoxophyes orana - Lepidoptera, Tortricidae: Summerfruit tortrix

Ancylis comptana - Lepidoptera, Tortricidae: Strawberry leafroller

Ancylis myrtillana - Lepidoptera, Tortricidae

Archips crataegana - Lepidoptera, Tortricidae: Brown oak tortrix

Archips oporana - Lepidoptera, Tortricidae

Archips rosana - Lepidoptera, Tortricidae: European leafroller or rose tortrix moth

Archips xylosteana - Lepidoptera, Tortricidae: Brown oak tortrix or variegated golden tortrix

Argyrotaenia ljungiana - Lepidoptera, Tortricidae: Grape tortrix

Argyrotaenia velutinana - Lepidoptera, Tortricidae: Red-banded leaf roller

Athalia cordata - Hymenoptera, Tenthredinidae

Cacoecimorpha pronubana - Lepidoptera, Tortricidae: Carnation tortrix

Celypha lacunana - Lepidoptera, Tortricidae: Dark strawberry tortix moth

Choristoneura rosaceana - Lepidoptera, Tortricidae: Obliquebanded leafroller

Cnephasia chrysantheana - Lepidoptera, Tortricidae

Cornicacoecia lafauryana - Lepidoptera, Tortricidae

Eulia ministrana - Lepidoptera, Tortricidae

Eupoecilia ambiguella - Lepidoptera, Tortricidae: Eurpean grape berry moth

Gypsonoma minutana - Lepidoptera, Tortricidae

Hedya nubiferana - Lepidoptera, Tortricidae: Green budmoth

Jordanita budensis - Lepidoptera, Zygaenidae 
Lobesia botrana - Lepidoptera, Tortricidae: Grapevine moth

Lozotaenia forsterana - Lepidoptera, Tortricidae

Lyonetia clerkella - Lepidoptera, Lyonetiidae: Apple leaf miner

Notocelia cynosbatella - Lepidoptera, Tortricidae

Pandemis cerasana - Lepidoptera, Tortricidae: Barred fruit tree tortrix

Pandemis corylana - Lepidoptera, Tortricidae: Chequered fruit tree tortrix

Pandemis dumetana - Lepidoptera, Tortricidae

Pandemis heparana - Lepidoptera, Tortricidae: Dark fruit-tree tortrix

Pandemis pyrusana - Lepidoptera, Tortricidae

Philedonides lunana - Lepidoptera, Tortricidae

Rhopobota myrtillana - Lepidoptera, Tortricidae

Rhopobota naevana - Lepidoptera, Tortricidae: Hollt tortrix

Spilonota ocellana - Lepidoptera, Tortricidae: Eye-spotted budmoth

Triedris paleana - Lepidoptera, Tortricidae

\section{Stenomesius}

Host:

Agrotis crinigera - Lepidoptera, Noctuidae: Poko noctuid moth

Anania verbascalis - Lepidoptera, Pyralidae

Antichloris viridis - Lepidoptera, Arctiidae

Aproaerema modicella - Lepidoptera, Gelechiidae: Groundnut leafminer

Australephestiodes stictella - Lepidoptera, Pyralidae

Bilobata subsecivella - Lepidoptera, Gelechiidae

Brachmia - Lepidoptera, Gelechiidae

Caloptilia azaleella - Lepidoptera, Gracillariidae: Azalea leaf miner

Caloptilia theivora - Lepidoptera, Gracillariidae

Ceramidia butleri - Lepidoptera, Arctiidae

Chilo suppressalia - Lepidoptera, Syntomidae

Choreutis nemorana - Lepidoptera, Choreutidae

Cnaphalocrocis medinalis - Lepidoptera, Pyralidae

Cnephasia longana - Lepidoptera, Tortricidae

Cyphosticha coerulea - Lepidoptera, Gracillariidae

Dialectica scalariella - Lepidoptera, Gracillariidae

Ectoedemia agyropeza - Lepidoptera, Nepticulidae

Gegenes niso - Lepidoptera, Hesperiidae

Helicoverpa armigera - Lepidoptera, Noctuidae: Corn ear worm, tomato grub, tobacco

bidworm or cotton bollworm

Hellula - Lepidoptera, Pyralidae

Leucospilapteryx omissella - Lepidoptera, Gracillariidae

Lyonetia clerkella - Lepidoptera, Lyonetiidae: Apple leaf miner

Macrosiphum euphorbiae - Hemiptera, Aphidiidae: Potato aphid

Mompha ludwigiae - Lepidoptera, Momphidae

Naranga aenescens - Lepidoptera, Noctuidae: Green semilooper

Pelopidas mathias - Lepidoptera, Hesperiidae: Small branded swift, lesser millet skipper, black branded swift

Phloeotribus scarabaeoides - Coleopetera, Scolytidae: olive bark beetle 
Phodoryctis caerulea - Lepidoptera, Gracillariidae

Phyllocnistis citrella- Lepidoptera, Gracillariidae: Citrus leafminer

Phyllonorycter lyoniae - Lepidoptera, Gracillariidae

Phyllonorycter ringoniella - Lepidoptera, Gracillariidae: Apple leafminer

Polythlipta macralis - Lepidoptera, Crambidae

Rhyzopertha dominica - Coleoptera, Bostrichidae: Lesser grain borer

Scirpophaga innotata - Lepidoptera, Pyralidae: White rice stemborer

Stenomesius japonicus - Hymenoptera, Eulophidae

Stigmella aurella - Lepidoptera, Nepticulidae

Stomopteryx nerteria - Lepidoptera, Gelechiidae

\section{Subfamily of Eulophinae not in USA}

\section{Ascotolinx}

Host:

Phyllocnistis citrella- Lepidoptera, Gracillariidae: Citrus leafminer

\section{Meruana}

Host:

Chromatomyia horticola - Diptera, Agromyzidae: Pea leafminer or garden pea leafminer

Chromatomyia syngenesiae - Diptera, Agromyzidae: chrysanthemum leafminer

Liriomyza brassicae - Diptera, Agromyzidae: Serpentine leafminer

Liriomyza sativae - Diptera, Agromyzidae: Vegetable leafminer

Liriomyza trifolii - Diptera, Agromyzidae: American serpentine leafminer

Mohaniella (India only)

Host:

Lepidoptera (lepidopteran leafminers)

\section{Ratzeburgiola}

Host:

Cosmia trapezina - Lepidoptera, Noctuidae: Dun-bar

Cosmopterix pulchrimella - Lepidoptera, Cosmopterigidae

Holocacista rivillei - Lepidoptera, Heliozelidae

Phyllocnistis citrella - Lepidoptera, Gracillariidae: Citrus leafminer

Pyllonorycter corylifoliella - Lepidoptera, Gracillariidae

Phyllonorycter nigrescentella - Lepidoptera, Gracillariidae

Ryhonos (Australia only)

Host:

Acrocercops chionosema - Lepidoptera, Gracillariidae: Macadamia leafminer

Phyllonorycter messaniella - Lepidoptera, Gracillariidae: Zellar's midge

\section{Semielacher}

Host:

Phyllocnistis citrella- Lepidoptera, Gracillariidae: Citrus leafminer 


\section{Subfamily Entedoninae in CA}

\section{Closterocerus}

Host:

Acalyptris loranthella - Lepidoptera, Nepticulidae

Acrocercops breyeri - Lepidoptera, Gracillariidae

Acrocercops dives - Lepidoptera, Gracillariidae

Ageniaspis citricola - Hymenoptera, Encyrtidae

Agromyza nana - Diptera, Agromyzidae

Agromyza oryzae - Diptera, Agromyzidae: Rice leafminer, Japanese leaf miner, Japanese rice leafminer

Agromyza parvicornis - Diptera, Agromyzidae: Corn blotch leafminer

Agromyza rufipes - Diptera, Agromyzidae

Andricus quercusflocci - Hymenoptera, Cynipidae

Antispila nysaefoliella - Lepidoptera, Heliozelidae: Tupelo leafminer

Aonidiella orientalis - Hemiptera, Diaspididae: Oriental scale

Aprostocetus leucopterae - Hymenoptera, Eulophidae

Arge pectoralis - Hymenoptera, Argidae: Birch sawfly

Asamangulia cuspidata - Coleoptera, Chrysomelidae

Asteromyia euthamiae - Diptera, Cecidomyiidae

Aulagromyza populi - Diptera, Agromyzidae

Aulagromyza populicola - Diptera, Agromyzidae

Baliosus ruber - Coleoptera, Chrysomelidae: Basswood leafminer

Blastotere thuiella - Lepidoptera, Agyresthiidae

Brachys aerosus - Coleoptera, Buprestidae

Brachys ovatus - Coleoptera, Buprestidae

Brachys tessellates - Coleoptera, Buprestidae

Bucculatrix canadensisella - Lepidoptera, Bucculatrigidae: Birch skeletonizer

Bucculatrix thurberiella - Lepidoptera, Bucculatrigidae: Cotton leaf perforator

Caligo ilcoxiens - Lepidoptera, Nymphalidae: Owl butterfly

Caliroa cerasi - Hymenoptera, Tenthredinidae: Pear sawfly

Caloptilia ostryaeella - Lepidoptera, Gracillariidae

Calycomyza solidaginis - Diptera, Agromyzidae

Cameraria caryaefoliella - Lepidoptera, Gracillariidae

Cameraria guttifinitella - Lepidoptera, Gracillariidae

Cameraria hamadryadella - Lepidoptera, Gracillariidae: Solitary oak leafminer

Cameraria hamameliella - Lepidoptera, Gracillariidae

Cameraria ulmella - Lepidoptera, Gracillariidae

Chlorops theae - Diptera, Chloropidae

Chromatomyia aprilina - Diptera, Agromyzidae

Chromatomyia horticola - Diptera, Agromyzidae: Pea leafminer or garden pea leafminer

Chromatomyia syngenesiae - Diptera, Agromyzidae: Chrysanthemum leafminer

Chrysocharis lepelleyi - Hymenoptera, Eulophidae

Chrysocharis nepherea - Hymenoptera, Eulophidae

Cirrospilus argei - Hymenoptera, Eulophidae

Cirrospilus cinctiventris - Hymenoptera, Eulophidae

Cirrospilus variegates - Hymenoptera, Eulophidae 
Closterocerus ritchiei - Hymenoptera, Eulophidae

Coelaenomenodera elaeidis - Coleoptera, Chrysomelidae: Oil palm leafminer

Coleophora pruniella - Lepidoptera, Coleophoridae

Coleophora prunifoliae - Lepidoptera, Coleophoridae

Coleophora serratella- Lepidoptera, Coleophoridae: Birch casebearer or cigar casebearer

Coleotechnites thujaella - Lepidoptera, Gelechiidae: Brown arborvitae leafminer

Coptodisca splendoriferella - Lepidoptera, Heliozelidae

Diprion pini - Hymenoptera, Diprionidae

Diprion simile - Hymenoptera, Diprionidae: Pine sawfly

Donacivola saccharella - Lepidoptera, Elachistidae

Elasmus leucopterae - Hymenoptera, Eulpohidae

Eriocrania sparrmannella - Lepidoptera, Eriocraniidae

Exoteleia nepheos - Lepidoptera, Gelechiidae

Exoteleia pinifoliella - Lepidoptera, Gelechiidae: Pine needle miner

Fenusa pusilla - Hymenoptera, Tenthredinidae: Birch leafminer

Fenusa ulmi - Hymenoptera, Tenthredinidae: Elm leafminer

Gilpinia hercyniae - Hymenoptera, Diprionidae: European spruce sawfly

Gilpinia pallida - Hymenoptera, Diprionidae

Gilpinia polytoma - Hymenoptera, Diprionidae

Gracillaria syringella - Lepidoptera, Gracillariidae: Lilac leafminer

Heterarthrus nemoratus - Hymenoptera, Tenthredinidae: Late birch edgeminer

Heterospilus coffeicola - Hymenoptera, Braconidae

Hydrellia griseola - Diptera, Ephydridae

Leucanthiza dircella - Lepidoptera, Gracillariidae

Leucoptera caffeina - Lepidoptera, Lyonetiidae: Coffee leafminer

Leucoptera coffeella - Lepidoptera, Lyonetiidae: Coffee leafminer

Leucoptera coma - Lepidoptera, Lyonetiidae

Leucoptera laburnella - Lepidoptera, Lyonetiidae: Laburnum leaf miner

Leucoptera malifoliella - Lepidoptera, Lyonetiidae: Pear leaf blister moth or pear leaf miner

Leucoptera meyricki- Lepidoptera, Lyonetiidae: Coffee leafminer

Leucoptera sinuella - Lepidoptera, Lyonetiidae

Leucoptera sphenograpta - Lepidoptera, Lyonetiidae

Liocrobyla lobata - Lepidoptera, Gracillariidae

Liriomyza flaveola - Diptera, Agromyzidae

Liriomyza pictella - Diptera, Agromyzidae: Melon leafminer

Liriomyza pseudopygmina - Diptera, Agromyzidae

Liriomyza pusilla - Diptera, Agromyzidae: Serpentine leafminer

Liriomyza sativae - Diptera, Agromyzidae: Vegetable leafminer

Liriomyza strigata - Diptera, Agromyzidae

Liriomyza trifolii - Diptera, Agromyzidae: American serpentine leafminer

Lyonetia clerkella - Lepidoptera, Lyonetiidae: Apple leaf miner

Massalongia rubra - Diptera, Cecidomyiidae

Melanagromyza theae - Diptera, Agromyzidae

Meoneura obscurella - Diptera, Carnidae

Messa hortulana - Hymenoptera, Tenthredinidae 
Metallus rohweri - Hymenoptera, Tenthredinidae

Metopomyza scutellata - Diptera, Agromyzidae

Microrhopala xerene - Coleoptera, Chrysomelidae

Nematus pallipes - Hymenoptera. Tenthredinidae

Neodiprion abbotii - Hymenoptera, Diprionidae: Pine sawfly

Neodiprion excitans - Hymenoptera, Diprionidae: Blackheaded pine sawfly

Neodiprion lecontei - Hymenoptera, Diprionidae: Redheaded pine sawfly

Neodiprion pinetum - Hymenoptera, Diprionidae: White pine sawfly

Neodiprion pratti - Hymenoptera, Diprionidae: Jack pine sawfly or Virginia pine sawfly

Neodiprion rugifrons - Hymenoptera, Diprionidae: Redheaded jack pine sawfly

Neodiprion sertifer-Hymenoptera, Diprionidae: European pine sawfly

Neodiprion swainei - Hymenoptera, Diprionidae: Swaine pine sawfly

Neodiprion virginiana - Hymenoptera, Diprionidae

Neosymydobius chrysolepis - Hemiptera, Aphididae

Ocnerostoma piniariellum - Lepidoptera, Yponomeutidae: Ermine moth

Pachypsylla celtidisgemma - Hemiptera, Psyllidae: Hackberry bud gall psyllid

Pachypsylla celtidisvesiculum - Hemiptera, Psyllidae: Hackberry blistergall psyllid

Paraclemensia acerifoliella - Lepidoptera, Incurvariidae: Maple leafcutter moth

Parectopa robiniella- Lepidoptera, Gracillariidae: Locust digitate leafminer

Parornix geminatella - Lepidoptera, Gracillariidae: Unspotted tentiform leafminer

Parornix persicella - Lepidoptera, Gracillariidae

Phenacaspis pinifoliae - Hemiptera, Diaspididae: Pine needle scale

Pholetesor circumscriptus - Hymenoptera, Braconidae

Pholetesor ornigis - Hymenoptera, Braconidae

Phyllocnistis citrella - Lepidoptera, Gracillariidae: Citrus leafminer

Phyllocnistis insignis - Lepidoptera, Gracillariidae

Phyllocnistis magnoliella - Lepidoptera, Gracillariidae: Magnolia serpentine leafminer

Phyllocnistis populiella - Lepidoptera, Gracillariidae: Aspen serpentine leafminer or

Aspen leafminer

Phyllocnistis tremulella - Lepidoptera, Gracillariidae

Phyllocnistis unipunctella - Lepidoptera, Gracillariidae: Poplar leafminer

Phyllonorycter blancardella- Lepidoptera, Gracillariidae: Spotted tentiform leafminer

Phyllonorycter celtidis - Lepidoptera, Gracillariidae

Phyllonorycter celtisella - Lepidoptera, Gracillariidae

Phyllonorycter crataegella- Lepidoptera Gracillariidae: apple blotch leafminer

Phyllonorycter distentella - Lepidoptera, Gracillariidae

Phyllonorycter froelichiella - Lepidoptera Gracillariidae

Phyllonorycter lucetiella - Lepidoptera Gracillariidae: Basswood squareblotch miner

Phyllonorycter maestingella - Lepidoptera Gracillariidae

Phyllonorycter malimalifoliella - Lepidoptera, Gracillariidae: Spotted tentiform leafminer

Phyllonorycter manni - Lepidoptera, Gracillariidae

Phyllonorycter messaniella - Lepidoptera, Gracillariidae: Zellar's midget

Phyllonorycter platani - Lepidoptera, Gracillariidae

Phyllonorycter populiella - Lepidoptera, Gracillariidae

Phyllonorycter populifoliella - Lepidoptera, Gracillariidae 
Phyllonorycter propinquinella - Lepidoptera, Gracillariidae: cherry blotchminer

Phyllonorycter quercifoliella - Lepidoptera, Gracillariidae

Phyllonorycter salicifoliella - Lepidoptera, Gracillariidae: Aspen blotch leaf miner

Phyllonorycter saliciphaga - Lepidoptera, Gracillariidae

Phyllonorycter spinicolella - Lepidoptera, Gracillariidae

Phyllonorycter tenerella - Lepidoptera, Gracillariidae

Phyllonorycter tremuloidiella - Lepidoptera, Gracillariidae: Aspen blotchminer

Phyllonorycter tristrigella - Lepidoptera, Gracillariidae

Phytoliriomyza clara - Diptera, Agromyzidae

Phytoliriomyza melampyga - Diptera, Agromyzidae

Phytomyza aquilegiae - Diptera, Agromyzidae

Phytomyza heringiana - Diptera, Agromyzidae

Phytomyza ilicicola - Diptera, Agromyzidae: Native holly leafminer

Phytomyza ilicis - Diptera, Agromyzidae: Holly leafminer

Phytomyza minuscule - Diptera, Agromyzidae

Phytomyza obscurella - Diptera, Agromyzidae

Phytomyza phillyreae - Diptera, Agromyzidae

Plagiodera versicolora - Coleoptera, Chrysomelidae

Plesispa nipae - Coleoptera, Hispinae

Pnigalio agraules - Hymenoptera, Eulophidae

Polyconia spinicornis - Coleoptera, Chrysomelidae

Procontarinia matteianna - Diptera, Cecidomyiidae

Profenusa lucifex - Hymenoptera, Tenthredinidae

Profenusa pygmaea - Hymenoptera, Tenthredinidae

Promecotheca cumingii - Coleoptera, Chrysomelidae: Coconut leafminer

Promecotheca nuciferae - Coleoptera, Chrysomelidae: Coconut leafminer

Promecotheca opacicollis - Coleoptera, Hispidae

Promecotheca papuana - Coleoptera, Hispidae

Promecotheca reichei - Coleoptera: Chrysomelidae: Coconut leaf mining beatle or palm leaf mining beetle

Pseudonapomyza spicata - Diptera, Agromyzidae: Maize leafminer

Pygostolus falcatus - Hymenoptera, Braconidae

Rhopalomyia florum - Diptera, Cecidomyiidae

Rynchaenus alni - Coleoptera, Curculionidae

Rynchaenus populi - Coleoptera, Curculionidae

Rynchaenus quercus - Coleoptera, Curculionidae: Oak flea weevil

Rynchaenus rufipes - Coleoptera, Curculionidae

Stigmella carpinella - Lepidoptera, Nepticulidae

Stigmella gossypii - Lepidoptera, Nepticulidae: Cotton leafminer

Stigmella juglandifoliella - Lepidoptera, Nepticulidae: Pecan serpentine leafminer

Stigmella malella- Lepidoptera, Nepticulidae: Banded apple pigmy

Stilbosis ostryaeella - Lepidoptera, Cosmopterigidae: Ironwood leafminer

Targionia vitis - Hemiptera, Diaspididae

Tischeria deciduas - Lepidoptera, Tischeriidae

Tischeria ekebladella - Lepidoptera, Tischeriidae

Tischeria malifoliella - Lepidoptera, Tischeriidae: Apple leaf trumpet miner 
Trachys virescens - Coleoptera, Buprestidae

Tropicomyia flacourthiae - Diptera, Agromyzidae

Tropicomyia theae - Diptera, Agromyzidae: Tea leaf miner

Achrysocharella (subgenus of Closterocerus)

Host:

Chromatomyia aprilina - Diptera, Agromyzidae

Liriomyza sativae- Diptera, Agromyzidae: Vegetable leafminer

Liriomyza trifolii - Diptera, Agromyzidae: American serpentine leafminer

Parectopa robiniella - Lepidoptera, Gracillariidae: Locust digitate leafminer

Trachys virescens - Coleoptera, Buprestidae

\section{Chrysocharis}

Host:

Acalyptris loranthella - Lepidoptera, Nepticulidae

Acidia cognata - Diptera, Tephritidae

Acrocercops brongniardella - Lepidoptera, Gracillariidae

Aethecerus pinifolii - Hymenoptera, Ichneumonidae

Agromyza abiens - Diptera, Agromyzidae

Agromyza albipennis - Diptera, Agromyzidae

Agromyza alnibetulae - Diptera, Agromyzidae

Agromyza aristata - Diptera, Agromyzidae: Elm agromyzid leafminer

Agromyza bicophaga - Diptera, Agromyzidae

Agromyza demeijerei - Diptera, Agromyzidae

Agromyza dipsaci - Diptera, Agromyzidae

Agromyza ferruginosa - Diptera, Agromyzidae

Agromyza flaviceps - Diptera, Agromyzidae

Agromyza frontella - Diptera, Agromyzidae

Agromyza lathyri - Diptera, Agromyzidae

Agromyza myosotidis - Diptera, Agromyzidae

Agromyza nana - Diptera, Agromyzidae

Agromyza nigrescens - Diptera, Agromyzidae

Agromyza nigripes - Diptera, Agromyzidae

Agromyza orobi - Diptera, Agromyzidae

Agromyza oryzae - Diptera, Agromyzidae: Rice leafminer, Japanese leaf miner, Japanese rice leafminer

Agromyza parvicornis - Diptera, Agromyzidae: Corn blotch leafminer

Agromyza potentillae - Diptera, Agromyzidae

Agromyza pseudorufipes - Diptera, Agromyzidae

Agromyza reptans - Diptera, Agromyzidae

Agromyza rufipes - Diptera, Agromyzidae

Agromyza spiraeoidearum - Diptera, Agromyzidae

Agromyza viciae - Diptera, Agromyzidae

Agromyza yanonensis - Diptera, Agromyzidae

Amauromyza flavifrons - Diptera, Agromyzidae

Amauromyza gyrans - Diptera, Agromyzidae 
Amauromyza labiatarum - Diptera, Agromyzidae Amauromyza maculosa - Diptera, Agromyzidae: Chrysanthemum leaf miner Amauromyza morionella - Diptera, Agromyzidae Amauromyza verbasci - Diptera, Agromyzidae Anacampsis populella - Lepidoptera, Gelechiidae Archips argyrospila - Lepidoptera, Tortricidae: Fruittree leafroller

Argyresthia aureoargentella - Lepidoptera, Argyresthiidae: Canadian arborative leafminer

Aulagromyza cornigera - Diptera, Agromyzidae Aulagromyza fulvicornis - Diptera, Agromyzidae Aulagromyza hendeliana - Diptera, Agromyzidae Aulagromyza heringi - Diptera, Agromyzidae Aulagromyza lucens - Diptera, Agromyzidae Aulagromyza orbitalis - Diptera, Agromyzidae Aulagromyza populi - Diptera, Agromyzidae Aulagromyza populicola - Diptera, Agromyzidae Aulagromyza spenceri - Diptera, Agromyzidae Aulagromyza tremulae - Diptera, Agromyzidae Aylax flavicornis - Hymenoptera, Cynipidae Blastotere laevigatella - Lepidoptera, Yponomeutidae: Larch shoot moth Bohemannia pulverosella - Lepidoptera, Nepticulidae

Brachys tessellates - Coleoptera, Buprestidae Bucculatrix ainsliella - Lepidoptera, Bucculatrigidae: Oak skeletonizer Bucculatrix canadensisella - Lepidoptera, Bucculatrigidae: Birch skeletonizer Cameraria aceriella - Lepidoptera, Gracillariidae: Maple leafblotch miner Cameraria agrifoliella - Lepidoptera, Gracillariidae: Live oak leaf blotchminer Cameraria bethunella - Lepidoptera, Gracillariidae: Bethune leafblotch miner or Bethune's leafminer

Cameraria caryaefoliella - Lepidoptera, Gracillariidae

Cameraria corylisella - Lepidoptera, Gracillariidae

Cameraria guttifinitella - Lepidoptera, Gracillariidae

Cameraria hamadryadella - Lepidoptera, Gracillariidae: Solitary oak leafminer

Cameraria hikosanensis - Lepidoptera, Gracillariidae

Cameraria jacintoensis - Lepidoptera, Gracillariidae

Cameraria nemoris - Lepidoptera, Gracillariidae

Cameraria niphonica - Lepidoptera, Gracillariidae

Cameraria picturatella - Lepidoptera, Gracillariidae

Callisto denticulella - Lepidoptera, Gracillariidae

Caloptilia ostryaeella - Lepidoptera, Gracillariidae

Caloptilia ulmi - Lepidoptera, Gracillariidae

Calycomyza artemisiae - Diptera, Agromyzidae

Calycomyza eupatorivora - Diptera, Agromyzidae

Calycomyza humeralis - Diptera, Agromyzidae: Aster leafminer

Calycomyza jucunda - Diptera, Agromyzidae

Calycomyza lantanae - Diptera, Agromyzidae

Calycomyza majuscula - Diptera, Agromyzidae 
Calycomyza malvae - Diptera, Agromyzidae

Calycomyza menthae - Diptera, Agromyzidae

Calycomyza promissa - Diptera, Agromyzidae

Calycomyza solidaginis - Diptera, Agromyzidae

Calycomyza sonchi - Diptera, Agromyzidae

Calycomyza verbenivora - Diptera, Agromyzidae

Cerodontha angulata - Diptera, Agromyzidae

Cerodontha atra - Diptera, Agromyzidae

Cerodontha bimaculata - Diptera, Agromyzidae

Cerodontha bisetiorbita - Diptera, Agromyzidae

Cerodontha caricicola - Diptera, Agromyzidae

Cerodontha caricivora - Diptera, Agromyzidae

Cerodontha dorsalis - Diptera, Agromyzidae: Grass sheathminer

Cerodontha fulvipes - Diptera, Agromyzidae

Cerodontha incise - Diptera, Agromyzidae

Cerodontha iraeos - Diptera, Agromyzidae

Cerodontha iridis - Diptera, Agromyzidae

Cerodontha morose - Diptera, Agromyzidae

Cerodontha okazakii - Diptera, Agromyzidae

Cerodontha pygmaea - Diptera, Agromyzidae

Cerodontha sasakawai - Diptera, Agromyzidae

Ceutorhynchus contractus - Coleoptera, Curculionidae: Cabbage leaf weevil

Chlorops novakii - Diptera, Chloropidae

Choristoneura murinana - Lepidoptera, Tortricidae: European fir budworm

Chromatomyia aprilina - Diptera, Agromyzidae

Chromatomyia chamaemetabola - Diptera, Agromyzidae

Chromatomyia cinnae - Diptera, Agromyzidae

Chromatomyia fuscula - Diptera, Agromyzidae

Chromatomyia gregaria - Diptera, Agromyzidae

Chromatomyia horticola - Diptera, Agromyzidae: Pea leafminer or garden pea leafminer

Chromatomyia ixeridopsis - Diptera, Agromyzidae

Chromatomyia kluanensis - Diptera, Agromyzidae

Chromatomyia lactuca - Diptera, Agromyzidae

Chromatomyia linnaeae - Diptera, Agromyzidae

Chromatomyia lonicerae - Diptera, Agromyzidae

Chromatomyia milii - Diptera, Agromyzidae

Chromatomyia nigra - Diptera, Agromyzidae

Chromatomyia nigrilineata - Diptera, Agromyzidae

Chromatomyia periclymeni - Diptera, Agromyzidae

Chromatomyia poae - Diptera, Agromyzidae

Chromatomyia primulae - Diptera, Agromyzidae

Chromatomyia pseudomilii - Diptera, Agromyzidae

Chromatomyia ramosa - Diptera, Agromyzidae

Chromatomyia scabiosae - Diptera, Agromyzidae

Chromatomyia shepherdiana - Diptera, Agromyzidae

Chromatomyia suikazurae - Diptera, Agromyzidae 
Chromatomyia symphoricarpi - Diptera, Agromyzidae

Chromatomyia syngenesiae- Diptera, Agromyzidae: Chrysanthemum leafminer

Chromatomyia thermarum - Diptera, Agromyzidae

Chromatomyia tiarellae - Diptera, Agromyzidae

Chromatomyia torrentium - Diptera, Agromyzidae

Chrysoesthia drurella - Lepidoptera, Gelechiidae

Chrysoesthia sexguttella - Lepidoptera, Gelechiidae

Cimbex americana - Hymenoptera, Cimbicidae: Elm sawfly

Coccinella vigintiquatuorpunctata - Coleoptera, Coccinellidae

Colastes braconius - Hymenoptera, Braconidae

Coleophora alticolella - Lepidoptera, Coleophoridae

Coleophora flavipennella - Lepidoptera, Coleophoridae

Coleophora ibipennella - Lepidoptera, Coleophoridae

Coleophora laricella- Lepidoptera, Coleophoridae: Larch casebearer or larch leaf miner

Coleophora lusciniaepennella - Lepidoptera, Coleophoridae

Coleophora lutipennella - Lepidoptera, Coleophoridae: Oak case-bearer

Coleophora ostryae - Lepidoptera, Coleophoridae

Coleophora pruniella - Lepidoptera, Coleophoridae

Coleophora serratella- Lepidoptera, Coleophoridae: Birch casebearer or cigar casebearer

Coleotechnites milleri - Lepidoptera, Gelechiidae: Lodgepole needleminer

Coleotechnites thujaella - Lepidoptera, Gelechiidae: Brown arborvitae leafminer

Copidosoma deceptor - Hymenoptera, Encyrtidae

Coptodisca arbutiella - Lepidoptera, Heliozelidae

Coptodisca splendoriferella - Lepidoptera, Heliozelidae

Cordilurina albipes - Diptera, Anthomyiidae

Crinopteryx familiella - Lepidoptera, Crinopterygidae

Dibolia borealis - Coleoptera, Chrysomelidae

Diplolepis lens - Hymenoptera, Cynipidae

Diplolepis rosaefolii - Hymenoptera, Cynipidae

Dolichogenidea californica - Hymenoptera, Braconidae

Donacivola saccharella - Lepidoptera, Elachistidae

Ectoedemia albifasciella - Lepidoptera, Nepticulidae

Ectoedemia argyropeza - Lepidoptera, Nepticulidae

Ectoedemia heringella - Lepidoptera, Nepticulidae

Ectoedemia minimella - Lepidoptera, Nepticulidae

Ectoedemia occultella - Lepidoptera, Nepticulidae

Ectoedemia platanella - Lepidoptera, Nepticulidae: Sycamore leafblotch miner

Ectoedemia rubivora - Lepidoptera, Nepticulidae

Ectoedemia spinosella - Lepidoptera, Nepticulidae

Ectoedemia subbimaculella - Lepidoptera, Nepticulidae

Elachista cerusella - Lepidoptera, Elachistidae

Elachista pomerana - Lepidoptera, Elachistidae

Emmetia angusticolella - Lepidoptera, Tischeriidae

Emmetia heinemanni - Lepidoptera, Tischeriidae

Emmetia marginea - Lepidoptera, Tischeriidae

Enteucha acetosae - Lepidoptera, Nepticulidae 
Epinotia meritana - Lepidoptera, Tortricidae: White fir needleminer

Epinotia thapsiana - Lepidoptera, Tortricidae

Eriocrania sparrmannella - Lepidoptera, Eriocraniidae

Euleia heraclei - Diptera, Tephritidae: Celery fly

Fenusa dohrnii - Hymenoptera, Tenthredinidae: European alder leafminer

Fenusa pusilla - Hymenoptera, Tenthredinidae: Birch leafminer

Fenusa ulmi - Hymenoptera, Tenthredinidae: Elm leafminer

Fomoria septembrella - Lepidoptera, Nepticulidae

Galiomyza galiivora - Diptera, Agromyzidae

Galiomyza morio - Diptera, Agromyzidae

Gilpinia hercyniae - Hymenoptera, Diprionidae: spruce sawfly

Gracillaria japonica - Lepidoptera, Gracillariidae

Gracillaria syringella - Lepidoptera, Gracillariidae: Lilac leafminer

Haplodiplosis marginata - Lepidoptera, Cecidomyiidae: Saddle gall midge

Haritalodes derogata - Lepidoptera, Pyralidae: Cotton leaf roller

Henosepilachna vigintioctopunctata - Coleoptera, Coccinellidae: Twentysix-spotted

potato ladybird

Heterarthrus aceris - Hymenoptera, Tenthredinidae

Heterarthrus nemoratus - Hymenoptera, Tenthredinidae: Late birch edgeminer

Heterarthrus vegans - Hymenoptera, Tenthredinidae

Hispoleptis subfasciata - Coleoptera, Chrysomelidae

Holocacista rivillei - Lepidoptera, Heliozelidae

Hydrellia griseola - Diptera, Ephydridae

Japanagromyza inaequalis - Diptera, Agromyzidae

Japanagromyza polygoni - Diptera, Agromyzidae

Keiferia lycopersicella - Lepidoptera, Gelechiidae: Tomato pinworm

Leucanthiza dircella - Lepidoptera, Gracillariidae

Leucoptera albella - Lepidoptera, Lyonetiidae

Leucoptera caffeina - Lepidoptera, Lyonetiidae: Coffee leafminer

Leucoptera coffeella - Lepidoptera, Lyonetiidae: Coffee leafminer

Leucoptera laburnella - Lepidoptera, Lyonetiidae: Laburnum leaf miner

Leucoptera lathyrifoliella - Lepidoptera, Lyonetiidae

Leucoptera lotella - Lepidoptera, Lyonetiidae

Leucoptera lustratella - Lepidoptera, Lyonetiidae

Leucoptera malifoliella - Lepidoptera, Lyonetiidae: Pear leaf blister moth or pear leaf miner

Leucoptera meyricki- Lepidoptera, Lyonetiidae: Coffee leafminer

Leucoptera sinuella - Lepidoptera, Lyonetiidae

Liriomyza amoena - Diptera, Agromyzidae

Liriomyza artemisicola - Diptera, Agromyzidae

Liriomyza asterivora - Diptera, Agromyzidae

Liriomyza bahamondesi - Diptera, Agromyzidae

Liriomyza borealis - Diptera, Agromyzidae

Liriomyza brassicae - Diptera, Agromyzidae: Serpentine leafminer

Liriomyza bryoniae- Diptera, Agromyzidae: Celery miner

Liriomyza commelinae - Diptera, Agromyzidae 
Liriomyza congesta - Diptera, Agromyzidae: Bean leafminer

Liriomyza eupatorii - Diptera, Agromyzidae

Liriomyza flaveola - Diptera, Agromyzidae

Liriomyza fricki - Diptera, Agromyzidae

Liriomyza huidobrensis- Diptera, Agromyzidae: Pea leafminer

Liriomyza imurai - Diptera, Agromyzidae

Liriomyza katoi - Diptera, Agromyzidae

Liriomyza lathyri - Diptera, Agromyzidae

Liriomyza occipitalis - Diptera, Agromyzidae

Liriomyza pictella - Diptera, Agromyzidae: Melon leafminer

Liriomyza ptarmicae - Diptera, Agromyzidae

Liriomyza pusilla - Diptera, Agromyzidae: Serpentine leafminer

Liriomyza quadrata - Diptera, Agromyzidae

Liriomyza sativae - Diptera, Agromyzidae: Vegetable leafminer

Liriomyza schmidti - Diptera, Agromyzidae

Liriomyza smilacinae - Diptera, Agromyzidae

Liriomyza sonchi - Diptera, Agromyzidae

Liriomyza sorosis - Diptera, Agromyzidae

Liriomyza strigata - Diptera, Agromyzidae

Liriomyza takakoae - Diptera, Agromyzidae

Liriomyza tanaceti - Diptera, Agromyzidae

Liriomyza taraxaci - Diptera, Agromyzidae

Liriomyza trifoliearum - Diptera, Agromyzidae

Liriomyza trifolii - Diptera, Agromyzidae: American serpentine leafminer

Liriomyza virgo - Diptera, Agromyzidae

Lochmaea caprea - Lepidoptera, Chrysomelidae: Willow leaf beetle

Lyonetia clerkella - Lepidoptera, Lyonetiidae: Apple leaf miner

Lyonetia prunifoliella - Lepidoptera, Lyonetiidae

Masakimyia pustulae - Diptera, Cecidomyiidae: Euonymus gall midge

Mayetiola destructor - Diptera, Cecidomyiidae: Hessian fly

Melanagromyza cunctans - Diptera, Agromyzidae

Melanagromyza haba - Diptera, Agromyzidae

Melanagromyza virens - Diptera, Agromyzidae

Melanagromyza viridis - Diptera, Agromyzidae

Messa glaucopis - Hymenoptera, Tenthredinidae

Messa hortulana - Hymenoptera, Tenthredinidae

Messa nana - Hymenoptera, Tenthredinidae: Early birch leaf edgeminer

Messa populifoliella - Hymenoptera, Tenthredinidae

Metopomyza scutellata - Diptera, Agromyzidae

Metriochroa latifoliella - Lepidoptera, Gracillariidae: Small olive leafminer

Microgaster globate - Hymenoptera, Braconidae

Microterys masii - Hymenoptera, Encyrtidae

Napomyza lateralis - Diptera, Agromyzidae

Napomyza xylostei - Diptera, Agromyzidae

Nemorimyza posticata - Diptera, Agromyzidae

Neolithocolletis hikomonticola - Lepidoptera, Gracillariidae 
Neuroterus quercusminutissimus - Hymenoptera, Cynipidae

Omiodes indicata - Lepidoptera, Pyralidae

Ophiomyia camarae - Diptera, Agromyzidae: Herringbone leaf-mining fly

Ophiomyia cunctata - Diptera, Agromyzidae

Ophiomyia curvipalpis - Diptera, Agromyzidae

Ophiomyia maura - Diptera, Agromyzidae

Ophiomyia spencerella - Diptera, Agromyzidae: Bean-stem maggot or beanfly

Ophiomyia texana - Diptera, Agromyzidae

Opius caesus - Hymenoptera, Braconidae

Palaeocimbex quadrimaculata - Hymenoptera, Cimbicidae

Pammene tsugae - Lepidoptera, Tortricidae

Parallelomma medium - Diptera, Anthomyiidae

Parectopa geometropis - Lepidoptera, Gracillariidae

Parectopa robiniella - Lepidoptera Gracillariidae: Locust digitate leafminer

Parornix alni - Lepidoptera Gracillariidae

Parornix devoniella - Lepidoptera, Gracillariidae

Pholetesor circumscriptus - Hymenoptera, Braconidae

Pholetesor ornigis - Hymenoptera, Braconidae

Phyllocnistis citrella - Lepidoptera, Gracillariidae: Citrus leafminer

Phyllocnistis populiella - Lepidoptera, Gracillariidae: Aspen serpentine leafminer or

Aspen leafminer

Phyllocnistis saligna - Lepidoptera, Gracillariidae

Phyllocnistis tremulella - Lepidoptera, Gracillariidae

Phyllocnistis unipunctella - Lepidoptera, Gracillariidae: Poplar leafminer

Phyllocnistis xenia - Lepidoptera, Gracillariidae

Phyllocolpa leucosticte - Hymenoptera, Tenthredinidae

Phyllonorycter aceracerarum - Lepidoptera, Gracillariidae

Phyllonorycter acerifoliella - Lepidoptera, Gracillariidae

Phyllonorycter acernella - Lepidoptera Gracillariidae

Phyllonorycter alnicolella - Lepidoptera, Gracillariidae

Phyllonorycter alpine - Lepidoptera, Gracillariidae

Phyllonorycter anderidae - Lepidoptera, Gracillariidae

Phyllonorycter bicinctella - Lepidoptera, Gracillariidae

Phyllonorycter blancardella- Lepidoptera, Gracillariidae: Spotted tentiform leafminer

Phyllonorycter carpini - Lepidoptera, Gracillariidae

Phyllonorycter cavella - Lepidoptera, Gracillariidae

Phyllonorycter celtisella - Lepidoptera, Gracillariidae

Phyllonorycter comparella - Lepidoptera, Gracillariidae

Phyllonorycter connexella - Lepidoptera, Gracillariidae

Phyllonorycter corylifoliella - Lepidoptera, Gracillariidae: Hawthorn red midget moth

Phyllonorycter crataegella- Lepidoptera Gracillariidae: Apple blotch leafminer

Phyllonorycter cydoniella - Lepidoptera Gracillariidae

Phyllonorycter dubitella - Lepidoptera, Gracillariidae

Phyllonorycter elmaella - Lepidoptera Gracillariidae: Western tentiform leafminer

Phyllonorycter emberizaepennella - Lepidoptera Gracillariidae

Phyllonorycter fagifolia - Lepidoptera, Gracillariidae 
Phyllonorycter froelichiella - Lepidoptera Gracillariidae

Phyllonorycter hancola - Lepidoptera, Gracillariidae

Phyllonorycter harrisella - Lepidoptera, Gracillariidae

Phyllonorycter heegeriella - Lepidoptera Gracillariidae

Phyllonorycter helianthemella - Lepidoptera, Gracillariidae

Phyllonorycter insignitella - Lepidoptera Gracillariidae

Phyllonorycter issikii - Lepidoptera Gracillariidae

Phyllonorycter jezoniella - Lepidoptera Gracillariidae

Phyllonorycter joannisi - Lepidoptera Gracillariidae

Phyllonorycter jozanae - Lepidoptera Gracillariidae

Phyllonorycter kleemannella - Lepidoptera Gracillariidae

Phyllonorycter laciniatae - Lepidoptera Gracillariidae

Phyllonorycter lantanella - Lepidoptera Gracillariidae

Phyllonorycter lautella - Lepidoptera Gracillariidae

Phyllonorycter leucocorona - Lepidoptera Gracillariidae

Phyllonorycter lucetiella - Lepidoptera Gracillariidae: Basswood squareblotch miner

Phyllonorycter lyoniae - Lepidoptera Gracillariidae

Phyllonorycter maestingella - Lepidoptera Gracillariidae

Phyllonorycter malimalifoliella - Lepidoptera, Gracillariidae: Spotted tentiform leafminer

Phyllonorycter manni - Lepidoptera, Gracillariidae

Phyllonorycter mespilella - Lepidoptera, Gracillariidae: Tentiform leafminer

Phyllonorycter messaniella - Lepidoptera, Gracillariidae: Zellar's midget

Phyllonorycter nicellii - Lepidoptera, Gracillariidae

Phyllonorycter nigrescentella - Lepidoptera, Gracillariidae

Phyllonorycter nipponicella - Lepidoptera Gracillariidae

Phyllonorycter orientalis - Lepidoptera Gracillariidae: Apple leaf mining moth

Phyllonorycter oxyacanthae - Lepidoptera, Gracillariidae

Phyllonorycter padella - Lepidoptera Gracillariidae

Phyllonorycter platani - Lepidoptera, Gracillariidae

Phyllonorycter platanoidella - Lepidoptera, Gracillariidae

Phyllonorycter pomifoliella - Lepidoptera, Gracillariidae

Phyllonorycter populifoliella - Lepidoptera, Gracillariidae

Phyllonorycter propinquinella- Lepidoptera, Gracillariidae: cherry blotchminer

Phyllonorycter pyrifoliella - Lepidoptera Gracillariidae

Phyllonorycter quercifoliella - Lepidoptera, Gracillariidae

Phyllonorycter quinnata - Lepidoptera, Gracillariidae

Phyllonorycter rajella - Lepidoptera, Gracillariidae

Phyllonorycter ringoniella - Lepidoptera, Gracillariidae: Apple leafminer

Phyllonorycter roboris - Lepidoptera, Gracillariidae

Phyllonorycter salicicolella - Lepidoptera Gracillariidae

Phyllonorycter salicifoliella - Lepidoptera, Gracillariidae: Aspen blotch leaf miner

Phyllonorycter salictella - Lepidoptera Gracillariidae

Phyllonorycter salictella viminiella - Lepidoptera, Gracillariidae

Phyllonorycter saportella - Lepidoptera Gracillariidae

Phyllonorycter schreberella - Lepidoptera Gracillariidae 
Phyllonorycter sorbi - Lepidoptera, Gracillariidae

Phyllonorycter sorbicola - Lepidoptera, Gracillariidae

Phyllonorycter spinicolella - Lepidoptera, Gracillariidae

Phyllonorycter spinolella - Lepidoptera, Gracillariidae

Phyllonorycter stettinensis - Lepidoptera, Gracillariidae

Phyllonorycter strigulatella - Lepidoptera, Gracillariidae

Phyllonorycter tenerella - Lepidoptera, Gracillariidae

Phyllonorycter tremuloidiella - Lepidoptera, Gracillariidae: Aspen blotchminer

Phyllonorycter tristrigella - Lepidoptera, Gracillariidae

Phyllonorycter turugisana - Lepidoptera, Gracillariidae

Phyllonorycter ulmifoliella - Lepidoptera, Gracillariidae

Phyllonorycter viburni - Lepidoptera, Gracillariidae

Phyllonorycter viminetorum - Lepidoptera, Gracillariidae

Phyllonorycter watanabei - Lepidoptera, Gracillariidae

Phytobia sonderupi - Diptera, Agromyzidae

Phytoliriomyza clara - Diptera, Agromyzidae

Phytoliriomyza felti - Diptera, Agromyzidae

Phytoliriomyza hilarella - Diptera, Agromyzidae

Phytoliriomyza melampyga - Diptera, Agromyzidae

Phytoliriomyza variegate - Diptera, Agromyzidae

Phytomyza aconite - Diptera, Agromyzidae

Phytomyza aegopodii - Diptera, Agromyzidae

Phytomyza affinis - Diptera, Agromyzidae

Phytomyza agromyzina - Diptera, Agromyzidae

Phytomyza albiceps - Diptera, Agromyzidae

Phytomyza albimargo - Diptera, Agromyzidae

Phytomyza alpine - Diptera, Agromyzidae

Phytomyza angelicae - Diptera, Agromyzidae

Phytomyza angelicastri - Diptera, Agromyzidae

Phytomyza aquilegiae - Diptera, Agromyzidae

Phytomyza aquilegiana - Diptera, Agromyzidae: Columbine leafminer

Phytomyza aquilegivora - Diptera, Agromyzidae: Columbine leafminer

Phytomyza aralivora - Diptera, Agromyzidae

Phytomyza archangelicae - Diptera, Agromyzidae

Phytomyza artemisivora - Diptera, Agromyzidae

Phytomyza brunnipes - Diptera, Agromyzidae

Phytomyza calthivora - Diptera, Agromyzidae

Phytomyza calthophila - Diptera, Agromyzidae

Phytomyza chaerophylli - Diptera, Agromyzidae

Phytomyza cicutae - Diptera, Agromyzidae

Phytomyza ciliolate - Diptera, Agromyzidae

Phytomyza cirsii - Diptera, Agromyzidae

Phytomyza citisi - Diptera, Agromyzidae

Phytomyza columbiana - Diptera, Agromyzidae

Phytomyza conyzae - Diptera, Agromyzidae

Phytomyza crassiseta - Diptera, Agromyzidae 
Phytomyza decidua - Diptera, Agromyzidae

Phytomyza delphinivora - Diptera, Agromyzidae: Larkspur leafminer

Phytomyza dryoptericola - Diptera, Agromyzidae

Phytomyza eupatorii - Diptera, Agromyzidae

Phytomyza fulgens - Diptera, Agromyzidae

Phytomyza geniculata - Diptera, Agromyzidae

Phytomyza gentianae - Diptera, Agromyzidae

Phytomyza glechomae - Diptera, Agromyzidae

Phytomyza heringiana - Diptera, Agromyzidae

Phytomyza hypophylla - Diptera, Agromyzidae

Phytomyza ilicicola - Diptera, Agromyzidae: Native holly leafminer

Phytomyza ilicis - Diptera, Agromyzidae: Holly leafminer

Phytomyza japonica - Diptera, Agromyzidae

Phytomyza jucunda - Diptera, Agromyzidae

Phytomyza krygeri - Diptera, Agromyzidae

Phytomyza lappina - Diptera, Agromyzidae

Phytomyza lycopi - Diptera, Agromyzidae

Phytomyza marginella - Diptera, Agromyzidae

Phytomyza melana - Diptera, Agromyzidae

Phytomyza merula - Diptera, Agromyzidae

Phytomyza messaniella - Diptera, Agromyzidae

Phytomyza minuscula - Diptera, Agromyzidae

Phytomyza mitellae - Diptera, Agromyzidae

Phytomyza mylini - Diptera, Agromyzidae

Phytomyza myosotica - Diptera, Agromyzidae

Phytomyza nigritella - Diptera, Agromyzidae

Phytomyza notata - Diptera, Agromyzidae

Phytomyza obscura - Diptera, Agromyzidae

Phytomyza obscurella - Diptera, Agromyzidae

Phytomyza oreas - Diptera, Agromyzidae

Phytomyza origami - Diptera, Agromyzidae

Phytomyza ovalis - Diptera, Agromyzidae

Phytomyza paniculatae - Diptera, Agromyzidae

Phytomyza pastinacae - Diptera, Agromyzidae

Phytomyza pauliloewii - Diptera, Agromyzidae

Phytomyza penstemonis - Diptera, Agromyzidae

Phytomyza peregrine - Diptera, Agromyzidae

Phytomyza persicae - Diptera, Agromyzidae

Phytomyza petoei - Diptera, Agromyzidae

Phytomyza plantaginis - Diptera, Agromyzidae

Phytomyza platensis - Diptera, Agromyzidae

Phytomyza plumiseta - Diptera, Agromyzidae

Phytomyza podagrariae - Diptera, Agromyzidae

Phytomyza prava - Diptera, Agromyzidae

Phytomyza pubicornis - Diptera, Agromyzidae

Phytomyza pullula - Diptera, Agromyzidae 
Phytomyza pulvinariae - Diptera, Agromyzidae

Phytomyza rajella - Diptera, Agromyzidae

Phytomyza ranunculi - Diptera, Agromyzidae

Phytomyza rydeni - Diptera, Agromyzidae

Phytomyza saniculae - Diptera, Agromyzidae

Phytomyza saxifragae - Diptera, Agromyzidae

Phytomyza saximontana - Diptera, Agromyzidae

Phytomyza scopulina - Diptera, Agromyzidae

Phytomyza senecionella - Diptera, Agromyzidae

Phytomyza sii - Diptera, Agromyzidae

Phytomyza silai - Diptera, Agromyzidae

Phytomyza solidaginis - Diptera, Agromyzidae

Phytomyza sorbi - Diptera, Agromyzidae

Phytomyza spinaciae - Diptera, Agromyzidae

Phytomyza spondylii - Diptera, Agromyzidae

Phytomyza subtilis - Diptera, Agromyzidae

Phytomyza symphyti - Diptera, Agromyzidae

Phytomyza tamui - Diptera, Agromyzidae

Phytomyza tetrasticha - Diptera, Agromyzidae

Phytomyza thalictrivora - Diptera, Agromyzidae

Phytomyza thysselini - Diptera, Agromyzidae

Phytomyza thysselinivora - Diptera, Agromyzidae

Phytomyza tlingitia - Diptera, Agromyzidae

Phytomyza tordylii - Diptera, Agromyzidae

Phytomyza trollii - Diptera, Agromyzidae

Phytomyza tundrensis - Diptera, Agromyzidae

Phytomyza tussilaginis - Diptera, Agromyzidae

Phytomyza vitalbae - Diptera, Agromyzidae

Phytomyza vomitoriae - Diptera, Agromyzidae

Phytomyza williamsoni - Diptera, Agromyzidae

Prays oleae - Lepidoptera, Plutellidae: Olive kernel borer or olive moth

Profenusa pygmaea - Hymenoptera, Tenthredinidae

Profenusa thomsoni - Hymenoptera, Tenthredinidae: Amber marked birch leafminer or amber marked leafminer

Protolithocolletis lathyri - Lepidoptera, Gracillariidae

Pseudonapomyza atra - Diptera, Agromyzidae

Pseudonapomyza spicata - Diptera, Agromyzidae: Maize leafminer

Rhamphus pulicarius - Coleoptera, Curculionidae

Rhopalomyia libocedri - Diptera, Cecidomyiidae

Rynchaenus alni - Coleoptera, Curculionidae

Rynchaenus aterrhimus - Coleoptera, Curculionidae

Rynchaenus fagi - Coleoptera, Curculionidae

Rynchaenus japonicus - Coleoptera, Curculionidae

Rynchaenus mutabilis - Coleoptera, Curculionidae

Rynchaenus pallicornis - Coleoptera, Curculionidae

Rynchaenus populi - Coleoptera, Curculionidae 
Rynchaenus quercus - Coleoptera, Curculionidae: Oak flea weevil

Rynchaenus rufipes - Coleoptera, Curculionidae

Rynchaenus rusci - Coleoptera, Curculionidae

Rynchaenus salicis - Coleoptera, Curculionidae

Rynchaenus sanguinipes - Coleoptera, Curculionidae

Rynchaenus subfasciatus - Coleoptera, Curculionidae

Rynchaenus takabayashii - Coleoptera, Curculionidae

Rynchaenus testaceus - Coleoptera, Curculionidae

Scaptomyza adusta - Diptera, Drosophilidae

Scaptomyza flava - Diptera, Drosophilidae

Scaptomyza graminum - Diptera, Drosophilidae

Scolioneura betuleti - Hymenoptera, Tenthredinidae

Silliana hommei - Hymenoptera, Tenthredinidae

Simplimorpha promissa - Lepidoptera, Nepticulidae

Spilonota ocellana - Lepidoptera, Tortricidae: Eye-spotted budmoth

Stigmella aceris - Lepidoptera, Nepticulidae

Stigmella aeneofasciella - Lepidoptera, Nepticulidae

Stigmella alnetella - Lepidoptera, Nepticulidae

Stigmella anomalella - Lepidoptera, Nepticulidae: Rose leafminer

Stigmella assimilella - Lepidoptera, Nepticulidae

Stigmella atricapitella - Lepidoptera, Nepticulidae

Stigmella aurella - Lepidoptera, Nepticulidae

Stigmella auromarginella - Lepidoptera, Nepticulidae

Stigmella betulicola - Lepidoptera, Nepticulidae

Stigmella caradjai - Lepidoptera, Nepticulidae

Stigmella catharticella - Lepidoptera, Nepticulidae

Stigmella centifoliella - Lepidoptera, Nepticulidae

Stigmella confusella - Lepidoptera, Nepticulidae

Stigmella crataegella - Lepidoptera, Nepticulidae

Stigmella floslactella - Lepidoptera, Nepticulidae

Stigmella freyella - Lepidoptera, Nepticulidae

Stigmella hemargyrella - Lepidoptera, Nepticulidae

Stigmella hybnerella - Lepidoptera, Nepticulidae

Stigmella incognitella - Lepidoptera, Nepticulidae

Stigmella lapponica - Lepidoptera, Nepticulidae

Stigmella latifasciella - Lepidoptera, Nepticulidae

Stigmella lemniscella - Lepidoptera, Nepticulidae

Stigmella malella- Lepidoptera, Nepticulidae: Banded apple pigmy

Stigmella mespilicola - Lepidoptera, Nepticulidae

Stigmella microtheriella - Lepidoptera, Nepticulidae

Stigmella minusculella - Lepidoptera, Nepticulidae

Stigmella myrtillella - Lepidoptera, Nepticulidae

Stigmella obliquella - Lepidoptera, Nepticulidae

Stigmella oxyacanthella - Lepidoptera, Nepticulidae

Stigmella paradoxa - Lepidoptera, Nepticulidae

Stigmella perpygmaeella - Lepidoptera, Nepticulidae 
Stigmella plagicolella - Lepidoptera, Nepticulidae

Stigmella pomivorella - Lepidoptera, Nepticulidae

Stigmella pretiosa - Lepidoptera, Nepticulidae

Stigmella prunetorum - Lepidoptera, Nepticulidae

Stigmella regiella - Lepidoptera, Nepticulidae

Stigmella rhamnella - Lepidoptera, Nepticulidae

Stigmella ruficapitella - Lepidoptera, Nepticulidae

Stigmella salicis - Lepidoptera, Nepticulidae

Stigmella samiatella - Lepidoptera, Nepticulidae

Stigmella sanguisorbae - Lepidoptera, Nepticulidae

Stigmella slingerlandella - Lepidoptera, Nepticulidae

Stigmella sorbi - Lepidoptera, Nepticulidae

Stigmella speciosa - Lepidoptera, Nepticulidae

Stigmella splendidissimella - Lepidoptera, Nepticulidae

Stigmella suberivora - Lepidoptera, Nepticulidae

Stigmella tiliae - Lepidoptera, Nepticulidae

Stigmella tityrella - Lepidoptera, Nepticulidae

Stigmella trimaculella - Lepidoptera, Nepticulidae

Stigmella ulmarie - Lepidoptera, Nepticulidae

Stigmella ulmivora - Lepidoptera, Nepticulidae

Stigmella viminetcola - Lepidoptera, Nepticulidae

Sympiesis sericeicornis - Hymenoptera, Eulophidae

Taphrocerus schaefferi - Coleoptera, Buprestidae

Tischeria deciduas - Lepidoptera, Tischeriidae

Tischeria dodonaea - Lepidoptera, Tischeriidae

Tischeria ekebladella - Lepidoptera, Tischeriidae

Tischeria malifoliella - Lepidoptera, Tischeriidae: Apple leaf trumpet miner

Tischeria zelleriella - Lepidoptera, Tischeriidae

Tropicomyia styricicola - Diptera, Agromyzidae

Trypeta artemisiae - Diptera, Tephritidae

Zeiraphera griseana - Lepidoptera: Tortricidae: Dingy larch bell

Zeugophora flavicollis - Coleoptera, Megalopodidae

\section{Neochrysocharis}

Hosts:

Acalyptris loranthella - Lepidoptera, Nepticulidae

Acantholyda erythrocephala - Hymenoptera, Pamphiliidae: Pine false webworm Acantholyda posticalis - Hymenoptera, Pamphiliidae

Agromyza lucida - Diptera, Agromyzidae

Agromyza oryzae - Diptera, Agromyzidae: Rice leafminer, Japanese leaf miner or

Japanese rice leafminer

Agromyza parvicornis - Diptera, Agromyzidae: Corn blotch leafminer

Aleyrodes proletellus - Hemiptera, Aleyrodidae

Aporia crataegi - Lepidoptera, Pieridae: Black-veined white

Asphondylia conglomerate - Diptera, Cecidomyiidae

Atherigona naqvii - Diptera, Muscidae: Shoot fly 
Aulagromyza hendeliana - Diptera, Agromyzidae

Bactocera oleae- Diptera, Tephritidae: Olive fruit fly

Bedellia orchilella - Lepidoptera, Lyonetiidae: Sweetpotato leafminer

Bemisia tabaci-Hemiptera, Aleyrodidae: Tobacco whitefly or sweetpotato whitefly

Blastotere thuiella - Lepidoptera, Agyresthiidae

Bucculatrix crataegi - Lepidoptera, Bucculatrigidae

Bucculatrix thurberiella - Lepidoptera, Bucculatrigidae: Cotton leaf perforator

Caliroa cerasi - Hymenoptera, Tenthredinidae: Pear sawfly

Calycomyza solidaginis - Diptera, Agromyzidae

Cerodontha angulata - Diptera, Agromyzidae

Chromatomyia aprilina - Diptera, Agromyzidae

Chromatomyia fuscula - Diptera, Agromyzidae

Chromatomyia horticola - Diptera, Agromyzidae: Pea leafminer or garden pea leafminer

Chromatomyia syngenesiae - Diptera, Agromyzidae: Chrysanthemum leafminer

Coelaenomenodera elaeidis - Coleoptera, Chrysomelidae: Oil palm leafminer

Coelaenomenodera perrieri - Coleoptera, Chrysomelidae

Coleophora deauratella - Lepidoptera, Coleophoridae: Red clover pest

Coleophora gazelle - Lepidoptera, Coleophoridae

Coleophora laricella - Lepidoptera, Coleophoridae: Larch casebearer or larch leaf miner

Coleophora microspinella - Lepidoptera, Coleophoridae

Coleophora santolinella - Lepidoptera, Coleophoridae

Coleotechnites apicitripunctellus - Lepidoptera, Gelechiidae

Coleotechnites laricella - Lepidoptera, Gelechiidae

Coleotechnites milleri - Lepidoptera, Gelechiidae: Lodgepole needleminer

Coleotechnites thujaella - Lepidoptera, Gelechiidae: Brown arborvitae leafminer

Cotesia glomerata - Hymenoptera, Braconidae: Cabbage white butterfly parasite

Cotesia tibialis - Hymenoptera, Braconidae

Cotesia vestalis - Hymenoptera, Braconidae

Cystiphora schmidti - Diptera, Cecidomyiidae: Skeleton weed gall midge

Diglyphus intermedius - Hymenoptera, Braconidae

Diprion pini - Hymenoptera, Diprionidae

Diprion simile- Hymenoptera, Diprionidae: pine sawfly

Donacivola fullawayi - Lepidoptera, Elachistidae

Donacivola saccharella - Lepidoptera, Elachistidae

Ectoedemia albifasciella - Lepidoptera, Nepticulidae

Exoteleia pinifoliella - Lepidoptera, Gelechiidae: Pine needle miner

Fenusa pusilla - Hymenoptera, Tenthredinidae: Birch leafminer

Holocacista rivillei - Lepidoptera, Heliozelidae

Hydrellia griseola - Diptera, Ephydridae

Iseropus stercorator - Hymenoptera, Ichneumonidae

Leiopus nebulosus - Coleoptera, Cerambycidae

Leucoptera coffeella - Lepidoptera, Lyonetiidae: Coffee leafminer

Leucoptera malifoliella - Lepidoptera, Lyonetiidae: Pear leaf blister moth or pear leaf miner

Leucoptera sinuella - Lepidoptera, Lyonetiidae

Liriomyza huidobrensis - Diptera, Agromyzidae: Pea leafminer 
Liriomyza pictella - Diptera, Agromyzidae: Melon leafminer

Liriomyza pusilla - Diptera, Agromyzidae: Serpentine leafminer

Liriomyza sativae - Diptera, Agromyzidae: Vegetable leafminer

Liriomyza sorosis - Diptera, Agromyzidae

Liriomyza trifolii - Diptera, Agromyzidae: American serpentine leafminer

Lyonetia clerkella - Lepidoptera, Lyonetiidae: Apple leaf miner

Malacosoma disstria - Lepidoptera, Lasiocampidae: Forest tent caterpillar

Mantura floridana - Coleoptera; Chrysomelidae

Meromyza americana - Diptera, Chloropidae: Wheat stem maggot

Metopomyza scutellata - Diptera, Agromyzidae

Metriochroa latifoliella - Lepidoptera, Gracillariidae: Small olive leafminer

Neodiprion fulviceps - Hymenoptera, Diprionidae: Pine infesting sawflies

Neodiprion lecontei - Hymenoptera, Diprionidae: Redheaded pine sawfly

Neodiprion sertifer - Hymenoptera, Diprionidae: European pine sawfly

Greenhouse

Ophiomyia simplex - Diptera, Agromyzidae: Asparagus miner

Oscinella frit - Diptera, Chloropidae

Palaeocimbex quadrimaculata - Hymenoptera, Cimbicidae

Pamphilius signatus - Hymenoptera, Pamphiliidae

Parafomoria helianthemella - Lepidoptera, Nepticulidae

Pegomya hyoscyami - Diptera, Anthomyiidae: Spinach leafminer

Phyllocnistis citrella - Lepidoptera, Gracillariidae: Citrus leafminer

Phyllonorycter blancardella- Lepidoptera, Gracillariidae: Spotted tentiform leafminer

Phyllonorycter cavella - Lepidoptera, Gracillariidae

Phyllonorycter celtisella - Lepidoptera, Gracillariidae

Phyllonorycter corylifoliella - Lepidoptera, Gracillariidae: Hawthorn red midget moth

Phyllonorycter maestingella - Lepidoptera Gracillariidae

Phyllonorycter messaniella - Lepidoptera, Gracillariidae: Zellar's midget

Phyllonorycter millierella - Lepidoptera, Gracillariidae

Phyllonorycter platani - Lepidoptera, Gracillariidae

Phyllonorycter quinnata - Lepidoptera, Gracillariidae

Phyllonorycter roboris - Lepidoptera, Gracillariidae

Phyllonorycter spinicolella - Lepidoptera, Gracillariidae

Phyllonorycter tenerella - Lepidoptera, Gracillariidae

Phyllotreta aeneicollis - Coleoptera, Chrysomelidae

Phytagromyza dianthicola - Diptera, Agromyzidae

Phytomyza angelicastri - Diptera, Agromyzidae

Phytomyza aquilegiae - Diptera, Agromyzidae

Phytomyza heringiana - Diptera, Agromyzidae

Phytomyza minuscule - Diptera, Agromyzidae

Phytomyza pubicornis - Diptera, Agromyzidae

Pococera robustella - Lepidoptera, Pyralidae: Pine webworm

Poemyza lateralis - Diptera, Agromyzidae

Pseudonapomyza spicata - Diptera, Agromyzidae: Maize leafminer

Pulvinaria maxima - Hemiptera, Coccidae

Rynchaenus fagi-Coleoptera, Curculionidae 
Rynchaenus quercus - Coleoptera, Curculionidae: Oak flea weevil Taphrocerus gracilis - Coleoptera, Buprestidae

Tetralicia erianthi - Hemiptera, Aleyrodidae

Therioaphis trifolii - Hemiptera, Aphididae: Spotted alfalfa aphid

Tischeria ekebladella - Lepidoptera, Tischeriidae

Trichogramma embryophagum - Hymenoptera, Trichogrammatidae

Trichogramma evanescens - Hymenoptera, Trichogrammatidae

Trifurcula thymi - Lepidoptera, Nepticulidae

Schizocerella pilicornis - Hymenoptera, Argidae: Portulaca sawfly

Stigmella caradjai - Lepidoptera, Nepticulidae

Stigmella carpinella - Lepidoptera, Nepticulidae

Stigmella centifoliella - Lepidoptera, Nepticulidae

Stigmella crataegella - Lepidoptera, Nepticulidae

Stigmella hahniella - Lepidoptera, Nepticulidae

Stigmella hybnerella - Lepidoptera, Nepticulidae

Stigmella incognitella - Lepidoptera, Nepticulidae

Stigmella malella - Lepidoptera, Nepticulidae: Banded apple pigmy

Stigmella nylandriella - Lepidoptera, Nepticulidae

Stigmella oxyacanthella - Lepidoptera, Nepticulidae

Stigmella pyri - Lepidoptera, Nepticulidae

Stigmella roborella - Lepidoptera, Nepticulidae

Stigmella ruficapitella - Lepidoptera, Nepticulidae

Stigmella thuringiaca - Lepidoptera, Nepticulidae

\section{Horismenus}

Host:

Acanthoscelides floridae - Coleoptera, Bruchidae

Acanthoscelides obtectus - Coleoptera, Bruchidae: Dry bean weevil

Acanthoscelides pallidipennis - Coleoptera, Bruchidae

Acanthoscelides spinipes - Coleoptera, Chrysomelidae

Acanthoscelides submuticus - Coleoptera, Chrysomelidae

Acleris minuta - Lepidoptera, Tortricidae: Yellowheaded fireworm

Acrobasis caryivorella - Lepidoptera, Pyralidae

Acrobasis rubrifasciella - Lepidoptera, Pyralidae

Alabama argillacea - Lepidoptera, Noctuidae: Cotton leafworm

Algarobius prosopis - Coleoptera, Bruchidae

Alurnus humeralis - Coleoptera, Chrysomelidae

Amblycerus robiniae - Coleoptera, Chrysomelidae

Amblycerus submaculatus - Coleoptera, Chrysomelidae

Ancylis comptana - Lepidoptera, Tortricidae: Strawberry leafroller

Ancylis nubeculana - Lepidoptera, Tortricidae

Andricus quercusflocci - Hymenoptera, Cynipidae

Apanteles diatraeae - Hymenoptera, Braconidae

Apanteles fumiferanae - Hymenoptera, Braconidae

Apanteles leucostigmus - Hymenoptera, Braconidae

Apanteles opsiphanis - Hymenoptera, Braconidae 
Apechthis bazani - Hymenoptera, Ichneumonidae

Aphidius colemani - Hymenoptera, Braconidae

Apion decoloratum - Coleoptera, Brentidae

Apion seniculus - Coleoptera, Brentidae

Bedellia somnulentella -Lepidoptera, Lyonetiidae: Sweet potato leafminer

Bracon cajani - Hymenoptera, Braconidae

Bracon thurberiphagae - Hymenoptera, Braconidae

Cameraria caryaefoliella - Lepidoptera, Gracillariidae

Cameraria cincinnatiella - Lepidoptera, Gracillariidae: Gregarious oak leafminer

Catocephala amphinome - Lepidoptera, Saturniidae

Catolaccus aeneoviridis - Hymenoptera, Pteromalidae

Ceratomia catalpae - Lepidoptera, Sphingidae: Catalpa sphinx

Ceroplastes novaesi - Hemiptera, Coccidae

Choreutis pariana - Lepidoptera, Choreutidae: Apple leaf skeletonizer

Choristoneura rosaceana - Lepidoptera, Tortricidae: Obliquebanded leafroller

Chrysobothris femorata - Coleoptera, Buprestidae: Flatheaded appletree borer

Chrysopa alobana - Neuroptera, Chrysopidae

Chrysopa arioles - Neuroptera, Chrysopidae

Chrysopa claveri - Neuroptera, Chrysopidae

Chrysopa cubana - Neuroptera, Chrysopidae

Chrysopa iona - Neuroptera, Chrysopidae

Chrysopa lateralis - Neuroptera, Chrysopidae

Chrysopa sanchezi - Neuroptera, Chrysopidae

Coleophora laricella - Lepidoptera, Coleophoridae: Larch casebearer or larch leaf miner

Coleophora malivorella - Lepidoptera, Coleophoridae: Pistol case bearer

Coleophora pruniella - Lepidoptera, Coleophoridae

Cotesia americana - Hymenoptera, Braconidae

Cotesia congregate - Hymenoptera, Braconidae

Cotesia glomerata - Hymenoptera, Braconidae: Cabbage white butterfly parasite

Cotesia melanoscela - Hymenoptera, Braconidae

Cotesia pyraustae - Hymenoptera, Braconidae

Cotesia schizurae - Hymenoptera, Braconidae

Cryptothelea gloverii - Lepidoptera, Psychidae: Orange bagworm

Cylindrocopturus adspersus - Coleoptera, Curculionidae: Sunflower stem weevil

Diaprepes abbreviatus - Coleoptera, Curculionidae: Diaprepes root weevil

Diaprepes famelicus - Coleoptera, Curculionidae

Dichomeris marginella - Lepidoptera, Gelechiidae: Juniper webworm

Dolichogenidea paralechiae - Hymenoptera, Braconidae

Eacles imperialis - Lepidoptera, Saturniidae: Imperial moth

Elasmopalpus lignosellus - Lepidoptera, Pyralidae

Eulechriops manihoti - Coleoptera, Curculionidae

Eumetopiella rufipes - Diptera, Otitidae

Euplectrus comstockii - Hymenoptera, Eulophidae

Euplectrus platyhypenae - Hymenoptera, Eulophidae

Euplectrus puttleri - Hymenoptera, Eulophidae

Exoteleia pinifoliella - Lepidoptera, Gelechiidae: Pine needle miner 
Geina periscelidactyla - Lepidoptera, Pterophoridae: Plume moth

Glyptapanteles concinnus - Hymenoptera, Braconidae

Hemisphaerota cyanea - Coleoptera, Chrysomelidae: Tortoise beetle or Florida tortoise beetle

Homaledra sabalella - Lepidoptera, Coleophoridae: Palm leaf skeletonizer

Iconella etiellae - Hymenoptera, Braconidae

Lethata anophthalma - Lepidoptera, Oecophoridae

Leucania latiuscula - Lepidoptera, Noctuidae

Leucochrysa varia - Neuroptera, Chrysopidae

Leucoma salicis - Lepidoptera, Lyonetiidae: Satin Moth

Leucoptera albella - Lepidoptera, Lyonetiidae

Leucoptera coffeella - Lepidoptera, Lyonetiidae: Coffee leafminer

Lixus musculus - Coleoptera, Curculionidae

Lixus perforatus - Coleoptera, Curculionidae

Lixus scrobicollis - Coleoptera, Curculionidae

Macromphalia dedecora - Lepidoptera, Lasiocampidae

Mantispa decorate - Neuroptera, Mantispidae

Mayetiola destructor - Diptera, Cecidomyiidae: Hessian fly

Megalopyge urens - Lepidoptera, Megalopygidae

Meromyza americana - Diptera, Chloropidae: Wheat stem maggot

Metagonistylum minense - Diptera, Tachinidae

Meteorus deltae - Hymenoptera, Braconidae

Microplitis ceratomiae - Hymenoptera, Braconidae

Mimosestes amicus - Coleoptera, Bruchidae

Mimosestes nubigens - Coleoptera, Bruchidae: Bean weevil

Neocryptopteryx orientalis - Hymenoptera, Ichneumonidae

Nola sorghiella - Lepidoptera, Nolidae: Sorghum webworm

Oncideres singulata - Coleoptera, Cerambycidae

Oncophanes americanus - Hymenoptera, Braconidae

Opsiphanes cassiae - Lepidoptera, Nymphalidae

Orgyia leucostigma - Lepidoptera, Lymantriidae: White-marked tussock moth

Paratheresia brasiliensis - Diptera, Tachinidae

Parornix geminatella - Lepidoptera, Gracillariidae: Unspotted tentiform leafminer

Parthenoleskia parkeri - Diptera, Tachinidae

Pectinophora gossypiella - Lepidoptera, Gelechiidae: Pink bollworm

Phobetron hipparchia - Lepidoptera, Limacodidae

Phelomerus lineola - Coleoptera, Bruchidae

Pholetesor ornigis - Hymenoptera, Braconidae

Phyllocnistis citrella- Lepidoptera, Gracillariidae: Citrus leafminer

Phyllocnistis populiella - Lepidoptera, Gracillariidae: Aspen serpentine leafminer or

Aspen leafminer

Phyllonorycter crataegella - Lepidoptera Gracillariidae: apple blotch leafminer

Phyllonorycter propinquinella - Lepidoptera, Gracillariidae: cherry blotchminer

Physonota alutacea - Coleoptera, Chrysomelidae: Wild olive tortoise beetle

Pococera robustella - Lepidoptera, Pyralidae: Pine webworm

Pococera subcanalis - Lepidoptera, Pyralidae 
Psephenus texanus - Coleoptera, Psephenidae

Pseudogaurax signatus - Diptera, Chloropidae

Quadrastichus haitiensis - Hymenoptera, Eulophidae

Saucrobotys futilalis - Lepidoptera, Pyralidae: Panic moth

Scrobipalpa absoluta - Lepidoptera, Gelechiidae

Sennius bondarus - Coleoptera, Chrysomelidae

Stator pruininus - Coleoptera, Bruchidae

Steirastoma breve - Coleoptera, Cerambycidae: Cocoa beetle

Steirastoma depressum - Coleoptera, Cerambycidae

Sympiesis marylandensis - Hymenoptera, Eulophidae

Sympiesis sericeicornis - Hymenoptera, Eulophidae

Tanaostigmodes haematoxyli - Hymenoptera, Tanaostigmatidae

Taphrocerus cocois - Coleoptera, Buprestidae

Tetramesa adrianae - Hymenoptera, Eurytomidae

Thyridopteryx ephemeraeformis - Lepidoptera, Psychidae: Bagworm moth

Tischeria malifoliella - Lepidoptera, Tischeriidae: Apple leaf trumpet miner

Urbanus proteus - Lepidoptera, Hesperiidae: Long-tailed skipper

\section{Omphale}

Host:

Chromatomyia horticola - Diptera, Agromyzidae: Pea leafminer or garden pea leafminer

Chromatomyia syngenesiae - Diptera, Agromyzidae: Chrysanthemum leafminer

Contarinia lentis - Diptera, Cecidomyiidae

Contarinia medicaginis - Diptera, Cecidomyiidae: Lucerne flower midge

Cystiphora - Diptera, Cecidomyiidae

Dasineura brassicae - Diptera, Cecidomyiidae: Brassica pod midge

Dasineura oxycoccana - Diptera, Cecidomyiidae: Blueberry gall midge

Eulecanium coryli - Hemiptera, Coccidae

Geocrypta - Diptera, Cecidomyiidae: Gall midges

Henosepilachna vigintioctopunctata - Coleoptera, Coccinellidae: Twentysix-spotted potato ladybird

Lasioptera - Diptera, Cecidomyiidae

Leucoptera malifoliella - Lepidoptera, Lyonetiidae: Pear leaf blister moth or pear leaf miner

Liriomyza sativae - Diptera, Agromyzidae: Vegetable leafminer

Macrolabis - Diptera, Cecidomyiidae: gall midges

Mikiola fagi - Diptera, Cecidomyiidae: gall midges

Mycodiplosis - Diptera, Cecidomyiidae: gall midges

Natada nararia - Lepidoptera, Limacodidae: Nettle grub, fringed nettle grub or slug caterpillar

Odontota dorsalis - Coleoptera, Chrysomelidae: Locust leafminer

Phyllonorycter messanella - Lepidoptera, Gracillariidae: Zellar's midget 


\section{Pediobius}

Host:

Achrysocharoides albiscapus - Hymenoptera, Eulophidae

Achrysocharoides splendens - Hymenoptera, Eulophidae

Acracona remipedalis - Lepidoptera, Pyralidae

Acrobasis comptoniella - Lepidoptera, Pyralidae: Sweetfern leaf casebearer

Acrocercops astaurota - Lepidoptera, Gracillariidae

Adleria coriaria - Hymenoptera, Cynipidae

Adoxophyes orana - Lepidoptera, Tortricidae: Summerfruit tortrix

Adoxophyes privatana - Lepidoptera, Tortricidae: Appleleaf-curling moth

Agasthenes varitarsus - Hymenoptera, Ichneumonidae

Ageniaspis testaceipes - Hymenoptera, Encyrtidae

Agonopterix nervosa - Lepidoptera, Oecophoridae: Gorse tip moth

Agrapha agnate - Lepidoptera, Noctuidae

Agrapha albostriata - Lepidoptera, Noctuidae

Agromyza nana - Diptera, Agromyzidae

Agromyza parvicornis - Diptera, Agromyzidae: Corn blotch leafminer

Agromyza salicifolii - Diptera, Agromyzidae

Aleiodes gastritor - Hymenoptera, Braconidae

Aleiodes pallidator - Hymenoptera, Braconidae

Aleiodes stigmator - Hymenoptera, Braconidae

Amauromyza flavifrons - Diptera, Agromyzidae

Amauromyza verbasci - Diptera, Agromyzidae

Amphibolips quercusinanis - Hymenoptera, Cynipidae

Amphibolips quercusspongifica - Hymenoptera, Cynipidae

Ancylis comptana - Lepidoptera, Tortricidae: Strawberry leafroller

Ancylis mitterbacheriana - Lepidoptera, Tortricidae

Ancylis upupana - Lepidoptera, Tortricidae

Ancyloxypha numitor - Lepidoptera, Hesperiidae: Least skipper

Andricus burgundus - Hymenoptera, Cynipidae

Andricus curvator - Hymenoptera, Cynipidae

Andricus grossulariae - Hymenoptera, Cynipidae

Andricus testaceipes - Hymenoptera, Cynipidae

Anomis leona - Lepidoptera, Noctuidae

Antestia intricate - Hemiptera, Pentatomidae

Antestiopsis orbitalis - Hemiptera, Pentatomidae

Anthonomus nigrinus - Coleoptera, Curculionidae

Anthophora abrupta - Hymenoptera, Anthophoridae

Antispila anna - Lepidoptera, Gracillariidae: Jamun leaf miner

Apanteles agilis - Hymenoptera, Braconidae

Apanteles bordagei - Hymenoptera, Braconidae

Apanteles congoensis - Hymenoptera, Braconidae

Apanteles kuwayamai - Hymenoptera, Braconidae

Apanteles pelops - Hymenoptera, Braconidae

Apanteles sagax - Hymenoptera, Braconidae

Apanteles syleptae - Hymenoptera, Braconidae 
Apanteles taragamae - Hymenoptera, Braconidae

Apanteles transvaalensis - Hymenoptera, Braconidae

Apechthis rufata - Hymenoptera, Ichneumonidae

Aporia crataegi - Lepidoptera, Pieridae: Black-veined white

Apotomis lutosana - Lepidoptera, Tortricidae

Archips crataegana - Lepidoptera, Tortricidae: Brown oak tortrix

Archips occidentalis - Lepidoptera, Tortricidae

Archips rosana - Lepidoptera, Tortricidae: European leafroller or rose tortrix moth

Archips xylosteana - Lepidoptera, Tortricidae: Brown oak tortrix or variegated golden

tortrix

Artona catoxantha - Lepidoptera, Zygaenidae: Coconut leaf moth, coconut leaf skeletonizer, Malayan coconut zygaenid, or Malayan coconut moth

Aspidimorpha maculatissima - Coleoptera, Chrysomelidae

Aspidimorpha puncticostosa - Coleoptera, Chrysomelidae

Aspidimorpha quadrimaculata - Coleoptera, Chrysomelidae

Aulagromyza hendeliana - Diptera, Agromyzidae

Aulagromyza populi - Diptera, Agromyzidae

Aulagromyza populicola - Diptera, Agromyzidae

Aulagromyza tridentate - Diptera, Agromyzidae

Baryscapus evonymellae - Hymenoptera, Eulophidae

Belonogaster juncea - Hymenoptera, Vespidae

Bessa remota - Diptera, Tachinidae

Biorhiza pallida - Hymenoptera, Cynipidae: Oak apple gall wasp

Blastotere thuiella - Lepidoptera, Agyresthiidae

Blepharipa zebina - Diptera, Tachinidae: Uzi fly

Bombus americanorum - Hymenoptera, Apidae: American bumblebee

Bombus atratus - Hymenoptera, Apidae

Borbo gemella - Lepidoptera, Hesperiidae

Brachymeria euploeae - Hymenoptera, Chalcididae

Bracon brevicornis - Hymenoptera, Braconidae

Bracon gelechiae - Hymenoptera, Braconidae

Bracon pectoralis - Hymenoptera, Braconidae

Bracon politiventris - Hymenoptera, Braconidae

Bracon variegator - Hymenoptera, Braconidae

Bracon xanthonotus - Hymenoptera, Braconidae

Bucculatrix adelpha - Lepidoptera, Bucculatrigidae

Bucculatrix canadensisella - Lepidoptera, Bucculatrigidae: Birch skeletonizer

Bucculatrix crataegi - Lepidoptera, Bucculatrigidae

Bucculatrix ulmella - Lepidoptera, Bucculatrigidae

Busseola fusca - Lepidoptera, Noctuidae: African maize stalk borer

Busseola segeta - Lepidoptera, Noctuidae

Cacoecimorpha pronubana - Lepidoptera, Tortricidae: Carnation tortrix

Calopepla leayana - Coleoptera, Chrysomelidae

Caloptilia negundella - Lepidoptera, Gracillariidae: Boxelder leafroller

Caloptilia roscipennella - Lepidoptera, Gracillariidae

Caloptilia ulmi - Lepidoptera, Gracillariidae 
Calycomyza jucunda - Diptera, Agromyzidae

Cameraria aceriella - Lepidoptera, Gracillariidae: Maple leafblotch miner

Cameraria corylisella - Lepidoptera, Gracillariidae

Cameraria guttifinitella - Lepidoptera, Gracillariidae

Cameraria hamadryadella - Lepidoptera, Gracillariidae: Solitary oak leafminer

Campoplex homonae - Hymenoptera, Ichneumonidae

Carcelia modicella - Diptera, Tachinidae

Casinaria limenitidis - Hymenoptera, Ichneumonidae

Cassida deflorata - Coleoptera, Chrysomelidae

Cassida viridis - Coleoptera, Chrysomelidae

Cedria paradoxa - Hymenoptera, Braconidae

Cerodontha angulata - Diptera, Agromyzidae

Cerodontha incise - Diptera, Agromyzidae

Cerodontha pygmaea - Diptera, Agromyzidae

Cephus cinctus - Hymenoptera, Cephidae: Wheat stem sawfly

Cephus infuscatus - Hymenoptera, Cephidae

Cephus pygmaeus - Hymenoptera, Cephidae: Corn sawfly

Chilaspis nitida - Hymenoptera, Cynipidae

Chilo indicus - Lepidoptera, Pyralidae: Sugarcane internode borer

Chilo orichalcociliellus - Lepidoptera, Pyralidae

Chilo partellus - Lepidoptera, Pyralidae: Sugarcane stalk borer

Choreutis nemorana - Lepidoptera, Choreutidae

Choristoneura diversana - Lepidoptera, Tortricidae

Choristoneura fumiferana - Lepidoptera, Tortricidae: Spruce budworm

Choristoneura hebenstreitella - Lepidoptera, Tortricidae

Choristoneura murinana - Lepidoptera, Tortricidae: European fir budworm

Choristoneura rosaceana - Lepidoptera, Tortricidae: Obliquebanded leafroller

Chromatomyia aprilina - Diptera, Agromyzidae

Chromatomyia fuscula - Diptera, Agromyzidae

Chromatomyia horticola - Diptera, Agromyzidae: Pea leafminer or garden pea leafminer

Chromatomyia milii - Diptera, Agromyzidae

Chromatomyia periclymeni - Diptera, Agromyzidae

Chromatomyia primulae - Diptera, Agromyzidae

Chromatomyia syngenesiae - Diptera, Agromyzidae: Chrysanthemum leafminer

Chrysocharis nepherea - Hymenoptera, Eulophidae

Chrysocharis pubicornis - Hymenoptera, Eulophidae

Cirrospilus cinctiventris - Hymenoptera, Eulophidae

Cirrospilus variegates - Hymenoptera, Eulophidae

Clanoneurum menozzii - Diptera, Ephydridae

Clostera anachoreta - Lepidoptera, Notodontidae: Scarce chocolate-tip

Clostera anastomosis - Lepidoptera, Notodontidae

Clostera cupreata - Lepidoptera, Notodontidae

Cnaphalocrocis medinalis - Lepidoptera, Pyralidae: Rice leaf roller

Cnaphalocrocis trapezalis - Lepidoptera, Pyralidae

Coccinella septempunctata - Coleoptera, Coccinellidae: Sevenepotted lady beetle

Coelaenomenodera elaeidis - Coleoptera, Chrysomelidae: Oil palm leafminer 
Colpoclypeus florus - Hymenoptera, Eulophidae

Compsilura concinnata - Diptera, Tachinidae

Coniesta ignefusalis - Lepidoptera, Pyralidae: Millet stem borer

Contarinia sorghicola - Diptera, Cecidomyiidae: Sorghum midge

Conura meteori - Hymenoptera, Chalcididae

Cornicacoecia lafauryana - Lepidoptera, Tortricidae

Cotesia clisiocampae - Hymenoptera, Braconidae

Cotesia congregate - Hymenoptera, Braconidae

Cotesia erionotae - Hymenoptera, Braconidae

Cotesia glomerata - Hymenoptera, Braconidae: Cabbage white butterfly parasite

Cotesia hyphantriae - Hymenoptera, Braconidae

Cotesia melanoscela - Hymenoptera, Braconidae

Cotesia ruficrus - Hymenoptera, Braconidae

Cotesia sesamiae - Hymenoptera, Braconidae

Cremastopsyche pendula - Lepidoptera, Psychidae: Coconut bagworm

Cricula trifenestrata - Lepidoptera, Saturniidae

Crioceris merdigera - Coleoptera, Chrysomelidae: European beetle

Crocidophora pustuliferalis - Lepidoptera, Pyralidae

Cyclogastrella simplex - Hymenoptera, Pteromalidae

Cydia critica - Lepidoptera, Tortricidae: Leaf webber

Cydia leucostoma - Lepidoptera, Tortricidae: Flushworm

Cynips longiventris - Hymenoptera, Cynipidae

Cyrtogaster vulgaris - Hymenoptera, Pteromalidae

Dactylispa melanaria - Coleoptera, Chrysomelidae

Dendroleon jezoensis - Neuroptera, Myrmeleontidae

Diacrisia punctulata - Lepidoptera, Arctiidae

Diadegma armillatum - Hymenoptera, Ichneumonidae

Diadegma trochanteratum - Hymenoptera, Ichneumonidae

Diatraea dyari - Lepidoptera, Pyralidae: Cane borer

Diatraea grandiosella - Lepidoptera, Pyralidae: Southwestern corn borer

Diatraea lineolata - Lepidoptera, Pyralidae: Neotropical corn borer

Diatraea rufescens - Lepidoptera, Pyralidae

Diatraea saccharalis - Lepidoptera, Pyralidae: Sugarcane borer

Dibrachoides dynastes - Hymenoptera, Pteromalidae

Dibrachys cavus - Hymenoptera, Pteromalidae

Dimmockia incongrua - Hymenoptera, Eulophidae

Dimmockia pallipes - Hymenoptera, Eulophidae

Dinotiscus colon - Hymenoptera, Pteromalidae

Diopsis ichneumonea - Diptera, Diopsidae: Telescope fly

Diopsis macrophthalma - Diptera, Diopsidae: Stalk-eyed fly

Dioryctria amatella - Lepidoptera, Pyralidae: Southern pine coneworm

Dioryctria splendidella - Lepidoptera, Pyralidae: Pine stem borer or Maritime pine stem borer

Cerodontha iraeos - Diptera, Agromyzidae

Cerodontha iridis - Diptera, Agromyzidae

Dolichogenidea aethiopica - Hymenoptera, Braconidae 
Dolichogenidea albipennis - Hymenoptera, Braconidae

Dolichogenidea lacteicolor - Hymenoptera, Braconidae

Dolichogenidea metesae - Hymenoptera, Braconidae

Eccopsis wahlbergiana - Lepidoptera, Tortricidae

Elachista nigrella - Lepidoptera, Elachistidae

Elasmus brevicornis - Hymenoptera, Eulophidae

Elasmus flabellatus - Hymenoptera, Eulophidae

Elasmus leucopterae - Hymenoptera, Eulophidae

Elasmus philippinensis - Hymenoptera, Eulophidae

Ellipsidion australe - Blattodea, Blatellidae

Ellipsidion pellucidum - Blattodea, Blatellidae

Endelus bakeri - Coleoptera, Buprestidae

Endothenia gentianaeana - Lepidoptera, Tortricidae

Endromopoda arundinator - Hymenoptera, Ichneumonidae

Enteucha acetosae - Lepidoptera, Nepticulidae

Enytus apostate - Hymenoptera, Ichneumonidae

Eoreuma loftini - Lepidoptera, Pyralidae: Mexican rice borer

Epiblema strenuana - Lepidoptera, Tortricidae: Parthenium stemgalling moth

Epicephala chalybacma - Lepidoptera, Gracillariidae

Epilachna chrysomelina - Coleoptera, Coccinellidae: Twelve-spotted melon beettle

Epilachna dodecastigma - Coleoptera, Coccinellidae: Epilachna beetle

Epilachna mexicana - Coleoptera, Coccinellidae

Epilachna obscurella - Coleoptera, Coccinellidae

Epilachna ocellata - Coleoptera, Coccinellidae

Epilachna philippinensis - Coleoptera, Coccinelidae: 28 spotted ladybird beetle or

Phillipine ladybird beetle

Epilachna similis - Coleoptera, Coccinellidae

Epilachna tredecimnotata - Coleoptera, Coccinellidae

Epilachna varivesis - Coleoptera, Coccinelidae

Epiphora bauhiniae - Lepidoptera, Saturniidae

Eriocrania sparrmannella - Lepidoptera, Eriocraniidae

Eriogaster lanestris - Lepidoptera, Lasiocampidae

Erionota thrax - Lepidoptera, Hesperiidae: Banana leafroller, banana skipper, palm redeye

Eubazus minutus - Hymenoptera, Braconidae

Eublemma gayneri - Lepidoptera, Noctuidae

Eudocima fullonia - Lepidoptera, Noctuidae: Fruitpiercing moth

Eulophus basalis - Hymenoptera, Eulophidae

Eulophus brevicapitatus - Hymenoptera, Eulophidae

Eulophus larvarum - Hymenoptera, Eulophidae

Eupelmus annulatus - Hymenoptera, Eupelmidae

Eupelmus vesicularis - Hymenoptera, Eupelmidae

Eupithecia tripunctaria - Lepidoptera, Geometridae: White-spotted pug

Euplectromorpha bicarinata - Hymenoptera, Eulophidae

Euplectrus bicolor - Hymenoptera, Eulophidae

Euplectrus fukaii - Hymenoptera, Eulophidae 
Euplectrus leonae - Hymenoptera, Eulophidae

Euproctis chrysorrhoea - Lepidoptera, Lymantriidae: Brown-tail moth

Euproctis phaeorrhoea - Lepidoptera, Lymantriidae

Eurytoma appendigaster - Hymenoptera, Eurytomidae

Eurytoma collaris - Hymenoptera, Eurytomidae

Eurytoma noxialis - Hymenoptera, Eurytomidae

Eurytoma phalaridis - Hymenoptera, Eurytomidae

Eurytoma pollux - Hymenoptera, Eurytomidae

Eurytoma verticillata - Hymenoptera, Eurytomidae

Exophthalmus vitticollis - Coleoptera, Curculionidae

Exorista fasciata - Diptera, Tachinidae

Exorista sorbillans - Diptera, Tachinidae

Galerucella grisescens - Coleoptera, Chrysomelidae

Galerucella nymphaeae - Coleoptera, Chrysomelidae: Water lily leaf beetle

Galleria mellonella - Lepidoptera, Pyralidae: Greater wax moth

Gambrus extrematis - Hymenoptera, Ichneumonidae

Geina periscelidactyla - Lepidoptera, Pterophoridae: Plume moth

Gelis tenellus - Hymenoptera, Ichnuemonidae

Geshna cannalis - Lepidoptera, Pyralidae: Lesser canna leafroller

Glyptapanteles artonae - Hymenoptera, Braconidae

Glyptapanteles fulvipes - Hymenoptera, Braconidae

Glyptapanteles liparidis - Hymenoptera, Braconidae

Glyptapanteles porthetriae - Hymenoptera, Braconidae

Gnorimoschema gallaesolidaginis - Lepidoptera, Gelechiidae: Goldenrod elliptical-gall moth or goldenrod gall moth

Gnorimoschema salinaris - Lepidoptera, Gelechiidae

Goniozus japonicus - Hymenoptera, Bethylidae

Gonophora taylori - Coleoptera, Chrysomelidae

Gonophora xanthomelana - Coleoptera, Chrysomelidae

Grapholita molesta - Lepidoptera, Tortricidae: Oriental fruit moth

Gynaikothrips ficorum - Thysanoptera, Phlaeothripidae: Cuban laurel thrips

Haritalodes derogata - Lepidoptera, Pyralidae: Cotton leaf roller

Helcystogramma macroscopum - Lepidoptera, Gelechiidae

Helicoverpa armigera - Lepidoptera, Noctuidae: Corn ear worm, tomato grub, tobacco

bidworm, cotton bollworm

Henosepilachna vigintioctomaculata - Coleoptera, Coccinellidae

Henosepilachna vigintioctopunctata - Coleoptera, Coccinellidae: Twentysix-spotted potato ladybird

Heteronygmia dissimilis - Lepidoptera, Lymantriidae: African Mahogany-feeding

Caterpillar or Mahogony defoliator

Holocacista rivillei - Lepidoptera, Heliozelidae

Hyalophora cecropia - Lepidoptera, Saturniidae: Cecropia moth

Hydrellia griseola - Diptera, Ephydridae

Hylesinus crenatus - Coleoptera, Scolytidae: Larch elm bark beetle

Hyphantria cunea - Lepidoptera, Arctiidae: Fall webworm moth

Hyposoter fugitives - Hymenoptera, Ichneumonidae 
Illiberis pruni - Lepidoptera, Zygaenidae: Pear leaf worm or pear spotted caterpillar Iseropus coelebs - Hymenoptera, Ichneumonidae Itoplectis alternans - Hymenoptera, Ichneumonidae Itoplectis conquisitor - Hymenoptera, Ichneumonidae Itoplectis cristatae - Hymenoptera, Ichneumonidae Laothoe juglandisn - Lepidoptera, Sphingidae: Walnut sphinx Levarchama eurema - Lepidoptera, Nepticulidae Leiopus nebulosus - Coleoptera, Cerambycidae Lema honorata - Coleoptera, Chrysomelidae: Red thorax leaf bug Leucoma salicis - Lepidoptera, Lyonetiidae: Satin Moth Leucoptera caffeina - Lepidoptera, Lyonetiidae: Coffee leafminer Leucoptera coffeella - Lepidoptera, Lyonetiidae: Coffee leafminer Leucoptera coma - Lepidoptera, Lyonetiidae Leucoptera laburnella - Lepidoptera, Lyonetiidae: Laburnum leaf miner

Leucoptera malifoliella - Lepidoptera, Lyonetiidae: Pear leaf blister moth or pear leaf miner

Leucoptera meyricki - Lepidoptera, Lyonetiidae: Coffee leafminer

Leucoptera sinuella - Lepidoptera, Lyonetiidae

Liriomyza bryoniae - Diptera, Agromyzidae: Celery miner

Liriomyza huidobrensis - Diptera, Agromyzidae: Pea leafminer

Liriomyza pusilla - Diptera, Agromyzidae: Serpentine leafminer

Liriomyza strigata - Diptera, Agromyzidae

Lissonota sapinea - Hymenoptera, Ichneumonidae

Lobesia cunninghamiacola - Lepidoptera, Tortricidae

Lochmaeus manteo - Lepidoptera, Notodontidae: Variable oak leaf caterpillar

Lonchaea cortices - Diptera, Lonchaeidae

Lymantria dispar - Lepidoptera, Lymantriidae: Gypsy Moth

Macrocentrus linearis - Hymenoptera, Braconidae

Macrocentrus resinellae - Hymenoptera, Braconidae

Macrosiphum euphorbiae - Hemiptera, Aphidiidae: Potato aphid

Mada polluta - Coleoptera, Coccinellidae

Magdalis aenescens - Coleoptera, Curculionidae: Bronze appletree weevil

Mahasena corbetti - Lepidoptera, Psychidae: Coconut case caterpillar, Coconut bagworm or oilpalm bagworm

Malacosoma americanum - Lepidoptera, Lasiocampidae: Eastern tent caterpillar

Malata delphinae - Coleoptera, Coccinellidae

Marmara fasciella - Lepidoptera, Gracillariidae: White pine bark miner

Mastrus annulatus - Hymenoptera, Ichnuemonidae

Mastrus smithii - Hymenoptera, Ichnuemonidae

Mayetiola destructor - Diptera, Cecidomyiidae: Hessian fly

Mayetiola phalaris - Diptera, Cecidomyiidae

Mayetiola poae - Diptera, Cecidomyiidae

Melanitis constantia - Lepidoptera, Nymphalidae

Melanitis leda - Lepidoptera, Nymphalidae

Menochilus sexmaculatus - Coleoptera, Coccinellidae

Meteorus ictericus - Hymenoptera, Braconidae 
Meteorus indagator - Hymenoptera, Braconidae

Meteorus versicolor - Hymenoptera, Braconidae

Metopomyza scutellata - Diptera, Agromyzidae

Micraphe lateritia - Lepidoptera, Limacodidae

Microgaster meridiana - Hymenoptera, Braconidae

Micrurapteryx kollariella - Lepidoptera, Gracillariidae

Minotetrastichus frontalis - Hymenoptera, Eulophidae

Mniotype adustus - Lepidoptera, Noctuidae

Mompha epilobiella - Lepidoptera, Momphidae

Naranga aenescens - Lepidoptera, Noctuidae: Green semilooper

Nematus oligospilus - Hymenoptera, Tenthredinidae: Willow sawfly

Nemorilla floralis - Diptera, Tachinidae

Nephopterix leucophaeella - Lepidoptera, Pyralidae

Nephopterix rhodobasalis - Lepidoptera, Pyralidae

Neuroterus albipes - Hymenoptera, Cynipidae: Smooth spangle gall wasp

Neuroterus lanuginosus - Hymenoptera, Cynipidae

Neuroterus numismalis - Hymenoptera, Cynipidae

Neuroterus quercusbaccaru - Hymenoptera, Cynipidae

Neuroterus saliens - Hymenoptera, Cynipidae

Neuroterus saltans - Hymenoptera, Cynipidae

Niphadolepis alianta - Lepidoptera, Limacodidae

Notanisomorphella borborica - Hymenoptera, Eulophidae

Nyereria mlanje - Hymenoptera: Braconidae

Odites artigena - Lepidoptera, Lecithoceridae

Odontota dorsalis - Coleoptera, Chrysomelidae: Locust leafminer

Oecura goodie - Lepidoptera, Lymantriidae

Olethreutes ineptana - Lepidoptera, Tortricidae

Oncophanes americanus - Hymenoptera, Braconidae

Ophiomyia maura - Diptera, Agromyzidae

Ophiomyia simplex - Diptera, Agromyzidae: Asparagus miner

Opisina arenosella - Lepidoptera, Oecophoridae: Coconut black-headed caterpillar

Orgyia antique - Lepidoptera, Lymantriidae: Rusty tussock moth

Orgyia dubia - Lepidoptera, Lymantriidae

Orgyia leucostigma - Lepidoptera, Lymantriidae: White-marked tussock moth

Orgyia pseudotsugata - Lepidoptera, Lymantriidae: Douglas-fir tussock moth

Orgyia vetusta - Lepidoptera, Lymantriidae: Western tussock moth

Oscinella frit - Diptera, Chloropidae

Ostrinia nubilalis - Lepidoptera, Pyralidae: European corn borer

Pagodiella hekmeyeri - Lepidoptera, Psychidae

Palpita machaeralis - Lepidoptera, Pyralidae: Teak leaf eating caterpillar

Pandemis cerasana - Lepidoptera, Tortricidae: Barred fruit tree tortrix

Parafomoria helianthemella - Lepidoptera, Nepticulidae

Parapoynx stagnalis - Lepidoptera, Pyralidae: Rice caseworm

Parasa lepida - Lepidoptera, Limacodidae: Nettle caterpillar, blue-striped nettle grub, or green-striped nettle grub

Parnara guttata - Lepidoptera, Hesperiidae: Common straight swift 
Parornix anguliferella - Lepidoptera, Gracillariidae

Pectinophora gossypiella - Lepidoptera, Gelechiidae: Pink bollworm

Pediobius setigerus - Hymenoptetra, Eulophidae

Pegomya tenera - Diptera, Anthomyiidae

Pelopidas mathias - Lepidoptera, Hesperiidae: Small branded swift, lesser millet skipper, black branded swift

Perisierola nephantidis - Hymenoptera, Bethylidae

Petrova cristata - Lepidoptera, Tortricidae: Japanese pine shoot borer

Pexicopia malvella - Lepidoptera, Gelechiidae: Hollyhock seed moth

Phalaenoides glycine - Lepidoptera, Noctuidae: Grapevine moth

Phobocampe clisiocampae - Hymenoptera, Ichneumonidae

Pholetesor circumscriptus - Hymenoptera, Braconidae

Phycita diaphana - Lepidoptera, Pyralidae

Phyllocnistis citrella- Lepidoptera, Gracillariidae: Citrus leafminer

Phyllocnistis populiella - Lepidoptera, Gracillariidae: Aspen serpentine leafminer or Aspen leafminer

Phyllocnistis saligna - Lepidoptera, Gracillariidae

Phyllocnistis xenia - Lepidoptera, Gracillariidae

Phyllonorycter acerifoliella - Lepidoptera, Gracillariidae

Phyllonorycter basistrigella - Lepidoptera, Gracillariidae

Phyllonorycter bicinctella - Lepidoptera, Gracillariidae

Phyllonorycter blancardella - Lepidoptera, Gracillariidae: Spotted tentiform leafminer

Phyllonorycter cavella - Lepidoptera, Gracillariidae

Phyllonorycter comparella - Lepidoptera, Gracillariidae

Phyllonorycter coryli - Lepidoptera, Gracillariidae: Nut leaf blister moth

Phyllonorycter corylifoliella - Lepidoptera, Gracillariidae: Hawthorn red midget moth

Phyllonorycter delitella - Lepidoptera, Gracillariidae

Phyllonorycter distentella - Lepidoptera, Gracillariidae

Phyllonorycter issikii - Lepidoptera, Gracillariidae

Phyllonorycter kleemannella - Lepidoptera Gracillariidae

Phyllonorycter lautella - Lepidoptera, Gracillariidae

Phyllonorycter lucetiella - Lepidoptera Gracillariidae: Basswood squareblotch miner

Phyllonorycter maestingella - Lepidoptera Gracillariidae

Phyllonorycter malella - Lepidoptera, Gracillariidae: Apple tentiform leafminer or spotted tentiform leafminer

Phyllonorycter malimalifoliella - Lepidoptera, Gracillariidae: Spotted tentiform leafminer

Phyllonorycter manni - Lepidoptera, Gracillariidae

Phyllonorycter messaniella - Lepidoptera, Gracillariidae: Zellar's midget

Phyllonorycter millierella - Lepidoptera, Gracillariidae

Phyllonorycter nicellii - Lepidoptera, Gracillariidae

Phyllonorycter nipponicella - Lepidoptera, Gracillariidae

Phyllonorycter oxyacanthae - Lepidoptera, Gracillariidae

Phyllonorycter pastorella - Lepidoptera, Gracillariidae

Phyllonorycter platani - Lepidoptera, Gracillariidae

Phyllonorycter platanoidella - Lepidoptera, Gracillariidae 
Phyllonorycter pomifoliella - Lepidoptera, Gracillariidae

Phyllonorycter populifoliella - Lepidoptera, Gracillariidae

Phyllonorycter pyrifoliella - Lepidoptera, Gracillariidae

Phyllonorycter quercifoliella - Lepidoptera, Gracillariidae

Phyllonorycter quinnata - Lepidoptera, Gracillariidae

Phyllonorycter rajella - Lepidoptera, Gracillariidae

Phyllonorycter ringoniella - Lepidoptera, Gracillariidae: Apple leafminer

Phyllonorycter robiniella - Lepidoptera, Gracillariidae: Horse-chesnut leafminer

Phyllonorycter roboris - Lepidoptera, Gracillariidae

Phyllonorycter sagitella - Lepidoptera, Gracillariidae

Phyllonorycter salicicolella - Lepidoptera, Gracillariidae

Phyllonorycter salictella - Lepidoptera Gracillariidae

Phyllonorycter schreberella - Lepidoptera, Gracillariidae

Phyllonorycter scitulella - Lepidoptera, Gracillariidae

Phyllonorycter sorbi - Lepidoptera, Gracillariidae

Phyllonorycter spinolella - Lepidoptera, Gracillariidae

Phyllonorycter stettinensis - Lepidoptera, Gracillariidae

Phyllonorycter strigulatella - Lepidoptera, Gracillariidae

Phyllonorycter tenerella - Lepidoptera, Gracillariidae

Phyllonorycter tremulae - Lepidoptera, Gracillariidae

Phyllonorycter tritorrhecta - Lepidoptera, Gracillariidae

Phyllonorycter ulmifoliella - Lepidoptera, Gracillariidae

Phyllonorycter viminetorum - Lepidoptera, Gracillariidae

Phyllotreta zimmermanni - Coleoptera, Chrysomelidae

Physocephala sagittaria - Diptera, Conopidae

Physocephala texana - Diptera, Conopidae

Phytodietus polyzonias - Hymenoptera, Ichneumonidae

Phytomyza ilicicola - Diptera, Agromyzidae: Native holly leafminer

Phytomyza ilicis - Diptera, Agromyzidae: Holly leafminer

Phytomyza minuscula - Diptera, Agromyzidae

Phytomyza obscura - Diptera, Agromyzidae

Phytomyza phillyreae - Diptera, Agromyzidae

Phytomyza ranunculi - Diptera, Agromyzidae

Phytomyza rufipes - Diptera, Agromyzidae

Phytomyza spondylii - Diptera, Agromyzidae

Pieris rapae - Lepidoptera, Pieridae: Cabbage white

Piezotrachelus varium - Coleoptera, Brentidae

Pigeria piger - Hymenoptera, Braconidae

Pimpla aquilonia - Hymenoptera, Ichneumonidae

Pissodes strobe - Coleoptera, Curculionidae

Plagiodera versicolora - Coleoptera, Chrysomelidae

Plagiotrochus coriceus - Hymenoptera, Cynipidae

Plagiotrochus fusifex - Hymenoptera, Cynipidae

Plagiotrochus kiefferianus - Hymenoptera, Cynipidae

Plesispa reichei - Coleoptera, Chrysomelidae: Two-colored coconut leaf beetle

Pleuroptya ruralis - Lepidoptera, Pyralidae: Mother of pearl 
Pleurotroppopsis podagrica - Hymenoptera, Eulophidae

Plutella xylostella - Lepidoptera, Plutellidae: Diamond back moth or cabbage moth

Pnigalio pectinicornis - Hymenoptera, Eulophidae

Prays oleae - Lepidoptera, Plutellidae: Olive kernel borer or olive moth

Procerata sacchariphaga - Lepidoptera, Brachodidae

Promecotheca cumingii - Coleoptera, Hispidae: coconut leafminer

Promecotheca nuciferae - Coleoptera, Chrysomelidae: Coconut leafminer

Promecotheca opacicollis - Coleoptera, Hispidae

Promecotheca papuana - Coleoptera, Hispidae

Promecotheca reichei - Coleoptera, Chrysomelidae: Coconut leaf mining beatle or palm leaf mining beetle

Pseudaletia unipuncta - Lepidoptera, Noctuidae: Armyworm moth

Pseudogaurax anchora - Diptera, Chloropidae

Pseudoplusia includens - Lepidoptera, Noctuidae: Soybean looper

Psyche casta - Lepidoptera, Psychidae: Bagworm moth

Psychophagus omnivorus - Hymenoptera, Pteromalidae

Pteromalus phycidis - Hymenoptera, Pteromalidae

Ptycholomoides aeriferanus - Lepidoptera, Tortricidae

Rabdophaga justini - Diptera, Cecidomyiidae

Rabdophaga purpureaperda - Diptera, Cecidomyiidae

Rabdophaga saliciperda - Diptera, Cecidomyiidae: Willow shot-hole midge

Rabdophaga salicis - Diptera, Cecidomyiidae

Recurvaria leucatella - Lepidoptera, Gelechiidae: Lesser budmoth

Rhamphus oxyacanthae - Coleoptera, Curculionidae

Rhyacionia duplana - Lepidoptera, Tortricidae: Pine tip moth

Ropalidia notatipennis - Hymenoptera, Vespidae

Rynchaenus alni - Coleoptera, Curculionidae

Rynchaenus pallicornis - Coleoptera, Curculionidae

Rynchaenus quercus - Coleoptera, Curculionidae: Oak flea weevil

Scambus calobatus - Hymenoptera, Ichneumonidae

Scaptomyza flava - Diptera, Drosophilidae

Sceliodes laisalis - Lepidoptera, Pyralidae

Sculna forda - Lepidoptera, Saturniidae

Schizonotus latus - Hymenoptera, Pteromalidae

Scythris monochreella - Lepidoptera, Scythridae

Sesamia calamistis - Lepidoptera, Noctuidae: African pink borer

Sesamia cretica - Lepidoptera, Noctuidae: Durra stem borer

Sesamia inferens - Lepidoptera, Noctuidae: Pink stem borer

Sesamia nonagrioides - Lepidoptera, Noctuidae: Corn stalk borer

Sesamia penniseti - Lepidoptera, Noctuidae

Sesamia poephaga - Lepidoptera, Noctuidae

Silliana hommei - Hymenoptera, Tenthredinidae

Solygia sulcatifrons - Mantodea, Mantidae

Sparganothis pilleriana - Lepidoptera, Tortricidae: Long palped tortrix

Sphecodina abbotti - Lepidoptera, Sphingidae: Abbot's sphinx moth

Sphegigaster pallicornis - Hymenoptera, Pteromalidae 
Sphodromantis gastrica - Mantodea, Mantidae Sphodromantis viridis - Mantodea, Mantidae Spodoptera exigua - Lepidoptera, Noctuidae: Beet armyworm Spodoptera litura - Lepidoptera, Noctuidae: Tobacco cutworm or cluster caterpillar Stictococcus sjostedti - Hemiptera, Coccidae Stiropius bucculatricis - Hymenoptera, Braconidae Symmerista albifrons - Lepidoptera, Notodontidae: White-headed prominent Sympiesis aburiana - Hymenoptera, Eulophidae Sympiesis sericeicornis - Hymenoptera, Eulophidae Synagris cornuta - Hymenoptera, Vespidae Telenomus gowdeyi - Hymenoptera, Scelionidae Tetramesa angustipenne - Hymenoptera, Eurytomidae Tetramesa brevicollis - Hymenoptera, Eurytomidae Tetramesa calamagrostide - Hymenoptera, Eurytomidae Tetramesa eximia - Hymenoptera, Eurytomidae Tetramesa fulvicollis - Hymenoptera, Eurytomidae Tetramesa hyalipennis - Hymenoptera, Eurytomidae Tetramesa linearis - Hymenoptera, Eurytomidae Tetramesa longula - Hymenoptera, Eurytomidae Tetramesa petiolata - Hymenoptera, Eurytomidae Tetramesa phleicola - Hymenoptera, Eurytomidae Tetrastichus miser - Hymenoptera, Eulophidae Thaumetopoea pityocampa - Lepidoptera, Thaumetopoeidae: Pine procession moth Thymelicus lineola - Lepidoptera, Heperiidae: Essex skipper or European skipper Tischeria dodonaea - Lepidoptera, Tischeriidae Tischeria malifoliella - Lepidoptera, Tischeriidae: Apple leaf trumpet miner Tortrix capensana - Lepidoptera, Tortricidae: Apple leaf roller

Tortrix viridana - Lepidoptera, Tortricidae: European oak leafroller

Trachelus tabidus - Hymenoptera, Cephidae: Black grain stem sawfly Trachylepidia fructicassiella - Lepidoptera, Pyralidae Tranosema nigricans - Hymenoptera, Ichneumonidae Tranosema rostrale - Hymenoptera, Ichneumonidae: Spruce budworm parasitoid or campoplegine wasp

Triaspis pallipes - Hymenoptera, Braconidae

Trichiocampus ulmi - Hymenoptera, Tenthredinidae: Nematine sawfly

Trichomalopsis hemiptera - Hymenoptera, Pteromalidae

Trichomalopsis peregrina - Hymenoptera, Pteromalidae

Trichoplusia ni - Lepidoptera, Noctuidae: Cabbage looper

Trifurcula headleyella - Lepidoptera, Nepticulidae

Trigonaspis megaptera - Hymenoptera, Cynipidae

Tromatobia oculatoria - Hymenoptera, Ichneumonidae

Tromatobia rufopectus - Hymenoptera, Ichneumonidae

Winthemia datanae - Diptera, Tachinidae

Yponomeuta cagnagella - Lepidoptera, Yponomeutidae: Spindle ermine Yponomeuta evonymella - Lepidoptera, Yponomeutidae: Bird-cherry ermine Yponomeuta malinella - Lepidoptera, Yponomeutidae: Apple ermine moth 
Yponomeuta padella - Lepidoptera, Yponomeutidae: Small ermine moth

Yponomeuta rorrella - Lepidoptera, Yponomeutidae

Ypsolopha coriacella - Lepidoptera, Ypsolophidae

Zaglyptus iwatai - Hymenoptera, Ichneumonidae

\section{Subfamily Entedoninae not in CA or AZ}

\section{Achrysocharoides}

Host:

Antispila metallella - Lepidoptera, Heliozelidae

Antispila treitschkiella - Lepidoptera, Heliozelidae

Caloptilia alchimiella - Lepidoptera, Gracillariidae

Caloptilia ulmi - Lepidoptera, Gracillariidae

Chrysaster hagicola - Lepidoptera, Gracillariiadae

Coleophora limosipennella - Lepidoptera, Coleophoridae

Coleotechnites starki - Lepidoptera, Gelechiidae: Northern lodgepole needleminer

Palaeocimbex quadrimaculata - Hymenoptera, Cimbicidae

Dichomeris marginella - Lepidoptera, Gelechiidae: Juniper webworm

Ectoedemia atricollis - Lepidoptera, Nepticulidae

Emmetia angusticolella - Lepidoptera, Tischeriidae

Emmetia heinemanni - Lepidoptera, Tischeriidae

Gracillaria japonica - Lepidoptera, Gracillariidae

Gracillaria rhoifoliella - Lepidoptera, Gracillariidae

Hyloconis puerariae - Lepidoptera, Gracillariidae

Leucoptera coffeella - Lepidoptera, Lyonetiidae: Coffee leafminer

Leucoptera malifoliella - Lepidoptera, Lyonetiidae: Pear leaf blister moth or pear leaf miner

Liocrobyla desmodiella - Lepidoptera, Gracillariidae

Liocrobyla lobata - Lepidoptera, Gracillariidae

Lyonetia clerkella - Lepidoptera, Lyonetiidae: Apple leaf miner

Neolithocolletis hikomonticola - Lepidoptera, Gracillariidae

Palexorista solennis - Diptera, Tachinidae

Parornix devoniella - Lepidoptera, Gracillariidae

Parornix petiolella - Lepidoptera, Gracillariidae

Phyllocnistis citrella- Lepidoptera, Gracillariidae: Citrus leafminer

Phyllonorycter acerifoliella - Lepidoptera, Gracillariidae

Phyllonorycter acernella - Lepidoptera Gracillariidae

Phyllonorycter bicinctella - Lepidoptera, Gracillariidae

Phyllonorycter blancardella- Lepidoptera, Gracillariidae: Spotted tentiform leafminer

Phyllonorycter carpini - Lepidoptera, Gracillariidae

Phyllonorycter cavella - Lepidoptera, Gracillariidae

Phyllonorycter celtidis - Lepidoptera, Gracillariidae

Phyllonorycter celtisella - Lepidoptera, Gracillariidae

Phyllonorycter comparella - Lepidoptera, Gracillariidae

Phyllonorycter corylifoliella - Lepidoptera, Gracillariidae: Hawthorn red midget moth

Phyllonorycter crataegella- Lepidoptera Gracillariidae: Apple blotch leafminer

Phyllonorycter distentella - Lepidoptera, Gracillariidae 
Phyllonorycter elmaella - Lepidoptera Gracillariidae: Western tentiform leafminer

Phyllonorycter emberizaepennella - Lepidoptera Gracillariidae

Phyllonorycter froelichiella - Lepidoptera Gracillariidae

Phyllonorycter geniculella - Lepidoptera Gracillariidae

Phyllonorycter harrisella - Lepidoptera Gracillariidae

Phyllonorycter heegeriella - Lepidoptera Gracillariidae

Phyllonorycter insignitella - Lepidoptera Gracillariidae

Phyllonorycter joannisi - Lepidoptera Gracillariidae

Phyllonorycter kleemannella - Lepidoptera Gracillariidae

Phyllonorycter lucetiella - Lepidoptera Gracillariidae: Basswood squareblotch miner

Phyllonorycter lucidicostella - Lepidoptera Gracillariidae: Lesser maple leafblotch miner

Phyllonorycter maestingella - Lepidoptera Gracillariidae

Phyllonorycter manni - Lepidoptera, Gracillariidae

Phyllonorycter messaniella - Lepidoptera, Gracillariidae: Zellar's midget

Phyllonorycter nicellii - Lepidoptera, Gracillariidae

Phyllonorycter nigrescentella - Lepidoptera, Gracillariidae

Phyllonorycter ostryaefoliella - Lepidoptera, Gracillariidae

Phyllonorycter oxyacanthae - Lepidoptera, Gracillariidae

Phyllonorycter pomifoliella - Lepidoptera, Gracillariidae

Phyllonorycter populifoliella - Lepidoptera, Gracillariidae

Phyllonorycter propinquinella -Lepidoptera, Gracillariidae: Cherry blotchminer

Phyllonorycter pygmaea -Lepidoptera, Gracillariidae

Phyllonorycter pyrifoliella -Lepidoptera, Gracillariidae

Phyllonorycter quercifoliella - Lepidoptera, Gracillariidae

Phyllonorycter quinnata - Lepidoptera, Gracillariidae

Phyllonorycter quinqueguttella - Lepidoptera, Gracillariidae

Phyllonorycter rajella - Lepidoptera, Gracillariidae

Phyllonorycter ringoniella - Lepidoptera, Gracillariidae: Apple leafminer

Phyllonorycter roboris - Lepidoptera, Gracillariidae

Phyllonorycter salicicolella -Lepidoptera, Gracillariidae

Phyllonorycter salictella - Lepidoptera Gracillariidae

Phyllonorycter schreberella -Lepidoptera, Gracillariidae

Phyllonorycter similes -Lepidoptera, Gracillariidae

Phyllonorycter sorbi - Lepidoptera, Gracillariidae

Phyllonorycter sorbicola - Lepidoptera, Gracillariidae

Phyllonorycter strigulatella -Lepidoptera, Gracillariidae

Phyllonorycter tenerella - Lepidoptera, Gracillariidae

Phyllonorycter tiliacella - Lepidoptera Gracillariidae: Basswood roundblotch miner

Phyllonorycter tremuloidiella - Lepidoptera, Gracillariidae: Aspen blotchminer

Phyllonorycter ulmifoliella - Lepidoptera, Gracillariidae

Phyllonorycter viciae -Lepidoptera, Gracillariidae

Phyllonorycter watanabei -Lepidoptera, Gracillariidae

Porphyrosela desmodiella - Lepidoptera, Gracillariidae

Spulerina dissotoma - Lepidoptera, Gracillariidae

Stigmella betulicola - Lepidoptera, Nepticulidae

Stigmella floslactella - Lepidoptera, Nepticulidae 
Stigmella hybnerella - Lepidoptera, Nepticulidae

Stigmella minusculella - Lepidoptera, Nepticulidae

Stigmella ruficapitella - Lepidoptera, Nepticulidae

Stigmella salicis - Lepidoptera, Nepticulidae

Tischeria ekebladella - Lepidoptera, Tischeriidae

\section{Subfamily Entedoninae not in USA}

Achrysocharis (subgenus of Closterocerus)

Host:

Acalyptris loranthella - Lepidoptera, Nepticulidae

Caligo ilcoxiens - Lepidoptera, Nymphalidae: Owl butterfly

Chromatomyia syngenesiae - Diptera, Agromyzidae: Chrysanthemum leafminer

Exoteleia nepheos - Lepidoptera, Gelechiidae

Hydrellia griseola - Diptera, Ephydridae

Leucoptera coffeella - Lepidoptera, Lyonetiidae: Coffee leafminer

Leucoptera malifoliella - Lepidoptera, Lyonetiidae: Pear leaf blister moth or pear leafminer

Leucoptera meyricki- Lepidoptera, Lyonetiidae: Coffee leafminer

Melanagromyza - Diptera, Agromyzidae

Ocnerostoma piniariellum - Lepidoptera, Yponomeutidae: Ermine moth

Phyllonorycter blancardella- Lepidoptera, Gracillariidae: Spotted tentiform leafminer

Plesispa nipae - Coleoptera, Hispinae

Promecotheca reichei - Coleoptera: Chrysomelidae: Coconut leaf mining beatle or palm leaf mining beetle

Stigmella carpinella - Lepidoptera, Nepticulidae

\section{Apleurotropis}

Host:

Acrocercopus - Lepidoptera, Gracillariidae

Cerodontha bisetiorbita - Diptera, Agromyzidae

Cosmopterix - Lepidoptera, Cosmopterigidae

Crobylophora daricella - Lepidoptera, Lyonetiidae

Leucoptera coffeella- Lepidoptera, Lyonetiidae: coffee leafminer

Leucoptera meyricki - Lepidoptera, Lyonetiidae: Coffee leafminer

Ophiomyia solanicola - Diptera, Agromyzidae

Phylacteophaga eucalypti - Hymenoptera, Pergidae: Eucalyptus leaf-blister sawfly

Phyllonorycter - Lepidoptera, Gracillariidae

Promecotheca csiki - Coleoptera, Chrysomelidae: coconut leafminer

Promecotheca papuana - Coleoptera, Chrysomelidae: Coconut leafminer

\section{Kratoysma}

Host:

Phyllocnistis citrella - Lepidoptera, Gracillariidae: Citrus leafminer

Pyllocnistis citri - Lepidoptera, Gracillariidae: citrus leafminer

Phyllocnistis unipunctella - Lepidoptera, Gracillariidae: Poplar leafminer

Traumatocampa pinivora - Lepidoptera: Pine procession moth 


\section{Pleurotroppopsis}

Host:

Acrocercops diffluella - Lepidoptera, Gracillariidae

Aristaea asteris - Lepidoptera

Cerodontha bisetiorbita

Chrysaster hagicola - Lepidoptera, Gracillariiadae

Coelaenomendera elaeidis

Cosmopterix phyllostachysea - Lepidoptera, Cosmopterigidae: Pubescent bamboo miner

Lyonetia clerkella - Lepidoptera, Lyonetiidae: Apple leafminer

Napomyza xylostei - Diptera, Agromyzidae

Phyllonorycter issikii - Lepidoptera, Gracillariidae

Phyllonorycter leucocorona - Lepidoptera, Gracillariidae

Phyllonorycter lyoniae - Lepidoptera, Gracillariidae

Phyllonorycter ringoniella - Lepidoptera, Gracillariidae: Apple leafminer

Phyllonorycter similes - Lepidoptera, Gracillariidae

Promecotheca cumingii - Coleoptera, Hispidae: coconut leafminer

\section{Proacrias}

Host:

Bedellia somnulentella -Lepidoptera, Lyonetiidae: Sweet potato leafminer

Hispa stygia - Coleoptera, Chrysomelidae:

Leucoptera coffeella- Lepidoptera, Lyonetiidae: coffee leafminer

Liriomyza - Diptera, Agromyzidae

Ophiomyia spencerella - Diptera, Agromyzidae: Bean-stem maggot or beanfly

Phytoliriomyza jacarandae - Diptera, Agromyzidae: Jacaranda leafminer

\section{Sarasvatia}

Host:

Stigmella ipomoella - Lepidoptera, Nepticulidae

\section{Shardiella}

Host:

Agromyzidae

\section{Trisecodes}

Host:

Calycomyza sidae - Diptera, Agromyzidae

Liriomyza - Diptera, Agromyzidae

Melangromyza cassiae - Diptera, Agromyzidae

\section{Zaommomentedon}

Host:

Phyllocnistis citrella - Lepidoptera, Gracillariidae: Citrus leafminer 


\section{Subfamily Euderinae in CA}

\section{Euderus}

Host:

Aciurina thoracica - Diptera, Tephritidae

Acrobasis caryae - Lepidoptera, Pyralidae: Hickory shoot borer

Acrobasis juglandis - Lepidoptera, Pyralidae: Pecan leaf casebearer

Acrocercops dives - Lepidoptera, Gracillariidae

Adaina microdactyla - Lepidoptera, Pterophoridae

Agrilus aurichalceus - Coleoptera, Buprestidae: Rose stem girdler

Agrilus criddlei - Coleoptera, Buprestidae

Agrilus suvorovi - Coleoptera, Buprestidae

Agrilus viridis - Coleoptera, Buprestidae: Beech splendour beetle

Alcides leeuweni - Coleoptera, Curculionidae

Anarsia lineatella- Lepidoptera, Chelariinae: Peach twig borer

Apanteles laricellae - Hymenoptera, Braconidae

Argyresthia alternatella - Lepidoptera, Agyresthiidae

Argyresthia laricella - Lepidoptera, Agyresthiidae: Larch shoot moth

Attelabus rhois - Coleoptera, Attelabidae

Bactrocera oleae- Diptera, Tephritidae: Olive fruit fly

Bedellia orchilella - Lepidoptera, Lyonetiidae: Sweetpotato leafminer

Blastotere thuiella - Lepidoptera, Agyresthiidae

Bracon variabilis - Hymenoptera, Braconidae

Carpomya vesuviana - Diptera, Tephritidae

Ceutorhynchus rapae - Coleoptera, Curculionidae

Coleophora alticolella - Lepidoptera, Coleophoridae

Coleophora caespititiella - Lepidoptera, Coleophoridae

Coleophora gallipennella - Lepidoptera, Coleophoridae

Coleophora laricella - Lepidoptera, Coleophoridae: Larch casebearer or larch leaf miner

Coleophora parthenica - Lepidoptera, Coleophoridae: Russian thistle stem miner

Coleophora pruniella - Lepidoptera, Coleophoridae

Coleophora serratella- Lepidoptera, Coleophoridae: Birch casebearer or cigar casebearer

Coleotechnites milleri - Lepidoptera, Gelechiidae: Lodgepole needleminer

Coleotechnites starki - Lepidoptera, Gelechiidae: Northern lodgepole needleminer

Cryptophlebia culpes - Lepidoptera, Tortricidae: False codling moth

Cydia pomonella - Lepidoptera, Tortricidae: Codling moth

Cylas formicarius - Coleoptera, Brentidae: Sweetpotato weevil

Cylindrocopturus furnissi - Coleoptera, Curculionidae: Douglas fir twig weevil

Desmia funeralis - Lepidoptera, Pyralidae: Grape leaf folder

Dioryctria zimmermani - Lepidoptera, Pyralidae: Zimmerman pine moth

Dryocosmus coxii - Hymenoptera, Cynipidae

Epiblema obfuscana - Lepidoptera, Tortricidae

Epiblema strenuana - Lepidoptera, Tortricidae: Parthenium stemgalling moth

Epinotia nanana - Lepidoptera, Tortricidae: European spruce needle miner

Etainia sericopeza - Lepidoptera, Nepticulidae

Eucosma recissoriana - Lepidoptera, Tortricidae: Lodgepole pine cone borer

Faustinus cubae - Coleoptera, Curculionidae 
Gonipterus scutellatus- Coleoptera, Curculionidae: Eucalyptus snout beetle or Australian weevil

Gracillaria mabaella - Lepidoptera, Gracillariidae

Grapholita molesta - Lepidoptera, Tortricidae: Oriental fruit moth

Grapholita packardi - Lepidoptera, Tortricidae: Cherry fruitworm

Hartigia xanthostoma - Hymenoptera, Cephidae

Helotorus argyresthiae - Hymenoptera, Ichneumonidae

Heterocrossa inscripta - Lepidoptera, Carposinidae

Heterocrossa subumbrata - Lepidoptera, Carposinidae

Hylesinus oleiperda - Coleoptera, Scolytidae

Hypolixus truncatulus - Coleoptera, Curculionidae: Amaranth weevil

Hyposmocoma liturata - Lepidoptera, Cosmopterigidae

Lestodiplosis septemguttata - Diptera, Cecidomyiidae

Leucoptera coffeella - Lepidoptera, Lyonetiidae: Coffee leafminer

Lonchaea bruneri - Diptera, Lonchaeidae

Lophobaris piperis - Coleoptera, Curculionidae: Pepper weevil

Lymantria monacha - Lepidoptera, Lymantriidae: Black arches

Mehteria hemidoxa - Lepidoptera, Tortricidae

Melanagromyza obtuse - Diptera, Agromyzidae

Monoptilota pergratialis - Lepidoptera, Pyralidae: Limabean vine borer

Natada nararia - Lepidoptera, Limacodidae: Nettle grub, fringed nettle grub or slug caterpillar

Oberea bimaculata - Coleoptera, Cerambycidae: Raspberry cane borer

Oberea tripunctata - Coleoptera, Cerambycidae: Dogwood twig borer

Parectopa epibathra - Lepidoptera, Gracillariidae

Parectopa marginestrigata - Lepidoptera, Gracillariidae

Parthenolecanium corni - Hemiptera, Coccidae: European fruit lecanium

Pempheres affinis - Coleoptera, Curculionidae: Cotton-stem weevil

Phyllonorycter harrisella - Lepidoptera Gracillariidae

Plagiotrochus suberi - Hymenoptera, Cynipidae

Polychrosis viteana - Lepidoptera, Tortricidae: Grape berry moth

Prays acmonias - Lepidoptera, Plutellidae

Prays citri - Lepidoptera, Plutellidae: Citrus flower moth

Prays endocarpa - Lepidoptera, Plutellidae: Citrus fruit moth

Proteoteras willingana - Lepidoptera, Tortricidae: Boxelder twig borer

Rhyacionia buoliana - Lepidoptera, Tortricidae: European pine shoot moth

Rhyacionia frustrana - Lepidoptera, Tortricidae: Nantucket pine tip moth

Saperda carcharias - Coleoptera, Cerambycidae: Poplar longhorned beetle, large poplar borer or poplar borer

Saperda inornata - Coleoptera, Cerambycidae: Poplar gall borer

Saperda populnea - Coleoptera, Cerambycidae: Small poplar borer

Sesioplex depressus - Hymenoptera, Ichneumonidae

Scolytus intricatus - Coleoptera, Scolytidae: European oak bark beetle

Scolytus kirschi - Coleoptera, Scolytidae: Kirsch bark beetle

Sphenoptera gossypii - Coleoptera, Buprestidae: Cotton stem borer

Spilonota ocellana - Lepidoptera, Tortricidae: Eye-spotted budmoth 
Stigmella malella - Lepidoptera, Nepticulidae: Banded apple pigmy

Symmetrischema capsica - Lepidoptera, Gelechiidae: Pepper flower bud moth

Thopeutis forbesellus - Lepidoptera, Pyralidae

Zeuzera pyrina - Lepidoptera, Cossidae: Leopard moth

Zoophthorus laricellae - Hymenoptera, Ichneumonidae

\section{Astichus}

Host:

Bolitotherus cornutus - Coleoptera, Tenebrionidae: Forked fungus beetle

Brachycis breviollis - Coleoptera, Cisidae

Ceracis sallei - Coleptera, Cisidae

Cis bolet - Coleoptera, Cisidae

Cis comptus - Coleoptera, Cisidae

Cis glabratus - Coleoptera, Ciidae

Cis hispidus - Coleoptera, Ciidae

Cis micans - Coleoptera, Ciidae

Cis seriatopilosus - Coleoptera, Ciidae

Dolichocis manitoba - Coleoptera, Ciidae

Ennearthron affine - Coleoptera, Ciidae

Ennearthron cornutum - Coleoptera, Ciidae

Liriomyza pictella - Diptera, Agromyzidae: Melon leafminer

Octotemnus glabriculus - Coleoptera, Ciidae

Octotemnus laminifrons - Coleoptera, Ciidae

Parectopa robiniella - Lepidoptera, Gracillariidae: Locust digitate leafminer

Phyllonorycter robiniella - Lepidoptera, Gracillariidae: Horse-chesnut leafminer

Rhopalodontus fronticornis - Coleoptera, Ciidae

Shindus dubius

Xylographus - Coleoptera, Scolytidae

\section{Subfamily Tetrastichinae in California}

\section{Galeopsomyia}

Host:

Asphondylia borrichiae - Diptera, Cecidomyiidae

Asphondylia floccose - Diptera, Cecidomyiidae

Asphondylia globules - Diptera, Cecidomyiidae

Asphondylia helianthiglobula - Diptera, Cecidomyiidae

Asphondylia websteri - Diptera, Cecidomyiidae

Belonocnema treatae - Hymenoptera, Cynipidae

Chalcodermus inaequicollis - Coleoptera, Curculionidae

Phyllocnistis citrella - Lepidoptera, Gracillariidae: Citrus leafminer

Procecidochares utilis - Diptera, Tephritidae: Crofton weed gall fly

Rhopalomyia - Diptera, Cecidomyiidae

Rileya cecidomyiae - Hymenoptera, Eurytomidae

Tenuipetiolus teredon - Hymenoptera, Eurytomidae

Torymus umbilicatus - Hymenoptera, Torymidae 


\section{Quadrastichus}

Host:

Ageniaspis citricola - Hymenoptera, Encyrtidae

Agrilus viridis - Coleoptera, Buprestidae: Beech splendour beetle

Anisostephus betulinum - Diptera, Cecidomyiidae

Cimbex femorata - Hymenoptera, Cimbicidae: Button horn sheep wasp

Cylindrocopturus adspersus - Coleoptera, Curculionidae: Sunflower stem weevil

Dasineura balsamicola - Diptera, Cecidomyiidae

Dasineura filicina - Diptera, Cecidomyiidae

Dasineura ulmariae - Diptera, Cecidomyiidae

Diaprepes abbreviatus - Coleoptera, Curculionidae: Diaprepes root weevil

Diaprepes famelicus - Coleoptera, Curculionidae

Diaprepes quadrivittatus - Coleoptera, Curculionidae

Eurosta solidaginis - Diptera, Tephritidae: Goldenrod gall fly

Harmandiola tremulae - Diptera, Cecidomyiidae

Iteomyia capreae - Diptera, Cecidomyiidae

Kermes corticalis - Hemiptera, Kermesidae

Kermes quercus - Hemiptera, Kermesidae

Kermes roboris - Hemiptera, Kermesidae

Leucoptera malifoliella - Lepidoptera, Lyonetiidae: Pear leaf blister moth or pear leaf miner

Liriomyza trifolii - Diptera, Agromyzidae: American serpentine leafminer

Lyonetia clerkella - Lepidoptera, Lyonetiidae: Apple leaf miner

Massalongia betulifolia - Diptera, Cecidomyiidae

Massalongia rubra - Diptera, Cecidomyiidae

Mayetiola destructor - Diptera, Cecidomyiidae: Hessian fly

Monarthropalpus buxi - Diptera, Cecidomyiidae

Mordellistena pustulata - Coleoptera, Mordellidae: Tumbling flower beetle

Neuroterus quercusverrucarum - Hymenoptera, Cynipidae

Pachnaeus litus - Coleoptera, Curculionidae: Citrus root weevil or blue green citrus root weevil

Pachnaeus opalus - Coleoptera, Curculionidae: Citrus root weevil or blue green citrus root weevil

Paragaleopsomyia femorata - Hymenoptera, Eulophidae

Phyllocnistis citrella - Lepidoptera, Gracillariidae: Citrus leafminer

Physonota unipunctata - Coleoptera, Chrysomelidae: Green tortoise beetle

Prepodes similes - Coleoptera, Curculionidae

Prepodes vittatus - Coleoptera, Curculionidae

Quadrastichus brevinervis - Hymenoptera, Eulophidae

Quadrastichus ventricosus - Hymenoptera, Eulophidae

Rabdophaga pseudococcus - Diptera, Cecidomyiidae

Rhopalomyia chrysanthemi - Diptera, Cecidomyiidae: Chrysanthemum gall midge

Torymus chloromerus - Hymenoptera, Torymidae

Wachtliella persicariae - Diptera, Cecidomyiidae

Wachtliella rosarum - Diptera, Cecidomyiidae 


\section{Tetrastichus}

Host:

Achaea janata - Lepidoptera, Nepticulidae: Croton caterpillar

Acrobasis nuxvorella - Lepidoptera, Pyralidae: Pecan nut casebearer

Acronicta americana - Lepidoptera, Noctuidae: American dagger moth

Adalia bipunctata - Coleoptera, Coccinellidae: Two-spot lady bird or two-spotted lady

beetle

Adelencyrtus mayurai - Hymenoptera, Encyrtidae

Adelencyrtus moderatus - Hymenoptera, Encyrtidae

Aethognathus cavilabris - Hymenoptera, Encyrtidae

Ageniaspis citricola - Hymenoptera, Encyrtidae

Ageniella bombycina - Hymenoptera, Pompilidae

Agrilus arcuatus - Coleoptera, Buprestidae: Hickory spiral borer

Agrilus aurichalceus - Coleoptera, Buprestidae: Rose stem girdler

Agrilus integerrimus - Coleoptera, Buprestidae

Agrilus sinuatus - Coleoptera, Buprestidae: Hawthorn jewel beetle

Agrilus viridis - Coleoptera, Buprestidae: Beech splendour beetle

Alabama argillacea - Lepidoptera, Noctuidae: Cotton leafworm

Aleiodes circumscriptus - Hymenoptera, Braconidae

Aleurodicus destructor - Hemiptera, Aleyrodidae: Coconut whitefly

Allantus cinctus - Hymenoptera, Tenthredinidae: Curled rose sawfly

Alurnus humeralis - Coleoptera, Chrysomelidae

Anadevidia peponis - Lepidoptera, Noctuidae

Anagyrus lopezi - Hymenoptera, Encyrtidae

Anisostephus betulinum - Diptera, Cecidomyiidae

Anisota senatoria - Lepidoptera, Saturniidae: Orangestriped oakworm or orange-tipped oakworm

Anomalococcus crematogastri - Hemiptera, Asterolecaniidae

Anomis leona - Lepidoptera, Noctuidae

Anoplius nigerrimus - Hymenoptera, Pompilidae

Anthonomus consors - Coleoptera, Curculionidae: Cherry curclio

Antigastra catalaunalis - Lepidoptera, Pyralidae: Sesame podborer or sesame webworm Apanteles laorae - Hymenoptera, Braconidae Apanteles machaeralis - Hymenoptera, Braconidae

Apanteles syleptae - Hymenoptera, Braconidae

Apanteles taragamae - Hymenoptera, Braconidae

Apanteles venustus - Hymenoptera, Braconidae

Apion apricans - Coleoptera, Apionidae: Clover seed weevil

Apion flavofemoratum - Coleoptera, Apionidae

Apis mellifera - Hymenoptera, Apidae: Honey bee

Apriona germarii - Coleoptera, Cerambycidae

Apriona rugicollis - Coleoptera, Cerambycidae

Aproaerema modicella - Lepidoptera, Gelechiidae: Groundnut leafminer

Aprostocetus asthenogmus - Hymenoptera, Eulophidae

Aprostocetus hagenowii - Hymenoptera, Eulophidae

Arge ochropa - Hymenoptera, Argidae 
Arge pagana - Hymenoptera, Argidae: Rose sawfly

Arge pectoralis - Hymenoptera, Argidae: Birch sawfly

Arge rosae - Hymenoptera, Argidae: Rose sawfly

Arge scapularis - Hymenoptera, Argidae: Elm argid sawfly

Argopus ahrensi - Coleoptera, Chrysomelidae

Argyresthia freyella - Lepidoptera, Argyresthiidae: Arborvitae leafminer

Ariadne merione - Lepidoptera, Nymphalidae: Common castor

Arsenura xanthopus - Lepidoptera, Saturniidae

Artona catoxantha - Lepidoptera, Zygaenidae: Coconut leaf moth, coconut leaf

skeletonizer, Malayan coconut zygaenid, or Malayan coconut moth

Arytaina bicolor - Hemiptera, Psyllidae

Ascia monuste - Lepidoptera, Pieridae: Great southern white

Asphondylia riveae - Diptera, Cecidomyiidae

Aspidimorpha miliaris - Coleoptera, Chrysomelidae

Asterolecanium ilicicola - Hemiptera, Asterolecaniidae

Asteromyia carbonifera - Diptera, Cecidomyiidae

Athalia cordata - Hymenoptera, Tenthredinidae

Atherigona naqvii - Diptera, Muscidae: Shoot fly

Atherigona soccata - Diptera, Muscidae: Sorghum shoot fly

Atherigona varia - Diptera, Muscidae: Sorghum shoot fly

Attacus atlas - Lepidoptera, Saturniidae: Atlas moth

Aulacaspis tegalensis - Hemiptera, Diaspididae: Sugarcane scale

Australephestiodes stictella - Lepidoptera, Pyralidae

Austrolauthia spegazzinii - Diptera, Cecidomyiidae

Bactrocera cucurbitae - Diptera, Tephritidae: Melon fly

Bactrocera dorsalis - Diptera, Tephritidae: Oriental fruit fly

Bactrocera latifrons - Diptera, Tephritidae: Malayasian fruit fly

Bactrocera passiflorae - Diptera, Tephritidae: Fijian fruit fly

Bactrocera oleae - Diptera, Tephritidae: Olive fruit fly

Bactrocera tryoni - Diptera, Tephritidae: Queensland fruit fly

Bactrocera xanthodes - Diptera, Tephritidae: Pacific fruit fly

Barbara herrichiana - Lepidoptera, Tortricidae

Bassus rufipes - Hymenoptera, Braconidae

Bathytricha truncate - Lepidoptera, Noctuidae: Sugarcane borer or maize stemborer

Blastothrix scenographica - Hymenoptera, Encyrtidae

Blepharida rhois - Coleoptera, Chrysomelidae: Sumac flea beetle

Brachmia modicella - Lepidoptera, Gelechiidae

Brachonyx pineti - Coleoptera, Curculionidae

Bracon brevicornis - Hymenoptera, Braconidae

Bracon pectoralis - Hymenoptera, Braconidae

Brenthia leptocosma - Lepidoptera, Choreutidae

Brontispa froggatti - Coleoptera, Chrysomelidae: Coconut leaf beetle

Brontispa longissima - Coleoptera, Chrysomelidae: Palm leaf beetle, coconut leaf beetle

Brontispa mariana - Coleptera, Chrysomelidae: Mariana coconut leaf beetle

Brontispa palauensis - Coleptera, Chrysomelidae: Palau coconut leaf beetle

Bruchus obscurus - Coleoptera, Chrysomelidae 
Bucculatrix crataegi - Lepidoptera, Bucculatrigidae

Busseola fusca - Lepidoptera, Noctuidae: African maize stalk borer

Byturus tomentosus - Coleoptera, Byturidae: Raspberry Beetle

Cactoblastis cactorum - Lepidoptera, Pyralidae: Prickly pear moth or cactus moth

Calopepla leayana - Coleoptera, Chrysomelidae

Caloptilia theivora - Lepidoptera, Gracillariidae

Campoletis chlorideae - Hymenoptera, Ichneumonidae

Camptoloma interiorata - Lepidoptera, Noctuidae

Carcelia illota - Diptera, Tachinidae

Carpomya incomplete - Diptera, Tephritidae

Carpophthoromyia tritea - Diptera, Tephritidae

Cassida deflorata - Coleoptera, Chrysomelidae

Cassida murraea - Coleoptera, Chrysomelidae: Fleabane tortoise beetle

Cassida rubiginosa - Coleoptera, Chrysomelidae: Thistle tortoise beetle

Cassida sanguinosa - Coleoptera, Chrysomelidae

Cassida viridis - Coleoptera, Chrysomelidae

Cephus pygmaeus - Hymenoptera, Cephidae: Corn sawfly

Ceratitis capitata - Diptera, Tephritidae: Mediterranean fruit fly

Cerococcus hibisci - Hemiptera, Cerococcidae

Ceroplastes floridensis - Hemiptera, Coccidae: Florida wax scale

Ceroplastes grandis - Hemiptera, Coccidae

Ceroplastes japonicus - Hemiptera, Coccidae: Japanese wax scale

Ceroplastes pseudoceriferus - Hemiptera, Coccidae

Ceroplastes rusci - Hemiptera, Coccidae: Fig wax scale

Ceutorhynchus assimilis - Coleoptera, Curculionidae: Cabbage seed weevil

Ceutorhynchus quadridens - Coleoptera, Curculionidae

Chaetoptelius vestitus - Coleoptera, Curculionidae

Chaliopsis junodi - Lepidoptera, Psychidae

Cheilomenes lunata - Coleoptera, Coccinellidae

Cheilomenes vicina - Coleoptera, Coccinellidae

Chilo auricilius - Lepidoptera, Pyralidae: Sugarcane stalk borer

Chilo indicus - Lepidoptera, Pyralidae: Sugarcane internode borer

Chilo infuscatellus - Lepidoptera, Pyralidae: Sugarcane stem borer

Chilo partellus - Lepidoptera, Pyralidae: Spotted stalk borer

Chilo polychrysa - Lepidoptera, Pyralidae: Dark headed stem borer

Chilo suppressalis - Lepidoptera, Pyralidae: Asiatic rice borer or striped stemborer

Chilocorus bijugus - Coleoptera, Coccinellidae

Chilocorus bipustulatus - Coleoptera, Coccinellidae: Heather ladybird

Chilocorus kuwanae - Coleoptera, Coccinellidae: Red-spotted black lady beetle

Chilocorus pilosus - Coleoptera, Coccinellidae

Chilocorus renipustulatus - Coleoptera, Coccinellidae: Kidney-spot ladybird

Chirotica bruchii - Hymenoptera, Ichneumonidae

Chlamisus spilota - Coleoptera, Chrysomelidae

Chlorops novakii - Diptera, Chloropidae

Choristoneura fumiferana - Lepidoptera, Tortricidae: Spruce budworm

Chromatomyia syngenesiae - Diptera, Agromyzidae: Chrysanthemum leafminer 
Chrysobothris sexsignata - Coleoptera, Buprestidae

Chrysodeixis eriosoma - Lepidoptera, Noctuidae: Green looper

Chrysomela scripta - Coleoptera, Chrysomelidae: Cottonwood leaf beetle

Chrysomela vigintipunctata - Coeloptera, Chrysomelidae

Chrysopa boninensis - Neuroptera, Chrysopidae

Chrysopa carnea - Neuroptera, Chrysopidae: Goldeneye lacewing

Chrysoperla lacciperda - Neuroptera, Chrysopidae

Chunrocerus niveosparsus - Hemiptera, Cicadellidae

Cicadella spectra - Hemiptera, Cicadellidae

Cimbex femorata - Hymenoptera, Cimbicidae: Button horn sheep wasp

Cladius difformis - Hymenoptera, Tenthredinidae: Bristly roseslug or roseslug sawfly

Cladius pectinicornis - hymenoptera, Tenthredinidae

Clostera pigra - Lepidoptera, Notodontidae: Small chocolate-tip

Cnaphalocrocis medinalis - Lepidoptera, Pyralidae: Rice leaf roller

Coccidohystrix insolita - Hemiptera, Pseudococcidae

Coccinella novemnotata - Coleoptera, Coccinellidae: Nine-spotted ladybird beetle

Coccinella repanda - Coleoptera, Coccinellidae

Coccinella septempunctata - Coleoptera, Coccinellidae: Sevenepotted lady beetle

Coccinella vigintiquatuorpunctata - Coleoptera, Coccinellidae

Coccobius seminotus - Hymenoptera, Aphelinidae

Coccophagus ceroplastae - Hymenoptera, Aphelinidae

Coccus hesperidum - Hemiptera, Coccidae: Soft brown scale

Coccus marsupialis - Hemiptera, Coccidae

Coccus perlatus - Hemiptera, Coccidae

Coccus viridis - Hemiptera, Coccidae: Geen scale

Coelioxys octodentata - Hymenoptera, Megachilidae

Coeloides filiformis - Hymenoptera, Braconidae

Coeloides melanotus - Hymenoptera, Braconidae

Coelomera lanio - Coleoptera, Chrysomelidae

Coleophora laricella - Lepidoptera, Coleophoridae: Larch casebearer or larch leaf miner

Coleophora malivorella - Lepidoptera, Coleophoridae: Pistol case bearer

Coleophora pruniella - Lepidoptera, Coleophoridae

Coleotechnites starki - Lepidoptera, Gelechiidae: Northern lodgepole needleminer

Colias lesbian - Lepidoptera, Pieridae

Coloradia pandora - Lepidoptera, Saturniidae: Pandora moth

Compsus auricephalus - Coleoptera, Curculionidae: Golden headed weevil

Conchyloctenia punctata - Coleoptera, Chrysomelidae: Spotted tortoise beetle

Coniesta ignefusalis - Lepidoptera, Pyralidae: Millet stem borer

Conopomorpha cramerella - Lepidoptera, Gracillariidae: Cocoa pod borer or cocoa moth

Conopomorpha sinesis - Lepidoptera, Gracillariidae: Lichii fruit borer

Contarinia bromicola - Diptera, Cecidomyiidae: Bromegrass seed midge

Contarinia inouyei - Diptera, Cecidomyiidae: Japanese cedar gall midge

Contarinia pseudotsugae - Diptera, Cecidomyiidae: Douglas-fir needle midge

Contarinia sorghicola - Diptera, Cecidomyiidae: Sorghum midge

Contarinia tritici - Diptera, Cecidomyiidae

Conura bergi - Hymenoptera, Chalcididae 
Conura fortidens - Hymenoptera, Chalcididae

Copidosoma deceptor - Hymenoptera, Encyrtidae

Corcyra cephalonica - Lepidoptera, Pyralidae: Rice moth

Cotesia affinis - Hymenoptera, Braconidae

Cotesia ayerza - Hymenoptera, Braconidae

Cotesia deliadis - Hymenoptera, Braconidae

Cotesia glomerata - Hymenoptera, Braconidae: Cabbage white butterfly parasite

Cotesia kazak - Hymenoptera, Braconidae: Tomato fruit parasite

Cotesia melanoscela - Hymenoptera, Braconidae

Cotesia paphi - Hymenoptera, Braconidae

Cotesia plutellae - Hymenoptera, Braconidae: Diamondback moth parasite

Cotesia rubecula - Hymenoptera, Braconidae: Cabbage white butterfly parasite

Cribrolecanium andersoni - Hemiptera, Coccidae: White powdery scale

Crioceris asparagi - Coleoptera, Chrysomelidae: Asparagus beetle

Crioceris duodecimpunctata - Coleoptera, Chrysomelidae: Twelve-spotted asparagus

beetle

Cryptocephalus pini - Coleoptera, Chrysomelidae: Leaf wood beetle

Cryptonevra flavitarsis - Diptera, Chloropidae

Cryptonevra tarsata - Diptera, Chloropidae

Cydia funebrana - Lepidoptera, Tortricidae: Plum fruit moth

Cydia leucostoma - Lepidoptera, Tortricidae: Flushworm

Cylindrocopturus eatoni - Coleoptera, Curculionidae: Pine reproductive weevil

Cylindrocopturus furnissi - Coleoptera, Curculionidae: Douglas fir twig weevil

Cynips divisa - Hymenoptera, Cynipidae

Cystiphora schmidti - Diptera, Cecidomyiidae: Skeleton weed gall midge

Dacus bivittatus - Diptera, Tephritidae

Dacus ciliatus - Diptera, Tephritidae: Lesser pumpkin fly, Ethiopian fly or cucurbit fly

Dacus cucumarius - Diptera, Tephritidae

Dacus demmerezi - Diptera, Tephritidae

Dacus humeralis - Diptera, Tephritidae

Dacus punctatifrons - Diptera, Tephritidae: Tomato fruit fly

Dasineura affinis - Diptera, Cecidomyiidae: Violet leaf midge

Dasineura albovittata - Diptera, Cecidomyiidae

Dasineura amaramanjarae - Diptera, Cecidomyiidae

Dasineura balsamicola - Diptera, Cecidomyiidae: Balsalm gall midge

Dasineura brassicae - Diptera, Cecidomyiidae: Brassica pod midge

Dasineura gentneri - Diptera, Cecidomyiidae: White clover seed midge

Dasineura leguminicola - Diptera, Cecidomyiidae: Clover seed midge

Dasineura oxycoccana - Diptera, Cecidomyiidae: Blueberry gall midge or cranberry midge

Dasineura rozhkovi - Diptera, Cecidomyiidae

Dasineura urticae - Diptera, Cecidomyiidae

Datana integerrima - Lepidoptera, Notodontidae: Walnut caterpillar

Dendroctonus armandi - Coleoptera, Curculionidae

Desmia funeralis - Lepidoptera, Pyralidae: Grape leaf folder

Diacrisia scortilla - Lepidoptera, Arctiidae 
Diadegma armillatum - Hymenoptera, Ichneumonidae

Diadegma fenestrale - Hymenoptera, Ichneumonidae

Diaphorina citri - Hemiptera, Psyllidae: Asiatic citrus psyllid

Diaphania indica - Lepidoptera, Pyralidae: Cotton caterpillar, cucumber moth, pumpkin caterpillar, or melon moth

Diaphorina kopetdaghi - Lepidoptera, Pyralidae

Diaspis senegalensis - Hemiptera, Diaspididae

Dichatomus acerinus - Hymenoptera, Eulophidae

Dichoptera hyalinata - Hemiptera, Dictypharidae

Dicladispa armigera - Coleoptera, Chrysomelidae: Rice hispid

Dicraeus ingrates - Diptera, Chlopropidae

Dicraeus tibialis - Diptera, Chlopropidae

Dicrodiplosis manihoti - Diptera, Cecidomyiidae

Diopsis servillei - Diptera, Diopsidae

Diplolepis centifoliae - Hymenoptera, Cynipidae

Diplolepis eglanteriae - Hymenoptera, Cynipidae: Rose pea gall wasp

Diplolepis mayri - Hymenoptera, Cynipidae

Diplolepis spinosa - Hymenoptera, Cynipidae: Rose galling wasp

Dipogon sayi - Hymenoptera, Pompilidae

Disholcaspis quercusvirens - Hymenoptera, Cynipidae

Dolichogenidea inquisitor - Hymenoptera, Braconidae

Dolichopeza americana - Diptera, Tipulidae

Dolichopeza obscura - Diptera, Tipulidae

Dolichopeza subalbipes - Diptera, Tipulidae

Dolichopeza walleyi - Diptera, Tipulidae

Donacaula forficella - Lepidoptera, Pyralidae

Donacivola saccharella - Lepidoptera, Elachistidae

Doxocopa agathina - Lepidoptera, Nymphalidae

Drosophila flavohirta - Diptera, Drosphilidae

Dryocoetes hectographus - Coleoptera, Scolytidae

Dryocosmus kuriphilus - Hymenoptera, Cynipidae: Oriental chestnut gall wasp

Earias vittella - Lepidoptera, Noctuidae: Spotted bollworm

Ectoedemia occultella - Lepidoptera, Nepticulidae

Elasmus homonae - Hymenoptera, Eulophidae

Eldana saccharina - Lepidoptera, Pyralidae: sugarcane borer

Ensina sonchi - Diptera, Tephritidae: Sonchus fly

Epilachna argus - Coleoptera, Coccinellidae: Bryony ladybird

Epilachna chrysomelina - Coleoptera, Coccinellidae: Twelve-spotted melon beettle

Epilachna indica - Coleoptera, Coccinellidae

Epilachna similes - Coleoptera, Coccinellidae

Epilachna varivestis - Coleoptera, Coccinellidae: Mexican bean beetle

Episomus kwanhsiensis - Coleoptera, Curculionidae

Eriosoma lanigerum - Hemiptera, Aphididae: Woolly apple aphid

Eriborus argenteopilosus - Hymenoptera, Ichneumonidae

Eriborus molestae - Hymenoptera, Ichneumonidae

Erosomyia mangiferae - Diptera, Cecidomyiidae 
Erynnia nitida - Diptera, Tachinidae

Etiella zinckenella - Lepidoptera, Pyralidae: Lima bean pod borer

Eueides Isabella - Lepidoptera, Nymphalidae: Isabella helioconian

Euglyptoneura robusta - Hemiptera, Psyllidae

Euphyllura phillyreae - Hemiptera, Psyllidae: Olive psyllid

Eulecanium caraganae - Hemiptera, Coccidae

Eulecanium coryli - Hemiptera, Coccidae

Eulecanium perinflatum - Hemiptera, Coccidae

Euplectrus laphygmae - Hymenoptera, Eulophidae

Euplectrus leonae - Hymenoptera, Eulophidae

Euplectrus platyhypenae - Hymenoptera, Eulophidae

Euproctis dewitzi - Lepidoptera, Lymantriidae

Eurybrachys tomentosa - Hemiptera, Eurybrachidae

Eutreta diana - Diptera, Tephritidae

Euura atra - Hymenoptera, Tenthredindae

Evania splendidula - Hymenoptera, Evaniidae

Exochomus flavipes - Coleoptera, Coccinellidae

Exochomus quadripustulatus - Coleoptera, Coccinellidae: Pine ladybird

Exorista bombycis - Diptera, Tachinidae: Uzi fly

Exorista fasciata - Diptera, Tachinidae

Exorista sorbillans - Diptera, Tachinidae

Exoteleia pinifoliella - Lepidoptera, Gelechiidae: Pine needle miner

Ferrisia virgata - Hemiptera, Pseudococcidae: Striped mealybug

Fulgoraecia tomentosa - Lepidoptera, Epipyropidae

Galerucella maculicollis - Coleoptera, Chrysomelidae

Galerucella pruinella - Coleoptera, Chrysomelidae

Galerucella viburni - Coleoptera, Chrysomelidae

Galleria mellonella - Lepidoptera, Pyralidae: Greater wax moth

Gasteroclisus auriculatus - Coleoptera, Curculionidae

Gephyraulus diplotaxis - Diptera, Cecidomyiidae

Gestronella centrolineata - Coleoptera, Chrysomelidae

Glyphodes pyloalis - Lepidoptera, Pyralidae: Mulberry pyralid

Gnorimoschema gallaesolidaginis - Lepidoptera, Gelechiidae: Goldenrod elliptical-gall

moth or goldenrod gall moth

Gonioctena olivacea - Coleoptera, Chrysomelidae: Broom leaf beetle

Goniophthalmus halli - Diptera, Tachinidae

Goniozus claripennis - Hymenoptera, Bethylidae

Goniozus montanus - Hymenoptera, Bethylidae

Grandipalpa robusta - Lepidoptera, Gelechiidae

Grapholita molesta - Lepidoptera, Tortricidae: Oriental fruit moth

Gretchena bolliana - Lepidoptera, Tortricidae: Pecan budmoth

Gyranusoidea tebygi - Hymenoptera, Encyrtidae

Bracon brevicornis - Hymenoptera, Braconidae

Halticus bractatus - Hemiptera, Miridae: Garden fleahopper

Harmonia conglobata - Coleoptera, Coccinellidae 
Helicoverpa armigera - Lepidoptera, Noctuidae: Corn ear worm, tomato grub, tobacco bidworm, cotton bollworm

Hemadas nubilipennis - Hymenoptera, Pteromalidae: Blueberry stem gall wasp

Hemiberlesia rapax - Hemiptera, Diaspididae: Greedy scale

Hemileuca oliviae - Lepidoptera, Saturniidae

Henosepilachna vigintioctomaculata - Coleoptera, Coccinellidae

Henosepilachna vigintioctopunctata - Coleoptera, Coccinellidae: Twentysix-spotted potato ladybird

Hippodamia variegate - Coleoptera, Coccinellidae: Adonis ladybird

Holocacista rivillei - Lepidoptera, Heliozelidae

Holocerina smilax - Lepidoptera, Saturniidae

Homoeocerus lucidus - Hemiptera, Coreidae

Homona coffearia - Lepidoptera, Tortricidae: Coffee tortrix

Hyblaea puera - Lepidoptera, Hyblaeidae: Teak defoliator

Hybolasioptera cerealis - Diptera, Cecidomyiidae

Hydrellia prosternalis - Diptera, Ephydridae

Hydrellia sasakii - Diptera, Ephydridae: Paddy stem maggot

Hylesinus oleiperda - Coleoptera, Scolytidae

Hylesinus orni - Coleoptera, Scolytidae

Hypera murina - Coleoptera, Curculionidae

Hypera variabilis - Coleoptera, Curculionidae: Alfalfa weevil

Hyperaspis senegalensis - Coleoptera, Coccinellidae

Hyphantria cunea - Lepidoptera, Arctiidae: Fall webworm moth

Hypolixus truncatulus - Coleoptera, Curculionidae: Amaranth weevil

Hyposoter ebeninus - Hymenoptera, Ichneumonidae

Hypsipyla grandella - Lepidoptera, Pyralidae: Mahogany shoot borer

Hypsipyla robusta - Lepidoptera, Pyralidae: Cedar tip moth

Icerya aegyptiaca - Hemiptera, Margarodidae: Egyptian fluted scale

Icerya pattersoni - Hemiptera, Margarodidae

Iconella etiellae - Hymenoptera, Braconidae

Idioscopus clypealis - Hemiptera, Cicadellidae: Mango leafhopper

Isosandalum barbatum - Diptera, Cecidomyiidae

Isosandalum noxium - Diptera, Cecidomyiidae

Isosandalum provinciale - Diptera, Cecidomyiidae

Janetiella oenophila - Diptera, Cecidomyiidae

Janetiella siskiyou - Diptera, Cecidomyiidae

Janseodes melanospila - Lepidoptera, Noctuidae

Janus abbreviatus - Hymenoptera, Cephidae: Willow shoot sawfly

Kaltenbachiola strobe - Diptera, Cecidomyiidae

Keiferia lycopersicella - Lepidoptera, Gelechiidae: Tomato pinworm

Laccifer albizziae - Hemiptera, Kerriidae

Laccifer lacca - Hemiptera, Kerriidae: Lac scale

Laelia exclamationis - Lepidoptera, Lymantriidae

Larinus brevis - Coleoptera, Curculionidae

Larinus jaceae - Coleoptera, Curculionidae

Lasioptera falcate - Diptera, Cecidomyiidae 
Lasioptera rubi - Diptera, Cecidomyiidae: Blackberry gall midge

Lasioptera vernoniae - Diptera, Cecidomyiidae

Latoia viridissima - Lepidoptera, Limacodidae

Ledra aurita - Hemiptera, Cicadelliade

Leiopus nebulosus - Coleoptera, Cerambycidae

Lema cyanella - Coleoptera, Chrysomelidae

Lema planifrons - Coleoptera, Chrysomelidae

Lepidosaphes ulmi - Hemiptera, Diaspididae: Apple mussel scale

Leptophobia aripa - Lepidoptera, Pieridae: Green-eyed white or mountain white

Lestes dryas - Odonata, Lestidae: Emerald spreadwing damselfly

Lestes unguiculata - Odonata, Lestidae

Leucania loreyi - Lepidoptera, Noctuidae: Nightfeeding sugarcane armyworm

Leucopomyia alticeps - Diptera, Chamaemyiidae

Leucoptera coffeella - Lepidoptera, Lyonetiidae: Coffee leafminer

Leucoptera malifoliella - Lepidoptera, Lyonetiidae: Pear leaf blister moth or pear leaf miner

Leucoptera sinuella - Lepidoptera, Lyonetiidae

Leucoptera sphenograpta - Lepidoptera, Lyonetiidae

Liothrips floridensis - Thysanoptera, Phlaeothripidae

Liothrips setinodis - Thysanoptera, Phlaeothripidae

Lipara lucens - Diptera, Chloropidae

Lipara rufitarsis - Diptera, Chloropidae

Loboptera decipiens - Blattaria, Blatellidae

Lymantria dispar - Lepidoptera, Lymantriidae: Gypsy Moth

Lymantria obfuscate - Lepidoptera, Lymantriidae

Lyonetia clerkella - Lepidoptera, Lyonetiidae: Apple leaf miner

Macrocentrus homonae - Hymenoptera, Braconidae

Macrocentrus thoracicus - Hymenoptera, Braconidae

Magdalis aenescens - Coleoptera, Curculionidae: Bronze appletree weevil

Malacosoma americanum - Lepidoptera, Lasiocampidae: Eastern tent caterpillar

Malacosoma disstria - Lepidoptera, Lasiocampidae: Forest tent caterpillar

Malata mitis - Coleoptera, Coccinellidae

Mallochia pyralidis - Hymenoptera, Ichneumonidae

Manduca sexta - Lepidoptera, Sphingidae: Tobacco horn worm

Maruca vitrata - Lepidoptera, Pyralidae: Bean podborer, soybean pod borer or legume pod borer

Masakimyia pustulae - Diptera, Cecidomyiidae: Euonymus gall midge

Massalongia betulifolia - Diptera, Cecidomyiidae

Massalongia rubra - Diptera, Cecidomyiidae

Mastrus molestae - Hymenoptera, Ichneumonidae

Mayetiola destructor - Diptera, Cecidomyiidae: Hessian fly

Mayetiola piceae - Diptera, Cecidomyiidae: Spruce gall midge

Mayetiola thujae - Diptera, Cecidomyiidae: Western red cedar cone midge or red cedar cone midge

Mayetiola tumidosae - Diptera, Cecidomyiidae

Megachile pacifica - Hymenoptera, Megachilidae: Alfalfa leafcutting bee 
Megachile rotundata - Hymenoptera, Megachilidae: Alfalfa leafcutting bee

Megastigmus albifrons - Hymenoptera, Torymidae: Ponderosa pine seed chalcid or pine seed chalcid

Melanaspis glomerata - Hemiptera, Diaspididae

Melanophila decastigma - Coleoptera, Buprestidae

Melasoma lineatopunctatum - Coleoptera, Chrysomelidae

Menochilus sexmaculatus - Coleoptera, Coccinellidae

Menoetius coffeae - Coleoptera, Curculionidae

Meteorus versicolor - Hymenoptera, Braconidae

Methona confusa - Lepidoptera, Nymphalidae

Microterys nietneri - Hymenoptera, Encyrtidae

Mikomyia coryli - Diptera, Cecidomyiidae

Mimacraea krausei - Lepidoptera, Lycaenidae

Musca domestica - Diptera, Muscudae: House fly

Natada nararia - Lepidoptera, Limacodidae: Nettle grub, fringed nettle grub or slug caterpillar

Neaspilota alba - Diptera, Tephritidae

Nebrarctia oblique - Lepidoptera, Arctiidae

Neocryptopteryx orientalis - Hymenoptera, Ichneumonidae talis

Neodiprion lecontei - Hymenoptera, Diprionidae: Redheaded pine sawfly

Neodiprion pratti - Hymenoptera, Diprionidae: Jack pine sawfly or Virginia pine sawfly

Neodiprion sertifer-Hymenoptera, Diprionidae: European pine sawfly

Neodiprion swainei - Hymenoptera, Diprionidae: Swaine pine sawfly

Neodiprion virginiana - Hymenoptera, Diprionidae

Neolasioptera rostrata - Diptera, Cecidomyiidae

Nephantis serinopa - Lepidoptera, Cryptophasidae

Niditinea spretella - Lepidoptera, Tineidae

Nilaparvata lugens - Hemiptera, Delphacidae: Brown planthopper

Occidentalia comptulatalis - Lepidoptera, Pyralidae

Oecanthus nigricornis - Orthoptera, Gryllidae: Blackhorned tree cricket

Oecanthus pellucens - Orthoptera, Gryllidae

Oeneis melissa - Lepidoptera, Nymphalidae: Melissa arctic

Ogyris genoveva - Lepidoptera, Lycaenidae: Genoveva azure, purple azure or southern purple azure

Oiketicus geyeri - Lepidoptera, Psychidae

Oiketicus kirbyi - Lepidoptera, Psychidae

Oiketicus platensis - Lepidoptera, Psychidae

Omiodes indicate - Lepidoptera, Pyralidae

Oocassida pudibunda - Coleoptera, Chrysomelidae

Ooencyrtus pityocampae - Hymenoptera, Encyrtidae

Opisina arenosella - Lepidoptera, Oecophoridae: Coconut black-headed caterpillar

Orgyia australis postica - Lepidoptera, Lymantriidae

Orgyia pseudotsugata - Lepidoptera, Lymantriidae: Douglas-fir tussock moth

Orseolia oryzae - Diptera, Cecidomyiidae: Rice stem gall midge

Orseolia oryzivora - Diptera, Cecidomyiidae

Orthaga exvinacea - Lepidoptera, Pyralidae: Mango webworm 
Ostrinia furnacalis - Lepidoptera, Pyralidae: Asian corn borer

Oulema gallaeciana - Coleoptera, Chrysomelidae

Oulema lichenis - Coleoptera, Chrysomelidae

Oulema melanopus - Coleoptera, Chrysomelidae: Cereal leaf beetle

Oulema oryzae - Coleoptera, Chrysomelidae: Rice leaf beetle

Pachyrhabda antinoma - Lepidoptera, Oecophoridae

Palaeocimbex quadrimaculata - Hymenoptera, Cimbicidae

Palexorista laxa - Diptera, Tachinidae

Pandemis cerasana - Lepidoptera, Tortricidae: Barred fruit tree tortrix

Palpita machaeralis - Lepidoptera, Pyralidae: Teak leaf eating caterpillar

Paradiplosis abietis - Diptera, Cecidomyiidae

Paradiplosis tumifex - Diptera, Cecidomyiidae: Balsam gall midge

Parafomoria helianthemella - Lepidoptera, Nepticulidae

Paralepidosaphes tubulorum - Hemiptera, Diaspididae

Paratheresia claripalpis - Diptera, Tachinidae

Paratrioza cockerelli - Hemiptera, Psyllidae: Tomato psyllid or potato psyllid

Paratrioza maculipennis - Hemiptera, Psyllidae

Pardalaspis bremii - Diptera, Tephritidae

Pardalaspis cyanescens - Diptera, Tephritidae

Pardalaspis giffardi - Diptera, Tephritidae

Pardalaspis punctata - Diptera, Tephritidae: Cacoa fruit fly

Pardalaspis stictica - Diptera, Tephritidae

Parornix geminatella - Lepidoptera, Gracillariidae: Unspotted tentiform leafminer

Parthenolecanium corni - Hemiptera, Coccidae: European fruit lecanium

Pauropsylla trichaeta - Hemiptera, Triozidae

Pectinophora gossypiella - Lepidoptera, Gelechiidae: Pink bollworm

Pediobius foveolatus - Hymenoptera, Eulophidae: Mexican bean beetle parasitoid

Pediobius pyrgo - Hymenoptera, Eulophidae

Pegomya rubivora - Diptera, Anthomyiidae: Raspberry cane maggot

Periplaneta americana - Blattodea, Blatellidae: American cockroach

Periplaneta australasiae - Blattodea, Blatellidae: Australian cockroach

Perittia weberella - Lepidoptera, Elachistidae

Perkinsiella saccharicida - Hemiptera, Delphacidae: Sugarcane planthopper

Phanerotoma hendecasisella - Hymenoptera, Braconidae

Phenacoccus iceryoides - Hemiptera, Pseudococcidae

Phloeosinus aubei - Coleoptera, Scolytidae: Juniper batk beetle

Phthorimaea operculella - Lepidoptera: Gelechiidae: Potato tuberworm or potato tuber moth

Phycodes radiate - Lepidoptera, Brachodidae

Phyllocnistis citrella- Lepidoptera, Gracillariidae: Citrus leafminer

Phyllonorycter blancardella- Lepidoptera, Gracillariidae: Spotted tentiform leafminer

Phyllonorycter connexella

Phyllonorycter corylifoliella - Lepidoptera, Gracillariidae: Hawthorn red midget moth

Phyllonorycter saliciphaga - Lepidoptera, Gracillariidae

Phyllonorycter sorbi - Lepidoptera, Gracillariidae

Phyllonorycter spinicolella - Lepidoptera, Gracillariidae 
Physokermes piceae - Hemiptera, Coccidae: Spruce bud scale

Phytodietus fumiferanae - Hymenoptera, Ichneumonidae

Phytodietus spinipes - Hymenoptera, Ichneumonidae

Phytolyma lata - Hemiptera, Psyllidae

Phytomyza orobanchia - Diptera, Agromyzidae

Pieris rapae - Lepidoptera, Pieridae: Cabbage white

Pigeria piger - Hymenoptera, Braconidae

Pilemostoma fastuosum - Coleoptera, Chrysomelidae

Pinyonia edulicola - Diptera, Cecidomyiidae: Pinyon spindlegall midge

Pityophthorus polonicus - Coleoptera, Scolytidae

Placosternum dama - Hemiptera, Pentatomidae

Plagiodera versicolora - Coleoptera, Chrysomelidae

Planococcus citri-Hemiptera, Pseudococcidae: Citrus mealbug

Platyplectrus natadae - Hymenoptera, Eulophidae

Plecoptera reflexa - Lepidoptera, Noctuidae: Shisham defoliator

Plemeliella abietina - Diptera, Cecidomyiidae

Plesispa nipae - Coleoptera, Hispinae

Plutella xylostella - Lepidoptera, Plutellidae: Diamond back moth or cabbage moth

Poemyza incise - Diptera, Agromyzidae

Polynema needhami - Hymenoptera, Mymaridae

Prays oleae - Lepidoptera, Plutellidae: Olive kernel borer or olive moth

Pristomerus vulnerator - Hymenoptera, Ichneumonidae

Procecidochares alani - Diptera, Tephritidae: Mist flower gall fly

Procontarinia matteianna - Diptera, Cecidomyiidae

Procerata sacchariphaga - Lepidoptera, Brachodidae

Procerata venosata - Lepidoptera, Brachodidae

Prodiplosis platani - Diptera, Cecidomyiidae

Promecotheca bicolor - Coleoptera: Chrysomelidae

Promecotheca reichei - Coleoptera: Chrysomelidae: Coconut leaf mining beatle or palm

leaf mining beetle

Psectrosema indicum - Diptera, Cecidomyiidae

Psectrosema manii - Diptera, Cecidomyiidae

Psectrosema parvum - Diptera, Cecidomyiidae

Psectrosema reticulatum - Diptera, Cecidomyiidae

Pseudaletia separata - Lepidoptera, Noctuidae: Rice armyworm

Pseudanthonomus helvolus - Coleoptera, Curculionidae

Pseudococcus vastator - Hemiptera, Pseudococcidae

Psylla fatsiae - Hemiptera, Psyllidae

Psylla ilicina - Hemiptera, Psyllidae

Ptecticus tenebrifer - Diptera, Stratiomyiidae

Pterandrus anonae - Diptera, Tephritidae

Pterandrus colae - Diptera, Tephritidae

Pterandrus rosa fasciventris - Diptera, Tephritidae

Pteromalus cioni - Hymenoptera, Pteromalidae

Pulvinaria flavescens - Hemiptera, Coccidae

Pulvinaria mangiferae - Hemiptera, Coccidae: Mango soft scale 
Pulvinaria maxima - Hemiptera, Coccidae

Pulvinaria mesembryanthemi - Hemiptera, Coccidae: Ice plant scale

Pulvinaria minuta - Hemiptera, Coccidae

Pulvinaria platensis - Hemiptera, Coccidae

Pulvinaria pyriformis - Hemiptera, Coccidae Pulvinaria jacksoni

Pyralis farinalis - Lepidoptera, Pyralidae: Meal moth

Pyrilla perpusilla - Hemiptera, Lophopidae: Sugarcan planthopper

Pyrrhalta aenescens - Coleoptera, Chrysomelidae

Pyrrhalta luteola - Coleoptera, Chrysomelidae: Elm leaf beetle

Rabdophaga heterobia - Diptera, Cecidomyiidae

Rabdophaga salicisrhodoides - Diptera, Cecidomyiidae

Rabdophaga swainei - Diptera, Cecidomyiidae

Resseliella soya - Diptera, Cecidomyiidae

Resseliella theobaldi - Diptera, Cecidomyiidae: Raspberry cane midge

Rhagoletis completa - Diptera, Tephritidae: walnut husk fly

Rhagoletis fausta - Diptera, Tephritidae: Black cherry fruit fly

Rhagoletis pomonella - Diptera, Tephritidae: Apple maggot fly

Rhamphus oxyacanthae - Coleoptera, Curculionidae

Rhinocyllus conicus - Coleoptera, Curculionidae: Thistle head weevil

Rhodococcus spiraeae - Hemiptera, Coccidae

Rhodococcus turanicus - Hemiptera, Coccidae: Turanian scale

Rhopalomyia californica - Diptera, Cecidomyiidae: Groundselbush gall fly

Rhopalomyia chrysanthemi - Diptera, Cecidomyiidae: Chrysanthemum gall midge

Rhyacionia buoliana - Lepidoptera, Tortricidae: European pine shoot moth

Rhyacionia rigidana - Lepidoptera, Tortricidae: Pitch pine tip moth

Rogas plecopterae - Hymenoptera, Braconidae

Rondotia menciana - Lepidoptera, Bombycidae: Mulberry white caterpillar

Rothschildia orizaba - Lepidoptera, Saturniidae: Windowpane silkmoth

Rynchaenus alni - Coleoptera, Curculionidae

Rynchaenus fagi - Coleoptera, Curculionidae

Rynchaenus pilosus - Coleoptera, Curculionidae

Rynchaenus quercus - Coleoptera, Curculionidae: Oak flea weevil

Rynchaenus rufus - Coleoptera, Curculionidae

Rynchaenus salicis - Coleoptera, Curculionidae

Rhynocoris violentus - Hemiptera, Reduviidae

Ricania fenestrate - Hemiptera, Ricaniidae

Saccharosydne saccharivora - Hemiptera, Delphacidae

Saissetia oleae - Hemiptera, Coccidae: Black scale

Saperda inornata - Coleoptera, Cerambycidae: Poplar gall borer

Satyrium calanus falacer - Lepidoptera, Lycaenidae: Banded hairstreak

Sceliphron spirifex - Hymenoptera, Sphecidae

Schizomyia orientalis - Diptera, Cecidomyiidae

Schizonotus latus - Hymenoptera, Pteromalidae

Schematiza cordiae - Coleoptera, Chrysomelidae

Schoenobius bipunctifer - Lepidoptera, Pyralidae: Rice stem borer

Scirpophaga excerptalis - Lepidoptera, Pyralidae: White sugarcane borer 
Scirpophaga incertulas - Lepidoptera, Pyralidae: Yellow stem borer

Scirpophaga innotata - Lepidoptera, Pyralidae: White rice stemborer

Scirpophaga nivella - Lepidoptera, Pyralidae: White rice borer

Scirpophaga praelata - Lepidoptera, Pyralidae

Scolytus butovitschi - Coleoptera, Scolytidae

Scolytus dahuricus - Coleoptera, Scolytidae

Scolytus ensifer - Coleoptera, Scolytidae

Scolytus rugulosus - Coleoptera, Scolytidae: Shothole borer or fruit bark beetle

Scolytus schevyrewi - Coleoptera, Scolytidae: Banded elm bark beetle

Scrobipalpa absoluta - Lepidoptera, Gelechiidae

Sculna forda - Lepidoptera, Saturniidae

Scutellista caerulea - Hymenoptera, Pteromalidae

Scymnus soudanensis - Coleoptera, Coccinellidae

Scymnus subvillosus - Coleoptera, Coccinellidae

Segestes decoratus - Orthoptera, Tettigonidae

Sesamia calamistis - Lepidoptera, Noctuidae: African pink borer

Sesamia cretica - Lepidoptera, Noctuidae: Durra stem borer

Sesamia inferens - Lepidoptera, Noctuidae: Pink stem borer

Sesamia nonagrioides - Lepidoptera, Noctuidae: Corn stalk borer

Simmondsius pakistanensis - Coleoptera, Coccinellidae

Simplicia extinctalis - Lepidoptera, Herminiidae

Simplicia robustalis - Lepidoptera, Herminiidae

Smaragdina weise - Coleoptera, Chrysomelidae

Sogatella furcifera - Hemiptera, Delphacidae: White backed planthopper

Solierella similis - Hymenoptera, Sphecidae

Sphaerolecanium prunastri - Hemiptera, Coccidae: Frosted scale

Sphaerotrypes coimbatorensis - Coleoptera, Scolytidae

Spilonota holotephras - Lepidoptera, Tortricidae

Spodoptera exempta - Lepidoptera, Noctuidae: African armyworm

Spodoptera frugiperda - Lepidoptera, Noctuidae: Fall armyworm

Spodoptera littoralis - Lepidoptera, Noctuidae: Egyyptian cotton leafworm

Spodoptera litura - Lepidoptera, Noctuidae: Tobacco cutworm or cluster caterpillar

Spodoptera mauritia - Lepidoptera, Noctuidae: Lawn armyworm

Stenopa affinis - Diptera, Tephritidae

Stictocephala inermis - Hemiptera, Membracidae

Strymon edwardsii - Lepidoptera, Lycaenidae

Synanthedon pyri - Lepidoptera, Sesiidae: Apple bark borer

Synonycha grandis - Coleoptera, Coccinellidae

Systole albipennis - Hymenoptera, Eurytomidae: Parsnip seed wasp

Systole coriandri - Hymenoptera, Eurytomidae

Taxodiomyia cupressiananassa - Diptera, Cecidomyiidae: Cypress gall midge

Tenebrio molitor - Coleoptera, Tenebrionidae: Yellow mealworms

Terellia serratulae - Diptera, Tephritidae

Tetramoera schistaceana - Lepidoptera, Tortricidae: Sugarcane shoot borer

Tetrops praeustus - Coleoptera, Cerambycidae: Plumb beetle

Thaumetopoea pityocampa - Lepidoptera, Thaumetopoeidae: Pine procession moth 
Thaumetopoea wilkinsoni - Lepidoptera, Thaumetopoeidae

Thecodiplosis brachyntera - Diptera, Cecidiomyiidae: Needle-shortening pine gall midge

Thecla basilides - Lepidoptera, Lycaenidae: Pineapple borer

Thecla ericusa - Lepidoptera, Lycaenidae

Tischeria faunacella - Lepidoptera, Tischeriidae

Tischeria omissa - Lepidoptera, Tischeriidae

Tmolus echion - Lepidoptera, Lycaenidae: Larger lantan butterfly or red-spotted hairstreak

Tortrix viridana - Lepidoptera, Tortricidae: European oak leafroller

Trachelus tabidus - Hymenoptera, Cephidae: Black grain stem sawfly

Trathala hapaliae - Hymenoptera, Ichneumonidae

Trichoplusia ni - Lepidoptera, Noctuidae: Cabbage looper

Trioza bakeri - Hemiptera, Triozidae

Trioza erytreae - Hemiptera, Triozidae: Citrus psyllid

Trioza tremblayi - Hemiptera, Triozidae

Trioza viridula - Hemiptera, Triozidae

Trirhithrum coffeae - Diptera, Tephritidae

Trirhithrum nigrum - Diptera, Tephritidae

Tropicomyia atomella - Diptera, Agromyzidae

Trupanea dubautiae - Diptera, Tephritidae

Turanium scabrum - Coleoptera, Cerambycidae

Urophora jaceana - Diptera, Tephritidae

Vanessa carye - Lepidoptera, Nymphalidae: Western painted lady

Wachtliella rosarum - Diptera, Cecidomyiidae

Xanthopimpla stemmator - Hymenoptera, Ichneumonidae

Xyleborus morigerus - Coleoptera, Scolytidae: Dendrobium borer or black twig borer

Xyleborus morstatti - Coleoptera, Scolytidae

Xylomya cabrerae - Diptera, Xylomyidae

Xylosandrus compactus - Coleoptera, Curculionidae: Black twig borer

Xylotrechus pantherinus - Coleoptera, Cerambycidae

Yponomeuta malinella - Lepidoptera, Yponomeutidae: Apple ermine moth

\section{Hadrotrichodes}

Host:

Marmara gulosa - Lepidoptera, Gracillariidae: peelminer

\section{Subfamily Tetrastichinae not in California or Arizona}

\section{Minotetrastichus}

Host:

Achrysocharoides albiscapus - Hymenoptera, Eulophidae

Achrysocharoides splendens - Hymenoptera, Eulophidae

Caloptilia alchimiella - Lepidoptera, Gracillariidae

Chromatomyia aprilina - Diptera, Agromyzidae

Cimbex femorata - Hymenoptera, Cimbicidae: Button horn sheep wasp

Cirrospilus lyncus - Hymenoptera, Eulophidae

Coleophora laricella - Lepidoptera, Coleophoridae: Larch casebearer or larch leaf miner 
Coleophora pruniella - Lepidoptera, Coleophoridae

Coptodisca splendoriferella - Lepidoptera, Heliozelidae

Cotesia spuria - Hymenoptera, Braconidae

Diplolepis rosae - Hymenoptera, Cynipidae: Mossyrose gall wasp

Donacivola saccharella - Lepidoptera, Elachistidae

Fenusa pusilla - Hymenoptera, Tenthredinidae: Birch leafminer

Fenusa ulmi - Hymenoptera, Tenthredinidae: Elm leafminer

Gracillaria syringella - Lepidoptera, Gracillariidae: Lilac leafminer

Heterarthrus nemoratus - Hymenoptera, Tenthredinidae: Late birch edgeminer

Holocacista rivillei - Lepidoptera, Heliozelidae

Leucoptera laburnella - Lepidoptera, Lyonetiidae: Laburnum leaf miner

Leucoptera sinuella - Lepidoptera, Lyonetiidae

Lyonetia clerkella - Lepidoptera, Lyonetiidae: Apple leaf miner

Parectopa robiniella- Lepidoptera, Gracillariidae: Locust digitate leafminer

Parornix petiolella - Lepidoptera, Gracillariidae

Pediobius saulius - Hymenoptera, Eulophidae

Pholetesor circumscriptus - Hymenoptera, Braconidae

Pholetesor ornigis - Hymenoptera, Braconidae

Phyllocnistis tremulella - Lepidoptera, Gracillariidae

Phyllonorycter blancardella- Lepidoptera, Gracillariidae: Spotted tentiform leafminer

Phyllonorycter corylifoliella - Lepidoptera, Gracillariidae: Hawthorn red midget moth

Phyllonorycter crataegella - Lepidoptera Gracillariidae: apple blotch leafminer

Phyllonorycter delitella - Lepidoptera, Gracillariidae

Phyllonorycter distentella - Lepidoptera, Gracillariidae

Phyllonorycter lautella - Lepidoptera Gracillariidae

Phyllonorycter maestingella - Lepidoptera Gracillariidae

Phyllonorycter messaniella - Lepidoptera, Gracillariidae: Zellar's midget

Phyllonorycter millierella - Lepidoptera, Gracillariidae

Phyllonorycter platani - Lepidoptera, Gracillariidae

Phyllonorycter populifoliella - Lepidoptera, Gracillariidae

Phyllonorycter propinquinella - Lepidoptera, Gracillariidae: cherry blotchminer

Phyllonorycter pyrifoliella - Lepidoptera, Gracillariidae

Phyllonorycter quercifoliella - Lepidoptera, Gracillariidae

Phyllonorycter robiniella - Lepidoptera, Gracillariidae: Horse-chesnut leafminer

Phyllonorycter roboris - Lepidoptera, Gracillariidae

Phyllonorycter schreberella - Lepidoptera, Gracillariidae

Phyllonorycter spinicolella - Lepidoptera, Gracillariidae

Phyllonorycter tremulae - Lepidoptera, Gracillariidae

Phyllonorycter ulmifoliella - Lepidoptera, Gracillariidae

Pnigalio pectinicornis - Hymenoptera, Eulophidae

Rynchaenus alni - Coleoptera, Curculionidae

Rynchaenus fagi - Coleoptera, Curculionidae

Rynchaenus pallicornis - Coleoptera, Curculionidae

Rynchaenus populi - Coleoptera, Curculionidae

Rynchaenus testaceus - Coleoptera, Curculionidae

Shawiana phyllotomae - Hymenoptera, Braconidae 
Stigmella malella- Lepidoptera, Nepticulidae: Banded apple pigmy

Sympiesis sericeicornis - Hymenoptera, Eulophidae

Tischeria ekebladella - Lepidoptera, Tischeriidae

Tischeria longeciliata - Lepidoptera, Tischeriidae

\section{Tetrastichomyia}

Host:

Achatodes zeae - Lepidoptera, Noctuidae: Elder shoot borer

Acronicta megacephala - Lepidoptera, Noctuidae: Poplar grey

Compsilura concinnata - Diptera, Tachinidae

Diatraea crambidoides - Lepidoptera, Pyralidae

Epargyreus clarus - Lepidoptera, Hesperiidae: Silver-spotted skipper

Grapholita molesta - Lepidoptera, Tortricidae: Oriental fruit moth

Hyphantria cunea - Lepidoptera, Arctiidae: Fall webworm moth

Lymantria dispar - Lepidoptera, Lymantriidae: Gypsy moth

Malacosoma americanum - Lepidoptera, Lasiocampidae: Eastern tent caterpillar

Maliarpha separatella - Lepidoptera, Pyralidae: African white stemborer

Microplitis gortynae - Hymenoptera, Braconidae

Orgyia leucostigma - Lepidoptera, Lymantriidae: White-marked tussock moth

Ostrinia nubilalis - Lepidoptera, Pyralidae: European corn borer

Synanthedon exitiosa - Lepidoptera, Aegeriidae: Peachtree borer

Tachinidae - Diptera, Tachinidae

\section{Subfamily Tetrastichinae not in US}

Citrostichus

Host:

Phyllocnistis citrella - Lepidoptera, Gracillariidae: Citrus leafminer

Trioza obsolete - Hemiptera, Triozidae: Jumping plantlice

\section{Cryptastichus}

Host:

Phyllocnistis citrella- Lepidoptera, Gracillariidae: Citrus leafminer

\section{Mestocharella}

Host:

Acrocercops melanoplecta - Lepidoptera, Gracillariidae

Caloptilia javensis - Lepidoptera, Gracillariidae

Caloptilia kadsurae - Lepidoptera, Gracillariidae

Caloptilia protiella - Lepidoptera, Gracillariidae

Caloptilia theivora - Lepidoptera, Gracillariidae

Sycanus collaris - Hemiptera, Reduviidae 


\section{Literature Cited}

Amalin, D.M., P. Stansly, and J.E. Peña. 2004. Effect of Micromite ${ }^{\circledR}$ on the egg parasitoids Ceratogramma etiennei (Hymenoptera: Trichogrammatidae) and Quadrastichus haitiensis (Hymenoptera: Eulophidae). Florida Entomologist 87(2): 222-224.

Anonymous. 1960. A peel miner (Marmara salictella). Arizona Cooperative Survey, Cooperative Economic Insect Report 10(48):1100.

Askew, R., Shaw, M. 1974. An account of the Chalcidoidea (Hymenoptera) parasitizing leafmining insects of deciduous trees in Britain. Biological Journal of the Linnaean Society 6:289-335.

Atkins, E.L. 1961. Citrus Peelminer. The California Citrograph 46:367-371.

Atkins, E.L. 1971. The Citrus Peelminer more problems in the desert. The California Citrograph 56:245-246, 267.

Bertschy, C., Dorn, B. 2001.

http://www.zil.ethz.ch/research/cassava/concluded_projects/specialist_generalist_ parasitoids.

Bowers, M.D., Stamp, N.E., Collinge, S.K. 1992. Early stage of host range expansion by a specialist herbivore, Euphrydras phaeton (Nymphalidae). Ecology 73(2) 526-536.

Braun, A. F. 1909. Notes on Chamber's species of Tineina. Entomological News 20: 428-433.

Busck, A. 1906. New American Tineina. Proceedings of the Entomological Society of Washington 8: 86-99.

Busck, A. 1909. Notes on microlepidoptera with descriptions of new American species. Proceedings of the Entomological Society of Washington 11: 102.

Cates, R.G. 1980. Feeding patterns of monophagous, oligophagous, and polyphagous insect herbivores: the effect of resource abundance and plant chemistry. Oecologia 46: 22-31.

Cates, R.G. 1981. Host plant predictability and the feeding patterns of monophagous, oligophagous, and polyphagous insect herbivores. Oecologia 48:319-326.

Cates, R.G., Orians, G.H. 1975. Successional satus and the palatability of plants to generalized herbivores. Ecology 56:410-418. 
Cates, R.G., Rhoades, D. 1977. Patterns in the production of antiherbivore chemical defenses in plant communities. Bichemical Systematics and Ecology 5:185-193.

Chambers, V.T. 1875. Tineina of the Central United States. Cincinnati Quarterly Journal of Science 2: 107-108.

Clemens, J.B. 1860. Contribution to American lepidopterology. Proceedings of the Academy of Natural Sciences of Philadelphia 3(12):16.

Clemens, J. B. 1863. North American microlepidoptera. Proceedings of the Entomological Society of Philadelphia 2:6-8.

Coote, L.D, LaSalle, J., Schauff. 1997. Chapter 10. Eulophidae pp. 327-429 In Gibson, A.P., Huber, J.T, Woolley, J.B. eds., Annotated keys to the genera of neartic Chalcidoidea (Hymenoptera). RRC Research Press, Ottawa.

Cornell, H.V., Hawkins, B.A. 1993. Accumulation of native parasitoid species on introduced herbivores: a comparison of hosts as natives and hosts as invaders. The American Naturalist 141: 847-865.

Daly, H.V., Doyen, J.T., Purcell, A.H. 1998. Introduction to insect biology and diversity. Oxford University Press, Oxford. Pp. 613, 623, 628.

Davis, D. R. 1983. Gracillariidae in Check List of the Lepidoptera of America North of Mexico. E.W. Classey Ltd. and the Wedge Entomological Research Foundation, London pp. 9-11.

DeGryse, J.J. 1916. The hypermetamorphism of the lepidopterous sapfeeders. Proceedings of the Entomological Society of Washington 18(1): 164-168.

DeGryse, J.J. 1943. Notes on Marmara fasciella. Canadian Entomologist 75:40.

Doutt,R.L. 1964. Biological characteristics of entomophagous adults In DeBach, P. editor, Biological Control of Insects, Pests, and Weeds. Reinhold Publishing Corporation, New York. Pp. 145-167.

Feeny, P. 1976. Plant apparency and chemical defense In Wallace, J., Mansell, R. editors, Biochemical interactions between plants and insects. Recent Advances in Phytochemistry 10:1-40.

Finch, S.M. 2003. Ecological studies of and the foreign exploration for citrus peelminer, Marmara gulosa Guillen and Davis. Califonia Polytechnic State University.

Fitzgerald, T.D. 1973. Coexistence of three species of bark-mining Marmara (Lepidoptera: Gracillariidae) on green ash and descriptions of new species. Annals of the Entomological Society of America 66: 457-464. 
Fitzgerald, T. D. 1975. A new species of bark-mining Marmara (Lepidoptera: Gracillariidae) from douglas-fir. Annals of the Entomological Society of America 68: 545-548.

Flint, M.L., Dreistadt, S. H. 1998. Natural Enemies Handbook: the Illustrated Guide to Biological Control. University of California Press, Berkeley, pp. 64-66.

Forbes, W.T.M. 1923. Lepidoptera of New York and neighboring states. Memoir Agricultural Experimental Station Cornell University 68: 1-729.

Fraser, S.M., Lawton, J.H. 1994. Host-range expansion by British moths onto conifers. Ecological Entomology 19: 127-137.

Gates, M., W., Heraty, J.M., Schauff, M., E., Wagner, D.L., Whitfield, J.B., Wahl, D.B. 2002. Survey of the parasitic Hymenoptera on leafminers in California. Journal of Hymenoptera Reasearch 11(2) 213-270.

Godfrey, K., D.A. Mayhew, K. Daane, and D. Haines. 2003. Seasonal dynamics of the citrus peelminer in Tulare County pp. 29-32 In D. Woods, ed., Biological Control Program annual summary 2002. California Department of Food and Agriculture, Sacramento.

Grafton-Cardwell, B., and C. Reagan. 2001. Citrus peelminer-Pesticide trials. Available online: http://www.uckac.edu/citrusent/peelminerpesticides.htm.

Grafton-Cardwell, E. E., \& P. Gu. 2003. Conserving vedalia beetle, Rodolia cardinalis (Mulsant) (Coleoptera: Coccinellidae), in citrus: a continuing challenge as new insecticides gain registration. Journal of Economic Entomology. 96: 1388-1398.

Grafton-Cardwell, E.E., C. Reagan, and J. Stewart. 2003. Citrus peelminer evades chemical control. UC Plant Protection Quarterly. 13(2): 1-7.

Grafton-Cardwell, E.E., and C.A. Reagan. 2004. Citrus peelminer insecticide efficacy trials 2003. Arthropod Management Tests D10, 2004.

Grafton-Cardwell, C.A. Reagan, and J.E. McClain. 2005. Efficacy of Micromite and sulfur against citrus peelminer, 2005. Arthropod Management Tests D21, 2005.

Grafton-Cardwell, E.E. and C.A. Reagan. 2006. Efficacy of Dimilin against citrus peelminer, 2006. Submitted for Arthropod Management Tests, 2007. (Submitted).

Grafton-Cardwell, B., G. M. Montez, C. A. Reagan, R. Dunn, and Y. Ouyang. 2007. Effects of insecticides on citrus peelminer stages. Submitted for Pest Management Science. (Submitted). 
Grafton-Cardwell, E.E., K.E. Godfrey, D.H. Headrick, P.A. Mauk, and J.E. Peña. 2008. Citrus leafminer and citrus peelminer. University of California Agriculture and Natural Resources 8321.

Gudgel, Dan. 1999. Central California weather digest 1999. Available from http://www.wrh.noaa.gov/hnx/newslet/newsspring99.htm. October 2007.

Guillén, M. 1999. Bionomics of citrus peelminer, Marmara coachellae (Lepidoptera: Gracillariidae) in the Coachella Valley. Thesis of the University of California Riverside, Riverside.

Guillén, M., Heraty, J., Urbaneja, A. 2003. Fecundity and development of Cirrospilus coachellae (Hymenoptera: Eulophidae), a parasitoid of Marmara gulosa. Department of Entomology, University of California, Riverside.

Guillén, M., Davis, D.R., and Heraty, J. M. 2001. Systematics and biology of new a new species of Marmara (Lepidoptera: Gracillariidae) infesting grapefruit in the southwestern United States. Proceedings of the Entomological Society of Washington 103(3): 636-654.

Heppner, J. 1993. Citrus leafminer, Phyllocnistis citrella, in Florida (Lepidoptera; Gracillariidae: Phyllocnistinae). Tropical Lepidoptera 4: 49-64.

Heraty, J., Hawks, D. 1998. Hexamethyldisilizane- a chemical alternate for drying insects. Entomological News 109(5): 369-374.

Huffaker, C.B., Messenger, P.S. 1976. Theory and practice of biologicsl control. Academic Press. Pp.20-21,189-199, 233-248.

Ishaaya I., Z. Mendel, \& D. Blumberg. 1992. Effect of buprofezin on California red scale; Aonidiella aurantii (Maskell); in a citrus orchard. Israel Journal of Entomology. 25-26: 67-71.

Jaenike, J. 1990. Host specialization in phytophagous insects. Annual Review of Ecology and Sytematics 21:243-73.

Jutzi, C. 1998. Peel miner reaches valley. California grower: avocados, citrus, subtropicals. 22(3):33-34.

Kalmès, R., Rojas-Rousse. 2001. Frequency and viability of diplod and haploid males offsprings of mated females of solitary endoparasitoid (Diadromus pulchellus) (Ichneumonidae). Sciences de la Vie. 324(3):149-158. 
Knapp, J., Abrigo, L., Browning, H., Bullock, R., Heppner, J., Hall, D., Hoy, M., Nguyen, A., Peña, J., Stansly, P. 1995. Citrus leafminer, Phyllocnistis citrella Stainton: current status in Florda-1995. University of Florida Cooperative Extension Service. P. 35.

LaSalle, J. 1993. Parastic Hymenoptera, biological control, and biodiversity. In La Salle, J. and Gauld, I. editors, Hymenoptera and Biodiversity. CABI, Wallingford, United Kingdom, pp.197-215.

LaSalle, J., Gauld, I. 1993. Parasitic Hymenoptera: their diversity and their impact on the diversity of other organisms. In La Salle, J. and Gauld, I. editors, Hymenoptera and Biodiversity. CABI, Wallingford, United Kingdom, pp.1-26.

LaSalle, J., Peña, J. 1997. A new species of Galeopsomyia (Hymenoptera: Eulophidae): a fortuitous parasitoid of the citus leafminer, Phyllocnistis citrella (Lepidoptera: Gracillariidae). Florida Entomologist 80: 461-470.

Lockwood, S. 1933. Orange peel miner. California Agriculture Monthly Bulletin 22:343.

Mendel, Z., D. Blumberg, and I. Ishaaya. 1994. Effects of some insect growth regulators in natural enemies of scale insects (Hom: Coccoidea). Entomophaga 39: 199-209.

Neff, D. 2002. Ecological studies of citrus peelminer, Marmara gulosa Guillen and Davis, in the San Joaquin Valley. Califonia Polytechnic State University.

Noyes, J.S. 2002. Interactive catalogue of the world Chalcidoidea 2001. Compact disk. Taxapad, Vancouver, Canada.

Otto, S.P., Jarne, P. 2001. Haploids-hapless or happening. Science Magazine 292(5526):2441-2443.

Pilson, D. 1999. Plant hybrid zones and insect host range expansion. Ecology 80(2) 407-415.

Powell, J.A. 1980. Evolutioin of larval food preferences in Microlepidoptera. Annual Review of Entomology 25:133-159.

Rausher, M.D. 1982. Population differentiation in Euphydryas editha butterflies: larval adaptation to different hosts. Evolution 36:581-590.

. 1983. Ecology of host-selection behavior in phtyophagous insects. Pp. 223257 In Denno, R.F., McClure, S. eds., Variable plants and herbivores in natural and managed systems. Academic Press, New York New York, USA.

. 1993. The evolution of habitat preferences: avoidance and adaptation. 
Pp. 259-283 In K.C. Kim, editor, Evolution of insect pests: the pattern variations. Wiley, New York, New York, USA.

Reeves, E.L. 1995. Citrus peel miner problems. California Plant Pest and Disease Report 14: 14-16.

Rhoades, D., Cates,R.G. 1976. Toward a general theory of plant antiherbivore chemistry In Wallace, J., Mansell, R. editors, Recent Advances in Phytochemistry 10:168213.

Schauff, M.E., La Salle, J., Wijesekara, G.A. 1998. The genera of chalcid parasites (Hymenoptera: Chalcidoidea) of citrus leafminer, Phyllocnists citrella Stainton (Lepidoptera: Gracillariidae). Journal of Natural History 3(2):1001-1056.

Schönrogge, K., Stone, G.N., Crawley, M.J. 1995. Spatial and temporal variation in guild structure: parasitoids and inquilines of Andricus quercuscalicis (Hymenoptera: Cynipidae) in its native and alien ranges. Oikos 72: 51-60.

Scriber, J., Feeny, P. 1979. Growth of herbivorous caterpillars in relation to feeding specialization and the growth form of theirfood plants. Ecology 60:829-850.

Speidel, K.E. 2004. Laboratory and field biology of Mamara gulosa (Lepidoptera: Gracillariidae) and the release of Cirrospilus coachellae (Hymenoptera: Eulophidae) as a natural enemy for citrus peelminer in the San Joaquin Valley. California Polythechnic State University.

Thomas, C.D., Ng, D., Singer, M.C., Mallet, J.L.B., Parmesan, C., and Billington, H.L. 1987. Incorporation of European weed into diet of a North American herbivore. Evolution 41:892-901.

Thompson, J.N. 1988. Variation in preference in specificity in monophagous and oligophagous swallowtail populations. Evolution 42:118-128.

Thompson, J.N., Pellmyr, O. 1991. Evolution of oviposition behavior and host preference in Lepidoptera. Annual Review of Entomology 36:65-89.

Vanbergen, A.J., Raymond, B., Pearce, I. S.K., Watt, A.D., Hails, R.S., Hartley, S.E. 2003. Host shifting by Operophtera brumata into novel environments leads to population differentiation in life-history traits. Ecological Entomology 28: 604612.

Van Den Bosch, R., Messenger, P.S. 1973. Biological Control. Intext Education Publishers, New York and London. Pp. xi, 9-32, 49-73, 135-144.

Van Driesche, R.G., Bellows, T.S. Jr. 1996. Biological Control. Chapman \& Hall, New York. Pp 31-33. 
Varley, G. C., Gradwell, G. R. \& Hassell, M. P. 1973. Insect population ecology, an analytical approach. Blackwell Scientific Publications, Oxford.

Vercher, R., Garcia-María, F., Costa-Comelles, J., Marzal, C. 2005. The recruitments of native parasitoid species by the invading leafminer Phyllocnistis citrella (Lepidoptera: Gracillariidae) on citrus in Spain. Environmental Entomology 34(5): 1129-1138.

Vinal, S.C. 1917. Notes on the life-history of Marmara elotella Busck, a lepidopterous sap feeder in apple twigs. Journal of Economic Entomology 10(5): 488-496.

Winston, P., Bates, D. 1960. Saturated solution for the control of humidity in biological research. Ecology 41: 232-237.

Woglum, R. S. 1948. A willow pest that occasionally injures oranges. California Fruit Growers Exchange Pest Control Circular 168: 658.

Wrensch, D.L., Ebbert, M.A. 1993. Evoution and diversity of sex ratio in insects and mites. Chapman \& Hall, New York. Pp.11-13, 118-144, 402-504. 